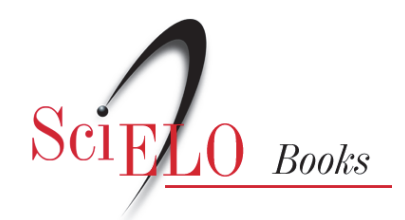

\title{
Residências terapêuticas:
}

pesquisa e prática nos processos de desinstitucionalização

\author{
Maria de Fátima de Araújo Silveira \\ Hudson Pires de O. Santos Junior \\ orgs.
}

SILVEIRA, MFA., and SANTOS JUNIOR, HPOS., orgs. Residências terapêuticas: pesquisa e prática nos processos de desinstitucionalização [online]. Campina Grande: EDUEPB, 2011. 320 p. ISBN 97885-7879-063-9. Available from SciELO Books $<\underline{\text { http://books.scielo.org }>\text {. }}$

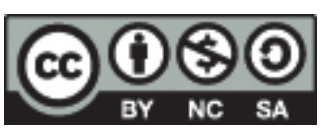

All the contents of this work, except where otherwise noted, is licensed under a Creative Commons Attribution-Non Commercial-ShareAlike 3.0 Unported.

Todo o conteúdo deste trabalho, exceto quando houver ressalva, é publicado sob a licença Creative Commons Atribuição Uso Não Comercial - Partilha nos Mesmos Termos 3.0 Não adaptada.

Todo el contenido de esta obra, excepto donde se indique lo contrario, está bajo licencia de la licencia Creative Commons Reconocimento-NoComercial-CompartirIgual 3.0 Unported. 


\section{Maria de Fátima de Araújo Silveira Hudson Pires de 0. Santos Júnior Organizadores}

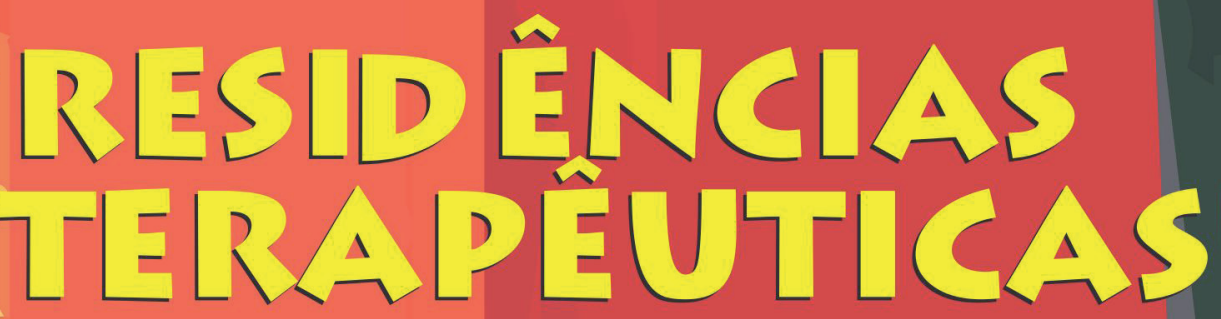

Pesquisa e prática nos processos de desinstitucionalização

\section{eduepb}




\section{RESIDÊNCIAS TERAPEUTICAS \\ Pesquisa e prática nos processos de desinstitucionalização}




\section{Universidade Estadual da Paraíba}

Profa. Marlene Alves Sousa Luna

Reitora

Prof. Aldo Bezerra Maciel

Vice-Reitor

\section{Aeduepb}

\section{Editora da Universidade Estadual da Paraíba}

\section{Diretor}

Cidoval Morais de Sousa

Coordenação de Editoração

Arão de Azevedo Souza

\section{Conselho Editorial}

Célia Marques Teles - UFBA

Dilma Maria Brito Melo Trovão - UEPB

Djane de Fátima Oliveira - UEPB

Gesinaldo Ataíde Cândido - UFCG

Joviana Quintes Avanci - FIOCRUZ

Rosilda Alves Bezerra - UEPB

Waleska Silveira Lira - UEPB

\section{Editoração Eletrônica}

Jefferson Ricardo Lima Araujo Nunes

Leonardo Ramos Araujo

\section{Capa}

Victor Maia de Paula

Comercialização e Divulgação

Júlio Cézar Gonçalves Porto

Zoraide Barbosa de Oliveira Pereira

Revisão Linguística

Elizete Amaral de Medeiros 
Maria de Fátima de Araújo Silveira

Hudson Pires de O. Santos Junior

(Orgs.)

\section{Residências Terapêuticas: pesquisa e prática nos processos de desinstitucionalização}

\section{eduepb}

Campina Grande-PB

2011 
Copyright () 2010 dos Autores.

A reprodução não-autorizada desta publicação, por qualquer meio, seja total ou parcial, constitui violação da Lei $n^{\circ}$ 9.610/98.

A EDUEPB segue o acordo ortográfico da Língua Portuguesa de 1990, em vigor no Brasil, desde 2009.

Depósito legal na Biblioteca Nacional, conforme decreto n 1.825, de 20 de dezembro de 1907.

FICHA CATALOGRÁFICA ELABORADA PELA BIBLIOTECA CENTRAL - UEPB

616.89

R432 Residências terapêuticas: pesquisa e prática nos processos de desinstitucionalização / Maria de Fátima Araujo Silveira, Hudson Pires de O. Santos Junior(Organizadores). - Campina Grande: EDUEPB, 2011.

320 p.

\section{ISBN: 978-85-7879-063-9}

1. Psiquiatria. 2. Reforma Psiquiátrica-Desistitucionalização. 3. Terapias Mentais I. SILVEIRA, Maria de Fátima Araújo. II. SANTOS, JUNIOR, Hudson Pires.

21 ed. CDD

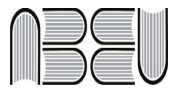

Editora filiada a ABEU

EDITORA DA UNIVERSIDADE ESTADUAL DA PARAÍBA

Rua Baraúnas, 351 - Bodocongó - Bairro Universitário - Campina Grande-PB - CEP 58429-500 Fone/Fax: (83) 3315-3381 - http://eduepb.uepb.edu.br - email: eduepb@uepb.edu.br 
Desinstitucionalizar não tem fim, não tem modelo ideal, precisa ser inventado incessantemente. Trata-se de um exercício cotidiano de reflexão e crítica sobre valores estabelecidos como naturais ou verdadeiros (...) Trata-se de um outro modo de estar na vida e, como tal, de produzir práticas em saúde. Este é o desafio que enfrentamos: resistir a tudo aquilo que mutila a vida, que nos tornam subjetividades anestesiadas, sem liberdade de criação, destituídas de singularidades.

(Alex R. Alverga; Magda D. B. Dimenstein). 


\section{Sumário}

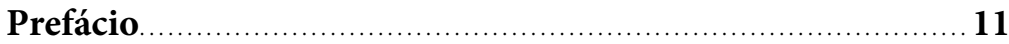

Florianita C. Braga-Campos

Apresentação ....................................................................... 15

Maria de Fátima de Araújo Silveira e Hudson Pires de O. Santos Junior

A Casa é o habitat humano

Maria de Fátima de Araújo Silveira, Hudson Pires de O. Santos Junior e Jaqueline Queiroz de Macedo

Problemas de uma casa chamada serviço:

buscando novas perspectivas de morada

para portadores de transtorno mental grave.

Juarez Pereira Furtado e Florianita C. Braga-Campos

A Utopia da Constituição do "Mapa" da Reforma Brasileira.

Simone Chandler Frichembruder e Nádia Geisa de Souza 
"E agora, o que vai ser da gente?" - Fim de um hospital psiquiátrico: relato de caso em Campina Grande-PB

Ana Angélica Pereira Souza e Maria do Carmo Eulálio

Loucos? Histórias de vida, significados do

sofrimento psíquico e (des)institucionalização

Hudson Pires de Oliveira Santos Junior, Maria de Fátima de Araújo

Silveira, Dulce Maria Rosa Gualda e Natalia Rejane Salim

Residências Terapêuticas e Reforma Psiquiátrica

em produções discursivas da população

Thelma Maria Grisi Velôso, Pedro de Oliveira Filho, Élida Dantas do Nascimento, Pauleska Asevedo Nóbrega e Roseane Barros Pinto

Vizinhanças: de correntes a redes. Entre fofocas, jardins, compras e outras formas de vizinhar.

Gabriel Binkowski, Alan Jorge, Lia Braga, Rafael Wolski,

Simone Chandler Frichembruder, Stelamaris Tinoco e Vera Resende

Com a palavra, os profissionais: estudo das representações sociais da autonomia dos moradores da "Casa Azul”.

Jaqueline Queiroz de Macedo, Maria de Fátima de Araújo Silveira e Maria do Carmo Eulálio

Uma casa, uma família: a experiência de moradia e de reconstrução dos "laços de parentesco" na residência terapêutica

Hudson Pires de Oliveira Santos Junior, Maria de Fátima de Araújo Silveira e Dulce Maria Rosa Gualda 
Uma delicada ponte entre o passado e o presente: percepções do cuidar/cuidado elaboradas pelos moradores das residências terapêuticas

Mércia Maria de Paiva Gaudêncio, Thatianna Lira Silva e Claudia Santos Martiniano

Resgatando vidas e redefinindo sonhos: experiência da Residência Terapêutica de João Pessoa - Paraíba

Ivoneide Lucena Pereira, Maria de Fátima Moura Feitosa,

Cíntia Jaqueline Bezerra Galiza e Mércia Maria dos Santos

Construindo novos espaços: tecendo uma rede de apoio para os moradores das residências terapêuticas.

Chirlaine Cristine Gonçalves, Andrea Abreu Calista, Ariedney Sâmylla de Souza Vasconcelos, Maria Cidney da Silva Soares e Stefan Yohansson Gonçalves

Casa, uma casa, minha casa: cartografia afetiva do morar 295 Mahayana Nava de Paiva Gaudêncio e Edmundo de Oliveira Gaudêncio

Organizadores 



\section{Prefácio}

Florianita C. Braga-Campos

Se levantarmos as metas prioritárias da Reforma Psiquiátrica Brasileira em:

1. Ninguém mais morará em hospital psiquiátrico; podemos dizer que Campina Grande está conseguindo manter esta meta desde 2005.

2. Garantia de acesso a uma Rede de Cuidados diuturna; dizemos que Campina Grande vem se desenvolvendo para tal, desde 2004, com lacunas na regulação da internação integral feita no hospital psiquiátrico privado conveniado ao SUS, ainda existente. Porém, é uma questão de tempo, neste processo em que a qualidade dos serviços abertos, aos poucos, gerará público que será o próprio autor da regulação e, consequente, mudança.

3. Restabelecer laços sócio-afetivos das pessoas que estiveram confinadas, durante anos; podemos afirmar, com certeza, que nenhuma experiência no Brasil atingiu, ainda, este objetivo, uma vez que tal meta será alcançada a longo prazo, o que exige uma mudança não apenas quantitativa na montagem da Rede de Cuidados em Liberdade, mas requer uma mudança maior que envolve reciprocidade de quem cuida 
e é cuidado; onde o convívio com o outro deve afetar, positivamente, qualquer dos lados; quando, lentamente, vão se desconstruindo as soluções institucionais da vida do ex-interno e de nossa vida de trabalhadores, com uma verdade especialista, que a instituição do trabalho nos impõe...

"Residências Terapêuticas: pesquisa e prática nos processos de desinstitucionalização": este título já nos diz o que este livro reúne. São reflexões sobre um dos programas mais importantes da Reforma Psiquiátrica para o processo de desinstitucionalização, que é o SERVIÇO RESIDENCIAL TERAPÊUTICO. A Portaria a esse respeito e que ilumina a abertura do Século XXI é de fevereiro do ano 2000, e surgiu do reconhecimento pelo Estado brasileiro do direito à saúde destas pessoas trancafiadas - sem terem cometido crime algum sob pretexto de tratamento. Morar em comunidade com financiamento estatal significou para estas pessoas voltarem a ser como um de nós: poder sair do seu espaço sem ser considerado fujão; rir alto, chorar, discutir e até brigar em casa, sem ser rotulado de "esquisito e/ou perigoso"; ter suas próprias coisas - móveis, roupas, comidas, lixo - e escolher como dispor delas... É tão simples como o que comer, quando beber o café ou se quer fumar... Tão simples que nós, acostumados a nem pensar sobre tais questões, às vezes, não acompanhamos o lento restabelecer à vida dos institucionalizados.

Campina Grande, em pouco tempo, acumula experiências que requer uma avaliação dia a dia de difíceis percalços para atingir as metas mais importantes e desafiadoras da Reforma Psiquiátrica. E aqui, nestas páginas, encontraremos reflexões sobre avanços e desafios a partir das pesquisas e experiências que professores e seus alunos, trabalhadores desta rede ou ainda estagiários, gestores e pesquisadores nacionais puderam trazer ao leitor.

Prefaciar um livro de temas da Saúde Mental é um grande prazer, mas uma obra que traz as pesquisas de uma Universidade, que tem como base as experiências vividas no processo da Reforma Psiquiátrica da Paraíba, principalmente em Campina Grande, é mais 
que orgulho: o coração bate pilão! A leitura dos artigos me fez trilhar a memória: com quase todas estas pessoas - Fátima Silveira, Carmita, Mércia e Edmundo Gaudêncio, professores; Mércia Santos, ex-gestora; e Chirlaine, trabalhadora da Secretaria Municipal de Campina (além de professora); Ana Angélica, que era ainda aluna de graduação... Vivemos juntos a construção inicial do que hoje trazem, nestes capítulos, resultados e grandes desafios para continuarmos essa viagem, sem perder de vista nossa utopia maior de lutar por uma sociedade sem manicômios.

Finalmente, convido-lhes para a leitura de um livro que reúne esperanças no futuro. A formação de profissionais que é apresentada pelos docentes da Universidade Estadual da Paraíba e seus alunos (e aqui quero destacar a importância desta Instituição Pública de Ensino Superior ao abraçar a mudança que ocorreu e ocorre na Saúde Mental, desde o início de um duro processo de intervenção em um dos hospícios do município de Campina), com seus estagiários, em grupos com famílias para desospitalização; bem como seus professores ajudando a seleção de novos trabalhadores para a Rede, vem, até hoje, acompanhando e ousando inovar no cuidado, ou seja, cumprindo o mais importante papel da universidade pública: produtora de conhecimento e reguladora da formação, tendo como diretriz o princípio constitucional do direito à saúde.

Vamos à leitura! 



\section{Apresentação}

Seja bem-vindo/a, a Casa é sua! Se você se arriscar a fazer a travessia destas páginas poderá descobrir veredas trilhadas por sujeitos singulares que não sentem medo e/ou vergonha de se (auto) denominar "militantes" - aqueles e aquelas que se articulam para pensar, promover e construir a saúde mental no bosque da Reforma Psiquiátrica Brasileira. Os textos apresentados, nesse cenário, configuram-se como um ativismo político e social, que permitem (re) pensar, rever, projetar, redecorar o processo de desinstitucionalização e a efetivação de um de seus dispositivos - as Residências Terapêuticas.

Gostaríamos de agradecer a todos e todas que tornaram mais esse alicerce (ou já será telhado?) possível: à Universidade Estadual da Paraíba, lar da maior parte dos habitantes da edificação, como docentes/pesquisadores/as, discentes, servidores técnico-administrativos, particularmente, aos que integram a Equipe da EDUEPB; aos autores/as, pela paciência histórica, coragem e partilha de generosidade em colocarem as mãos na água, cimento, areia, para a construção da nossa moradia; aos artistas que deram conta do projeto gráfico. Um agradecimento singular para Florianita C. Braga-Campos e Maria do Carmo Eulálio, por terem sido lanternas e fios que nos conectaram e geraram força e luz para aqui estar. Gentileza deve e precisa gerar gentileza. A todos e todas que partilham conosco a loucura pela vida, ternos e eternamente gratos somos.

Campina Grande; 05 de setembro; transição da Lua Minguante para Nova; inverno, com atraso, como a Reforma Psiquiátrica, mas como há tempos não se experimentava... Noite nublada, mas só em 
parte. Agora (23h02min), 43 moradores das residências terapêuticas desse município dormem em seus quartos, aquecidos, vestidos, alimentados/nutridos, integrados na família possível, na sociedade real! Vida longa e perene à Desinstitucionalização!

Maria de Fátima de Araújo Silveira Hudson Pires de O. Santos Junior 


\section{A Casa é o habitat humano}

Maria de Fátima de Araújo Silveira Hudson Pires de Oliveira Santos Junior Jaqueline Queiroz de Macedo

Começamos com uma indagação: qual é esse lugar que nós chamamos de lar?

Para Antônio Averlino, arquiteto italiano do medievo, mais conhecido como Filarete (RYKWERT, 2003), foi a partir da expulsão do paraíso que Adão, ao defrontar-se com a primeira chuva, estendeu as mãos cruzadas sobre o rosto, em um gesto de defesa, instituindo o primeiro abrigo, a primeira arquitetura.

Esse abrigo primordial - hupah - é simbólico, constituído de folhas, sendo, contemporaneamente, também, local de realização de casamentos judeus, portanto, de territorialização do casal e, posteriormente, da família. O hupah "era (é), em resumo, tanto uma representação do corpo de seus habitantes quanto um mapa, um modelo, e uma interpretação do mundo" (RYKWERT, 2003).

Com um olho no passado e outro no futuro, Joseph Rykwert, um dos mais respeitados historiadores da Arquitetura, aborda, em "A Casa de Adão no Paraíso" (RYKWERT, 2003), as referências arquetípicas do homem com o seu abrigo e, a partir daí, o lugar da arquitetura na formação cultural da sociedade humana. Em sua investigação, o autor recorre à antropologia, em um minucioso processo 
de relações entre fatores identitários e produção arquitetônica ao longo dos séculos. Para compreendê-los em seu devir temporal, o historiador recorre a múltiplas vias: o Livro Santo e outros escritos sagrados, ritos, obras de arquitetura e práticas construtivas. A observação dos ritos é um distintivo do autor, que não distingue entre os dois leitos, entrevendo continuidades, permanências de posturas, de aspirações que dissipam os limites estanques entre Razão e Mito.

Ao abordar as origens da arquitetura - ou da cabana primitiva um projeto arquitetural para o futuro e as formas de renovação de sua linguagem, Rykwert destaca que não basta o esquadrinhamento da primeira casa como aparato conceitual. É salutar, lembra o historiador, abeberar-se noutra fonte, anterior, onde se "rememorava a sua forma e natureza mediante cerimônias e ritos de povos que, todavia, uns ainda chamam de primitivos" (RYKWERT, 2003).

Ao adentrar no terreno das referências teóricas sobre a casa, inúmeras possibilidades se avizinham no horizonte, devido, entre outros motivos, ao fato de que cada civilização ou período histórico ter a sua forma particular de construção, entretanto, possuindo características comuns: como a de ser um abrigo, ter solidez para garantir resistência a agressões, ser espaço de conforto e intimidade.

O tratado mais antigo sobre a arquitetura da cidade e suas edificações é de autoria de Vitrúvio, arquiteto romano, que na Antiguidade Clássica escreveu De Architectura Libri Decem, a única obra de arquitetura do mundo antigo e a principal fonte sobre a Antiguidade Clássica, composta por dez livros. Neles, o autor apresenta Roma como a cidade ideal, modelo que utiliza para propor a cidade "Vitruviana", cuja ênfase é a disposição da trama viária. Por admirar a cidade, centro do poder imperial, Vitrúvio apresenta preocupação com as estruturas defensivas e questões de segurança, estabelecendo uma divisão na diversidade de construções e diferenciações entre os homens: 
$\mathrm{O}$ ato de construir é dividido em duas partes, sendo a primeira a construção de cidades fortificadas e de obras para o uso geral em locais públicos; e a segunda, a construção de edifícios para indivíduos privados. Os edifícios públicos são divididos em três classes: para defesa, religião e propósitos utilitários. Aqueles que se referem à defesa são o arranjo das muralhas, torres, pontes, portões e inventos permanentes para a resistência contra ataques hostis; os relativos à religião são altares e templos erguidos aos deuses imortais; e os que dizem respeito à utilidade são a provisão de locais de encontro para uso público, tais como portos, mercados, colunatas, termas e todos os outros arranjos similares em locais públicos. Vitrúvio acrescenta, então, que "tudo isto deve ser construído com devida referência à durabilidade (firmitas), conveniência (utilitas) e beleza (venustas)" (RYKWERT, 2003 ).

Esse antigo arquiteto aconselha que as construções devem ter em vista a divisão de classes que compõem a república e as colônias: "um segundo estágio em economia é alcançado quando temos que conceber os diferentes tipos de moradias adequados para os proprietários de casas comuns, para os de grande riqueza, ou para a alta posição de homem de estado". Fazendo de sua voz, o registro de ideias de sua classe, ainda assim, ressalta que é importante que haja "casas para toda e cada classe". Embora concedendo importância secundária, Vitrúvio recomenda que se pode e se deve adornar a cidade com monumentos esplêndidos, porém tendo como valor ideal o Estado romano (RYKWERT, 2003 ).

Apesar de única, durante todo o período da Idade Média, a obra de Vitrúvio foi pouco utilizada, sendo retomada, no Renascimento, devido às buscas por inovações defensivas, disparadas pela introdução da pólvora na artilharia. 
O principal arquiteto a se apropriar das ideias contidas na obra vitruviana foi o italiano Leon Battista Alberti, que publicou De Re Aedificatoria, estruturada, também, em dez livros, imprimindo uma visão renascentista de um ideal de cidade. Nesta obra, o autor propõe, e ratifica, a construção de edifícios em tipologia determinada pela estratificação social, quando afirma: “...escolher-se-ão poucos indivíduos na comunidade inteira, alguns dos quais distinguem-se por conhecimento, sabedoria, engenho, outros por experiência e prática das coisas, outros, enfim, por riqueza e abundância nos bens de fortuna" (SOUSA, 2008).

Alberti também discorre sobre os elementos de que se necessitam para formar a cidade, a saber: muralhas, fortes, ruas, pontes, esgotos e portos. Suas apreciações possuem sempre um valor prático, explicitam uma téchne para a construção da cidade. Na sua obra, pensa a configuração da cidade como reflexo da estrutura social, juntamente com uma série de considerações práticas, funcionais e higiênicas. $\mathrm{O}$ Livro X é um tratado de hidráulica, por exemplo.

Tanto Vitrúvio quanto Alberti vão descrever princípios tendo em vista um modelo de cidade ideal. "Os tratados de arquitetura concorrem em larga medida para a constituição e difusão da doutrina da cidade (...). A fonte primeira continua sendo o Tratado de Vitrúvio, que já conhecido na Idade Média, tornou-se o texto básico para os tratadistas de arquitetura (...)" (SOUSA, 2008)..

No rastro dessa obra, vão surgir os Tratados de Antonio Averlino ditto il Filarete (1460), Francesco di Giorgio Martini (1482) e Leonardo da Vinci (1485). Tal fato reforça a importância da obra geminal de Vitrúvio. 


\section{A casa não é apenas uma casa - em busca do abrigo}

Se a geografia, a arquitetura e a etnografia descrevem os mais diversos tipos de habitação, a fenomenologia procura revelar a "função original do habitar" e compreender a semente da "felicidade central, segura, imediata", descrita por Bachelard (2008), pois "todo o espaço realmente habitado traz a essência da noção de casa (...) e a casa é o nosso canto do mundo, o nosso primeiro universo".

A função primordial e simbólica da casa é abrigar e proteger, pois o homem só pode ser verdadeiramente homem quando tem um lar, uma casa.

A casa é uma das maiores forças de integração para os pensamentos, as lembranças e os sonhos do homem. Nessa integração, o princípio de ligação é o devaneio. (...) Sem ela, o homem seria um ser disperso. Ela mantém o homem através das tempestades do céu e das tempestades da vida. É corpo e é alma. É o primeiro mundo do ser humano. Antes de ser "jogado no mundo" (...) O homem é colocado no berço da casa (BACHELARD, 2008).

Para esse autor, a casa, através da sua representação simbólica, possibilita ao homem um enraizamento mais profundo na vida, constituindo-se como um elemento de estabilidade, sendo uma das maiores força de integração na vida do sujeito, pois a casa abriga o devaneio, protege o sonhador, permitindo-o sonhar em paz, pois em seu interior se encontram os "espaços felizes". Assim, "habitar não significa estar abandonado em qualquer lugar de um mundo hostil; mas significa estar abrigado graças ao amparo da casa". Ao se limitar aos "espaços felizes" (sótão, pavimento térreo e porão), a casa de Bachelard deixa de fora os "espaços de ódio e de combate (jardins, quintais, dependências, todas as áreas externas)" (Sousa, 2008). 
Para dar conta de tantas funções, Bachelard (2008) discorreu sobre a necessidade de a casa ter não apenas a dimensão horizontal, mas ser desenvolvida verticalmente, prolongando-se em altura e profundidade. A sua casa onírica, portanto, deve conter três andares: o pavimento térreo, o sótão e o porão, símbolo do alto e do baixo. Essa habitação é denominada de onírica, pois nela o ser humano pode se entregar ao devaneio, aos sonhos noturnos e diurnos, ao sono da fantasia. Com os devaneios, nasce a casa dos sonhos, o templo da casa natal, no qual se condensam todas as lembranças das diversas moradas habitadas e vividas pelo homem, bem como as primeiras experiências de habitar no lar paterno, que ajudam a formar a "imagem primitiva da casa" (BACHELARD, 2008).

A casa de três andares de Bachelard é uma metáfora do ser humano: id, ego e superego. Analogia semelhante foi evocada por Henri Bosco, ao descrever uma casa considerada oniricamente completa, sendo, pois, um "arquétipo sintético" e um dos esquemas verticais da psicologia humana: com o porão representando a caverna, a raiz (o inconsciente) e o sótão, o ninho (funções conscientes) (BACHELARD, 2008).

Nessa relação íntima com seus habitantes, a casa chega à vida e se torna um ser móvel e variável. Nossas impressões da casa amada mudam ao longo do tempo e dos acontecimentos que ela suscita ou acolhe (...). Espelho dos movimentos da alma, ela tem flexibilidade e se recusa a ficar essa construção de pedra imutável e parada (...). Espelho de seus habitantes, ela revela também na sua materialidade a realidade das coisas. Se habitamos, fazemo-los juntos com o mundo inteiro. $\mathrm{Na}$ sua presença ao mundo com o qual temos que conviver, a casa tem uma função sacerdotal de revelação do mistério do universo (BACHELARD, 2008). 
Discorrendo sobre o conceito de habitar, Heidegger (1986) afirma que o seu significado fundamental é o de ser um determinado ponto, estar enraizado nele, estar em casa. Também significa ter um âmbito fechado, acolhedor, um espaço próprio, no qual o homem se retira e se abriga do mundo exterior, ameaçador e hostil. Nesta acepção, o habitar opõe-se a uma estada casual, meramente passageira ou temporária, num determinado ponto arbitrário do espaço, ou seja, o significado fundamental é o "habitar uma casa".

Se as filosofias da existência encaravam o homem como um ser lançado num mundo arbitrário, contingente, não escolhido e absolutamente estranho, as filosofias do habitar consideram que a essência do homem é totalmente determinada a partir do habitar. Como afirma Bachelard (2008), o homem habita a sua casa antes de habitar o mundo. Para o filósofo, a casa é educativa: ela é paterna, é o berço da educação. Isto quer dizer que a casa, além de dispensar interiormente calor, comodidade, repouso, tranquilidade, afeto, serenidade e acolhimento, dá ao homem, na sua relação com o mundo exterior, firmeza e força para prevalecer contra o mundo. A casa ajuda a dizer: serei um habitante do mundo, a despeito do mundo.

\section{Contemporaneidade: que casas? quais casas? para quêe? para quem?}

Entretanto, cada vez mais, a casa tem sido, na sociedade contemporânea, para além de resposta objetiva e funcional, um sinal de status. No início do século XX, Charles Edouard Jeanneret-Gris, mais conhecido pelo pseudônimo de Le Corbusier, diante da era mecânica e mecanicista, designou a casa como "máquina para habitar", tendo obtido rápida adesão, pois, em suas palavras: "se a expressão fez sucesso, é porque ela contém o termo 'máquina', representando, com evidência, em todos os espíritos, a noção de funcionalismo, de rendimento, de trabalho e produção", fundamental para o Sistema Capitalista. 
Le Corbusier (1986) vai estabelecer cinco pontos sobre os quais devem-se levar em consideração a construção da "casa máquina para habitar", quais sejam: a planta livre, que através de uma estrutura independente permite a livre locação das paredes, já que estas não mais precisam exercer a função estrutural; a fachada livre, resultante igualmente da independência da estrutura. Assim, a fachada pode ser projetada sem impedimentos; os pilotis, um sistema de pilares que elevam o prédio do chão, permitindo o trânsito por debaixo do mesmo; o terrraço jardim, para "recuperar" o solo ocupado pelo prédio, "transferindo-o" para cima do prédio na forma de um jardim; e as janelas em banda que, possibilitadas pela fachada livre, visam a permitir uma relação desimpedida com a paisagem.

O sucesso dos cinco pontos foi tal que, com o tempo, estes deixaram de ser associados apenas a Le Corbusier e se tornaram cânones da arquitetura moderna. Assim, arquitetos de países diversos adotaram os preceitos, parcial ou integralmente, em suas construções, como por exemplo, no Brasil, os projetos de Lúcio Costa e Oscar Niemeyer, entre outros, (com a consultoria de Le Corbusier), utilizando integralmente os cinco pontos arquitetônicos.

Atualmente, para além de todas as "funções” que a casa ocupa, é um dos "centros" de uma grave crise financeira internacional, provocada pela especulação imobiliária irracional, carente de visão do passado glorioso e do futuro aberto ao novo, flutuante nas bolhas das bolsas de valores, que estouraram e explodiram seus gases por todo o mundo.

Entretanto, ainda permanece a vinculação de casa com o conceito de habitar, mas ressalta-se que há muitas situações (mais do que as desejáveis), em que a rua é mais segura do que uma casa.

Há, quase (?) invisíveis para a população circundante, as centenas, milhares, milhões (?) de pessoas que se arrastam durante o dia, como zumbis, carregando seus pertences, os quais, muitas vezes, são desprezados, seja pela inutilidade para a ocasião (como mudança de 
estação, por exemplo, quando cobertores e agasalhos são abandonados ao léu), seja pela dificuldade de, além de arrastar-se, arrastar consigo sua... vida, casa (?), sua provisoriedade. Estes "vivem" e dormem em formas multifacetadas, improvisadas com papelão sob os viadutos, nas praças, nas calçadas, nos degraus, terraços e varandas de prédios públicos, envolvidos pelos mantos da caridade alheia, produtos de roubos e furtos ou rasgos de tecidos e plásticos de um passado que muitos nem lembram mais.

Se o modernismo preocupava-se com o novo, tentando-se captar sua essência, o pós-modernismo busca as rupturas.

Nesse contexto pós-moderno, podem ser observadas essas mudanças, que são de toda ordem e estão em todos os lugares. Mas, como não é possível tratar delas de modo tão amplo, pode-se tomar como objeto de análise aquilo que se chama de microcélula da sociedade, a família. Fazendo o caminho do particular para o geral, a observação da reconfiguração que sofreu a família nas últimas décadas pode ser ilustrativa de algumas das transformações operadas no "mundo pós-moderno" (...) se uma das características da lógica pós-moderna é a desconstrução, parece mesmo que a família é o exemplo mais contundente desse processo (...) as mudanças econômicas, operadas em âmbito mundial, também atuaram sobre a estrutura familiar, que não é apenas aquela instituição fundada no matrimônio, patriarcal e heterossexual. Quanto ao matrimônio, sabe-se que no mundo pós-moderno, família não é mais sinônimo de casamento, instituição civil e religiosa que representava o núcleo indissolúvel. Agora se refere à junção de sujeitos sociais que compartilham alguns interesses em comum (PACHECO, TRISOTTO, 2006). 
Quando a família, estrutura sobre a qual se alicerçaram os grupos sociais, sofre grande transformação, o seu lócus - a casa - também muda, e não só de formato ou estrutura, mas de status. Pois, antes a casa era elo de ligação dos familiares e símbolo sagrado da família, espaço de reuniões, comemoração de casamentos e aniversários, ponto de partida dos mortos, símbolo dos laços consanguíneos e dos valores sociais, extensão da família, sinônimo de coletivo, de reunião e de troca; agora, configura-se em espaços individuais - "meu quarto, onde eu assisto ao programa que eu quero, na minha televisão ou no meu escritório, onde leio os meus e-mails" (PACHECO, TRISOTTO, 2006). Cada morador usa os espaços onde e quando quer, a seu tempo, e até as refeições são feitas nos mais diversos lugares e horários.

Também não há mais necessidade ou condição, para que se more em uma "casa", esta função pode ser desempenhada por um apartamento - forma mais valorizada - um hotel, flats, barcos, barracas de acampamentos ou barracos, talvez os mais numerosos, resultante das iniquidades sociais. Aqui, voltamos aos princípios vitruvianos e albertinianos fundamentados em valores, ali, oligárquicos:

Talvez esta evidência seja suficiente para demonstrar que alguns edifícios são apropriados para a sociedade como um todo; outros para os primeiros cidadãos [classe de maior poder aquisitivo], e ainda outros para as pessoas comuns [menor poder aquisitivo]. Novamente, entre os primeiros cidadãos, aqueles presidindo conselhos domésticos requerem edifícios diferentes daqueles para os envolvidos na execução de decisões ou aqueles engajados no acúmulo de riquezas (ALBERTI, 2002).

Aqui abrimos um pequeno parêntese para registrar outra forma de moradia: as favelas - uma "modalidade" urbanística própria do Brasil, em função, na maioria dos casos, da geopolítica e da 
concentração de renda, uma das maiores do planeta. Ali se encontram tantos tipos de moradias estruturadas em um emaranhado que tem chamado a atenção de grupos internacionais envolvidos com questões arquitetônicas e políticas públicas. Entretanto, seriam necessários inúmeros estudos para dar conta de todas as dobras de tal cenário no contexto brasileiro.

Portanto, hoje, para os que não se encaixam como detentores do poder ou acumuladores de riqueza, restam outras formas de casa, cuja construção ou montagem não segue nenhum tratado, ideal ou de preocupação urbanística, mas se definem pela posição ocupada (ou nenhuma) na sociedade pós-moderna, imprimindo uma nova trama na paisagem das cidades.

\section{Os direitos ainda não estão nas leis, as leis ainda não estão efetivadas, a questão não é meramente jurídica}

Diante do real experienciado, construído, destruído, reconstruído, reaproveitado e reciclado, emergiu a necessidade de assegurar-se, pelo menos em dispositivos jurídico-legais, a habitação como direito fundamental.

Que já estava previsto na Declaração dos Direitos Humanos, de 1948. Pela sua relevância e influência, é destaque em documentos oriundos de duas grandes conferências, no plano internacional, promovidas pela Organização das Nações Unidas (ONU). A primeira, realizada em 1976, sobre a problemática dos assentamentos (Declaração de Vancouver sobre Assentamentos Humanos - Habitat I), que reafirma o reconhecimento do direito à moradia como fundamental e de realização progressiva, com remissão expressa aos pactos internacionais anteriores; a segunda, de 1996, com sede em Istambul - Turquia, resultou na Agenda Habitat II, tida como o mais completo documento na matéria, do qual também o Brasil é signatário, onde, além do reafirmamento do direito, consta uma minuciosa 
previsão quanto ao conteúdo e extensão do direito à moradia, bem como das responsabilidades gerais e específicas dos Estados signatários para a sua realização, que voltarão a ser objeto de referência. Atualmente, mais de cinquenta Constituições reconhecem expressamente um direito fundamental à moradia.

Para além disso, sempre haveria como reconhecer um direito fundamental à moradia como decorrência do princípio da dignidade da pessoa humana (art. $1^{\circ}$, inciso III, da Constituição Federal), já que este reclama, na sua dimensão positiva, a satisfação das necessidades existenciais básicas para uma vida com dignidade, podendo servir até mesmo como fundamento direto e autônomo para o reconhecimento de direitos fundamentais não expressamente positivados, mas inequivocamente destinados à proteção da dignidade (LEVY, 2008).

No Brasil, a Constituição, no texto original, trazia, no Art. $6^{\circ}$, a seguinte redação: "são direitos sociais a educação, a saúde, o trabalho, o lazer, a segurança, a previdência social, a proteção à maternidade e à infância, a assistência aos desamparados, na forma desta Constituição". Entretanto, só com a aprovação da Emenda Constitucional 26/2000, o texto passou a vigorar da seguinte forma: "são direitos sociais a educação, a saúde, o trabalho, a moradia, o lazer, a segurança, a previdência social, a proteção à maternidade e à infância, a assistência aos desamparados, na forma desta Constituição”.

Pode, eventualmente, passar despercebida ou ser encarada como um mero detalhe a inclusão do termo moradia, neste artigo. Entretanto, foi a partir de todo um debate e muitas discussões ocorridas na Câmara dos Deputados que foi possível tal inserção. Os movimentos sociais realizaram forte pressão para que, posteriormente, fosse aprovado o Estatuto da Cidade, onde foram disparados instrumentos para o início da Reforma Urbana no país. 
Tal documento trouxe a possibilidade legal que existe atualmente de se desapropriar terrenos que não são usados para moradia e prestam-se à especulação imobiliária, além do lançamento de programas de governo para auxílio à moradia, Leis e outros instrumentos que desencadeiam significativas mudanças.

Se a questão extrapola o âmbito jurídico, faz-se necessário apontar algumas características básicas do que seja uma moradia: atender ao mínimo existencial e à dignidade da pessoa humana, sendo exequível (operacional e financeiramente) para os gestores das políticas habitacionais, pois "o direito de moradia considerado em sua dupla fundamentalidade (formal e material) é eminentemente prestacional (positivo), ou seja, reclama, ab initio, a realização de políticas públicas para a sua outorga efetiva" (LEVY, 2008). E ainda: "segurança jurídica da posse, disponibilidade de serviços e infra-estrutura, custos da moradia acessível, habitabilidade, acessibilidade e localização e adequação cultural" (SAULE JÚNIOR, 2004).

$\mathrm{O}$ direito de moradia encontra-se na base da maioria dos demais direitos fundamentais sociais assegurados pela Constituição Federal. Em outras palavras, pode-se dizer (sem risco de analogias eventualmente positivistas) que se trata da base material, física, a partir da qual vários outros direitos fundamentais podem ser exigidos utilmente pelos cidadãos (...). Partindo da afirmação de que a moradia é direito fundamental que empresta substrato físico à maioria dos direitos fundamentais sociais assegurados pela Constituição Federal, na medida em que constitui a base material a partir da qual vários outros direitos fundamentais podem ser exigidos utilmente pelos cidadãos, sendo de central importância para a ordem jurídico-urbanística a delimitação do conceito de moradia (BOHERER, CABISTANI, 2009). 
Mas, embora a Constituição Federal tenha explicitado o direito à moradia como fundamental, não lhe conferiu um conceito ou extensão precisos:

A devida compreensão do conceito de moradia é indispensável no sentido de afirmar "qual é a moradia" que atende aos desígnios do mínimo existencial. (...) A complexidade do conceito encetado inicia-se nas questões referentes à disponibilidade de recursos públicos e termina nas dificuldades impostas pela burocracia registral, passando pelos problemas decorrentes do caráter multidisciplinar da matéria e de seu inegável cunho político, sendo desnecessário referir que essa complexidade cresce na medida em que cresce o déficit habitacional das cidades. A conceituação de moradia indigna pode ser facilmente extraída dos elementos insertos nos dados do déficit habitacional qualitativo. Contudo, seu conceito inverso é bem mais tormentoso e exige um esforço interpretativo e conseqüente que leve em consideração os elementos jurídicos, sociais, culturais e financeiros ínsitos na ordem urbanística, vez que não basta à conflagrada realidade habitacional do país um conceito meramente jurídico de moradia (LEVY, 2008).

Tomando como ponto de vista o dos movimentos societários pela reforma urbana, o Estatuto da Cidade representa um importante marco no reconhecimento da importância das contradições e conflitos da problemática urbana, o que significa reconhecer a cidade real e não apenas a cidade ideal e/ou a legal. Trata-se, portanto, de um longo processo de reconhecimento de que a cidade é produzida coletivamente e que sua gestão deve ser democrática. 
A seguir, são apresentados alguns aspectos do Estatuto da Cidade e a criação de mecanismos e instrumentos que visam a torná-lo efetivo (BRASIL, 2001a):

I - A participação da sociedade como elemento fundamental para a elaboração da Política Urbana;

II - É dever do Estado assegurar o direito de morar a quem não dispõe de moradia digna, obrigando-o a conceder este direito em imóvel privado com delimitação de áreas especiais para moradia, reconhecimento do usucapião e regularização fundiária nas áreas ocupadas, parcelamento e a edificação compulsória, IPTU progressivo no tempo, operações urbanas consorciadas, transferência do direito de construir, direito de perempção.

III - O reconhecimento dos sujeitos coletivos da produção e do consumo da Cidade (...). Assim os que não eram reconhecidos como produtores da cidade, mas apenas como geradores de problemas urbanos passam a ser vistos como sujeitos coletivos da produção e do consumo e a cidade passa a ser compreendida como espaço coletivo. Os problemas deixam de ser analisados como desvios do modelo e podem ser enfrentados como decorrentes de própria dinâmica da urbanização.

Porém, o Estatuto da Cidade não resolve todos os conflitos, até pelo contrário, permite que deixem de ser ocultos, possibilitando aos diversos atores, agentes, sujeitos que explicitem suas diferenças para que a cidade, uma produção coletiva, tenha uma função social no interesse da maioria (RODRIGUES, 2009). 
De acordo com dados do Ministério das Cidades, o déficit habitacional estimado, em 2006, era de 7,935 milhões de domicílios, a maioria em áreas urbanas: 6,543 milhões. Observa-se, a partir da Pesquisa Nacional por Amostra de Domicílios (PNAD) de 2006, que uma das tendências que se consolida é a confirmação da região Sudeste como responsável pelo maior número das carências habitacionais, papel anteriormente desempenhado pela região Nordeste. Outro grave problema são os domicílios inadequados (estimados em 11, 247 milhões), que representam $24,1 \%$ das moradias urbanas.

Como inadequados são classificados os domicílios com carência de infraestrutura, com adensamento excessivo de moradores, com problemas de natureza fundiária, em alto grau de depreciação ou sem unidade sanitária domiciliar exclusiva. $\mathrm{O}$ maior fator de inadequação é a carência de infraestrutura, caracterizada pela ausência de atendimento adequado em um ou mais serviços básicos, como iluminação elétrica, rede geral de abastecimento de água, rede geral de esgotamento sanitário ou fossa séptica e coleta de lixo. Percentualmente o problema se torna mais relevante nas regiões Norte, Centro-Oeste e Nordeste, presente em mais de $40 \%$ dos seus domicílios urbanos. Acrescentam-se, ainda, a essa contabilidade, os domicílios em situação de déficit habitacional localizados em aglomerados subnormais (BRASIL, 1998).

A questão do uso do solo para a efetividade da moradia tem suscitado guerras, conflitos e disputas, o que tem demandado a implantação ou elaboração de instrumentos para dirimir dúvidas legais e garantir direitos. Surge, como enfrentamento a essa questão, entre tantos outros, o denominado bem de família. Este instituto jurídico tem sua gênese nos Estados Unidos da América, no estado do Texas, através da edição da Lei do Homestead, em 26 de janeiro de 1839. O significado da expressão Homestead reporta-se ao local do lar (home=lar; setead=local), surgida em defesa da pequena propriedade e que objetivava proteger as famílias radicadas naquela região. 
O Homestead surge em defesa da pequena propriedade, e traduzido ao português significa local do lar. O sentimento herdado da nação inglesa, de considerar a casa um castelo sagrado e de oferecer proteção ao colono ou imigrante, é a razão de existência do instituto do Homestead. A casa era um castelo protegido e sagrado em menor proporção: era o colono ou imigrante que mantinham tais castelos e, deviam ser protegidos para a própria manutenção destes. A Constituição Texana de 1836, antes da Lei do Homestead, tratava das linhas gerais do instituto, possibilitando a todo cidadão do Texas, com exceção dos negros africanos e de seus descendentes, a obtenção junto ao Governo de uma pequena porção de terras do Estado, desde que fosse chefe de família: "de agora e após esse ato, deverá ser reservado a todo cidadão ou chefe de família, nesta república, livre e independentemente do poder da escritura de fieri facias, ou outra execução, emitindo de qualquer corte de qualquer jurisdição competente, cinquenta acres de terra, ou um lote urbano incluso como local do lar dele ou dela, e suas melhorias" (AZEVEDO, 2002).

Diante disso, o bem de família é um meio de proteção familiar, garantindo-lhe um teto, uma casa de morar imune às futuras execuções, salvo exceções legais, definidas caso a caso nos ritos processuais. Ou seja, o bem de família é o nome dado ao imóvel de um casal, ou de uma entidade familiar, que, por proteção legal, não pode ser penhorado. Tal garantia pode ser instituída voluntariamente pelos cônjuges ou entidade familiar, por meio de escritura pública devidamente registrada no Registro de Imóveis, observadas as formalidades legais. 
Este dispositivo já estava previsto no Código Civil de 1916 (Lei $n^{\circ} 3.071$, arts. 70 a 73). Em 1990, foi editada a Lei 8.009/90, que em seu Art. $1^{\circ}$ dispõe: "O imóvel residencial próprio do casal, ou da entidade familiar, é impenhorável e não responderá por qualquer tipo de dívida civil, comercial, fiscal, previdenciária ou de outra natureza, contraída pelos cônjuges ou pelos pais ou filhos que sejam seus proprietários e nele residam, salvo nas hipóteses previstas nesta Lei" (BRASIL, 1990). Com a promulgação desta Lei, o instituto difundiu-se largamente, uma vez que o bem de família passou a ser legal, ou seja, "prescindindo da interveniência do proprietário do imóvel, posto que ditado pelo Estado, que passou a excluir da penhora o imóvel residencial de qualquer brasileiro, rico ou pobre, em face de execuções de qualquer espécie, salvo algumas poucas exceções" (VALLIATI, 2007).

Portanto, o bem de família é declarado inalienável pelo art. 72, do código Civil. A inalienabilidade vem estabelecida pela Lei com o propósito de salvaguardar a família do instituidor, proporcionando-lhe seguro asilo. Se os interessados ou donos do imóvel forem incapazes, o consentimento deve ser dado pelos representantes legais, por meio da nomeação de um curador especial, nos termos do art. 387, do Código Civil, se for o caso. É perante o juiz da cidade em que residem os interessados em bem de família que se deve promover seu cancelamento. Entre os interessados se acham os filhos do instituidor, que têm qualidade para se opor ao cancelamento (BRASIL, 2002).

O que vem sendo dito até o momento, tem a função de ampliar as concepções sobre a importância da moradia e do habitar para o ser humano, pois é um fato imbricado em todas as suas relações socioeconômica-culturais. 


\section{Residências Terapêuticas: emergências e contradições na territorialização da loucura no país - ainda uma alienação}

Cabe, a partir desse ponto, discorrer sobre a pretensão(?) de se pensar em moradias para os sofredores psíquicos, para isso, faremos uma viagem nos caminhos e descaminhos percorridos pela loucura, para que possamos desnaturalizar as concepções e refletir acerca das práticas que são realizadas atualmente na assistência às pessoas em sofrimento mental.

Tal ideia pauta-se na revelação de que tanto a loucura quanto os modos de responder a ela emergem de determinados contextos sociais, ou seja, a loucura é um fenômeno social e possui as marcas da sociedade em que fora criada, sendo pensada como bênção divina (Antiga Grécia), possessão demoníaca (Idade Média), até ser apreendida, no final do Século XVIII, como objeto da psiquiatria, isto é, como doença mental (FOUCAULT, 2004), dando início à época, que ficou conhecida, como período das grandes internações manicômiais, onde os hospitais psiquiátricos e asilos tinham a função de retirar, das ruas, aqueles sujeitos que trouxessem desordem social, ou seja, mendigos, prostitutas, vagabundos e "loucos" que, após serem segregados, eram submetidos a tratamentos desumanos, como eletrochoque, insulinoterapia, lobotomia e torturas, sendo esses ditos para a cura.

Então, o que predominou foi a compreensão da doença mental como o desvio das normas sociais, que quebra os padrões vigentes de comportamento sociável, razão pela qual o sujeito é rotulado como doente "louco", com o enfoque predominante da periculosidade social, da insanidade, da incapacidade para o trabalho, ou seja, os "loucos" eram (são?) considerados um impasse ao desenvolvimento econômico das cidades. 
Com o surgimento às instituições asilares, no período das grandes internações psiquiátricas, a medicina, através da figura do psiquiatra, assume um papel de anti-herói, onde, tendo como pano de fundo o discurso terapêutico, exerce sua principal tarefa: a de controle social-gessado.

Gessado sim, pois, como resultado de sua prática, cria-se o rótulo de doente mental, onde os sujeitos que são batizados com ele, deixam de fazer parte de uma classe social e econômica e assumem, de forma vitalícia, o "título de louco", de modo que, mesmo após anos e anos de tratamento no hospital psiquiátrico, entende-se que não há retorno à normalidade.

Para Pinel, precursor da prática médica psiquiátrica, os manicômios eram locais apropriados para analisar a doença mental, determinou o princípio do isolamento para os alienados e instaurou o primeiro modelo de terapêutica nesta área ao introduzir o tratamento moral, "libertando-os" para que pudessem ser descritos e classificadas suas patologias.

Curioso é observar que Pinel não elege o termo doença mental, mas alienação mental. Que significava um distúrbio no âmbito das paixões, capaz de produzir desarmonia na mente e na possibilidade objetiva do indivíduo perceber a realidade. No sentido mais comum do termo, alienado é alguém "de fora”, estrangeiro, alienígena. "Pode ainda significar estar fora da realidade, fora de si, sem o controle de suas próprias vontades e desejos. Fora do mundo, de outro mundo (no mundo da lua). Alienação, perda da razão, irracionalidade, animalidade" (AMARANTE, 2007).

Esse conceito de alienação mental nasce associado à ideia de periculosidade, contribuindo para produzir, como condição inerente a própria noção, uma atitude social de medo e discriminação para com os sujeitos identificados como tais.

Ao perceber a doença mental a partir da classificação de Pinel, como destituída de razão, o indivíduo perde o seu direito do livre- 
arbítrio e, consequentemente, da liberdade conferida pela própria Declaração dos Direitos Humanos, pela Revolução Francesa e pela base do Estado de Direito, o qual afirma que "todos têm direitos iguais perante a constituição". Desse modo, se o indivíduo não é livre, consequentemente não é cidadão (AMARANTE, 1995); além de que, para complementar, é considerado um irresponsável civil.

Nesse processo, o doente é distanciado do seu ambiente de vivência cotidiana, rompendo com os laços sociais e familiares, que poderiam ajudá-lo a se reintegrar, iniciando a chamada "carreira moral do doente mental" que culmina, na maioria das vezes, na cronificação do seu transtorno. O lugar do doente agora é uma cela hermética, na qual uma vez trancafiado, nunca mais pode sair. Simbolicamente, esta cela sempre estará ao seu redor, pois a doença mental, como identidade social, não mais permite ao ex-interno de um manicômio o retorno à comunidade como se nada houvesse ocorrido - ele sempre será o 'louco'?

Se por um lado, o surgimento da psiquiatria propõe uma finalidade terapêutica, por outro, cumpre uma função de normatização do espaço social mediante os dispositivos psiquiátricos tradicionais (hospitais psiquiátricos), ou dos modernos psicofármacos, que permitem uma outra forma de controle social das pessoas que desviam da norma, portanto, o foco central do tratamento psiquiátrico convencional é o controle social por meio do sistema hospitalocêntrico (DALMOLIN, 2006).

"Sem este asilo (...) nada poderia fazer, ele dá-me, porém, muito maior campo aos meus estudos" (ASSIS, 1995). Poder-se-ia pensar ser esta uma declaração emitida por Pinel, contudo, provém do personagem principal de um dos clássicos de Machado de Assis - "O Alienista” - publicado entre 1881 e 1882, e que trata de uma narrativa entremeada na vida do fictício médico Simão Bacamarte.

Machado é pioneiro na crítica ao saber psiquiátrico e aos manicômios no Brasil, como expresso na fala do personagem principal que, 
recém-chegado da Europa, decide, a partir de uma exigência externa e artificial, fundar um hospício para internar os loucos de sua cidade, por não lhes ser fornecida a devida atenção (ASSIS, 1995).

Na obra, o autor mostra a criação da Casa Verde pelo alienista, onde lhe seria possível juntar todos os loucos em um só local, e dedicar-se ao estudo da loucura, na tentativa de entender seu significado. Paulatinamente, vai fundamentando uma crítica à ciência como verdade inquestionável, sobre o que é o normal e a função do alienismo (futuramente a psiquiatria) como necessária à ordem pública. Chama a atenção o fato de Machado denominar o asilo de "casa" e, ainda por cima, qualificá-la com uma cor verde, indo de encontro ao que Erving Goffman (2003), posteriormente, denominou de instituições totais, caracterizadas como frias, impessoais, cuja arquitetura se reproduz em manicômios, prisões e conventos, marcados com cores neutras, impregnadas de mensagens cifradas, tintas produzidas a partir de fluidos e outras invenções de seus habitantes. Interessante, também, é perceber as semelhanças entre esse clássico da literatura nacional, com a história de Phelippe Pinel, diretor dos hospitais psiquiátricos de Bicetre e Salpêtriere, e seu trabalho no processo de construção do alienismo.

Contudo, a eficácia desse modelo hospitalocêntrico e médico/ psiquiátrico centrado começou a ser questionado efetivamente, por volta dos anos 60. As críticas apontavam para uma crise do sistema psiquiátrico, que além de não intervir na qualidade de saúde dos internos, era, segundo seus críticos, o produtor e mantenedor do adoecimento, responsável pelo alto índice de mortalidade e cronificação dessas pessoas, gerando inúmeras incapacidades sociais.

Diante deste processo, surge a figura do italiano Franco Basaglia (1991) que considerava o hospital psiquiátrico/manicômio uma experiência opressiva e trágica, um espaço rígido onde todas, ou quase todas, as dimensões da vida eram controladas por uma autoridade e, portanto, precisavam ser confrontadas entre os componentes da comunidade no cotidiano. Em decorrência dos seus pensamentos, 
cria-se o movimento de reforma psiquiátrica italiana ou "psiquiatria democrática italiana", um exemplo de sucesso a ser seguido na luta contra a reversão da assistência psiquiátrica hospitalar.

O Brasil, em particular, orientou sua reforma psiquiátrica inspirando-se na experiência italiana, de reversão dos hospitais psiquiátricos por dispositivos inseridos e articulados socialmente, com o intuito de alcançar a reinserção socioeconômica-cultural das pessoas em sofrimento mental e de re-estruturar as práticas de cuidados despendidas a essas.

O início legal da reforma, no Brasil, ocorreu com a apresentação do Projeto de Lei 3.657/89, o qual propunha a regulamentação dos direitos da pessoa com transtornos mentais e a progressiva substituição dos manicômios no país. Entretanto, foi somente depois de doze anos de tramitação pelo Congresso, que veio a aprovação, sendo transformado na Lei 10.216, em 6 de abril de 2001, a qual ficou conhecida como Lei da Reforma Psiquiátrica ou ainda Lei Paulo Delgado. Esta garante o processo de substituição progressiva dos leitos em hospitais psiquiátricos por uma rede comunitária de atenção psicossocial (BRASIL, 2001a).

Um dos maiores méritos dessa Lei é a explícita definição dos direitos da pessoa com transtornos mentais, devendo ser tratada com humildade e respeito e no interesse exclusivo de beneficiar sua saúde, visando a alcançar sua recuperação pela inserção na família, no trabalho e na comunidade; ser protegida contra qualquer forma de exploração; [...] ser tratada em ambiente terapêutico pelos meios menos invasivos possíveis; ser tratada preferencialmente, em serviços comunitários de saúde (BRASIL, 2001b). Logo, segundo o Ministério da Saúde, o momento atual de reforma psiquiátrica, no Brasil, é identificado por dois movimentos simultâneos e paralelos: a criação e a implantação de uma rede de atenção à saúde mental substitutiva e a monitorização e a redução progressiva e programada de leitos psiquiátricos existentes (BRASIL, 2005). 
Nesse contexto, a desinstitucionalização reordena as ações no campo da saúde mental a outro objeto, que é o sofredor psíquico, e não à doença. Para a execução da Reforma Psiquiátrica, edificar-se e efetivar-se na prática da não-exclusão, nos caminhos da desinstitucionalização, é preciso reconhecer o doente mental como sujeito de direitos e deveres, pressupondo mudanças culturais e subjetivas na sociedade, quebrado a visão dogmática em relação à loucura (AREJANO; PADILHA; ALBUQUERQUE, 2003).

Na luta para reversão desse panorama de atenção psiquiátrica hospitalocêntrica, a política de saúde vem se dedicando, nos últimos anos, para conseguir a efetiva desinstitucionalização e a reinserção dos sofredores psíquicos na sociedade. Para isso, tem contado com apoio integral dos serviços substitutivos, em especial, com as Residências Terapêuticas, espaço de morar e viver na comunidade, para egressos de internações manicomiais de longos períodos.

As Residências Terapêuticas ou moradias possuem a função de reduzir leitos dos hospitais psiquiátricos e superar a condição cronificante de "moradores do hospital", a que muitas pessoas foram relegadas, pois implica em alternativas de moradias para os egressos da instituição psiquiátrica, seja pelo suporte requerido para garantir sua permanência fora dela, seja pela dificuldade de reinserção familiar.

Para reforçar a ideia de que a Residência Terapêutica tem o propósito de ser a "casa" para os egressos de manicômios, a Portaria 106/2000 (BRASIL, 2004a) estabelece, no Art. $6^{\circ}$ :

Art. $6^{\circ}$ Definir que são características físico-funcionais dos Serviços Residenciais Terapêuticos em Saúde Mental:

6.1 apresentar estrutura física situada fora dos limites de unidades hospitalares gerais ou 
especializadas seguindo critérios estabelecidos pelos gestores municipais e estaduais;

6.2 existência de espaço físico que contemple de maneira mínima:

6.2.1 dimensões específicas compatíveis para abrigar um número de no máximo 08 (oito) usuários, acomodados na proporção de até 03 (três) por dormitório.

6.2.2 sala de estar com mobiliário adequado para o conforto e a boa comodidade dos usuários;

6.2.3 dormitórios devidamente equipados com cama e armário;

6.2.4 copa e cozinha para a execução das atividades domésticas com os equipamentos necessários (geladeira, fogão, filtros, armários, etc.);

6.2.5 garantia de, no mínimo, três refeições diárias, café da manhã, almoço e jantar. (BRASIL, 2004).

Porém, a admissão de um usuário na residência é o começo de um longo processo de reabilitação que deverá buscar a progressiva inclusão social do morador e sua emancipação pessoal, afinal, sua finalidade principal é a moradia, o morar e o viver na cidade (BRASIL, 2004b). E isso, a experiência tem demonstrado que não é "missão" tão simples, como a legislação enseja acontecer ou quando idealizada: "a casa é uma parte inalienável de seus moradores, ela tem a presença e a força de um membro, a sua força é, às vezes, mais poderosa que as ligações familiares que ela pode substituir" (A CASA..., 2008). 
Como relata Abitbol (1966) (referindo-se a acontecimentos importantes decorrentes de um conjunto de leis promulgadas em 1964, na Costa do Marfim, e que visavam a estabelecer códigos para a solidariedade familiar e proteção à orfandade):

As reformas não serão sem riscos. É difícil regulamentar através de leis as relações familiares, sobretudo quando isso significa uma grande mudança das instituições preexistentes. A oposição que pode provocar a intromissão do Estado em um domínio que lhe escapa totalmente, é impossível de prever as reações sociais que suscitará o novo sistema e as desordens que ele pode engendrar. (ABITBOL, 1966) [Grifos da autora].

Embora a residência seja entendida, via de regra, como sinônimo de casa, quando se refere a espaços constituídos pelo poder público ou outras instituições, tal termo designa um espaço de moradia para grupos, como exemplo, as residências universitárias. Assim, contextualizando para o cenário paraibano, já se percebe certa inadequação do termo "residência", pois na região, denomina-se o local de moradia como "casa". Outras inadequações podem ocorrer, particularmente quando a Reforma Psiquiátrica e o processo de desinstitucionalização, embora regulamentados, são implantados em um país com dimensões continentais e realidades geográficas, econômicas, culturais, religiosas, educacionais, entre tantas, produzem e reproduzem universos e experiências diversas e, por vezes, díspares.

Mas um ponto central a se destacar agora, diz respeito à condição do/a morador/a, quanto à inalienabilidade de seu novo lar. Do ponto de vista legal, a casa não é deles, uma vez que a Secretaria Municipal de Saúde loca o imóvel. Tal fato pode ocasionar o deslocamento e reterritorialização destes sujeitos, caso vença o contrato de locação e/ou o proprietário solicite o imóvel, motivado por, 
entre outros motivos, denúncias ou movimentos de interdição da Residência Terapêutica por parte da vizinhança.

Se o portador de transtorno psíquico não se enxerga na casa como dono ou proprietário, continua "alienado". O conceito de alienação é comum a vários domínios do saber:

...a condição psico-sociológica de perda da identidade individual ou coletiva decorrente de uma situação global de falta de autonomia. Encerra, portanto, uma dimensão objetiva - a realidade alienante - e a uma dimensão subjetiva - o sentimento do sujeito privado de algo que lhe é próprio (...). Em antropologia, a alienação é o estado de um povo forçado a abandonar seus valores culturais para assumir os do colonizador. Em sociologia e comunicação, discute-se a alienação que a publicidade e os meios de comunicação suscitam, dirigindo a vontade das massas, criando necessidades de consumo artificiais e desviando o interesse das pessoas para atividades passivas e não participativas. Em filosofia política, fala-se de alienação para designar a condição do trabalhador que, à semelhança de uma peça de engrenagem, integra a estrutura de uma unidade de produção sem ter nenhum poder de decisão sobre sua própria atividade nem direitos sobre o que produz (AZEVEDO, 2002).

Conjugando tais conceituações com a definição utilizada em psicologia e psiquiatria - "fala-se de alienação para designar o estado mental da pessoa cuja ligação com o mundo circundante está enfraquecida" (ALIENAÇÃO..., 2007) - podemos deduzir, então, que o sujeito em sofrimento psíquico, agora não mais o louco ou alienado, para efeito de sua inserção no novo modelo assistencial em saúde mental, continua "alienado", no que se refere à posse da casa. Como 
o passado não é algo estático e que não ficou tão-somente para traz, o imaginário social ainda o classifica como alienado e tais sujeitos o continuam a ser, no que se refere a sua moradia, pois que determinada, agora, pelos aspectos mercantil ou econômico-financeiro.

As consequências dessa “alienação” poderão se dar de várias formas e algumas são expressas em relatos do tipo: "essa não é a minha casa". Aqui, podendo-se vislumbrar a sua consciência quanto à propriedade que agora habita e/ou quanto ao seu desejo de voltar para uma casa (lar?) de onde se retirou, fugiu, foi excluído ou expulso e para onde não pode mais voltar, seja porque seus familiares não o querem ou não tenham condições de arcar com o seu cuidado, seja porque o seu adoecimento mental tem estreita relação com a convivência naquela moradia.

\section{Para onde vamos? Ainda, às perguntas... sempre!}

Tais constatações podem servir de subsídios para debates, discussões e enfrentamento de situações de crise decorrentes da mudança para uma Residência Terapêutica, bem como para a elaboração de estratégias que tragam nortes para as experiências singulares dos sujeitos neste processo. A possibilidade de fuga, de volta às ruas, retorno para uma família desestruturada e desestruturante ou para instituições psiquiátricas clássica não pode ser descartada. Uma outra questão diz respeito à constante reflexão se o processo de desinstitucionalização e o arranjo de moradia para egressos proposto pela Reforma corresponde ao real de que necessitam os sujeitos em sofrimento psíquico.

Pois, há relatos que demonstram a dinâmica relacional dos moradores na residência semelhante a uma estrutura de família, onde se encontram presentes relações de afeto, de cuidado um com outro, de proteção e até de conflito, apropriando-se da casa como sendo um espaço deles, mostrando-se "verdadeiros" donos do lar. 
Talvez, tenhamos que perguntar de novo, com Bachelar:

Através das lembranças de todas as casas em que encontramos abrigo, além de todas as casas em que já desejamos morar, podemos isolar uma essência íntima e concreta que seja uma justificativa para o valor singular que atribuímos a todas as nossas imagens de intimidade protegida? (Bachelar, 2008).

\section{Referências}

ABITBOL, E. La famille conjugale et le droit nouveau du mariage en Côte d'Ivoire. Journal of African Law, London, v. 10, n. 3, p. 141-163, 1966.

ALBERTI, L. B. De re aedificatoria. In: VITRUVIUS, P. (Org.). The ten books on architecture. New York: Dover Publications: 2002. p. 37-46.

ALIENAÇÃO. [S.l.:s.n.], 2007. Disponível em: <www.estudantedefilosofia.com.br/ conceitos/alienacao.php >. Acesso em: 15 mai. 2009.

AMARANTE, P. Saúde mental e atenção psicossocial. Rio de Janeiro: Fiocruz, 2007.

AMARANTE, P. Novos sujeitos, novos direitos: O Debate em Torno da Reforma Psiquiátrica. Cad. Saúde Públ. São Paulo, v. 11, n. 3, p. 414-94, 1995.

AREJANO, C. B.; PADILHA, M. I. C. S.; ALBUQUERQUE, G. L.

Reforma Psiquiátrica: uma analítica das relações de poder nos serviços de atenção à saúde mental. Rev. Bras. Enferm., v. 5, n. 56, p. 549-54, 2003. 
ASSIS, M. O alienista e outros contos. São Paulo: Moderna, 1995.

AZEVEDO, Á. V. Bem de Família: comentários à Lei 8.009/90. 5a. ed. São Paulo: Revista dos Tribunais, 2002.

BACHELAR, G. A poética do habitar. São Paulo: Martins Fontes, 2008.

BASAGLIA, F. A Instituição Negada. 2º ed. Rio de Janeiro: Graal; 1991.

BOHERER, C. C. F.; CABISTANI, L. H. Delimitação do conceito de moradia: o atendimento aos desígnios do "mínimo existencial" e a questão dos custos de produção habitacional em Porto Alegre. [S.l.:s.n.], 2009. Disponível em <http://www.anpm.com. br/fotos/artigos/artigo_dra_ Clarissa.doc $>$. Acesso em: 11 maio, 2009.

BRASIL. Lei de n. 10.216, de 06 abr. 2001. Dispõe sobre a proteção e os direitos das pessoas portadoras de transtornos mentais e redireciona o modelo assistencial em saúde mental. Diário Oficial da República Federativa do Brasil, Poder Executivo. Brasília (DF), 9 abr. 2001 a.

. Lei $\mathrm{n}^{\circ} 10.257$, de 10 de julho de 2001. Regulamenta os arts. $182 \mathrm{o}$ e 183o da Constituição Federal, estabelece diretrizes gerais de política urbana e dá outras providências. Diário Oficial da República Federativa do Brasil, Poder Executivo. Brasília (DF), 11 jul. 2001b.

. Lei no 10.406, de 10 de janeiro de 2002. Institui o Código Civil. Diário Oficial da República Federativa do Brasil, Poder Executivo. Brasília (DF), 11 jan. 2002. . Lei no 8.009, de 29 de março de 1990. Dispõe sobre a impenhorabilidade do bem de família. Diário Oficial da República Federativa do Brasil, Poder Executivo. Brasília (DF), 30 abr. 1990. 
. Ministério da Saúde. Legislação em Saúde Mental: 1990-2004. $5^{\circ}$ ed. Brasília: Ministério da Saúde, 2004a.

. Ministério da Saúde. Residências Terapêuticas: o que são, para que servem? Brasília: Ministério da Saúde, 2004b.

Ministério da Saúde. Reforma psiquiátrica e política de saúde mental no Brasil. Documento apresentado à Conferência Regional de Reforma dos Serviços de saúde Mental: 15 anos depois de Caracas. Brasília: OPAS/Ministério da Saúde, 2005.

. Ministério das Cidades. O déficit habitacional brasileiro: um mapeamento por unidades da federação. Rio de Janeiro: IPEA, 1998.

DALMOLIN, B. M. Esperança equilibrista: cartografias de sujeitos em sofrimento psíquico. Rio de Janeiro: Fiocruz, 2006.

FOUCAULT, M. História da loucura. 8a. ed. São Paulo: Edições Graal, 2004.

GOFFMAN, E. Manicômios, prisões e conventos. $7^{\circ}$ ed. São Paulo: Perspectiva, 2003.

HEIDEGGER, M. Batir habiter penser. In: HEIDEGGER, M. (Org.). Essais et conferences. Paris: Gallimard, 1986. p. 278-97.

Le Corbusier. Towards a New Architecture. London: Dover Publications; 1986

LEVY, D. R. Direito fundamental social à moradia digna. [S.l.:

s.n.], 2008. Disponível em: <http://www.aprodab.org.br/eventos/congresso2008/teses/danrlevy01.doc>. Acesso em: 01 jun. 2008. 
PACHECO, E; TRISOTTO, E. A nova casa: arranjos familiares pós-modernos. Uninter, v. 2, n. 20, 2006. Disponível em: <http:// www.grupouninter.com.br/revista/anteriores/index.php@edicao_ $\mathrm{id}=20 \&$ menu_id=4\&id=410>. Acesso em: 12 jan. 2009.

RODRIGUES, A. M. O Estatuto da Cidade: Reforma Urbana e Moradia. [S.l]: Associação brasileira de Geógrafos, 2009. Disponível em: <http:// www.lupa.org.br/ biblioteca/ o\%20estatuto\%20da\%20cidade, $\% 20$ reforma\%20urbana\%20e\%20moradia.pdf>. Acesso em: 23 jul. 2009.

RYKWERT, J. A casa de Adão no Paraíso. São Paulo: Perspectiva, 2003.

SAULE JÚNIOR, N. A Proteção jurídica da moradia nos assentamentos irregulares. Porto Alegre: Fabris, 2004.

SOUSA, F. J. S. Bachelard e Filosofia do Habitar. [S.l.: s.n], 2008.

Disponível em: <http://cyberself-cyberphilosophy.blogspot.com/2008/07/ bachelard-e-filosofia-do-habitar.html>. Acesso em: 20 jun. 2009. 


\section{Problemas de uma casa chamada serviço: buscando novas perspectivas de morada para portadores de transtorno mental grave}

Juarez Pereira Furtado

Florianita C. Braga-Campos

\section{Introdução}

A despeito de algumas iniciativas pontuais antecedentes (BRASIL, 1973; PALLADINI, 1987), podemos localizar no início da década de noventa do século passado as experiências pioneiras que influenciaram diretamente e ajudaram a conformar o que hoje entendemos como Serviços Residenciais Terapêuticos.

Nas cidades de Porto Alegre (LEITE; OLIVEIRA, 2004), Ribeirão Preto (GUIMARÃES; SAEKI, 2001) e Campinas (FURTADO; PACHECO, 1998; GUARIDO; BRAGA-CAMPOS, 2006) desenvolveram-se iniciativas de inserção de portadores de transtorno mental grave, moradores de asilos psiquiátricos, em espaços residenciais com a explícita intenção de superar o isolamento dos mesmos e, sobretudo, implementar alternativas de moradia para aqueles não mais aceitos pela família ou cujos laços familiares se perderam. 
Essas três experiências foram distintas entre si no que concerne aos fatores que desencadearam seu início, na organização interna e número inicial de usuários. Mas apresentaram convergência em dois aspectos essenciais: a busca de resposta concreta à situação de moradia para internos de longa data; e a utilização de formas de financiamento absolutamente determinadas pelas circunstâncias locais, já que se tratava de modalidade assistencial oficialmente inexistente no Sistema Único de Saúde (SUS).

O advento da portaria 106/2000 do Ministério da Saúde (BRASIL, 2004), oficializará a iniciativa no SUS, estabelecendo sua estrutura básica, modo de operar e de financiar. A partir daí, as pensões protegidas, lares abrigados, vilas terapêuticas, moradias extra-hospitalares e núcleo de convívio - como até então eram chamadas as diversas experiências de casas destinadas aos egressos de longa internação (SUIYAMA; ROLIM; COLVERO, 2007) - passarão a ser chamadas de 'Serviços Residenciais Terapêuticos'. Tal nomenclatura foi questionada à época, sobretudo no que concerne aos termos 'serviços' e 'terapêuticos', inseridos justamente para justificar e viabilizar sua inserção no Sistema Único de Saúde. Notemos aí que, ao menos em tese, se considera a possibilidade de que tais moradias pudessem ser abrigadas em outros setores, como o de promoção e assistência social.

Contudo, a Assistência Social, no Brasil, finalizava a década de 1990 com uma grande mudança imposta por diversos fatores, em que o principal foi a descentralização da assistência, quando " $O$ processo envolveu não somente mudanças de paradigmas, mas apontou a necessidade de construção de uma política pública assentada não mais nas bases do clientelismo, do paternalismo e da filantropia, mas na responsabilidade do Estado" (LIMA, 2003). Portanto, encontrava-se tão mergulhada na implantação do que dispunha a Lei Orgânica da Assistência Social (LOAS) e também do Estatuto da Criança e Adolescente (o ECA), o que dificultava ações intersetoriais num momento tão delicado, mas foi um investimento de futuro para as possibilidades atuais das políticas sociais que compartilhamos. 
Esta foi uma época em que se fortaleceu a desinstitucionalização como paradigmática na Reforma Psiquiátrica brasileira: "o processo de desinstitucionalização torna-se agora reconstrução da complexidade do objeto. A ênfase não é mais colocada no processo de "cura", mas no projeto de "invenção de saúde" e de "reprodução social do paciente" (ROTELLI; MAURI, 2001) e principalmente, "a desinstitucionalização mobiliza todos os atores envolvidos no sistema de ação institucional" (ROTELLI; MAURI, 2001). À medida em que, "quem de direito" cuidava da assistência social não podia nos socorrer, foi preciso que se desmontasse a lógica departamental das competências e atender a necessidade da pessoa adoecida em suas relações sociais, reconhecendo como interdisciplinar e intersetorial a execução desta política pública. Hoje, a área da saúde mental incorpora no Projeto Terapêutico Individual (PTI) do usuário questões de moradia e trabalho e com ele segue desenvolvendo ofertas que respondam às necessidades apresentadas.

A regulamentação das residências para portadores de transtorno mental grave em nosso sistema público de saúde representou importante conquista na medida em que viabilizou a expansão de uma iniciativa até então muito restrita em termos de número e de estados da federação nos quais se fazia presente. Atualmente, a despeito de problemas que atravancam sua expansão (FURTADO, 2006), existem aproximadamente 500 módulos residenciais nos quais habitam um total de 2.500 ex-moradores de hospitais psiquiátricos, em 18 estados da federação (BRASIL, 2007).

No entanto, convivem nesses espaços muito mais do que egressos de longas internações. Encontramos ali a coexistência entre a normatização, oriunda dos três níveis de gestão do SUS e dos conselhos profissionais, dentre outros, e um projeto de "casa", de espaço privativo, portanto avesso a regramentos provenientes do Estado e outras instâncias. Coabitam ali diretrizes gerais, estabelecidas nacionalmente, e as nuanças regionais, somadas ao fomento da emergência da subjetividade e da diversidade. Tais contradições 
não necessariamente inviabilizam esses serviços e nem são totalmente superáveis, constituindo mesmo a própria essência desses equipamentos.

A assunção dessa premissa - de que são contradições inerentes aos chamados SRTs - pode nos permitir avançar um pouco mais em torno da problemática ali presente. Faz-se necessário não restringirmos a análise dos SRTs à identificação ou não de características manicomiais ou 'institucionais' em seu modus operandi.

Reconhecemos o pano de fundo representado pela superação do manicômio, motivação primeira de sua existência, mas o acúmulo de tempo e experiência exige que passemos a encarar aquilo que é inexoravelmente constitutivo desses serviços e as novas questões dali surgidas, que extrapolam a díade manicômio - não manicômio. Somente a partir daí, poderíamos considerar com mais precisão o que de fato compõe a potência e fragilidade desses serviços residenciais, traçando novas e promissoras perspectivas.

Em suma, reafirmamos a ética de inclusão e busca de nova resposta às necessidades de moradias de portadores de transtorno mental grave presentes na proposição dessa forma de morada. Porém, como qualquer programa e serviço de caráter público, a iniciativa precisa ser analisada e avaliada. Para isso, é fundamental romper com a circularidade que tem caracterizado o debate em torno dessas moradias - circunscrito à busca de características que atestem se as mesmas superaram ou ainda mantém ritos institucionais ou manicomiais. Parece-nos ser possível aguçar nosso olhar para o interior daquilo que provém da própria experiência em curso no plano nacional, bem como acompanhar o que vem sendo discutido por outros colegas, no plano internacional, de modo a prosperarmos em direção ao aperfeiçoamento dessa complexa tarefa de prover moradias realmente adaptadas às distintas necessidades dos chamados doentes mentais graves. 


\section{A experiência canadense}

A experiência brasileira pode ser melhor compreendida se cotejada com iniciativas de outros países. Apesar das diferenças históricas e culturais, consideramos que a aproximação com a experiência canadense pode auxiliar na colocação em perspectiva da proposta nacional, estimulando nossas reflexões, à maneira de uma interlocução e assim possibilitando oferecer e conceber novas alternativas residenciais aos portadores de transtorno mental grave.

No Canadá, mais propriamente no estado de Quebec, o processo de desinstitucionalização psiquiátrica tem seu ponto de referência no relatório Bédard-Lazure, publicado em 1962, denunciando as condições degradantes dos internos de grandes hospitais e propondo a criação de alternativas à atenção asilar, que deveriam acolher e cuidar dos egressos em meio comunitário (TRUDEL; LESAGE, 2005), o que, evidentemente, levou à busca e implementação de estruturas residenciais.

Alguns autores abordam, de especial maneira, a experiência canadense na área (PIAT; PERREAULT; DORVIL, 2008; TRAINOR, 2004; SYLVESTRE, 2004; MORIN; ROBERT; DORVIL, 2001; TRAINOR, 1993). Para sintetizar a evolução das concepções e práticas quebequenses sobre as moradias aqui enfocadas, apoiar-nosemos em análise feita por Mercier (2004), com base em documentos ministeriais das últimas quatro décadas sobre o assunto, na província de Quebec.

Segundo Mercier (2004), os anos 60 se caracterizaram pela tensão entre a necessidade de inserção dos egressos na comunidade e a refratariedade dessa mesma comunidade em receber os ex-internos. Pequenos pavilhões e as chamadas 'famílias de acolhimento' (constituídas basicamente por casais que se dispunham a receber até nove egressos, sendo remunerados pelo Estado para isso) constituíram-se nas principais estratégias de desospitalização 
utilizadas. Frequentemente os responsáveis pelos pequenos pavilhões e famílias de acolhimento adotavam as mesmas rotinas grupais e pré-estabelecidas das instituições de origem no que concerne à higiene, alimentação e atividades, levando ao aumento da itinerância entre os usuários, que rejeitavam essas estruturas. Para a autora, "nesse período, a sociedade parece definir o papel desses alojamentos primordialmente como de proteção e não como de inserção".

Nos anos 70, visando a desenvolver habilidades e autonomia, a reabilitação torna-se a principal estratégia de reinserção. Um leque de opções com acompanhamento mais ou menos estruturado é oferecido a pessoas portando diferentes graus de capacidades e autonomia, a saber: pequenos pavilhões, família de acolhimento, casa de transição, apartamentos supervisionados, apartamentos satélites e, finalmente, alojamentos autônomos. A ideia central é oferecer meios de vida o menos restritivo possível, levando em conta e desenvolvendo as potencialidades de cada um (MERCIER, 2004).

Os anos 80 e 90 são caracterizados pela entrada em cena da associação dos organismos comunitários de saúde mental, chamados de recursos alternativos, composta por serviços não-governamentais (ONG's) e conduzida, em boa parte, por usuários. Estabelece-se aí forte oposição entre a rede pública, que oferece uma gama de serviços residenciais listados no parágrafo anterior e uma rede comunitária que defende que se privilegie a escolha dos usuários e o acesso destes ao mercado imobiliário formal ou subvencionado (MERCIER, 2004). O modelo alternativo de "casas normais com suporte modulado" - ou seja, uma residência cuja constituição receberia interferência mínima dos serviços e o morador contaria com suporte variável e flexível - surge em resposta às críticas ao modelo tradicional, que não responderia às necessidades e preferências dos usuários (PIAT; PERREAULT; DORVIL, 2008).

Finalmente, e consequente ao debate abordado no último parágrafo, temos, a partir dos anos 2000, um movimento para o acesso à moradia como direito fundamental para cada cidadão. Documentos 
oficiais do Ministério da Saúde passam a espelhar esse movimento ao apontar a necessidade de convergência do acompanhamento e suporte de intensidade variável, no plano individual, com ações intersetoriais visando ao acesso a moradias comuns, no plano estrutural.

Naturalmente, o pensamento e as ações dessas quatro décadas se interpõem e se influenciam, mas podemos destacar, nesse último estágio, a emergência de um novo paradigma, representado pela passagem da ideia de reabilitação para a noção plena de cidadania, na qual o acesso à morada (com acompanhamento modulado e flexível) deixa de ser um meio para tornar-se uma visão e projeto de sociedade (MERCIER, 2004). Ou seja, ganha plano operacional e de disputa política a ideia de que se os determinantes sociais de saúde conduzidos fora do campo médico (trabalho, renda, moradia, educação, etc.) podem ter efeitos decisivos na saúde das pessoas ditas normais, então esses mesmos fatores podem ter igual ou maior influência para aqueles cuja saúde é atravessada pelos distúrbios mentais ou, nas palavras desse mesmo autor, "é em razão desses motivos que a moradia constitui um terreno de luta por aquilo que é, no final das contas, um direito à vida" (DORVIL, 2004).

\section{Identificando alternativas na fronteira}

A experiência canadense, anteriormente apresentada, estimula-nos o pensamento ao menos em duas vias: primeiramente sobre a importância da existência do maior número possível de opções que respondam ou ao menos se aproximem à diversidade do que constitui o morar; por outro lado, a experiência citada coloca ênfase no acesso à moradia não no plano terapêutico, mas da cidadania, do direito.

Em relação a esta última, tivemos exemplo emblemático no Brasil no início dos anos noventa, quando da inserção de alguns dos antigos moradores do Hospital Estadual Santa Tereza (Ribeirão Preto, SP) 
em casas construídas pelo sistema estadual de habitação (COHAB). Poderíamos afirmar, no entanto, que a posse ou ao menos a garantia de uma casa como direito ainda está longe de se tornar uma questão para os moradores de SRTs. Talvez algum aceno nesse sentido possa ser notado, quando, no rol de razões para não deixar o hospital, os eventuais futuros moradores apontem o receio de que "mude o governo e a gente fique na rua". Ainda nesse sentido, e após terem se tornado moradores, não é incomum deles ouvirmos afirmações de que a casa não é deles, mas do hospital ou do governo.

Com relação à diversidade de opções, é inegável que as características da cultura e da administração local, somadas ao perfil do grupo que habita as casas, imprimam um tom peculiar a cada módulo residencial. Além disso, é frequente o estabelecimento de convênio entre as secretarias municipais de saúde e alguma ONG do município, com o intuito de fazer face à necessidade de agilidade e flexibilidade requerida no dia a dia das casas, impossível de serem atendidas a contento pelos ritos da administração de serviços públicos.

Em que pesem essas adaptações locais e institucionais, a portaria 106 representa forte elemento indutor do perfil técnico, administrativo e assistencial desses dispositivos. Sobretudo se considerarmos as dimensões continentais de nosso país e a grande inserção, nos serviços originários da reforma psiquiátrica, de novos trabalhadores carentes de parâmetros que venham pautar as suas práticas. Conforme discutido em outro momento, sobre a transposição das políticas de saúde mental para a prática nos novos serviços, os profissionais que militaram pelas mudanças e vivenciaram transformações institucionais e políticas do setor, provavelmente conseguem traduzir os princípios e mesmo as normas administrativas da reforma para as práticas cotidianas (ONOCKO-CAMPOS; FURTADO, 2006).

Porém, uma grande maioria representada pelos que não tiveram a oportunidade de absorver os princípios éticos com a militância e os movimentos pró-reforma, acabam se fixando em saberes produzidos 
anteriormente às mudanças e/ou às normatizações contidas nas portarias. Nesse sentido, a existência de um único tipo de moradia e financiamento soma-se à tendência dos gestores e trabalhadores em seguir as diretrizes ao pé da letra ou até mesmo tornando-as mais restritas (como atesta o frequente entendimento de que os módulos devem ter 'necessariamente' oito moradores e não "até oito" como consta na referida portaria, ou de que é obrigatório existir $24 \mathrm{~h}$ a figura do cuidador em qualquer casa).

O problema não parece ser a portaria em si, mas o fato de contarmos hoje em dia com apenas um referencial normativo técnico-assistencial que, por sua vez, é frequentemente tomado como matriz a ser reproduzida no provimento de morada para portadores de transtornos mentais graves, egressos de longas internações psiquiátricas. Coerentes com o que afirmamos no primeiro tópico, não colocamos, em questão, a legitimidade da oferta de alternativas residenciais para os egressos, mas propomos indagações sobre como realizar necessários avanços e ajustes de rotas nesse processo.

Seria tentador pensar em novas portarias, ampliando o leque de escolhas de moradas possíveis. Acreditamos, no entanto, que não se trata de editar novas normas e propor alternativas, a priori. O debate realizado por meio de lista de discussão para a reforma da portaria 106, da qual participaram 50 convidados (gestores locais, coordenadores ou assistentes diretos de SRTs) de várias regiões do país ilustra a tendência à tipologização. Foram trocadas 84 mensagens, posteriormente compiladas em um arquivo eletrônico e enviado aos integrantes da lista para validação (FURTADO, 2006; FURTADO; HOFFMANN; MARDEN, 2004). Vários temas foram debatidos virtualmente nessa lista, sendo um dos produtos finais a proposta de criação de um SRT do tipo II, voltado para internos de hospital psiquiátrico que requerem maior suporte para deixar o asilo.

Podemos nos questionar: vamos adotar a fase inicial canadense, ou seja, quando a preocupação principal foi de proteção e não de inserção? Seguramente, não, mas existem riscos desde que nossa 
portaria denomina as casas de Serviços. O que ocorre, não podemos esconder os fatos, é que a Reforma Psiquiátrica encontra-se em uma grave dificuldade: cerca de 30\% dos leitos dos hospícios são de residentes e, em sua grande maioria, idosos e/ou fisicamente dependentes. Porém, se já passamos dos 15 anos de experiências brasileiras, que acumulam não apenas resultados que apontam na direção da inserção, mas também do direito à vida (moradia e trabalho), o que nos conduziria a este tipo II? Não existem, na cultura dos humanos, a não ser nas instituições asilares, casas onde residem num mesmo lugar pessoas da mesma faixa etária, com os mesmo problemas físicos ou mentais etc. Contudo, desconstruir o paradigma da cura, da assepsia como marca dos Serviços de saúde é a parte mais difícil deste processo do cuidar de ex-confinados dos hospícios, agora à luz da vida, dos riscos da rua e dos conflitos da comunidade. E isto não se resolve através de portarias.

Evidentemente não seria possível prever todos os tipos de morada. A melhor alternativa se configuraria em normatização suficientemente restrita para permitir o acompanhamento criterioso por parte de diferentes instâncias e o financiamento dentro do SUS e ampla e permeável o suficiente para abrigar as diferentes demandas e necessidades no que concerne ao lar de portadores de transtorno mental grave: do serviço residencial ao apart-hotel.

Enfim, consideramos importante e pertinente para a discussão da portaria vigente e posterior implementação de novos parâmetros o conhecimento de experiências constituídas pelos usuários, com ou sem apoios institucionais, nos limites ou até mesmo fora do que entendemos como SRTs. Por essa razão, a aproximação e compreensão de experiências de moradias alternativas ao padrão vigente - após a passagem por algum SRT ou que até mesmo nunca utilizaram tal estrutura - pode gerar importantes subsídios para o delineamento de novos horizontes possíveis para a garantia de moradas dessa natureza na comunidade. 


\section{À guisa de conclusão}

Em estudo já citado, identificamos na dificuldade em conviver com o portador de transtorno mental grave na comunidade e em questões políticas e gerenciais os principais problemas relativos à expansão, e, portanto, ao acesso de novos usuários aos Serviços Residenciais Terapêuticos (FURTADO, 2006). No presente artigo, enfocamos não exatamente o acesso, mas a necessidade de permeabilidade da iniciativa aos muitos sentidos e meios que constituem o morar, apontando a necessidade de mais diversidade dentre as alternativas de moradia que vêm sendo oferecidas aos portadores de transtorno mental grave, de modo a contemplar as necessidades e preferências dos mesmos. Por outro lado, consideramos que é justamente dentre os atuais moradores ou, mais especialmente, dentre os usuários que saíram ou nunca entraram nos SRTs, constituindo outras formas de morar na comunidade, que poderíamos localizar as principais críticas e apontamentos que podem subsidiar a adequação da iniciativa.

É de se esperar que os atuais moradores de SRTs, se convenientemente abordados, terão muito a dizer sobre o que lhes satisfaz ou não nessas residências. Porém, consideramos que dentre aqueles que, por alguma razão, constituíram formas alternativas ao preconizado pela portaria 106, poderíamos encontrar expresso duplamente seus posicionamentos: pelo discurso e pela própria experiência estabelecida.

Por essa razão, concluímos a presente discussão apontando para a premente necessidade de realizarmos pesquisas voltadas para a identificação de como aqueles que, por alguma razão, não se enquadraram nos contornos oferecidos pelos Serviços Residenciais Terapêuticos, constituíram suas moradas. Exatamente nesse ponto, poderemos encontrar balizas para a ampliação qualitativa de ofertas pertinentes a seus usuários, bem como posicionamentos críticos a respeito da forma como vimos conduzindo a iniciativa. 
É como se buscássemos, nas fronteiras, nos limites, novas possibilidades, novos horizontes para a garantia de moradias inseridas na comunidade para portadores de transtorno mental grave, indo atrás das adaptações e modificações realizadas pelos usuários finais, tais como ocorrido com as casas inicialmente projetadas por Le Courbusier e posteriormente adaptadas por seus moradores:

Apesar dessa dificuldade de registrar os meios de criar um tipo de habitação que seja totalmente atual, as casas projetadas por Le Corbusier tiveram um destino estranho quando elas chegaram a ser habitadas por pessoas que não foram tão submissas à mensagem e às propostas do "mestre". Nas moradias populares que ele construiu nos anos 20, em Lège e Pessac perto de Bordeaux na França, os aspectos modernistas, considerados como "estranhos", "árabes", "estrangeiros", pelos habitantes proprietários, foram modificados, transformados. Assim os terraços se cobriram de telhados, as janelas horizontais foram divididas em proporções verticais, os pilotis se fecharam, as fachadas receberam adornos, as plantas internas livres foram cortadas em quartos pequenos. Tudo isso para que elas parecessem mais "casas de verdade" (TUGNY, 2004).

\section{Referências}

BRASIL. Ministério da Saúde. Legislação em saúde mental: 1990-2004. $5^{\circ}$ ed. Brasília: Ministério da Saúde, 2004.

. Ministério da Saúde. Boletim Saúde Mental no SUS. Ano VI, nº

26. Brasília: Ministério da Saúde, 2007. 
. Ministério do Trabalho e Assistência Social. Manual de serviço para assistência psiquiátrica. Brasília (DF): Ministério do Trabalho e Assistência Social, 1973.

DORVIL, H. L 'habitation et la santé mental. In: Dorvil, H; Beauliu, A. (Orgs). L'habitation comme déterminant social de la santé mentale. Laval: Acfas, 2004.

FURTADO, J. P. Avaliação da situação atual dos Serviços Residenciais Terapêuticos no SUS, Ciência \& Saúde Coletiva, v. 11; n.3, p. 785-95, 2006.

FURTADO, J. P.; HOFFMANN, C.; MARDEN, F. Análise da lista de discussão da portaria 106/2000 do Ministério da Saúde. 2004; mimeo.

FURTADO, J. P.; PACHECO, R.A. Moradias extra-hospitalares para pacientes psiquiátricos em Campinas. Análise de uma experiência. Jornal Bras. Psiq., v. 47, n. 4, p. 179-84, 1998.

GUARIDO, E. L.; BRAGA-CAMPOS, F. C. Sentir-se em Casa no Olho da Rua: o desafio das moradias. Cadernos IPUB. 2006.

GUIMARÃES, J.; SAEKI, T. Janelas do Santa Tereza: estudo do processo de reabilitação psicossocial do hospital psiquiátrico de Ribeirão Preto (SP). História, Ciências, Saúde, v. 8, n. 2, p. 357-74, jul./ago. 2001.

LEITE, L.; OLIVEIRA, M. Projeto equipe itinerante: equipe multidisciplinar da Pensão Nova Vida. Porto Alegre: Secretaria Municipal de Saúde, 2004.

LIMA, A. D. As regras legais e o processo de descentralização da Assistência Social no Brasil. Revista do Programa de Pós-Graduação e Política Social do Departamento de Serviço Social da Universidade de Brasília, v. 12, p. 87-114, 2003. 
MERCIER, C. L'Évolution des liens entre le logement et l'insertion sociale à travers 40 ans de documents ministériels au Québec. In: Dorvil, H.; Beauliu, A. (Orgs.). L habitation comme déterminant social de la santé mentale. Laval: Acfas, 2004.

MORIN, P.; ROBERT, D.; DORVIL, H. Le logement comme facteur $\mathrm{d}$ 'intégration sociale pour les personnes classées malades mentales et les personnes classées déficientes intelectuelles. Nouvelles pratiques sociales, v. 14, n. 2, p. 88-105, 2001.

ONOCKO-CAMPOS, R.; FURTADO, J. P. Entre a saúde coletiva e a saúde mental: um instrumental metodológico para avaliação da rede de Centros de Atenção Psicossocial (CAPS) do Sistema Único de Saúde. Cad. de Saúde Pública, v. 5, n. 22, p. 1053-62, 2006.

PALLADINI, P. C. Dois anos e meio de Lar Abrigado no Juqueri. Arquivos de Saúde Mental do Estado de São Paulo, v. 46, p. 62-67, 1987.

PIAT, M.; PERREAULT, L.A.; DORVIL, H. et. al. Les préférences résidentielles des pernsonnes atteintes de troubles mentaux graves: une étude descriptive. Santé Mentale au Québec, v. 32, n. 2, p. 89-97, 2008.

ROTELLI, F.; MAURI, D. Desinstitucionalização, uma outra via. A Reforma Psiquiátrica Italiana no Contexto da Europa Ocidental e dos "Países Avançados". In: NICÁCIO, F. (Org.). Desinstitucionalização. São Paulo: Hucitec, 2001. p. 17-59.

SUIYAMA, R. C. B.; ROLIM, M. A.; COLVERO, L. A. Serviços residenciais terapêuticos em saúde mental: uma proposta que busca resgatar a subjetividade dos sujeitos? Saúde soc, v. 16, n. 3, p. 102-10, 2007.

SYLVESTRE, J. et. al. Étude repère sur la stabilité résidentielle des personnes aux prises avec des troubles mentaux à Toronto: une approche participative em vue d'identifier les pratiques exemplaires em matière 
d'hébergement. In: Dorvil, H.; Beauliu, A. (Orgs.). L'habitation comme déterminant social de la santé mentale. Laval: Acfas, 2004.

TRAINOR, J. N. Housing for people with mental illnesses: a comparison of models and an examination of the growth of alternative housing in Canada. Canadian Journal of Psychiatry, v. 38, n. 7, p. 494-501, 1993.

TRAINOR, J. N. Le logement des personnes atteintes de troubles mentaux en Ontario: analyse critique et perspectives d'avenir. In: Dorvil, H.; Beauliu, A. (Orgs.). L'habitation comme déterminant social de la santé mentale. Laval: Acfas, 2004.

TRUDEL, J. F.; LESAGE, A. Le sort des patients souffrant de troubles mentaux très graves et persistants lorsqu'il $n^{\prime} y$ a pas d'hôpital psychiatrique: étude de cas. Santé Mentale au Québec, v. 30, n. 1, p. 47-72, 2005.

TUGNY, A. O imaginário da habitação e do habitar. 2004; mimeo. 



\section{A Utopia da Constituição do "Mapa" da Reforma Brasileira}

Simone Chandler Frichembruder

Nádia Geisa de Souza

\section{Introdução}

Em sua obra O Sonho do Cartógrafo, James Cowan (1999) traz as reflexões de Fra Mauro, cartógrafo veneziano do século XVI, cujo trabalho de sua vida era o de construir o mapa perfeito, um mapa que representasse a dimensão da criação. Nesta busca, inúmeros "curiosos", viajantes, exploradores visitavam-no em sua cela, trazendo a cada narrativa um mapa "mais completo". Contudo, acenavam para a impossibilidade de alcançar a perfeição de sua forma, tornando seu contorno cada vez mais extenso e incompreensível.

Movida talvez, pela utopia do cartógrafo na busca pelo "mapa perfeito", fui instigada a construir um "mapa da loucura", dos seus diferentes (des)encontros com a cidade. Semelhante ao cartógrafo veneziano, diante da "figura" que vai se constituindo da Reforma Psiquiátrica no território brasileiro, com contornos cada vez mais extensos e torneados por diferentes percursos em relação à loucura, sinto-me impelida a mapear os (des)caminhos para constitui- 
ção desta outra modalidade de atenção integral em Saúde Mental, denominada Serviços Residenciais Terapêuticos.

Para tanto, percorri as diferentes regiões do país, onde em cinco cidades "colhi" narrativas das experiências que vão configurando cenários da desinstitucionalização no Brasil. Assim, com a intenção de conhecer o cotidiano das relações e da vida dos moradores, nas suas residências, procurei conviver, mesmo que por um curto período, com os moradores, os cuidadores das casas e com os gestores. Tal relação permitiu-me criar "laços" de afeto e de confiança necessários para que pudéssemos conversar sobre as experiências que, ali, foram acontecendo. Dessas "viagens", trouxe, na "bagagem", as narrativas de alguns usuários dos Serviços Residenciais Terapêuticos cadastrados no Programa de Volta para Casa, de seus vizinhos e dos funcionários que os acompanham, como também de gestores dos projetos.

Neste artigo, (a)bordo alguns tracejos da coleta dessas narrativas na busca da "construção" desse mapa, cujo levantamento de dados encontra-se em fase final (FOUCAULT, 2000). A sua escrita está organizada em quatro momentos. Inicialmente, trago maneiras de agir com a "loucura" vivenciadas em diferentes culturas, visando a problematizar a sua pretensa universalidade e os jogos de exclusão que (des)configuram os tracejos do mapa Reforma no País. Em um segundo momento, realizo um traçado dos principais movimentos, Conferências e Dispositivos Legais que delinearam a constituição do Residencial Terapêutico no Brasil. Em um terceiro momento, apresento fragmentos, falas e cenas, de momentos vivenciados com moradores de Residenciais Terapêuticos para tencionar o morar em uma casa atrelada ao Sistema Único de Saúde. Para finalizar, narro momentos de minha passagem por um residencial do sudeste do país, buscando, ao dar "visibilidade" a outras formas de agir e escutar os moradores, chamar a atenção para a possibilidade de outros desenhos na construção do "mapa da Reforma" no Brasil. 


\section{A Nudez admitida na Região Norte e sua Intolerância no Sul do Brasil}

Para iniciarmos esta seção, uma reflexão de Michel Foucault sobre a "loucura" pode nos servir. Segundo ele, em "todas as sociedades há sujeitos que têm comportamentos diferentes dos dos outros escapando as regras comumente definidas" (FOUCAULT, 2002a) em pelo menos quatro domínios de atividades: nas suas relações com o trabalho; nos domínios da sexualidade, família e da reprodução da sociedade; nos domínios da fala e da linguagem e nos domínios dos jogos e das festas (FOUCAULT, 2002a), assumindo o lugar de marginais ao "infringirem" um dos domínios citados.

Tais colocações criam condições para pensarmos que estes "jogos" de exclusão diferenciam-se a partir das possibilidades de tolerância atribuídas a cada um dos domínios, descritos por Foucault, onde "cada cultura tem seu limiar particular" (FOUCAULT, 2000).

Para ampliarmos a discussão acerca da forma como as culturas lidam e configuram a "loucura", tomemos como exemplo a experiência de uma mulher que vive em um município da Região Norte. Luísa, cidadã conhecida naquela cidade, tem por hábito caminhar nua pela cidade. Os moradores, talvez, incomodados pela sua nudez, têm por costume procurar vesti-la. Mas ela, possivelmente, anda sem vestimentas não por falta de "condições financeiras" para adquirir roupas, pois mantém o hábito de andar pela cidade nua, com o rosto pintado, carregando uma bolsa, desprezando as vestimentas presenteadas.

Num dia, ao retornar para minha "morada de passagem" durante a coleta de dados, pude ver, em uma rua movimentada, uma mulher que andava pelas ruas de forma errante com os seios à mostra, vestindo apenas uma bermuda. Diante, daquela cena, o trânsito seguia na velocidade peculiar daquela capital. A mulher não provocava qualquer alteração, seja no movimento dos carros, ou nos 
sons emitidos, e não percebi os gritos peculiares dirigidos a mulheres com os seios à mostra, como talvez fosse acontecer na capital gaúcha. A polícia não participava daquela cena, parecia que ela era invisível aos demais passantes, levando-me a pensar que somente eu me perturbara com a imagem da errância nua daquela mulher na cidade. Na capital gaúcha, Luísa não poderia desfrutar de seu passeio sem roupas, sem receber a reprovação dos condutores de automóveis e a presença da polícia, que possivelmente interromperia a sua caminhada, direcionando-a para o hospício da cidade. A nudez, provavelmente, entraria no domínio da sexualidade, citado por Foucault, produzindo a exclusão de Luísa do espaço da cidade no Sul do país.

As cenas trazendo outros jeitos de lidar e conviver com o comportamento de Luísa, possibilitam-nos pensar que, naquela cidade, a "loucura", ainda, é admitida, reportando-me à familiaridade com a "loucura", na Idade Média, contada por Foucault (1995) ao nos falar sobre a história da loucura. Porém, diferentemente daquele período, hoje, encontram-se, ainda, institucionalizadas 41 pessoas no único hospital psiquiátrico daquele Estado.

Contudo, mesmo que existam diferentes significações em relação à loucura, o que não se distingue é o movimento de exclusão direcionado às pessoas que infringem qualquer um dos domínios mencionados de início, dando contornos ao mapa da exclusão construído durante séculos, através do reconhecimento da loucura em seu habitat. Tal modo de agir move-nos na direção de chamar a atenção para as maneiras como esses domínios vêm operando no processo de reversão do modelo hospitalocêntrico e de "inclusão" dessas pessoas nos espaços da cidade.

Diferentes movimentos precursores da Reforma Psiquiátrica, no cenário Mundial, dos movimentos sociais e Conferências de Saúde Mental realizadas no Brasil, impulsionaram uma gama de encaminhamentos em relação ao processo de "inclusão" e ao destino dos egressos dos hospitais psiquiátricos, com longo período 
de internação, até a instituição da portaria No 106/2000 que criou os Serviços Residenciais Terapêuticos (SRTs) no território brasileiro.

Com o propósito de trazer elementos das condições históricas que tornaram possível "morar" em um Residencial Terapêutico, no Brasil, apresento, a seguir, alguns dos principais movimentos e deliberações das Conferências implicados na instituição dos SRTs.

\section{Movimentos de Desinstitucionalização da Loucura: a Constituição dos Serviços Residenciais Terapêuticos no Brasil (SRTs)}

Para pensarmos sobre a (des)institucionalização dos moradores de hospitais psiquiátricos, parece-nos útil retomar e ter como pano de fundo o conceito de cuidado de Saúde Mental. Segundo Alves e Guljor (2004), o cuidado baseia-se em duas premissas fundadoras: primeiro, a liberdade, segundo, a readequação ao convívio social. Para o autor, o cuidado passa "pela capacidade do sujeito operar suas próprias escolhas, seu potencial de estabelecer suas próprias normatizações pautadas em sua história e de forma singularizada" (ALVES; GULJOR, 2004). Salientam, também, a necessidade de contrapor o isolamento relegado à loucura, por meio de intervenções que catalisem a readequação dessas pessoas ao convívio social.

Os primeiros movimentos em oposição ao isolamento ocorreram, no Brasil, na década de setenta, fomentados por uma diversidade de questionamentos em relação à situação de descaso e de abandono dos moradores nos manicômios, nos quais viviam (vivem) em condições subumanas.

Em meio a um intenso debate interno nas instituições asilares, na década de oitenta, ocorreram iniciativas de humanização do hospital psiquiátrico. Conforme o Coordenador Nacional de Saúde 
Mental, Pedro Gabriel Delgado, por ocasião do I Encontro Nacional de Residenciais Terapêuticos, realizado em Paracambi-RJ no ano de 2004, consolidava-se, naquele momento histórico, “o período da reforma dos asilos, um período importante na história da reforma psiquiátrica do Brasil”. Segundo ele, apesar daquele período apresentar "poucas modificações visíveis a olho nu no sistema hospitalar", teve sua função como "escola fundamental para a formação de quadros e para o debate dos grandes impasses relacionados aos hospitais psiquiátricos”. Para ele, duas experiências marcaram o início da ideia da Residência Terapêutica. Uma, a experiência desenvolvida no Juqueri, no Hospital Franco da Rocha, que contou com a criação, nos anos 80, dos chamados "Lares Abrigados". Outra, a experiência de Barbacena com a construção de casas no espaço asilar, que, mesmo localizadas sob o "manto protetor da instituição", objetivavam a autonomia dos usuários e a melhoria da qualidade de vida dos mesmos. Porém, ele ressalta que, naquele momento, o desafio de humanização e democratização do asilo não dispunha de "uma construção teórica de como iríamos, de fato, conseguir atender a todas essas pessoas quando elas começassem a sair dos hospitais, quando nós começássemos a fazer com que elas saíssem dos hospitais".

O II Congresso Brasileiro de Saúde Mental, realizado na cidade de Bauru - SP, em 1987, constituiu-se em um marco para tais discussões, contando com a participação de diferentes segmentos sociais: entidades e categorias profissionais, familiares e usuários. Fundou-se, naquela ocasião, o denominado Movimento da Luta Antimanicomial, com o lema "Por uma Sociedade sem Manicômios", desenvolvendo uma crítica radical aos hospitais psiquiátricos.

No mesmo período, importantes movimentos no campo da Saúde Pública aconteciam no país. A $8^{a}$ Conferência Nacional de Saúde, realizada, em 1986, em Brasília, teve como fundamento a proposta da Reforma Sanitária. Posteriormente, foi aprovada a Lei Orgânica de Saúde $\mathrm{n}^{\circ}$. 8080/1990, construindo o Sistema Único de Saúde que tem como um de seus princípios, a universalidade do acesso, a equidade, a descentralização de recursos e a integralidade da assistência. 
A I Conferência Nacional de Saúde Mental, realizada em Brasília, em 1987, vem ao encontro dessa proposta, tendo como uma de suas principais premissas a reafirmação da Reforma Sanitária, tornado-se um marco na Reforma da Psiquiatria no Brasil. Em relação aos moradores institucionalizados, esta Conferência propõe a realização de um censo para a revisão da população de internos em hospitais psiquiátricos e a implementação de um programa de reabilitação "para esta população, partindo-se para a criação de espaços de habitação co-geridos e integrados aos espaços extra-hospitalares de atenção" (BRASIL, 1987).

Com aquele contexto político, na década de noventa, tiveram início as primeiras experiências que buscavam o "rompimento" com os muros dos hospitais psiquiátricos, através da criação de pensões protegidas e lares abrigados inseridos na comunidade.

Nesse processo de transição, a II Conferência Nacional de Saúde Mental, realizada em 1992, apontou modificações profundas no campo conceitual da Saúde Mental, reafirmando a integralidade e o trabalho intersetorial. Dessa forma, a Saúde Mental veio ao encontro da implantação do Sistema Único de Saúde, ao propor um conjunto de dispositivos sanitários e socioculturais que partem de uma visão integrada das várias dimensões do indivíduo, em diferentes e múltiplos âmbitos de intervenção (educativo, assistencial e de reabilitação). Salienta-se, assim, a necessidade das ações da Saúde Mental serem integradas a outras políticas, como de educação, cultura, esporte e lazer, seguridade social e habitação (BRASIL, 1992).

Em tal período, as pensões protegidas e os lares abrigados passaram a ser os locais para receber as pessoas oriundas dos hospitais psiquiátricos, aliando-se a ideia da criação de centros de convivências, como espaços de encontro com a cidade.

Segundo Juarez Furtado (2006), os municípios de Porto Alegre (RS), Campinas (SP), Santos (SP), Ribeirão Preto (SP) e Rio de 
Janeiro (RJ) foram pioneiros nessas experiências, gerando subsídios importantes para que tais iniciativas viessem a ser incorporadas como política do SUS, a partir da publicação da Portaria MS 106/2000, que criou os Serviços Residenciais Terapêuticos.

Esses movimentos desencadearam a aprovação, em 2001, da Lei Federal N 10.216 da Reforma Psiquiátrica, após 12 anos de tramitação até sua aprovação no Senado Federal. A Lei dispõe, em seus artigos, sobre a regulamentação dos direitos do portador de transtornos mentais, vetando a sua internação em instituições psiquiátricas com características asilares. Propõe para os pacientes egressos das instituições psiquiátricas uma

política específica de alta planejada e reabilitação psicossocial assistida, sob responsabilidade da autoridade sanitária competente e supervisão de instância a ser definida pelo Poder Executivo, assegurada a continuidade do tratamento, quando necessário (BRASIL, 2004).

A aprovação da Lei da Reforma Psiquiátrica foi fundamental na "legitimação" dos serviços substitutivos existentes no país. Estes serviços, por não contarem com esse dispositivo legal, encontravam-se, em alguns momentos, em situação desfavorável e frágil perante as diferentes instituições que contribuíram para a exclusão da loucura.

A III Conferência Nacional de Saúde Mental, realizada em dezembro de 2001, propôs a regulamentação imediata da Lei 10.216/01, com o objetivo de garantir a assistência ao portador de transtornos mentais em serviços abertos, prescindindo dessa forma da internação nos hospitais psiquiátricos e definindo as "unidades tipo CAPS como referência local, microrregional e regional local para assistência em Saúde Mental" (BRASIL, 2001). Nesta Conferência, deliberou-se, ainda, sobre o "destino" dos egressos do sistema asilar, que passaram a ter como referência, não mais os chamados Lares Abrigados e Pensões Protegidas, mas os denominados SRTs. 
A Portaria MS 106/2000, no Artigo $1^{\circ}$, dispõe sobre os SRTs

como moradias ou casas inseridas, preferencialmente, na comunidade, destinadas a cuidar dos portadores de transtornos mentais, egressos de internações psiquiátricas de longa permanência, que não possuam suporte social e laços familiares que viabilizem sua inserção social (BRASIL, 2004).

A criação dos Serviços Residenciais Terapêuticos, no entanto, gerou uma imensa gama de questionamentos no que se refere à forma tanto dos cuidados nesses espaços como dos usuários suprirem suas necessidades diárias de alimentação, vestuário, lazer...

Em 2003, foi votada a Lei 10708 denominada De Volta para Casa, que cria o auxílio Reabilitação Psicossocial para as pessoas que ingressam nos SRTs ou retornam para suas famílias. Esse auxílio ampliou o poder contratual dos usuários, através da viabilização de abertura de conta bancária e da aquisição de cartão em seu nome para a retirada do benefício.

Alguns dos deslocamentos, operados nesse acesso e nas possibilidades de mudança no posicionamento atribuído ao portador de sofrimento psíquico, podem ser percebidos em falas como as de Líria. Esta, moradora de um Residencial Terapêutico da região Sul do país, ao referir-se ao Programa de Volta para Casa, coloca: "Eu não sou mental. Tenho cartão do banco!” (FRICHEMBRUDER, 2003). A moradora, ao situar-se como "não mental", contrapunha-se ao discurso da loucura enquanto doença mental e trazia o cartão de banco como uma marca significativa do seu "novo" lugar na cidade.

O gerente do banco, ao falar do Programa e de como foi se dando sua relação com os usuários na instituição bancária, trouxe um outro olhar ao dizer: 
Eventualmente um ou outro não veio com cartão, esqueceu o cartão, não lembra o número da conta. Mas este é o nosso dia-a-dia. Não são eles, não é uma exclusividade deles. Muitos clientes nos solicitam esta informação no nosso dia-a-dia, então não há diferença nenhuma. Eu sinto que eles se sentem cidadãos. A partir do momento que eles têm uma conta bancária, eles se sentem realmente pessoas atuantes, inclusas na sociedade (FRICHEMBRUDER, 2003).

Embora possamos problematizar a noção de cidadania vinculada a uma conta bancária e a finalidade de tornar o máximo de pessoas integradas e produtivas ao sistema econômico-político nas sociedades capitalistas, não podemos negar que, nos dias de hoje, na sociedade de consumo, as identidades e o sentimento de pertencer a determinados grupos sociais encontram-se marcados por ter ou não conta em banco e cartões de crédito.

O fato de ter uma conta bancária e ser dono de um cartão, de certo modo gerou novas configurações nas relações de tutela em funcionamento entre os cuidadores e usuários. Para ilustrar vejamos, como exemplo, a estratégia adotada pelos profissionais para o controle dos gastos dos usuários, através do recolhimento dos seus cartões, e como um usuário buscou garantir o recebimento e o uso de seu benefício. Paulo, inconformado com a retirada de seu cartão por sua cuidadora, que não aceitou o modo como ele usou seu benefício - gastou tudo no mesmo dia em que recebeu -, dirigiu-se ao gerente da sua conta. Apresentou-se como beneficiário do Programa e solicitou o recebimento do mesmo sem a documentação necessária para a realização de retiradas bancárias. O gerente, diante dos argumentos utilizados pelo "titular da conta", autorizou a transação bancária, atendendo a demanda do beneficiário.

Os exemplos citados trazem alguns elementos para pensarmos, o reconhecimento da "fala do louco" secularmente emudecida pelos muros do manicômio. A possibilidade de Paulo ser reconhecido em 
outro lugar, de forma semelhante à interpretação de Líria sobre si, ao intitular-se como "Não Mental" por ter um cartão bancário. Ao mesmo tempo, deparamo-nos com o controle dos profissionais ao retirarem do usuário o direito de utilizar o seu benefício, de cometer erros no orçamento, comuns na vida de outros habitantes da cidade, que driblam suas falhas na administração das finanças, através de contas com limite que cobrem e encobrem os seus gastos. Essas cenas, das vivências desses "novos" habitantes da cidade, trazem fragmentos de situações marcadas por "lutas" diante das possibilidades que vão sendo criadas para a vida dos usuários, conflitos gerados entre as ações dos cuidadores direcionadas ao controle das condutas dos usuários e os seus comportamentos de resistência, ao posicionarem-se seja como "não mental" seja como um "cliente bancário" de direitos.

Na próxima seção, apresento diferentes percursos e interstícios dos (Des)Encontros da Loucura com a Cidade, na criação de possíveis "desenhos" do mapa da Reforma Brasileira. Para tanto, trago narrativas tecidas no convívio das pessoas (cuidadores, usuários e vizinhos) nos Residenciais e na cidade, buscando mostrar outras tramas construtoras de (im)possibilidades de vida, já que "as linhas do enredo diferente das quais as pessoas participam as constroem de modo diverso" (LOPES, 2001).

\section{"Esta casa, não é a minha casa"! Os Residenciais e sua inserção Sistema Único de Saúde: Labirintos que se Entrecruzam}

Samuel, morador de um Residencial Terapêutico, na região Centro-Oeste do país, durante uma de nossas conversas junto com os demais moradores de sua residência, comenta: "Esta casa, não é a minha casa!". A escuta dessa fala, naquela manhã, causou-me perplexidade e tristeza. Esses sentimentos - gerados, talvez, pela 
minha trajetória e militância na Saúde Mental e pelo afeto que passei a sentir no convívio com aqueles moradores - "impediram-me" de retornar para o Residencial, no período da tarde, conforme havia programado. A sensação de impotência diante de seu descontentamento, levou-me a pensar: O que levaria Samuel a não sentir aquela casa como sua?

Esta pergunta reportou-me às contribuições de Benedetto Sarraceno (1999) que nos aponta para a necessidade de estabelecermos um diferencial entre "estar" e "habitar" e de olharmos para as relações de poder que se estabelecem no morar. Segundo o autor, "o estar tem a ver com uma escassa ou nula propriedade (não só material) do espaço por parte do indivíduo, com uma anomia ou anonimato do espaço em relação à organização material e simbólica", enquanto o habitar "tem a ver com um grau sempre mais evoluído de propriedade (não só material) do espaço no qual se vive”. Todavia, ele ressalta que, mesmo nas nossas casas, podemos ter uma perda do poder contratual, material e simbólico, experimentando um aprisionamento no habitar (CAMARGO JÚNIOR, 2004).

Ao chamar a atenção para o aprisionamento do habitar, mesmo nas nossas casas, Sarraceno leva-nos a pensar sobre a complexidade do "habitar um serviço", vivendo sob o "olhar" e as diretrizes do Sistema Único de Saúde. Para pensarmos na abrangência dessa questão e nos possíveis interstícios do morar em um Residencial, talvez sejam úteis as contribuições de Juarez Furtado (FURTADO, 2006). Ao analisar a portaria que institui os Serviços Residenciais Terapêuticos, Furtado refere que esta é "freqüentemente questionada por diversas razões [...] Sobretudo a palavra 'serviço' acaba levando erroneamente, a idéia de alguma similaridade com centros de saúde, clínica”, etc. (FURTADO, 2006), mas assim estabelecida para justificar sua inserção no Sistema Único de Saúde (SUS).

A inserção dessas moradias no SUS, como forma de garantia do financiamento para a Saúde Mental, insere em um Ministério (no 
caso o da Saúde) dois direitos do cidadão, Saúde e Habitação, através de uma única política pública.

Outro aspecto das diretrizes do Sistema Único de Saúde a ser repensado refere-se à definição de integralidade nos cuidados. A esse respeito Kenneth Rochel de Camargo Júnior (2004) alerta para o expansionismo semântico a que a integralidade está sujeita. $\mathrm{O}$ autor questiona "se é possível, ou mesmo desejável", um tipo de atenção que se dirija à "totalidade das necessidades de um ser humano", apontando como contrapartida desta expansão "o risco de um grau de controle sem precedentes, de perda de autonomia, uma medicalização também integral”.

Os comentários de Samuel, morador em um Residencial, em uma de nossas conversas com seus amigos sobre o cotidiano de suas vidas, trazem elementos que nos fazem interrogar sobre os riscos do expansionismo da atenção. Ao falar sobre o livro para "passagem de turno" utilizado pelos cuidadores do Residencial, ele diz: "Antes quem regia as nossas vidas era o hospital psiquiátrico, agora quem rege as nossas vidas é a Secretaria de Saúde!”.

Ao nos reportarmos às considerações de Camargo Júnior (2004) sobre a "indefinição de integralidade" e aos comentários de Samuel sobre o morar naquele Residencial, vemos como vital, nesse processo, estarmos atentos ao que o autor chama de "imperialismo sanitário". Pois, possivelmente, o sentimento de "não pertencimento" de Samuel ao Residencial onde vive e a afirmação de que sua vida é "regida pela Secretaria de Saúde" estejam permeados por este "açambarcamento de toda experiência humana sobre a rubrica da saúde” (CAMARGO JÚNIOR, 2004).

Foucault (1986), ao discutir os movimentos precursores da Reforma Psiquiátrica, refere que "as relações de poder constituíam o a priori da prática psiquiátrica”. Em suas análises sobre a História da Loucura e a constituição da Psiquiatria, o filósofo nos propõe modos 
de olharmos para o funcionamento do poder nas instituições. Nesse sentido, salienta que

o essencial não é a instituição com sua regularidade, com suas regras, mas sim, precisamente, esses desequilíbrios de poder, [...]. [...] as disposições de poder, as redes, as correntes, as intermediações, os pontos de apoio que caracterizam uma forma de poder e que, creio, são precisamente constitutivos ao mesmo tempo do indivíduo e da coletividade (FOUCAULT, 2006).

A este poder, que atua no interior e através das instituições difundindo-se no campo social, Foucault (2006) denomina poder disciplinar. Uma forma de agir do poder, caracterizada por um conjunto de técnicas articuladas e direcionadas ao controle do tempo, da vida e do corpo do indivíduo.

A fala de Samuel sobre a regulação de sua vida pela Secretaria de Saúde, de certo modo, mostra o funcionamento dessa forma de poder disciplinar que o produz como sujeito, já não de uma instituição única (hospital psiquiátrico), senão de uma rede de instituições e saberes que fazem dele o "usuário" dos Residenciais terapêuticos. Parafraseando os termos da Reforma, um poder não hospitalocêntrico deve se constituir em uma imensa rede que pode ser "não substitutiva" a uma única instituição: o manicômio.

Assim, parece que precisamos olhar para a rede que produz o indivíduo e as coletividades, pois segundo Foucault, "aquilo com que se tem de lidar, antes de lidar com as instituições, são as relações de força nessas disposições táticas que perpassam as instituições" (FOUCAULT, 2006). Possivelmente, Samuel nos fala da articulação das funções institucionais com as formas táticas e estratégicas que se operam nas "teceduras" da rede hospitalocêntrica, estendendo-se e regulando a sua vida no Residencial Terapêutico na cidade. 
A respeito da relação terapêutica estabelecida nestes serviços, Maria Tavares Cavalcanti (2006), menciona que muito temos produzido em relação a chamada relação terapêutica, mas a coisa se complica quando começamos a pensar o que seria um Serviço Residencial Terapêutico: Casa ou Serviços. Se for uma casa, por que pensar em termos de uma "equipe responsável" por essa casa.

Ela destaca essa dicotomia de difícil saída a que estamos expostos, se pensarmos em uma casa tal qual conhecemos e vivemos. Ciente da impossibilidade de resolver tal impasse, Cavalcanti (2006) "propõe manter esta contradição casa/serviço viva, sem cair na contradição de resolvê-la", trabalhando nos "interstícios" desta contradição explorando ao máximo "suas diversas vertentes".

Esses (des)encontros, nesse percurso, associados a preocupação com a existência e complexidade deste morar/habitar, levaram-me a interrogar: Como seria esta casa, onde Samuel se sentisse como sendo a "sua casa"? Que morar contemplaria este habitar, dele ter um maior pertencimento a casa? Que casa seria esta para Samuel e seus amigos de Residencial?

Para ampliarmos tal discussão, lembremos que a portaria que institui os Residenciais dispõe, em seu Art. $1^{\circ}$, os Serviços Residenciais Terapêuticos como serviços destinados ao atendimento do portador de transtornos mentais. Essa função atribuída aos Residenciais, como "espaço para atendimento", me faz pensar nas possibilidades de Samuel constituir, ali, um local onde ele possa habitar no sentido proposto por Sarraceno, apropriando-se daquele espaço a ponto de percebê-lo como a sua casa.

Na busca, talvez, de um lugar para habitar e de atenuar esta "desapropriação" de seu morar, Samuel, em nosso primeiro encontro com a presença da orientadora deste projeto, dirige a ela a seguinte pergunta: "Poderias conseguir um quarto só para mim?" O morador, ao entrar na cozinha, lança esse pedido, causando-me constrangimento e impotência e, possivelmente, sensação semelhante nela, que 
respondeu: "Sou professora! Não tenho poder para isto". Sentados em torno da mesa da cozinha continuamos conversando com os moradores daquele Residencial. Contudo, a colocação de Samuel levou-me a perguntar: "Tem alguma coisa que poderia fazer vocês sentirem essa casa como sendo a sua casa?" Rosa, moradora, ali, responde: "Que cada um dormisse em um quarto e fosse dono da cama de seu quarto". À semelhança de Samuel, ela clama por um espaço seu, solicitando além do quarto, uma cama que seja a "sua cama".

Outra questão apontada pelos usuários, referente ao modo de vida nos residenciais, relacionou-se ao número de moradores nos Residenciais. Kátia, moradora de um Residencial da região sudeste, ao falar da sua experiência na primeira casa onde morou, depois de sair do hospital e das dificuldades encontradas, fez o seguinte comentário: "Seis mulheres numa casa, não têm jeito, não!".

Essas colocações trazidas pelos usuários nos remetem a pelo menos duas discussões. Uma, relacionada ao número de pessoas contempladas na Portaria dos Serviços Residências Terapêuticos, que, em seu artigo $6^{\circ}$, ao definir as características físico-funcionais dos SRTs, delibera que essas sejam compatíveis para abrigar no máximo 8 (oito) usuários. Nas regiões percorridas, observamos a tendência dos gestores de organizarem grupos de oito pessoas como forma de garantir um maior número de usuários vivendo na cidade e a consequente racionalização dos recursos do projeto. Nesta tentativa de "racionalização", encontramos a criação de moradias com quartos para três ou quatro pessoas ou, até mesmo, a prática de separação de quartos para os armários e quartos só para as camas, dificultando a possibilidade de constituir espaços individualizados.

Outro importante aspecto da vida dos moradores mencionado por eles refere-se às ações de reabilitação psicossocial, que permeiam a constituição dos Residenciais, conforme aponta Terezinha, moradora do Residencial onde vive Samuel. Na conversa sobre o morar ali, fez o seguinte comentário diante das colocações de seus amigos: "A gente não paga aluguel que está nos direitos de cada um, né! Fica 
toda a vida!”. Assim, vemos aparecer a noção de um projeto para toda vida, no qual a moradora se posiciona como "moradora eterna" do Residencial.

A fala de Samuel, sobre a "substituição" do gerenciamento de sua vida do hospital psiquiátrico para o "reger" da Secretaria de Saúde, aponta para o funcionamento, nesse modelo de atenção - "ação" pensada para a melhoria das condições de vida dos usuários e humanização do cotidiano das pessoas - de elementos sociais similares àqueles das propostas dos lares abrigadas e das pensões protegidas.

Oliveira e Conciani (2008), ao analisar a experiência de implantação dos Residenciais onde vivem Samuel, Terezinha e Rosa, destacam que:

As demandas de gestão mobilizaram de modo mais premente e todo o processo se restringiu a "construção" administrativa das residências, como locação de casas, contratação de cuidadores, garantia de alimentação, entre outros. Com uma equipe reduzida e precarizada nas condições de trabalho (grande parte contratada temporariamente) e nas relações de poder político, o processo de aprendizado técnico-político de construção desse novo dispositivo de cuidado foi praticamente ausente. (OLIVEIRA, CONCIANI, 2008).

Em relação às colocações da autora, trago um excerto de meu diário de campo, onde narro fragmentos da conversa e meus sentimentos e percepções após quatro dias de trabalho e encontros, naquele Residencial, com Samuel, Carlos, Terezinha e Rosa:

Passei cerca de quatro dias nessa casa. Fiquei mexida e triste. Eram pessoas muito jovens e lúcidas; lúcidas dessa maquiagem da Reforma... Samuel diz em nosso bate-papo: 
"Agora quem rege nossas vidas é a Secretaria de Saúde!" Carlos comenta: "Antes os documentos estavam no hospital psiquiátrico. Perderam! Agora fizeram os novos e eles estão na Secretaria." Samuel, coloca de forma clara: "Esta casa, não é a minha casa!" Passei por uma situação de constrangimento, pois todos se apresentavam como sendo aposentados e os gestores falaram-me que os moradores não precisavam de mais dinheiro, por isso não pediram o LOAS para ninguém! Então, como eram aposentados? Falei então do De Volta para Casa. Terezinha ficou feliz e perguntou-me: "O que? Tu vais nos levar para a casa?" Foi horrível, pois se encheu de esperança "apostando" que estava ali para levá-la para casa! Tentei explicar o que era o De Volta para Casa. Eles não sabiam do que se tratava. Continuaram dizendo que estavam aposentados, sem serem aposentados legalmente. Fiquei mal. Não consegui voltar à tarde para o Residencial (FRICHEMBRUDER, 2003).

Nessas conversas, tornou-se visível a falta de perspectiva na vida daquelas pessoas, de ter um sonho, ou simplesmente, uma cama sua, um quarto. Ao mesmo tempo, percebi, com certa lucidez, os meandros da Reforma Psiquiátrica em curso, quanto o gerenciamento do tempo daquelas vidas e corpos através das ações da Secretaria de Saúde, delineando fragmentos do "Mapa da Reforma", borrados de figuras e formas similares à vida no hospital psiquiátrico. Vidas de pessoas que se encontram e convivem num "sobradinho verde, muito bonito", conforme anoto em meu diário de campo.

"Sobradinho verde, muito bonito", mas com histórias de pessoas que, diferentes de Líria que se posicionou como "não mental" ao ter um cartão bancário do benefício De Volta para Casa, foram "aposentadas" pelos gestores ao receberem o mesmo programa, cujo 
auxílio visa a reabilitação psicossocial e não o posicionamento dessas pessoas como inaptas para o trabalho.

No curso das visitas aos Residenciais, ao compartilhar de momentos de refeições, vi-me na presença de utensílios que, de certo modo, falam dos lugares e dos olhares instituídos para essas pessoas. Como descrevo num fragmento do diário de campo: "Nessa casa vi as tais canecas azuis que tinham no hospital onde trabalhei no Sul, e também onde pesquisei no Nordeste, agora estavam ali nos Residências do Centro-Oeste”.

Num outro dia, ao conversar com Fabiana, uma amiga e cuidadora dos SRTs do Sul, comentei sobre o uso das canecas de plástico nas regiões onde eu havia estado. Diante de minha observação, ela comenta parecendo estar intimidada: "Engraçado! Volta e meia, aparecem canecas azuis na casa onde sou acompanhante. Não sei de onde elas vêm, mas trato de botar elas fora!" A sua cumplicidade e desconforto diante das canecas azuis de plástico me confortavam. Contudo, intrigava-me a dimensão da irritação gerada pela presença desses utensílios nos SRTs. Mas, por que trazer as canecas azuis para o diário de campo, para as conversas com os amigos e para a discussão de um artigo?

Nas discussões que faz sobre a posição do narrador, Jeanne Marie Gagnebin (2004)1 assinala que o narrador é uma espécie de "sucateiro", isto é, aquele que traz os restos, esse personagem encarregado de pegar aquilo que parece sem significado e fora da história oficial, mas que carrega consigo marcas, memórias e experiências. Assim, no percurso de narradora e de desenhar o mapa de (Des) Encontros da Loucura com a Cidade, penso e vejo nessas canecas/ sucatas uma permanência silenciada, cuja forte presença, até hoje, carrega marcas dos modos como se pensou e agiu com relação à "loucura" no Brasil.

1 Segundo as análises de Walter Benjamin (1994), no seu texto intitulado O narrador, considerações sobre a obra de Nikolai Leskov. 
Ao encontrar, novamente, tais sucatas, em outras regiões percorridas pelo país, pensava que deveria tê-las fotografado como "prova" de minha visão. Mas o que queria provar? O uso das canecas azuis, em substituição aos copos de vidro, possivelmente, fala de um cuidado com o corte, de um possível corte a ser evitado com o uso de canecas inquebráveis; de um "possível lance" de "possíveis agressores" no convívio na casa instituída para prestar atendimento ao portador de transtornos mentais, conforme referenda a Portaria.

Essa presença, nas casas, conta de um olhar invisível e vigilante que vigia "sem estar presente, já que a vigilância poderá ser mais que virtual" (FOUCAULT, 2006). Um olhar sutil do poder disciplinar que controla e ordena os acontecimentos nos espaços, da casa onde habitam ou na hora de saciar a sede, quando ao lembrar: Cuidado, você pode se tornar perigoso! Segundo Foucault (2002b) o conceito de periculosidade da loucura dá-se pelo intercruzamento do diálogo entre o direito penal e a necessidade de respaldo da medicina higienista para afirmação da Psiquiatria enquanto ciência médica.

No entanto, Foucault chama nossa atenção para o fato de que essa noção não está centrada somente na Medicina ou no Direito, mas "são todas as disciplinazinhas da escola, da caserna, do reformatório, da usina, que tomam cada vez mais espaço. Todas essas instituições proliferando, estendendo-se, ramificando suas redes em toda a sociedade" (FOUCAULT, 1999). Ramificações que me parecem brotar, naquilo que vivenciei, como "ervas daninhas" nos espaços onde vivem os ex-moradores dos hospitais psiquiátricos.

Esses achados no mapeamento da desinstitucionalização no país fazem-me pensar em Fra Mauro. Este, ao compor o mapa perfeito do mundo, coloca que seu desenho, assumiu uma dimensão que não fazia parte de suas considerações iniciais, mesmo que ele pudesse presumir que estas poderiam ser, às vezes, contraditórias (COWAN, 1999). Na construção de um "mapa” da Reforma, inicialmente com traços que delineavam possibilidades de outros lugares, conquistados por Líria e Paulo na condição de clientes de um banco, 
fui percebendo modificações por lugares atribuídos à loucura, mostrando-me a "terra no céu, o céu na terra" (COWAN, 1999). Percebi um mapa da Reforma Psiquiátrica Brasileira de cabeça para baixo, com posicionamentos da "loucura" relacionados à "periculosidade" e à incapacidade. Aqueles que carregam as marcas da "loucura", ao infringirem as regras que orientam as relações em diferentes domínios sociais numa certa cultura, tornam-se excluídos, não mais (ou não só) em hospitais psiquiátricos, mas, agora, nos chamados Residenciais Terapêuticos.

Neste ponto do mapa, diante daquilo que vivenciava, uma questão me assombrava, "a dúvida recorrente sobre se estava conseguindo obter uma visão correta do mundo" (COWAN, 1999). Porém, o problema não é se essa visão que trago é correta ou não, visto que um olhar, ao ocorrer numa certa direção mostra um recorte, um olhar em perspectiva que, ao conhecer, desconhece tantos outros ângulos possíveis de ver e pensar o que chamei de (Des)Encontros da Loucura com a Cidade. Assim, neste mapeamento, em certa medida panorâmico, trago, a seguir alguns fragmentos de minha experiência na região Sudeste do Brasil, onde emergiram elementos para pensarmos outras relações possíveis no cotidiano dos moradores e dos gestores dos Residenciais Terapêuticos.

\section{"Eu Vim para Casa e o Hospital Psiquiátrico ficou lá": A Casa das Xícaras de Porcelana}

"As águas de março" banhavam as extensas margens dos rios, em minha passagem por uma cidade do interior no Sudeste do país, no final do verão. O inverno dava seus primeiros sinais de futura chegada e as vestimentas trazidas de minha viagem pelo Norte do país não davam conta do vento frio que batia nos meus pés. Comprar sapatos para "portador" de pés grandes, nessa cidade, era inviável, pois as pessoas na média tinham estatura mais baixa ou pés menores. Eu "fugia” da norma, naquele lugar "de sapatos e pés 
pequenos”. O jeito era caminhar mais rápido para atenuar o frio, dar uma parada para tomar um café quente ou pegar um táxi, tentando burlar o vento frio que chegava de mansinho.

Numa dessas tentativas de fugir do desconforto, aceno para um taxista desta "estranha" cidade sem semáforos nas ruas. Um senhor moreno e estatura baixa abre a porta de seu veículo, recebendo-me de forma amistosa. Peço, então, para que me leve para a Rua da Cartomante. Francisco, o taxista, roda pela cidade, em busca dessa estranha rua que eu apresentava para ele, no trabalho de campo que realizava em sua cidade.

Num certo momento, virando à direita, chegamos a tal da "Rua da Cartomante". Ao confrontar o número do Residencial com a localização que eu recebera, aviso ao taxista que estávamos em frente à casa que buscava. Francisco, então, com certa incomodação me pergunta: "Por que a senhora não me disse que iria num SRT? Se a senhora pedisse pelo SRT, eu lhe traria direto".

A pergunta de Francisco era inesperada naquele "ponto" do mapa? O lugar do Residencial na cidade, para "além dos muros do manicômio" alinhavava os borrões do "Mapa da Reforma" de uma outra forma.

As moradoras daquela casa, Marilda e sua amiga Kátia eram clientes de Francisco. Sem perceber, eu já havia entrado em "seu Residencial” antes mesmo de encontrá-las. Francisco já as apresentava como "boas negociantes", contando-me que existe uma combinação entre eles, delas pagarem somente a ida do percurso em um chamado, se a volta para casa se der em um pequeno espaço de tempo.

Ao descer do táxi, gritos, vindo da casa, interrompiam meu impulso de chegar até o portão. Eles contrastavam com os "gritos dos loucos", moradores das instituições psiquiátricas. Eram "gritos de caturritas", que, além de sinalizarem a minha aproximação daquela morada, anunciavam a presença de vida naquela casa. 
Ao entrar, depois de receber as boas-vindas de Kátia e Marilda, uma imagem causou-me impacto no encontro com elas. As paredes rosa-claro da sala, cobertas até o teto por pratos e xícaras de porcelana, que, também, cobriam o rack do aparelho de som, a mesa de aproximação e o balcão da sala. As louças de porcelana eram destacadas por duas exuberantes samambaias da Amazônia e outras lindas plantas, que ora disputavam o "papel principal" ora compunham um cenário de indefinível beleza.

O encantamento pelos ornamentos de vidro e pela composição, naquele momento, acalentou o meu desconforto na presença das canecas de plásticos em diferentes pontos do país. A fragilidade desses utensílios mostrava-me um cenário diferente da Reforma, visto que com um simples toque tais objetos poderiam se desintegrar, machucar o seu portador ou outra pessoa. Numa perspectiva de exclusão, representariam um risco num local para atendimento, mas, neste Residencial, estavam como ornamentos e objetos colecionados por Marilda.

À semelhança de Fabiana (cuidadora e amiga com quem conversara sobre as canecas azuis), possivelmente Marilda, afinada com aqueles gestores do Projeto, não "admitia" canecas de plástico como anúncio da "periculosidade dos loucos”, e em seu lugar, xícaras de porcelana "revestiam" os móveis e as paredes da casa, impedindo brotar, ali, aquelas "ervas daninhas".

Essa cena me traz à lembrança a conversa que tive com a gerente administrativa de uma das "casas com canecas de plástico". Ao perguntar-lhe por que não constavam, em suas listas de compras, copos de vidro e facas, fui surpreendida com uma outra pergunta: "Como vou dar facas e copos para quem viveu em hospitais psiquiátricos?”

Marilda, colecionadora das xícaras porcelana, ao receber meus elogios sobre a beleza de seus objetos, de sua composição com as samambaias exuberantes, respondeu-me orgulhosa: "Eu vim para casa e o hospital psiquiátrico ficou lá!”. 
Ao passar pela sala de estar, fui encaminhada à sala de jantar. Nela, as moradoras mostraram-me seus objetos e móveis, que foram substituindo aqueles adquiridos pela Secretaria de Saúde e pela ONG, parceira na administração do Projeto daquela cidade.

No percurso de minha visita pela casa de Kátia e Marilda, vou sendo encaminhada à área de serviço. Acima de uma das portas, encontro as anunciantes da minha chegada, as caturritas: Kika e Coca! Ao direcionar a máquina fotográfica para elas, Kika põe-se a frente da gaiola e arrepia suas penas, exibindo-se com sua plumagem.

De volta para os aposentos da casa, Marilda abre um dos quartos que estava com a porta fechada. Ao abrir, dá triste notícia que Sueli, a dona daquele quarto e sua amiga, falecera. Conta-me que, após sua morte, elas transformaram o quarto em uma sala de televisão, colocando um sofá vermelho com almofadas onde Nina, a gata da casa, passou a dormir. As amigas falam da falta de Sueli, da torta que compraram para ela um dia antes dela falecer, pois Sueli "adorava doces”. Contam-me, também, um dos pedidos que ela fez antes de morrer, que Marilda "não brigue” mais com Kátia.

Em função da morte de Sueli, os gestores apontaram a possibilidade de outra pessoa vir morar com elas, e ambas pediram para continuar morando "sozinhas" naquela casa. A esse pedido, receberam a contraproposta de passarem a pagar suas despesas de alimentação, até então pagas pela prefeitura e pela ONG, e foram chamadas para discutir a situação apresentada com ambos os gestores.

A condição posta pelos gestores provocou certa revolta em Kátia e Marilda, por acharem que deveriam continuar "recebendo tudo", utilizando seus benefícios apenas para a compra de roupas e o lazer. Enquanto Marilda, mesmo inconformada com as novas exigências, expressa com palavras a importância deste momento em que passam a financiar a sua alimentação, Kátia demonstrou inconformidade total com a proposta. 
Esta casa, com seus objetos, móveis, contas para pagar, bichos de estimação, amigos na cidade, parece criar condições para o habitar de suas moradoras, em contraste ao "morar" abordado anteriormente.

Esses encontros naquela cidade, com o taxista, a vizinhança da Rua da Cartomante, lugar ocupado por Marilda, ao "colocar as cartas" para suas amigas do bairro, apontam possibilidades de dar existência para outros olhares e lugares no "entorno" e no espaço do Residencial.

Num outro momento, em uma entrevista com Lúcia, uma das gestoras do Projeto desde o início de sua implantação naquela cidade, sobre aquela casa, ela me contou que esse habitar foi se configurando num processo de "diluição" da experiência inicial de criação do primeiro Residencial. Segundo Lúcia, aquela experiência ocorria dentro de uma lógica hospitalar, com a presença de um médico e uma psicóloga no interior da casa. Ela conta que foi muito trabalhosa esta primeira casa, as pessoas não sabiam como fazer. Ao falar sobre essa primeira experiência, que "resultou" na constituição da casa onde vivem, hoje, Marilda e Kátia, Lúcia conta:

A casa hoje tá completamente diluída nas outras, até mesmo porque isso tinha relação de poder, que de modo é complicado [...], entendeu? Ela (referindo-se a Marilda) exercia um poder de dona da casa, [...] e que tem que tá atento a isso, [...]. Ninguém agüentaria ficar o resto da vida com ela, porque ela não é fácil né? Agora ela deu uma acalmada, ela chegou, acho que ela queria, a companheira que ela queria para morar é essa, o perfil é o da Kátia (FRICHEMBRUDER, 2003).

Retornando à conversa com as moradoras sobre o morar num Residencial, Marilda contou-me que uma dificuldade, no início, foi a presença de Ana: "que ficava jogando o remédio fora e ela 
ficava chorando o tempo todo". Kátia lembrou de uma outra moradora, que deixava o banheiro sem condições de uso, com fezes no entorno do vaso sanitário, o que tornava impossível receber visitas. Ela menciona, também, problemas gerados pelo número de pessoas morando numa mesma casa. Essas dificuldades levaram Marilda e Kátia a solicitar morarem juntas em uma casa diferente da de Rita. Esta, segundo seu desejo, passaria a morar sozinha. Diante disso, os gestores concordaram em alugar um outro imóvel para as amigas e uma casa para Rita morar sozinha. Possivelmente, essa primeira experiência de Marilda, Kátia, Sueli e Rita as moveria na direção de dizer, assim como Samuel, "Esta Casa, não é a minha casa!"

Dentre as peculiaridades dessas experiências nos Residenciais, onde vivem Samuel e Marilda, pode-se dizer que se diferenciam as relações com os gestores dos Projetos. No primeiro caso, do morador Samuel, os gestores construíram uma visão exitosa, não problemática daquela experiência. No segundo caso, os gestores olham a experiência numa perspectiva problematizadora que tenciona as situações vividas e usa os "erros" e as dificuldades para mobilizar o pensamento na direção de novas possibilidades no enfrentamento dos conflitos. Esse modo de lidar com os acontecimentos cotidianos torna-se visível na fala de Lúcia:

Então assim, tem erros, acho que tem erros, acertos e a gente vai, do modo como aparece um problema, tenta achar uma solução pra ele, tenta fazer com que isso seja novo pra todo o funcionamento, mas às vezes demora pra acontecer! Você às vezes dá conta: ó nós estamos errando ali, pode melhorar isso aqui, sabe?

Com essa atitude inventiva de "soluções" engendradas nos problemas cotidianos, tais gestores poderiam ser descritos por suas posturas de atenção e de escuta às demandas dos usuários, 
que desacomodam e colocam à prova as "verdades" e as "certezas" adquiridas no saber especializado sobre o modo de agir num serviço, mesmo residencial, ligado ao campo da Saúde. Em lugar do saber dos especialistas, pareceu-me que, ali, vão se configurando saberes e ações ligadas às existências individuais e coletivas, que vão diluindo projetos iniciais, como a "primeira casa", e abrindo possibilidades para moradias que "colocam em suspenso" o morar, num Serviço de Saúde, referendado na portaria ministerial.

Assim, esses tracejos do mapa da Reforma em diferentes pontos do país, mais do que apontar para a necessidade de revisão da Portaria Ministerial, que delibera sobre os SRTs, de modo que se criem condições para ações interministeriais, por exemplo através de políticas habitacionais, e para a diluição de intervenções fundadas, ainda, num possível "imperialismo sanitário", mostram a urgência de se atentar e rever a forma como os ex-moradores de hospitais psiquiátricos estão sendo vistos ao ingressarem e viverem nos Residenciais.

Para além de um dispositivo legal, a existência nos Residenciais, cabe-nos uma atitude atenta ao olhar e ao posicionamento atribuído à "loucura", em espaços criados não apenas para "substituir" o manicômio, mas sim para desenvolver uma outra forma de nos relacionarmos com estes outros diferentes, que chamamos de loucos. Lugares, onde se poderia dar passagem a outros modos de viver, diferindo, por exemplo, do "cultivo (in)discriminado" das canecas de plástico, como forma de "proteção" de seus habitantes e "cuidadores". Modos de viver, que não esboçassem, nas "entrelinhas”, a periculosidade e a incapacidade dessas pessoas gerirem suas vidas, agora, nos Residenciais.

Finalmente, o que nos incita a esse pensar sobre a loucura? Com a intenção de deixar espaço para outros tracejos, para além dos realizados aqui, nesse mapeamento inicial dos modos como nos relacionamos com as pessoas que vivem, hoje, nos Residenciais, 
trazemos as palavras de Foucault, que nos convidam a um encontro diferente com isso que chamamos de doença mental:

Saberemos apenas que nós outros, ocidentais idosos de cinco séculos, fomos sobre a superfície da terra essas pessoas que, dentre outros traços fundamentais, tiveram este, o mais estranho de todos: mantivemos com a doença mental uma relação profunda, patética, difícil talvez de formular para nós mesmos, mas impenetrável a qualquer outra, e na qual experimentamos o mais vivo de nossos perigos, e, talvez, nossa verdade mais próxima (FOUCAULT, 2002a).

\section{Referências}

ALVES, D. S.; GULJOR, A. P. O Cuidado em Saúde Mental. In: PINHEIRO, R.; MATTOS, R. A. Cuidado: as fronteiras da integralidade. Rio de Janeiro: Hucitec, 2004.

BRASIL. Ministério da Saúde. Secretaria de Atenção em Saúde. Legislação em saúde mental: 1990-2004. 4º ed. Brasília: Ministério da Saúde, 2004.

. Ministério da Saúde. Departamento de Ações Programáticas Estratégicas. Relatório Final da $3^{\circ}$ Conferência Nacional de Saúde Mental. Brasília: Ministério da Saúde, 2001. Disponível em: <http://portal. saude.gov.br/portal/arquivos/pdf/relatorio_da_3_conferencia_de_saude_ mental.pdf $>$. Acesso em 15/06/2009.

Ministério da Saúde. Departamento de Ações

Programáticas Estratégicas. Relatório Final da $2^{\mathrm{a}}$. Conferência Nacional de Saúde Mental. Brasília: Ministério da Saúde, 1992. Disponível em: <http://portal.saude.gov.br/portal/arquivos/pdf/ 
relatorio_da_2_conferencia_de_saude_mental.pdf $>$. Acesso em $15 / 06 / 2009$.

. Ministério da Saúde. Departamento de Ações Programáticas Estratégicas. Relatório Final da $\mathbf{1}^{\mathbf{a}}$. Conferência Nacional de Saúde Mental. Brasília: Ministério da Saúde, 1987. Disponível em: <http://portal. saude.gov.br/portal/arquivos/pdf/relatorio_da_1_conferencia_de_saude_ mental.pdf. $>$. Acesso em 15/06/2009.

CAMARGO JÚNIOR, K. R. Um Ensaio sobre a (In)Definição da Integralidade. In: PINHEIRO, R.; MATTOS, R. A. Construção da Integralidade. Rio de Janeiro: Hucitec, 2004.

CAVALCANTI, M. T.; VILETTE, L. S. Casa e/ou Serviços Residenciais Terapêuticos no Contexto da Reforma Psiquiátrica Brasileira. In: FIGUEIREDO, A. C; ALBUQUERQUE, P. (Orgs.). Desinstitucionalização. A Experiência dos Serviços Residenciais Terapêuticos. Rio de Janeiro: Instituto de Psiquiatria UFRJ, 2006. p. 83-91. [Cadernos IPUB, n. 22]

COWAN J. O Sonho do Cartógrafo: meditações de Fra Mauro na corte de Veneza do século XVI. Rio de Janeiro: Rocco, 1999.

FOUCAULT, M. O poder Psiquiátrico. São Paulo: Martins Fontes, 2006.

A Loucura e a Sociedade. In: FOUCAULT, M. Ditos e Escritos I Problematização do sujeito: psicologia, psiquiatria e psicanálise. Rio de Janeiro: Forense Universitária, 2002a. p. 259-67.

. Os anormais: curso no Collège de France (1974-1975). São Paulo: Martins Fontes, 2002b.

Doença Mental e Psicologia. Rio de Janeiro: Edições Tempo Brasileiro, 2000. 
FOUCAULT, M. Problematização do sujeito: psicologia, psiquiatria e psicanálise. Rio de Janeiro: Forense Universitária, 1999.

A História da Loucura. São Paulo: Editora Universitária; 1995.

. Microfísica do Poder. Rio de Janeiro: Edição Graal, 1986.

FRICHEMBRUDER, S. C. Os (Des) Encontros da Loucura com a Cidade A Caminho de Casa: do Hospital Psiquiátrico São Pedro a um conjunto Habitacional na Zona Norte de Porto Alegre. Porto Alegre: FACED/ UFRGS, 2003.

FURTADO, J. Avaliação da Situação Atual dos Serviços Residenciais Terapêuticos no SUS: In: FIGUEIREDO, A. C.; ALBUQUERQUE, P. (Orgs.). Desinstitucionalização. A Experiência dos Serviços Residenciais Terapêuticos. Rio de Janeiro: Instituto de Psiquiatria UFRJ, 2006. p. 39-52. [Cadernos IPUB, n. 22.]

GAGNEBIN, J. M. História e Narração em Walter Benjamin. São Paulo: Perspectiva, 2004.

LOPES, L. P. M. Práticas narrativas como espaço de construção das identidades sociais: uma abordagem socioconstrucionista. In: RIBEIRO, B. T.; LIMA, C. C.; DANTAS, M. T. L. (Orgs.). Narrativa, Identidade e Clínica. Rio de Janeiro: Instituto de Psiquiatria UFRJ, 2001. p. 55-72. [Edições IPUB-CUCA]

OLIVEIRA, A. G. B.; CONCIANI, M. E. Serviços residenciais terapêuticos: novos desafios para a organização das práticas de saúde mental em Cuiabá-MT. Rev. Eletr. Enf. [Internet]. 2008; 10(1): 167-78. [Acesso em: 2009 jun. 15]. Disponível em: http://www.fen.ufg.br/revista/v10/n1/ v10n1a15.htm.

SARRACENO, B. Libertando Identidades: da reabilitação psicossocial à cidadania possível. Belo Horizonte: Te Corá Editora; 1999. 


\section{“E agora, o que vai ser da gente?" - Fim de um hospital psiquiátrico: relato de caso em Campina Grande-PB}

Ana Angélica Pereira Souza

Maria do Carmo Eulálio

Em abril de 2005, a cidade de Campina Grande-PB assistiu ao fato que talvez tenha representado a mudança mais radical na saúde mental deste município: o descredenciamento pelo Sistema Único de Saúde (SUS) do maior hospital psiquiátrico da cidade. Isto é, o Ministério da Saúde rompeu o convênio com a instituição, o qual era responsável pela manutenção da grande maioria dos pacientes ali internados. O hospital atendia ao município de Campina Grande e municípios circunvizinhos, os internos - como ocorre em geral eram de baixa renda, alguns já haviam se tornado moradores daquele lugar, em alguns casos já estavam no hospital há mais de 40 anos e haviam perdido o vínculo familiar.

O descredenciamento foi motivado tanto por irregularidades da instituição como pela tendência nacional preconizada pela Reforma Psiquiátrica, que prevê a redução dos leitos psiquiátricos e a substituição do modelo assistencial centrado no hospital (hospitalocêntrico) por serviços comunitários, nos quais o usuário não fique internado nem abandone o meio social em que vive. A Reforma Psiquiátrica, 
tão difundida na atualidade, é produto de um processo longo que traz consigo toda a problemática da loucura, como era entendida e encarada através dos tempos.

\section{Evolução da loucura ao longo da história}

Por muito tempo, a loucura foi objeto de fascínio do homem. Foi na Idade Média que tal posicionamento mudou, atribuiu-se à loucura um lugar na hierarquia dos vícios. Por volta do século XVII, a loucura tornou-se domínio da razão e foi silenciada pelo poderio da Ciência, culminando no aparecimento do "Hospital dos loucos", e do grande internamento (FOUCAULT, 2004).

$\mathrm{O}$ isolamento dos doentes mentais do mundo exterior em instituições psiquiátricas teve como principal defensor Philippe Pinel, médico francês do século XVIII. Foi Pinel quem utilizou pela primeira vez o conceito de alienação mental, dando a ideia de alguém que se encontrava afastado da realidade. O referido médico justificava o isolamento tanto pelo aspecto epistemológico (isolar para conhecer) como pelo valor terapêutico (isolar para tratar) (AMARANTE, 2003). Segundo Pinel, seria absolutamente necessário "confiar os alienados a mãos estrangeiras e [de] isolá-los de seus parentes", constatado pela experiência repetida (AMARANTE, 2003).

Como na época da Revolução Francesa a ideia de asilo contradizia o lema "Liberdade, Igualdade e Fraternidade", atribuiu-se ao asilo o espaço para a cura da Razão e consequentemente da Liberdade. Assim, como o alienado não era considerado cidadão, por não possuir a liberdade de escolha e sim desrazão, o asilo cumpria o papel de tornar o alienado um sujeito de direito (AMARANTE, 1995).

Goffman, sociólogo canadense do século XX, analisou as "instituições totais", isto é, lugares onde o indivíduo é isolado da sociedade, tendo todas as suas atividades concentradas e normalizadas. Para o 
autor, o internado chega à instituição com uma "cultura aparente", que é derivada de um "mundo da família". Esta seria uma forma de vida, um conjunto de experiências que permitiam um modo de defesa para enfrentar conflitos, dúvidas e fracassos, e a instituição cumpria um papel de "desculturamento", que tornava o interno temporariamente incapaz de enfrentar aspectos de sua vida diária (GOFFMAN, 2003).

Assim como a crítica de Goffman, surgiram outras quanto ao tratamento dispensado aos doentes mentais (Foucault, Rosen, Castel, Szazs, Burton). Desenvolveram-se por muitos países, diversas correntes que defendiam mudanças na psiquiatria da época, as 'Reformas Psiquiátricas'. Um dos fatos que impulsionaram o aumento das críticas ao modelo assistencial vigente foi a Segunda Guerra Mundial. Quando ela teve fim, muitos críticos passaram a comparar o estado dos manicômios a campos de concentração, causando repulsa na população aquele modelo e abrindo espaço para que novas propostas fossem experimentadas.

Algumas das mais significativas foram: a Psicoterapia Institucional na França (anos 1950), que defendia o tratamento do doente pela instituição e da instituição como um doente - referindo que a instituição também não se encontrava "sadia"; a Psiquiatria Comunitária ou Preventiva (década de 1960) nos Estados Unidos: Gerald Caplan, seu principal representante, apresenta a inovadora possibilidade de intervenção sobre as causas e a evolução das doenças mentais, isto é, prevenir o adoecer psíquico. Ele propunha que o tratamento fosse feito na Comunidade. O objeto da Psiquiatria, que até então era a doença mental, foi substituído pelo conceito de saúde mental, que é o que tem sido utilizado atualmente; a Antipsiquiatria (década de 1960) na Inglaterra, cunhada por David Cooper e que teve como defensores Laing, Szasz, Lidz e Arieti, e ainda Foucaut, Goffman, Deleuze e Guatari. Criticavam o papel da Psiquiatria na sociedade como instrumento de poder e prática punitiva, como por exemplo, o diagnóstico de muitos dissidentes 
políticos como esquizofrênicos na União Soviética. Questionava-se o tratamento psiquiátrico involuntário e o rótulo de esquizofrenia; na Itália desenvolveu-se a Psiquiatria Democrática Italiana, que teve como principal representante Franco Basaglia. Ele assumiu, em 1961, a direção de um hospital psiquiátrico da Itália e chegou com a proposta inicial de "transformar o manicômio em um local de cura" através da introdução de mudanças visando à humanização em seu interior. Essa proposta acabou se transformando numa atitude crítica frente às funções sociais, políticas e ideológicas da instituição psiquiátrica (AMARANTE, 2003).

A Reforma Psiquiátrica, no Brasil, tem como base as experiências da França e Estados Unidos, mas principalmente o modelo italiano.

Essa tendência discursiva foi sendo divulgada pelo Movimento dos Trabalhadores em Saúde Mental - MTSM. O movimento foi importante agente de transformação, com expressiva participação na definição das políticas públicas na área da saúde mental e ganhou força principalmente em meados da década de 1980. Ele introduziu uma nova abordagem crítica a respeito do gerenciamento da loucura, que passou a ter como objeto de modificação o próprio discurso científico. Um dos pontos principais dessa proposta é a desinstitucionalização.

A desinstitucionalização, conceito defendido pela reforma, consiste na substituição do hospital por um aparato de cuidados externos na forma de serviços substitutivos. Exige que de fato as práticas psiquiátricas passem a ser práticas de cuidado, realizadas na comunidade. Críticas pesadas são direcionadas a essa nova política quando se interpreta o termo desinstitucionalização como desospitalização simplesmente, ou desassistência ao doente mental e à família que o recebe de volta do hospital, sem condições necessárias para viabilizar o processo terapêutico (GONÇALVES; SENA, 2001).

Em 1989, surgiu o Projeto de Lei Paulo Delgado, que propõe a extinção progressiva do modelo psiquiátrico clássico, com sua substituição por outras modalidades assistenciais e tecnologias de 
cuidado. Esta lei só veio a ser aprovada em 2001, mas não institui mecanismos claros para a progressiva extinção dos manicômios. Essa lei, também chamada de lei da Reforma Psiquiátrica, preconiza a participação da sociedade e da família no tratamento e indica a internação apenas quando os recursos extra-hospitalares forem insuficientes.

Para Paulo Amarante (1995), o mundo do confinamento serviu não apenas à ordem econômica, mas também originou uma promissora "indústria da loucura", uma vez que a assistência psiquiátrica era em grande medida privatizada (terceirizada pelo Estado a hospitais particulares). Desde a época do surgimento do Projeto de Lei, os empresários dos hospitais psiquiátricos aterrorizavam os familiares, deturpando os princípios da Reforma, dizendo que os hospícios seriam fechados e os internos devolvidos aos familiares ou abandonados nas ruas.

Numa entrevista a Drauzio Varela, o médico e diretor do Instituto de Psiquiatria do Hospital das Clínicas da Universidade de São Paulo (USP) Valentim Gentil afirma que foi o surgimento de terapêuticas modernas (GOFFMAN, 2003) que possibilita a diminuição da necessidade de internação e não o fechamento dos leitos. Porém com a diminuição dos custos com internação, os governos passaram a usar os recursos economizados para outros fins que não a saúde mental. Segundo o médico, não se investiu em prevenção primária, nem se pensou nas famílias que não tivessem condições para receber o ex-interno psiquiátrico em casa para seguir as orientações dos profissionais de saúde (GENTIL, 2009).

Como podemos observar, as mudanças propostas pela Reforma Psiquiátrica atingem não somente o portador de transtorno mental, como toda a rede social que o cerca, a comunidade e a família. Neste estudo, interessa-nos especialmente a reação desta última ao fechamento do hospital onde se encontravam "em tratamento" seus familiares. 
A família a que nos referimos, é a família moderna típica. Ela tomou para si (ou lhe foram atribuídas) muitas funções. É a ela que cabe educar, cuidar da saúde, preparar para o mercado de trabalho, para viver em comunidade e para promover um desenvolvimento (emocional, escolar, sexual, esportivo, social) sem anormalidades para seus filhos. E esse tipo de família só surgiu na História Ocidental a partir do século XVII, na Europa. Até então, as famílias eram muito maiores e as casas eram abertas à visitação de amigos, clientes, clérigos e visitantes. Sem falar que a função de cuidar dos filhos era compartilhada com outras famílias (GENTIL, 2009).

Aliada a essas funções, a família também ganhou o status de portadora do "germe da irrupção da psicose, dos desvios do sexo e das mazelas do desenvolvimento infantil insatisfatório" (GENTIL, 2009, p. 49). E daí então passou a receber o apoio de estudiosos médicos, pedagogos, psiquiatras e psicanalistas, necessário para que dê conta de suas "funções".

Esse germe das mazelas é fruto da utilização, pela família, de táticas de poder, principalmente em relação à sexualidade: para impor as normas implícitas da cultura dominante - proibir, censurar e impor o rigor da lei (GENTIL, 2009).

O modelo assistencial mental que perdurou durante muito tempo foi o do isolamento familiar. Atualmente, porém, os familiares são percebidos como o elo de ligação mais próximo entre o portador de transtorno mental e o mundo. A participação deles no tratamento, tanto incentivando o familiar a se envolver no processo terapêutico, como na criação de associações, participação das reuniões e assembleias dos serviços, é tida como fundamental no sucesso do mesmo. Os familiares são preconizados como parceiros no tratamento (BRASIL, 2004).

Quando um membro da família vivencia um distúrbio mental, geralmente os outros familiares definem-se como sadios e apenas o parente submetido a tratamento que necessitaria de ajuda 
profissional. Entretanto, cada vez mais cresce a tendência a "cuidar do cuidador". Inclui-se, assim, no projeto terapêutico, o atendimento aos familiares, pois estes estão diretamente relacionados ao transtorno (BERENSTEIN, 1988).

Essa nova relação deve tentar ir além da atribuição à família do papel de "bode expiatório". Segundo Pereira (2003), as famílias, geralmente carregam uma história de "tratamentos" cheios de rótulos, reducionismos, linguagens técnicas longínquas, afirmações contraditórias e desencorajadoras a respeito da perturbação mental. Sendo esta complexa e incerta inclusive para a ciência médica.

A sobrecarga que recai sobre os familiares, muitas vezes, de baixa renda e que precisam prover as necessidades de um adulto improdutivo economicamente e ainda carente de cuidados especiais, além dos fatores de ordem emocional no convívio com a psicose, portanto hospital psiquiátrico representa ainda um "protetor" que mantém afastado do convívio familiar o "fantasma da loucura", pois a família, que raramente recebe atenção do sistema de saúde também sofre o peso do transtorno psíquico do doente. $\mathrm{E}$ que, portanto, deve-se evitar uma apologia anti-manicomial (PEREIRA, 2003).

\section{A desinstitucionalização e a Reforma Psiquiátrica em Campina Grande-PB}

Por meio do descredenciamento do hospital referido, uma parte da Reforma Psiquiátrica começou a se efetivar em Campina Grande-PB. Em menos de três meses, uma comissão responsável pela intervenção federal assumiu a direção do hospital, realizou mudanças emergenciais no funcionamento do mesmo e encaminhou todos os internos para tratamento em outros serviços. Diante de tantas mudanças repentinas, os familiares mostravam-se divididos e angustiados: concordavam com as denúncias da precariedade do tratamento oferecido pelo hospital, mas também se encontravam 
desesperados por não saberem o que iria acontecer com o seu parente, sob o medo dos rumores de que o hospital fecharia e as famílias que deveriam "tomar conta" de seus pacientes.

Para tornar mais fácil a transição, a equipe da intervenção realizou algumas reuniões com os familiares, nas quais os familiares podiam tirar dúvidas, esclarecer questões e ser informados das mudanças que estavam ocorrendo, além de expressar suas preocupações e dificuldades com a futura saída de seu parente do hospital.

\section{Realização da Pesquisa}

Com a autorização da equipe de intervenção, participamos das primeiras reuniões, totalizadas em número de quatro. $\mathrm{O}$ método utilizado foi observação de campo, também chamada de observação naturalista ou direta. Neste caso, eram registradas principalmente as falas dos participantes das reuniões, essas reuniões aconteciam no próprio hospital e eram coordenadas por uma médica psiquiatra, integrante da equipe de intervenção e, em geral, estavam presentes também outros profissionais. A reunião tinha início com a fala da psiquiatra, que informava sobre o que vinha ocorrendo no hospital e tinha a participação dos familiares, ora concordando com a psiquiatra, ora criticando a intervenção. Aproximadamente uma hora depois, a reunião era encerrada.

Verificou-se que as reuniões giravam em torno de dois polos distintos: as informações prestadas pela comissão da intervenção e as impressões dos familiares a respeito do contexto em que viviam. No primeiro polo, observamos os seguintes temas: as mudanças que vinham ocorrendo no hospital; o tratamento ideal para o transtorno mental; e esclarecimentos sobre os serviços substitutivos previstos pela Reforma Psiquiátrica. Já no polo dos familiares, observamos: as dificuldades concernentes ao transtorno; a defesa da existência do hospital; descrédito nas mudanças; e sinais de aprovação e esperança em relação às mudanças. 


\section{Informações prestadas pela comissão sobre a intervenção}

$\mathrm{Na}$ fala da comissão de intervenção, observavam-se elementos convincentes e coerentes acerca da Reforma Psiquiátrica, sobre como os portadores de transtorno mental devem ser tratados, que não devem ficar isolados do mundo, enfim, os objetivos daquela intervenção. A médica psiquiatra, representando a comissão de intervenção, fazia esclarecimentos sobre os transtornos mentais, que em sua grande maioria não têm cura, mas podem ser amenizados através do tratamento adequado, e que o dono do hospital não cuidava dos internos como devia, apesar de receber dinheiro suficiente para tal. Isto é, a comissão de intervenção tentava desconstruir a cultura da segregação e do isolamento do portador de transtorno mental que, como vimos, está entranhada na história da loucura desde tempos longínquos.

Podemos citar aqui alguns trechos da fala da comissão de intervenção, representada principalmente pela médica psiquiatra:

O Ministério da Saúde repassa cerca de novecentos reais por mês, por paciente ao hospital, o equivalente a mais de cento e vinte mil reais por mês no total, ele fiscaliza se esse dinheiro está sendo aplicado de forma responsável, que permita um mínimo de condições dignas aos internos, como alimentação balanceada, higiene, medicação e atendimento profissional. Mas desde o ano de 2002 o Ministério da Saúde vinha alertando que se o hospital não melhorasse suas instalações seria descredenciado. [...] o Ministério da Saúde encontrou o hospital em condições precárias, os pacientes sem comida, sem remédio, sem condições de higiene, sem luz, água e banheiros limpos nas alas. (Comissão da intervenção) 
A comissão também falava a respeito do transtorno, a concepção acerca dos limites e possibilidades de tratamento.

[...] ninguém nasce agressivo, a esquizofrenia não tem cura, o hospital não vai curar a esquizofrenia, o que se pode fazer é tentar correr atrás do prejuízo e tentar amenizar o sofrimento daquele familiar doente, que certamente é grande, é preciso aprender a conviver com as necessidades dele, deixá-lo no hospital não vai resolver o problema. (Comissão da intervenção)

E ainda falava dos diversos serviços substitutivos planejados para assumir o lugar do hospital e não desamparar internos e familiares.

Aqueles internos que já perderam o vínculo, assim como o espaço na família, ou não têm familiares serão encaminhados para residências terapêuticas 2. Inclusive já estão alugadas duas casas com este fim. Os demais internos da cidade de Campina Grande serão encaminhados para os CAPS existentes na cidade 3. Quanto àqueles de outras cidades, estão sendo feitas negociações com outros municípios, cogitando a implantação de serviços de assistência locais. (Comissão da intervenção)

2 "Entende-se como serviços residenciais terapêuticos, moradias ou casas inseridas, preferencialmente na comunidade, destinadas a cuidar dos portadores de transtornos mentais, egressos de internações psiquiátricas de longa permanência, que não possuam suporte social e laços familiares e que viabilizem sua inserção social” (Portaria No. 106/MS, de 11 de fevereiro de 2000, Art. $1^{\circ}, \S$ único)

3 Neste caso, o usuário mora em casa e vai ao Centro de Atendimento Psicossocial - CAPS, diariamente ou não, para ser atendido por equipe multidisciplinar. 
Para os casos em que a família se dispõe a receber o paciente de volta o governo criou o Programa de Volta para Casa - PVC, pelo qual a família recebe um auxílio de um salário mínimo para acolher o familiar de volta. (Comissão da intervenção)

\section{Impressões dos familiares}

Este polo abrange diversos temas frequentes, em menor ou maior intensidade, nas reuniões: experiências/dificuldades do convívio com o transtorno; defesa do hospital; expectativas/descrédito em relação às mudanças; percepções positivas acerca da Reforma Psiquiátrica.

Os familiares manifestavam uma grande necessidade de falar. Falar de suas experiências, citar situações críticas, dizer o quão é difícil, ou impossível, lidar com o parente com transtorno, os episódios de crise, a agressividade, as dificuldades no convívio, a necessidade de trabalhar e a falta de alguém que pudesse estar cuidando do portador de transtorno (e por isso a importância do hospital). Este fato sugere que nunca houve espaço, no tratamento dispensado, para que o familiar também fosse ouvido, fosse cuidado, ou denunciasse uma dor que nunca fora sanada. A dor e o sofrimento de quem convive com o transtorno mental de seu parente.

Quando meu filho for pra casa eu posso deixar ele num quarto com uma grade e com um cadeado?[...] Porque quando eu receber meu filho de volta vou construir um quarto, arrumar e deixar ele lá dentro, trancado. Vou chamar o juiz, mostrar e dizer que eu preciso fazer isso para poder trabalhar, porque 'solto' os vizinhos batem nele e ele acaba'se metendo em confu- 
são', se o juiz não gostar eu vou dizer pra ele pegar pra ele tomar conta. (familiares)

Meu esposo não tem condições de voltar para casa, pois lá tem criança e ele estupra quando vai lá. (familiares)

Meu filho é violento, para ele ser trazido foi necessário chamar a polícia e quatro pessoas para segurá-lo. (familiares)

A família sofre mais que o próprio paciente. (familiares)

Minha filha começa a fazer as coisas, lavar prato, depois de algum tempo começa a quebrar tudo. Já faz 18 anos que ela tá doente, fazia tudo pelo pai, começou a trabalhar aos 15 anos de idade e tanta responsabilidade a fez "enfraquecer o juizo", foi quando começou a ficar violenta e quebrar tudo dentro de casa; a irmã dela não vai de jeito nenhum no hospital, pois tem medo. (familiares)

Em alguns momentos, principalmente nos últimos encontros, alguns familiares mostram uma certa esperança e curiosidade sobre o novo serviço.

Eu fico feliz com essas mudanças porque eu vejo que minha filha será mais bem tratada. (familiares)

Quando eu vejo meu filho é só o que ele pergunta: quando vai para a casa nova [referindo-se às Residências Terapêuticas], pois "a doutora" tinha dito a ele que a casa é dele, assim como o que tem lá - televisão, geladeira, som... (familiares)

Como se faz pra entrar no CAPS? (familiares) 
Cada vez a gente gosta mais [referindo-se aos avanços da intervenção no hospital]. (familiares)

Os familiares percebiam a mudança no seu parente ao longo da intervenção: mudança na alimentação - a maioria dos internos engordou - o encaminhamento para a emissão de documentos daqueles que não tinham, para o médico, para especialistas, ginecologistas, dermatologistas, dentistas, tratamento de verminoses, piolhos etc.

Assim, os familiares mostravam-se com visões ambíguas da situação. Se por um lado, concordavam com o que era falado pela médica, por outro, não acreditavam na possibilidade de convivência com o parente com transtorno - devido às experiências de agressividade ao longo do convívio com o mesmo; ao mesmo tempo que, embora concordassem com as vantagens dos serviços substitutivos, não confiavam que ocorreria na prática como estava previsto no papel. Esta última preocupação devido às suas experiências com o serviço público de saúde mental.

Uma familiar falou do que achava da mudança e o que achava que iria acontecer:

Os interventores vão embora, aí no primeiro e no segundo mês vai dar tudo certo, mas depois vão deixar de pagar os funcionários, fechar as casas, pegar os pacientes e colocá-los num carro e levá-los para a colônia Juliano Moreira em João Pessoa. (familiares)

Deste modo, percebiam que o dono do hospital tinha cometido infrações, pois as condições dos pacientes não eram dignas. Viam inclusive que ele sequer seria punido pelo que fez.

O que eu entendo de tudo isso é que o dono roubou e que a gente é que vai pagar por isso, porque quem rouba uma galinha é preso, mas 
quem rouba muitos mil está na praia numa hora dessas, e enquanto isso, eu é que vou ter que me virar com dois que tem nesse hospital e mais dois que estão em outro. (familiares)

A descrença de que o novo serviço seria daquela forma anunciada pela comissão de intervenção tem por trás uma descrença maior - nos serviços públicos do país. E, portanto, o sentimento de desamparo experimentado pelo familiar ao longo do transtorno de seu parente. Daí talvez a valorização dada por eles ao hospital.

Alguns familiares demonstravam profundo agradecimento ao dono do hospital por ter sido este a solução para o seu problema, por ter aceitado seu familiar no momento de crise, no momento em que a família não sabia o que fazer. Uma relação que se revelava como uma dívida eterna dos familiares para com o dono do hospital, como se a internação fosse mais um favor do que um direito, uma relação assistencial e não profissional.

Mesmo ruim, foi aqui que deu apoio: três doido e só eu pra tomar conta e ainda tenho que trabalhar. (familiares)

O "dono do hospital" fez muito por mim, é que só quem vive é que sabe como é difícil lidar com essa situação. (familiares)

Foi o hospital que aceitou minha filha quando eu precisei. (familiares)

Eu agradeço em primeiro lugar a Deus e em segundo ao pessoal do hospital que o recebeu [familiar com transtorno]. (familiares)

Em uma pesquisa com familiares de portadores de transtorno mental frente à Reforma Psiquiátrica também se depararam com 
sentimentos de pessimismo e descrença nos ideais da Reforma (COLVERO; IDE; ROLIM, 2004), como se afirma:

Diante dos quadros graves de sofrimento mental e de longa duração, como a esquizofrenia por exemplo, encontramos familiares pessimistas quanto à possibilidade de melhora do familiar doente mental. Para muitos, são tantos os fracassos, recaídas, abandonos de tratamento, que é comum encontrarmos familiares desmotivados, resistentes e temerosos frente a qualquer proposta de mudança, vinda dos trabalhadores e dos serviços (AMARANTE, 2003).

Ante a dificuldade de lidar com o transtorno mental, os familiares defendiam o hospital como aquele lugar que os acolheu - mesmo com condições precárias - nos momentos de crise.

\section{Uma alternativa à insegurança}

Frente à dificuldade de os familiares acreditarem que eram possíveis as mudanças conforme idealizadas, a comissão sugeriu a criação de uma associação de moradores das residências, usuários, familiares e amigos, uma entidade independente, que defenda os direitos dos usuários. Sugeriu que esta associação participasse do Conselho Municipal e também da Conferência Municipal (GENTIL, 2009), e assim fiscalizasse o dinheiro que não vem simplesmente da prefeitura, mas do governo federal. Dessa forma, os familiares se sentiriam mais seguros quanto ao que viesse a ocorrer. Percebemos que os familiares começaram a desenvolver um vínculo de confiança com a médica psiquiatra. $\mathrm{O}$ temor, inicialmente relacionado à saída do interno do hospital, passou a se direcionar à possível saída dela e 
consequentemente ao medo de que tudo aquilo que foi discutido nas reuniões (por ela) não viesse a ocorrer.

- A senhora vai sair do hospital? (familiares)

- Em algum momento sim, eu sou assessora do Ministério da Saúde e estou cumprindo um contrato de quatro meses, que correspondem aos meses que vão de abril a agosto. A partir de agosto, mesmo não estando mais tão presente, estarei sempre em contato. Mas é muito importante que, na conferência municipal tenha um representante, por exemplo, da associação dos familiares, para que vocês saibam do que está acontecendo. (Comissão da intervenção)

\section{Considerações finais}

A realização deste trabalho permite uma reflexão ampla concernente à loucura. Percebemos o quanto é complexo falar de Reforma Psiquiátrica e de mudança dos serviços que se dispõem a tratar o transtorno mental. São questões políticas, de efetivação ou não da nova prática com qualidade (tão saliente nas indagações dos familiares), a dúvida "será que vai ser desse jeito mesmo que eles estão dizendo?", o medo de conviver com o transtorno que era velado enquanto o seu parente estava internado diuturnamente no hospital.

Por outro lado, há a difícil quebra de paradigma. A desconstrução do conceito de loucura historicamente construído - do portador de transtorno como perigoso, agressivo e irrecuperável. O abandono de técnicas desumanas, o fortalecimento da ideia referida numa das reuniões de que "sem carinho e sem afeto não vai!". E essa mudança fundamental - a mudança nas representações e crenças dos familiares - ocorre aliando segurança e credibilidade dos profissionais 
(em afirmar que este novo caminho é melhor que aquele) e melhorias concretas (como os familiares vivenciaram o cuidado efetivo aos internos do hospital).

Por fim, a principal desconfiança presente entre os familiares era quanto à permanência das mudanças positivas, o receio de que a prática não será como dizem na teoria. Neste ponto, a melhor solução seria a efetivação do Controle Social referido anteriormente, com a participação dos familiares na fiscalização e acompanhamento da política assistencial mental tão importante para sua vida e de seu parente. Esta, infelizmente, é uma cultura ainda incipiente no Brasil, que possui uma democracia recente.

\section{Referências}

AMARANTE, P. Saúde Mental, políticas e instituições: programa de educação à distância. Rio de Janeiro: FIOCRUZ, 2003.

Novos Sujeitos, Novos Direitos: o debate em torno da reforma psiquiátrica. Cad de Saúde Pública, v. 11, n. 3, p. 491-494, 1995.

BERENSTEIN, I. Família e doença mental. São Paulo: Escuta, 1988.

BRASIL. Ministério da Saúde. Saúde no SUS: os centros de atenção psicossocial. Brasília: Ministério da Saúde, 2004.

COLVERO, L. A.; IDE, C. A. C.; ROLIM, M. A. Família e doença mental: a difícil convivência com a diferença. Rev Esc Enferm USP, v. 38, n. 2, p. 197-205, 2004.

FOUCAULT, M. História da loucura na idade clássica. $8^{\circ}$ Ed. São Paulo: Edições Graal, 2004. 
114 | Residências Terapêuticas

GENTIL, V. Saúde mental. Entrevista a Dráuzio Varela, p. 29, 2009. Disponível em: <http://drauziovarella.ig.com.br/entrevistas/saudemental. asp $>$. Acessado em: 27/05/09.

GOFFMAN, E. Manicômios, prisões e conventos. $7^{\circ}$ ed. São Paulo: Perspectiva, 2003.

GONÇALVES, A. M.; SENA, R. R. A reforma psiquiátrica no Brasil: contextualização e reflexos sobre o cuidado com o doente mental na família. Rev.Latino-Am. Enferm, v. 9, n. 2, p. 48-55, 2001.

PEREIRA, M. A. O. Representações da doença mental pela família do paciente. Interface - comunicação, saúde, educação, v. 7, n. 12, p. 71-82, 2003. 


\section{Loucos? Histórias de vida, significados do sofrimento psíquico e (des)institucionalização}

Hudson Pires de Oliveira Santos Junior

Maria de Fátima de Araújo Silveira

Dulce Maria Rosa Gualda

Natalia Rejane Salim

\section{Iniciando o enredo da narrativa}

Diante da necessidade de aprofundar-nos no entendimento da relação cultura e processo saúde-doença, e aqui, particularmente, a doença mental, e dando continuidade às investigações conduzidas no âmbito das Residências Terapêuticas (SANTOS JUNIOR; SILVEIRA, 2009), surgiu a motivação de conduzir um estudo de cunho etnográfico com os egressos do hospital psiquiátrico, que foi descrito no capítulo anterior, deste livro.

Os internos que estavam saindo do hospital (ano de 2005), devido à intervenção do Ministério da Saúde, já eram considerados prováveis moradores dos Residenciais Terapêuticos a serem implantados na época, em Campina Grande. Porém, a articulação da equipe de intervenção com os familiares desses sujeitos atingiu sua proposta maior, que foi aceitação de alguns deles de volta ao seio familiar, garantindo um espaço de moradia e apoio. 
Entretanto, inquieta-nos a necessidade de responder a alguns questionamentos sobre o modo de inserção sociocultural desses sofredores psíquicos que passaram pelo processo de desinstitucionalização do Instituto Campinense de Neuropsiquiatria e Reabilitação Funcional (ICANERF), constituindo, então, o problema da presente proposta: Como está sendo a vida dos egressos do hospital psiquiátrico, após a desospitalização?

Para responder a tal questão, este estudo teve como objetivo: compreender qual o significado que os sofredores psíquicos atribuem a experiência de sair do hospital psiquiátrico, decorrente à intervenção do Ministério da Saúde, e como se dá o retorno destes atores sociais à comunidade. Buscou-se, dessa forma, apreender as categorias culturais relacionadas à problemática do adoecimento mental.

Para isso, o estudo ancora-se nos pressupostos da antropologia cultural e da etnografia como método de pesquisa qualitativa.

\section{Antropologia: fundamento para a caminhada}

Como afirma Minayo (1999), a doença é uma realidade construída e o doente um personagem social, o que indica a indiscutível importância da antropologia para a compreensão do processo saúde-doença, devido este ser composto por uma trama de fatos tanto clínicos quanto socioculturais, envolvendo, portanto, significação, interpretação e ações socialmente organizadas para promoverem a saúde e responderem à doença.

Considerando que a antropologiaéo estudo das culturas humanas em suas diversidades históricas e geográficas, Gualda e Bergamasco (2004) relatam que ela tem sido utilizada como uma perspectiva enriquecedora, na abordagem de temas relativos ao processo saúdedoença e dos universos sociais e culturais onde ocorrem. 
Destacam-se, então, dois enfoques teóricos na conceituação de cultura: o primeiro, comportamental, que se refere à observação do comportamento dos indivíduos de um determinado grupo social; e, o segundo, cognitivo, que busca conhecer e compreender as crenças, os valores e os conhecimentos desses sujeitos na abordagem do tema escolhido (GUALDA, 2002).

Nesse sentido e na tentativa de compreender o continuum saúde-doença mental em seus contextos socioculturais mais amplos, buscamos subsídios no referencial da antropologia cultural, pois sua utilização, quer envolva direta ou indiretamente o processo saúdedoença, pode constituir-se em uma perspectiva complementar e enriquecedora (GUALDA, 2002).

Contudo, as análises das Ciências Sociais, no campo da antropologia e sociologia, foram conduzidas por uma linha de relativização da doença mental. Pautando-se na revelação de que tanto a loucura quanto os modos de responder a ela emergem de determinados contextos sociais, ou seja, a loucura é um fenômeno sociocultural e possui as marcas da sociedade em que fora criada.

No século XVIII, entra no contexto o hospital psiquiátrico e a medicina, na figura do psiquiatra, que assume um papel de antiherói que, utilizando como pano de fundo o discurso terapêutico, exerce sua principal tarefa: a de controle social sobre a loucura.

O foco central é tirar das ruas as pessoas ditas loucas e levá-las para uma instituição manicomial, onde haja tratamento. Contudo, a eficácia desse sistema começa a ser questionada. As críticas apontavam para uma crise do sistema psiquiátrico, que além de não intervir na qualidade de saúde dos internos, era o produtor e mantenedor do adoecimento, responsável pelo alto índice de mortalidade e cronificação dessas pessoas, gerando inúmeras incapacidades sociais.

Em decorrência dessa realidade, cria-se um movimento internacional de Reforma Psiquiátrica, cujo objetivo é lutar pela desconstrução da assistência psiquiátrica hospitalar. O Brasil, em 
particular, orientou sua reforma psiquiátrica inspirando-se na experiência itálica de reversão dos hospitais psiquiátricos por dispositivos inseridos e articulados socialmente, com o intuito de alcançar a reinserção socioeconômico-cultural das pessoas em sofrimento mental e de re-estruturar as práticas de cuidados a elas despendidas.

Todavia, reduzir leitos e superar a condição cronificante de "moradores do hospital" a que muitos sofredores psíquicos são relegados implica a formação de alternativas de moradias para os futuros egressos, seja pelo suporte requerido para garantir sua permanência fora do hospital, seja pela dificuldade de reinserção familiar. Para isso, a atual política de saúde mental tem contado com o apoio integral dos Serviços Terapêuticos Substitutivos, em especial, as Residências Terapêuticas (RTs), instituídas pela Portaria 106/2000 do Ministério da Saúde.

\section{A etnografia deu significado às escolhas tomadas}

Dentre os métodos qualitativos existentes, este estudo adotou o etnográfico, a partir dos pressupostos da antropologia cultural interpretativa (GEERTZ, 1989). Segundo Gualda (2002), o elemento essencial da etnografia é buscar compreender o modo de vida da pessoa ou grupos na sua própria perspectiva. Ainda para a autora, a etnografia é um processo sistemático de observar, detalhar, descrever, documentar e analisar o estilo de vida da cultura de um determinado grupo de sujeitos.

O estudo foi realizado em Campina Grande, interior do estado da Paraíba, devido ao fato deste município está experimentando e implementando medidas para a desinstitucionalização de pessoas com internações psiquiátricas de longa permanência.

Com base na perspectiva teórica, decidimos trabalhar com as narrativas, pois é complementar para projetos que combinam 
histórias de vida e contextos sócio-históricos, sendo, portanto, adequadas para apreender os significados que os sofredores psíquicos atribuem a vivência com o transtorno mental.

\section{Para voltar no tempo é necessário um constante ir e vir}

Através da história de vida é possível emergir a linguagem própria de cada sujeito, que gera um discurso sócio-sentimental acerca do fenômeno que o envolve, que neste caso é o adoecimento mental. Em cada história de vida, existe um tom vital, que é a frase escolhida para servir de síntese da moral da narrativa. Eis os tons vitais:

Eu ia me casar e adoeci, foi por causa desse casamento, porque ele [noivo] me ligou dizendo que ia ter um filho... fiquei doidinha na hora, me disseram que era esquizofrenia simples. Eu ficava normal e não sei o que era que eu fazia. (Ana)

Quando eu era criança, desse tamanhinho assim, eu fui crescendo, crescendo, aí não colocaram roupa neu, aí eu fui ficando nervoso. Eu andava pelo mato, porque eu andava nu e tinha medo de gente, tipo índio. (Voni)

Meus irmãos começaram a me tratar como se eu fosse doida, perguntavam: "ta melhor?" Eu dizia: "melhor de que? Vocês são doidos e colocaram na cabeça que a doida sou eu. Não querem é que eu vá morar na casa de vocês e me apresentar como a mulher que não tem dinheiro". (Zoe)

Me disseram que eu tinha problema de cabeça... Quando eu ficava interno no hospital psiquiátrico, vixe Maria! Lá era ver uma cadeia, comida não prestava, era a mesma comida todo dia, eu lá passei muita fome. O tratamento era 
selvagem, que nem um bocado de burro tudo bravo, tinha remédio, tinha tudo, mas era doido com doido, era briga e mais briga. (José)

Ixe! Eu era a menina dos olhos de ouro de meu pai. Eu não podia ter uma febrezinha de nada que ele corria para um médico particular. Hoje bate uma decadência, tanto na estabilidade econômica como na estabilidade emocional. (Jucilene)

A partir das histórias de vida na íntegra, fizemos recortes que retratam as categorias culturais expressas:

\section{Naquela época era tudo diferente do que é visto hoje...}

Ao responderem a colocação do pesquisador "conte-me sobre sua história de vida", os colaboradores foram instigados à rememoração. Neste momento, eles se mostraram dispostos a relembrar de acontecimentos e de pessoas situadas nos diversos momentos de suas vidas. Como diz Santos (2000) voltar no tempo é um exercício que necessita de um constante ir e voltar, pois cada lembrança ancora-se em um momento do presente, pois “a lembrança é em larga medida uma reconstrução do passado com a ajuda de dados emprestados do presente".

Os colaboradores, quando constroem suas histórias de vida, fazem de forma bastante livre, sem se prenderem, na maior parte das vezes, a uma organização cronológica. Diante desse fato, a transcrição das entrevistas possibilitou uma leitura lógica e cronológica, quando possível, dos eventos narrados.

Eu sou natural de Souza-PB, eu vivia na fazenda quando ainda era criança, nessa época eu não fazia nada a não ser brincar com meu 
irmão 1. Aí, brincava muito, né? Corria, brincava nas mangueiras, nos açudes. (Zoe)

Eu sou de Santana do Cariri no Ceará, nasci no dia 11 de setembro de 1975, às 6 horas da manhã. Quando eu era criança, eu gostava de brincar um pouco de boneca, eu gostava muito de participar daquelas pessoas, daquelas meninas, daquelas crianças tudinho... naquela época, o regime era só brincadeira. (Jucilene)

Eu jogava bola, jogava pedra, fazia tudo, de criança, né? Jogava bola de vrido, bolinha de vrido, lascava cabeça de meninos que não era brincadeira, lascava com pedra... na brincadeira vale tudo. (José)

Pode-se observar que as narrativas trazem a origem do colaborador "sou de...", local onde foram vividos os "bons" momentos da infância, marcados por situações de brincadeiras, pois como traz a fala o "regime era só brincadeira", diferindo do contexto atual onde as crianças são encaminhadas para uma série de atividades diárias, como escola, natação, judô, informática e outras (seja a nível privado ou em Organizações Não Governamentais), cujo objetivo é tirar-lhes das ruas e oferecer uma suposta educação de qualidade, bem como proteger do perigo da violência urbana.

As narrativas trazem também as lembranças dos momentos na escola como um espaço de aprendizado, porém duas experiências nos chamam atenção, por se referirem aos colégios administrados por freiras.

Era bom no colégio que eu tive, Instituto Beneficente São José, no primário. Na década de 55 era muito diferente dessa década, eu gostava muito das quermesses que tinha no colégio, das freiras, eu estudei em colégio de freira. (Jucilene) 
Eu fui para as Damas (colégio administrado por freiras) pra estudar, né? Nas Damas eu era muito estudiosa, mas eu não tolerava lá, porque se você vai assistir aula só querem saber de filho de deputados e senadores, só dá cartaz a filhos de médicos, é essas coisas que eu nunca gostei. A mestra geral humilhava muito, pegava muito no pé com nossa roupa, nosso cabelo, sempre foi assim. Não tratava a gente muito bem, essas coisas machucam, né? Um erro só, puxava a campainha e todo mundo ficava de castigo, nessas horas tinha duas moças, filhas de um político famoso, com cara de sonsa, vivia agarrada na saia da freira, era essas diferenciações que eu já não aceitava. Aí, a gente cantava: "e o cordão do puxa saco cada vez aumenta mais", era uma turma perigosa a nossa! Naquela época era tudo muito diferente do que é visto hoje, né? (Zoe)

Novamente surge a referência em relação à diferença entre as épocas: "década de 55 era muito diferente dessa década", apontando mudanças no processo educativo, antes marcado por colégios religiosos, cujo rigor e a lei são o meio educativo. Tomando a análise das instituições totais no livro "Manicômios, prisões e conventos" (GOFFMAN, 2003), pode-se dizer que Zoe e Jucilene passaram, na infância, pela sua primeira experiência em uma instituição marcada pelas relações interpessoais verticais, mortificação da identidade pessoal e distanciamento dos espaços sociais.

É fato que a vida vai se passando e com ela vem o acúmulo de experiências:

Aí, quando eu me tornei adolescente eu gostava de praia, de brincar, de roupa nua, do jeito que as meninas passam aí na televisão. Eu era toda na moda, eu era danada, perigosa, 
namoradeira, namorava quando era nova. Meus pais não deixavam eu dar um prego numa barra de sabão, porque eles tinha condição regular, eles não deixavam. Quando eu era adolescente, gostava muito de passear no clube, no rio, nas festas boas, foi uma vida boa de mar de rosa. É tanto que hoje em dia não sei fazer nada, eu não sei lavar um copo que preste, se eu for lavar, minha filha vai e reclama, diz que eu faço mal feito, não faço bem feito. (Jucilene)

Em casa, eu varria a casa, eu arrumava, sabe? Adolescente começa com que idade? Eu trabalhava, passeava, gostava de passear, ali onde é hoje o camelódromo era o colegial, você não alcançou, viu? A gente ia passear à noite e ouvir música, todas as vezes ia, eu ia com minhas amigas, depois minhas amigas desapareceram, porque foram para outro lugar, aí eu saía com a minha irmã. Eu tenho 1 irmã e 1 irmão. Toda noite eu ia ao cinema, não pago, porque eu não podia pagar cinema toda noite, mas seu Zezinho do Capitólio (cinema) botava a mim e minha irmã para assistir o filme, depois das 8 horas, depois do jornal. Não me casei, cheguei bem pertinho de casar, só faltou mesmo ele vir. Ele vinha, mas eu pedi que suspendesse a viagem porque eu não podia deixar minha irmã e meu pai, não casei por isso e outras coisas também. (Ana)

Os relatos nos fazem visualizar como era o fluxo de amizades e o envolvimento nos espaços sociais: "gostava de passear". Outra dimensão que chama atenção são as questões amorosas: "namorava quando era nova" e "cheguei bem pertinho de casar". 
Para Heilborn (1991), a vida sexual, na rede social, permite que cada sujeito estabeleça uma relação consigo mesmo e com o mundo, garantindo uma dimensão de construção dinâmica, flexível e contextualizada no tempo e no espaço-histórico em que vive.

\section{"Disseram que eu tinha problema de cabeça..."}

Nesta categoria, não objetivamos fazer meras críticas ao hospital psiquiátrico, mas dialogar com as vivências dos colaboradores durante as internações, como meio para avaliar o dispositivo hospitalocêntrico, registrando suas características e, quando possível, estabelecer uma analogia com os princípios da Reforma Psiquiátrica.

Para Santos (2000), quando uma pessoa passa a relatar suas lembranças, transmite emoções e vivências que podem e devem ser partilhadas, transformando-as em experiência, para fugirem do esquecimento.

A partir desse momento, começam a surgir falas que apontam o surgimento do sofrimento psíquico.

... Eu andava nu e tinha medo de gente, tipo indio. O povo chamava: "lá vai o índio, lá vai o indio". Como eu andava nu, a minha mãe procurou o promotor e me trouxe para o hospital. Minha primeira vez não me levaram de novinho, não. Levaram com 15 anos, eu era assim: "desse tamanho, nu", vivendo no mato. Aí, juntou quatro policial, pegaram, algemaram eu e me levaram para o hospital. (Voni)

Eu adoeci foi por causa desse casamento, antes de marcar esse casamento eu tive raiva de uma bahiana, porque ela me escreveu dizendo que ia ter um filho dele. Aí, eu endoideci, fiquei doidinha na hora. Me disseram que era esquizofrenia simples. Eu ficava normal e não sei o 
que era que eu fazia. Tive de ficar internada por que eu tinha crises, dava a crise constantemente, e fui internada várias vezes, mais de 20 vezes, nos dois hospitais daqui [Campina Grande]. Eu nem sei dizer como eram as crises, quem sabia era papai e minha irmã, ela também era doente, a mesma doença dela é a minha. (Ana)

Eu andava demais, por tudo que era canto, eu batia Campina Grande todinha a pés, eu andava de mais! Eu morava com a finada minha mãe e ela dava conselho para eu parar em casa. Eu descobri sobre minha saúde depois de velho, com 30 anos, disseram que eu tinha problema na cabeça. Começou o seguinte: "uma crise que deu em mim, ai eu fiquei sofrendo da cabeça". Uma raiva que eu tive, mas eu não me lembro não. (José)

O adoecimento mental surge em várias facetas nas narrativas, pois culturalmente existem aspectos comportamentais que destoam como sendo da doença mental, cuja compreensão é o desvio das normas sociais, quebra dos padrões vigentes do comportamento sociável: "eu andava nu e tinha medo de gente"; "adoeci foi por causa desse casamento"; "eu andava demais". Andar sem roupa, isolar-se, andar sem destino são fatos que permeiam o imaginário social, relacionando as pessoas que apresentam tais comportamentos como "loucas", apontando o adoecimento mental como caso a ser isolado, por meio da polícia e da internação psiquiátrica. Para as mulheres sem companheiros, relaciona-se a "loucura" com a falta de sexo.

Além disso, tem-se a figura de estranhamento - "lá vai o índio" - fato que tem correlação com o termo alienado, ou seja, alguém que não faz parte do meio, como Amarante (2007) define: é alguém "de fora", estrangeiro, alienígena, fora da realidade, fora de si, sem o controle de suas próprias vontades e desejos. Fora do mundo, de outro mundo (no mundo da lua). 
Outro tema que surge é que eles não sabiam da "doença mental": "me disseram que era esquizofrenia"; "disseram que eu tinha problema na cabeça”. Interessante notar como os colaboradores não sabem do próprio adoecimento - o que faz nas crises? Quanto tempo dura? Quando fica bom?

Como a cultura é (era?) da internação psiquiátrica para as pessoas em sofrimento psíquico, as narrativas trazem as lembranças dos momentos vividos no hospital psiquiátrico, suas peculiaridades, condições assistenciais e estruturais.

No começo, eu entrei no soro, depois de quinze dias eu me senti tão mau com o remédio, haldol, era babando, tremendo assim, era tremendo igual uma vara verde, depois meu filho ia me visitar de 15 em 15 dias... Tomava as injeção, eu não dormia de jeito nenhum, passava mal lá dentro, era aquela ala, um corredor grande, agora eu vivia só trancada, quando meu fi chegava eu tava azeda, um grude, se não tivesse uma pessoa para banhar a gente, pra dar o que comer, ai: "vai, vai, vai para o chuveiro na marra"... Foi depressão, eu não tomei só esses remédios, não. Tomei diazepam, neuleptil, injeção de diempax, tomei sossega leão. (Jucilene)

Quando eu ficava internado no Hospital, vixe Maria! Lá era ver uma cadeia, comida não prestava, era a mesma comida todo dia, eu lá passei muita fome. O tratamento era selvagem, que nem um bucado de burro tudo bravo. (José)

As narrativas apontam a desassistência ao sujeito em sofrimento psíquico no modelo asilar, trazendo um pouco da realidade vivida no hospital psiquiátrico, apontando características como a medicalização excessiva: “me senti tão mau com o remédio", a característica 
de isolamento e distanciamento do mundo "lá era ver uma cadeia" e o tratamento desumano, com baixa qualidade "o tratamento era selvagem".

Todas essas particularidades são apresentadas por Goffman (2003), em sua análise sobre as instituições totais, marcadas pelo afastamento do interno de seu ambiente familiar e social, pelos maus-tratos e pela domesticação através de uso e abuso de medicações, para que os sujeitos se tornassem passivos frente ao processo de internação.

O caráter "total" das instituições, neste caso o hospital psiquiátrico, é simbolizado pela barreira à relação social com o mundo externo e por proibições à saída que, muitas vezes, (na maioria) estão incluídas no esquema físico - por exemplo, portas fechadas, paredes altas, arames farpados e outras:

...pulei o muro, o muro é alto, é quase da altura de um poste desse, eu procurava um jeito e subia, tinha segurança, ai quando eles via, puxava o cabra pela perna, me pegaram muitas vezes, ai botavam para dentro, eu era medicado, tomava injeção. Vixe Maria! Injeção duia pra caramba. (José)

Os internos eram obrigados a se adequar às regras do hospital, onde os menores segmentos de suas vidas estavam sobre julgamentos e regulamentos constantes por parte da equipe de profissionais, com o intuito de atestar a não autonomia daqueles.

No hospital, lá atrás era aonde a gente ia para as refeição. De manhã era a comida. "Ta na hora", todo mundo dizia: "ta na hora do café, ta na hora do almoço". A gente já sabia, nunca fui empurrada por aquelas meninas mais piores do que a gente, ficava sempre de lado, sabia me sair delas, no banho também. No banho era 
um sofrimento, viu? Ficavam o dia todinho, se era chuva, ficava o dia todinho na chuva; se era sol, ficava o dia todinho no sol. (Jucilene)

De manhazinha de 6 horas, essa hora ia tomar banho todo mundo, uma fila de banheiro, para comer era comida normal, feijão e arroz. Para dormir cada cá tinha uma cama, minha cunhada trazia cigarro, fósforo, só que não ficava comigo, ficava com a equipe, ai quando a eu queria dizia: "eu quero fumar", a equipe vinha, ai acendiam um cigarrinho". (José)

O aspecto central das instituições totais pode ser descrito como a ruptura das barreiras que comumente separam as três esferas da vida - o dormir, o brincar e o trabalhar, em diferentes lugares e com diferentes co-participantes - pois, em primeiro lugar, todos os aspectos da vida são realizados no mesmo local e sob uma única autoridade. Em outra dimensão, cada momento das atividades diárias do sujeito é realizado na companhia imediata de um grupo grande de outras pessoas, todas tratadas da mesma forma e obrigadas a fazer as mesmas coisas em conjunto - não há singularidade. Em terceiro lugar, todas as atividades cotidianas são rigorosamente estabelecidas em horários, toda sequência de atividades é imposta verticalmente, por um sistema de regras formais explícitas que devem ser cumpridas e que são garantidas por um grupo de funcionários (GOFFMAN, 2003), quando algum interno foge as regras, então sofre a punição:

Ai quando iam me dar uma injeção, eu sai correndo, mas me pegaram, deram a injeção e me colocaram lá, eu chorava, gritava tanto, lugar de doido, eu gritava: "me dá um copo de água pelo amor de Deus"! Eu fiquei 12 anos ali! Fui para passar uma semana e não sai mais... mas eu ficava fazendo planos para fugir, eu guardava dinheiro, eles tomavam, tirava, sei 
lá como que era aquilo, não tinha saída, toda noite eles me medicavam, ai sempre tinha a enfermeira. (Zoe)

A perspectiva de quem estava no manicômio era que não sairia mais, estava solitário, ser medicado para não fugir, não ter autonomia em relação a sua vida, não possuir dinheiro, pois este tem o simbolismo de poder, além da necessidade de pedir, importuno ou humildemente, algumas coisas pequenas - "eu quero fumar"; "me dá um copo de água" - fatos que causam, gradativamente, a mortificação do eu.

Contudo, essa realidade não continuou sem enfrentar questionamentos, pois em 1978 começaram a surgir as denúncias da violência dos manicômios, da capitalização da loucura, da preponderância da rede privada de assistência, bem como surgiu, coletivamente, uma crítica à psiquiatria clássica e ao modelo hospitalocêntrico no cuidado aos sofredores psíquicos, dando origem a Reforma Psiquiátrica e com ela o processo de desinstitucionalização dos internos dos hospitais psiquiátricos (SANTOS JÚNIOR, SILVEIRA, 2009).

Tal processo de desinstitucionalização foi vivenciado na pele pelos colaboradores do estudo, pois estavam internos na instituição manicomial quando esta sofreu intervenção do Ministério da Saúde e, como consequência, foi fechada devido às baixas condições para prestar assistência.

Ai o hospital fechou. Foi a queda do Hospital, foi a decadência. Ai, Pai J. [proprietário do hospital] disse assim: "olhe, vai fechar o hospital, eu não tenho condição de pagar a prefeitura, tá muito caro o custo de vida aqui, aí vão abrir um hospital que é uma... alugar um prédio"... Mas a minha vida foi lá no Hospital, tomando muito remédio, chamavam de coquetel, eram 6 a 8 drágeas por dia, era só remédio de manhã, 
de tarde e de noite. Eu acho que se ele ainda fosse aberto eu ainda ia estar lá, porque o doutor nunca ia dar alta a mim por completo, por que ele me queria eu lá dentro do hospital e só visitando a família. (Jucilene)

Mas lá [hospital psiquiátrico] não existe mais não, porque tava funcionando, mas fechou, não foi? E porque fechou? Quer dizer que não volta mais não aquele hospital? Volta não, porque não tem clima não! Disseram assim, quando chegou o derradeiro dia "a cantina vai se fechar, vocês vão sair, vai fechar o hospital". Quando fechou, o dono do hospital arribou [foi embora], não ficou não. Fechou porque no Hospital tava o povo dormindo no chão, outros fazendo coco no chão e coisando... tava maltratando, botando pra dormir em cama na talisca, quando chovia, ai o hospital no inverno era o maior frio do mundo, o frio da chuva, $e$ tinha uns que dormia no quartinho trancado, $o$ isolamento, dormia no chão. Quem dava o banho era os homens, minha irmã levou pra lá 8 bermuda e 10 camisa, quando foi pra lavar, eu que perdi. A doutora disse: "esse hospital aqui de todo jeito vai fechar". Chamou minha mãe de Princesa Isabel [município da Paraíba] dizendo que eu ia voltar para casa, ai eu disse: "eu não vou não". Ali ele perguntou: "você vai ficar aonde?". "Eu vou ficar até fechar, vou pra a unidade". Eu não tive alta de lá não, sai porque fechou. (Voni)

Vale pontuar que os colaboradores têm alguma noção dos motivos que levaram ao fechamento do hospital "fechou porque... tava maltratando", apesar de estar presente nas narrativas a colocação do proprietário do hospital, que se mostrou como injustiçado, 
afirmando que não recebia recursos para manter o funcionamento da instituição. Além disso, o que também é marcante é o fato dos colaboradores falarem com muita naturalidade que não receberam alta do hospital, que só saíram porque fechou, pois nunca iriam receber alta "nunca ia dar alta a mim por completo" - como está implícito na cultura, lugar de "doido" é no hospital.

Porém, após presenciar séculos de isolamento do "louco" e da loucura, o mundo consegue enxergar a ineficiência dos hospitais psiquiátricos, asilos e manicômios no tratamento da doença mental. É a partir desse despertar que se inicia a construção de novas formas de cuidar, com o objetivo de produzir saúde sem se ausentar do contexto social da cidade, ou seja, sendo substitutiva ao modo hegemônico e hospitalocêntrico.

\section{"Minha vida ta boa, boa assim... eu to sadio"}

De acordo com o Ministério da Saúde, após um diagnóstico aprofundado do hospital psiquiátrico do município, foi elaborada a proposta de desinstitucionalização, construída em conjunto com os atores envolvidos no processo de intervenção: a equipe interventora (indicada pelo Ministério da Saúde), os representantes da Secretaria Municipal de Saúde de Campina Grande e da Coordenação Estadual de Saúde Mental da Paraíba (BRASIL, 2007).

Dentre as medidas adotadas, foi elaborado um plano de altas, operadas criteriosamente, que exigiram articulações com famílias e serviços de saúde dos locais de origem dos internos. Em um período inferior a 02 meses, esse plano reduziu o número de "pacientes/leitos" (total de 176) do hospital, permanecendo, apenas, 38 sujeitos que já poderiam ser considerados "moradores", pois lá se encontravam entre 02 e 30 anos. Estes foram transferidos, logo em 
seguida, para o Centro de Referência em Saúde Mental, atualmente Unidade de Emergência Psiquiátrica.

Eu passei 7 meses na unidade [Unidade de Emergência Psiquiátrica], ficava dentro do quarto, merendava lá, tomava o lanche. Minha filha ia me visitar, meu filho ia também, até me tirar de lá, quando passou 7 meses. Mara, assistente social, muito boa, falou com meu filho. Ai foi o tempo que ele ajeitou um quarto para mim, ai foi quando eu fui me estabelecer. (Jucilene)

Chegou o dia de tirar a gente de lá [hospital psiquiátrico], arrumaram duas Kombi e encheram com a gente dentro, já tinha uma casa no Alto Branco [residência terapêutica] que foi morar a Gema e outras lá, eram as melhores, né? Depois, abriram outras casas perto do Hotel do Vale, eu fui olhar, os quartos eram grandes. Eu fui para o hospital de meu irmão 1, que tava alugado pela prefeitura para o pessoal que saiu do Hospital [Unidade de Emergência Psiquiátrica], lá eu jogava baralho, ia na missa rezar, passear na rua. Eu tava bem na época, de repente chega a notícia de sair, e me trouxeram para esse apartamento. (Voni)

Todos os colaboradores desta pesquisa se encontravam internos no hospital psiquiátrico por inúmeros anos, portanto os seus vínculos sociais e familiares estavam fragilizados ou, até mesmo, já haviam sido perdidos. Esse longo período de internação não é uma mera passagem na vida dos internos, pois os privam de seu bem maior que é a liberdade e a possibilidade de viver. 
Visando a uma melhor reintegração na comunidade, os egressos (moradores) do hospital foram encaminhados para a Unidade de Emergência Psiquiátrica - "eu passei 7 meses na unidade" - onde foram trabalhadas as questões iniciais do processo de ressocialização: "lá eu jogava baralho, ia na missa rezar, passear na rua", bem como foi um período de contato com os familiares para promover o retorno do ex-interno para o seio familiar: "minha filha ia me visitar"; ou outro espaço comunitário: "me trouxeram para esse apartamento".

Para os que não foi possível o contato com a família ou que a mesma não mais os aceitava, foram elaborados, paulatinamente, de forma planejada e avaliando-se caso a caso, encaminhamentos para as Residências Terapêuticas, espaço de morar e viver na comunidade. Nesse processo, em cerca de um ano, Campina Grande conseguiu reverter seu modo de atenção à saúde mental, passando do modelo hospitalocêntrico para o modelo de atenção psicossocial.

Eu sai de lá [hospital psiquiátrico] porque fechou, mas graças a Deus estou aqui [Residência Terapêutica], é melhor aqui, aqui é bom. Minha vida só não tem sido boa porque eu sinto umas agonias sabe, todos os dias eu tenho uma complicação, sabe? Todos os dias sabe a mesma coisa, não sei se depois do lanche até não sei que hora, mas não é culpa daqui não, é coisa lá de fora. Eu ouço vozes, eu tenho esse ouvido perdido e eu ouço vozes por aqui, por esse ouvido perdido, elas dizem o que esta acontecendo, esses escândalos que ta acontecendo por ai, eu sei que esta porque a televisão não dá, dá, mas confundindo, né?

É interessante o conteúdo que essa narrativa traz. Inicialmente, compara sua nova moradia com o tempo em que estava no hospital psiquiátrico: "é melhor aqui, aqui é bom"; em segundo lugar, traz 
uma desconstrução cultural sobre a loucura, a qual diz que escutar vozes - fato cientificamente chamado de alucinação auditiva - é sinal de crise. Contudo, a colaboradora relata a alucinação: "eu ouço vozes", como auxílio para entender os eventos que lhe rodeiam diariamente. Porém, não quero dizer que só porque essa colaboradora saiu do hospital e agora habita em uma residência, os sinais psicóticos são diferentes ou menos importantes, o que chamamos a atenção é para o fato de que antes, escutar vozes era um problema, geralmente determinante para a internação, e agora é o que a orienta sobre o mundo exterior.

Goffman (2003) diz que é característico dos internados que cheguem à instituição com uma cultura aparente - uma forma de vida e um conjunto de atividades aceitas sem discussão até o momento de admissão na instituição, porém se a estadia do interno é muito longa, pode ocorrer, caso ele volte para o mundo exterior, o "desculturamento" - que é a incapacidade temporária de enfrentar alguns aspectos de sua vida diária.

Hoje em dia não sei fazer nada, eu não sei lavar um copo que preste, se eu for lavar, minha filha vai e reclama, diz que eu faço mal feito, não faço bem feito. (Jucilene)

Eu não faço nada, nada, nada, só assisto televisão e me deito, não faço porque não consigo, mas tem ai, tem prato para lavar, eu não lavo nem meu prato... Eu vou na psicóloga, não sei a rua da psicóloga, é um consultório, eu só converso porque ela puxa conversa, mas eu não era assim não, fiquei depois [da internação psiquiátrica], eu gostava de conversar, mas agora não sei conversar com ninguém. (Ana)

Porém, esse fato não inviabilizou o resgate das questões de vida cotidiana mais elementar, que foram desconstruídas atrás 
dos muros manicomiais. Tal perspectiva estimula a autoestima, o atendimento das necessidades diárias, minimizando as limitações, potencializando os hábitos saudáveis e viabilizando a autonomia para a vida na comunidade. Pois, a realização das atividades do dia a dia deve ser tomada como um dos primeiros objetivos a serem alcançados nos projetos de reabilitação psicossocial (SOARES, SAEKI, 2006).

Elas pedem dinheiro a gente e eu compro alguma coisa, eu to comprando agora iogurte, porque meu intestino é meio parado, sabe? $\mathrm{E}$ eu não queria tomar remédio para isso... eu recebo dinheiro aqui, 20 reais por semana, as meninas quando falta tempero aqui não é remédio, né? Acho que isso não influi não, né? Eu vou para a psicóloga terça e quinta e pro CAPS eu ia segunda e... esqueci, não to indo mais, por que eu agora vou para uma psicóloga. (Ana)

Minha vida ta boa, aqui [residência terapêutica] eu alimpo a mesa, varro o chão. Eu vou no mercadinho e sei vim, chego lá digo assim: "vim aqui comprar coca-cola", levo 4 reais, que dá para comprar um refrigerante, cada um dá uma pratinha daquela de 0,50 centavo. A gente se damo bem, é sete pessoa aqui, eu tenho minha caminha. Minha saúde ta boa, boa assim...eu to sadio. To sadio é assim, to com saúde [risadas]. (Voni)

Emergem nas falas algumas das atividades cotidianas já realizadas: "eu alimpo a mesa, varro o chão"; a circulação do meio social, apontando para autonomia de vida: "vou no mercadinho e sei vim", porém, percebe-se que o passaporte para essa tão falada autonomia é o poder de aquisição de bens e consumos: "recebo dinheiro"; "levo 4 reais, que dá para comprar um refrigerante", representado, neste 
caso, pelo dinheiro que recebem do Programa de Volta para Casa (PVC), fomentado pelo Ministério da Saúde. Tal programa objetiva estimular o retorno dos egressos de longas internações psiquiátricas para sua família, bem como serve de apoio social, pois sabe-se das dificuldades de uma pessoa com sofrimento psíquico entrar para o mercado de trabalho e se tornar financeiramente ativa.

Essa questão do PVC é narrada a seguir:

Quando eu saí da unidade, eu fui para o CAPS, ai Mara e um monte de gente que tinha lá, vieram fazer meu acolhimento. Disseram que eu não precisava ir para a residência e que iam fazer um documento que vinha de Brasília para eu receber 240 reais [Programa de Volta Para Casa], dinheiro que eu pago aluguel e meu filho complementa. Muita gente recebe. Geraldo tem. A maioria que tava no Hospital recebe esse dinheiro.

Para quem eram condenados pela incapacidade de se relacionar, pela impossibilidade de conviver nos espaços sociais, sendo considerados irresponsáveis civis, as narrativas trazem outra realidade, pois os colaboradores sabem fazer contas: "dinheiro que eu pago aluguel"; decidem o que comprar: "levo 4 reais, que dá para comprar um refrigerante", o que demonstra a capacidade de viver em sociedade, além de se sentirem bem, saudáveis: "minha saúde tá boa, boa assim...eu to sadio"

A assistência ao sofredor psíquico pela lógica da Reforma Psiquiátrica tem proporcionado uma maior autonomia dos sujeitos, viabilizando uma maior circulação nos espaços cotidianos da comunidade. Configurando os serviços substitutivos como mais espaços de circulação social, de lazer e de contato com outras pessoas, como o Centro de Apoio Psicossocial (CAPS) (SANTOS JÚNIOR; SILVEIRA, 2009): 
Bom, agora eu fico participando no CAPS, a minha oficina é fuxico, que eu nem gosto, é saúde e cidadania, leitura, dança de Dr Pedro advogado. Ai, eu fico fazendo essas oficinas, só não vou para a do crochê, porque não entendo nada, não sei nem para aonde vai, meus dias são segunda, quarta e quinta-feira. Tem a piscina, mas eu não vou não, eu já fui tomar banho na piscina, mas me fizeram tanto medo dizendo que um pessoal morreu nela que eu não fui. (Jucilene)

Lá no CAPS eu participo de palestra, é fazendo desenho, fazendo coisa lá... desenho, artesanato. Eu vou no ônibus sozinho, eu ia com meu irmão, mas hoje eu sei, é o ônibus 555 e para voltar eu apanho o ônibus 505 na frente da rodoviária. Tem um bucado de doida lá, mas eu não quero nenhuma não, é tudo feia. Ah, uma galega daquelas que trabalha lá dava pra viver. Hoje minha vida ta muito boa graças a Deus, primeiramente Deus, depois ela [cunhada], porque agora eu to no céu e de primeira eu não tava não. Eu gosto daqui, eu quero assistir televisão tenho, quero comer tenho tudo, não falta nada, tudo é fartura pra mim aqui, eles me tratam que nem que seja um filho deles. Minha saúde ta boa hoje, para a vista que era ta boa, porque eu não tive mais crise, não da mais vontade de andar como eu andava. Meu tratamento é tomar o remédio e ir de $15 \mathrm{em}$ 15 dias na médica. Eu não faço nada, só faço dar caminhada pelo Zé Pinheiro [bairro onde mora], comer e dormir. Vou na casa de uma amiga, tomo um café converso... tomo a medicação sozinho sem derrubar, antes tinha que dar na boca. (José) 
Devido à prática de segregação e exclusão do sofredor psíquico, todas as atividades realizadas devem ter como objetivo central promover a reinserção social: "eu fico participando no CAPS"; proporcionando-lhes autonomia: "eu vou no ônibus sozinho"; através do processo de reabilitação psicossocial, com reaprendizagem de atividades cotidianas e sociais necessárias para a vida em comunidade. Para tal, são tomadas como recursos de alto valor terapêutico as formas universais de lidar com problemas como a amizade: "vou na casa de uma amiga"; a religião e o entretenimento: "só faço dar caminhada". Percebe-se que se trata de reinventar a vida em seus aspectos mais comuns, pois é principalmente do cotidiano da cidade que se encontram privados os sofredores psíquicos.

\section{Então, as histórias foram rememoradas...}

Foi com o olhar sobre o processo saúde-doença mental, na perspectiva antropológica e etnográfica, que partimos para executar este estudo, e foi com ele que chegamos às considerações ora apresentadas, acerca dos resultados encontrados.

Esta pesquisa etnográfica possibilita o conhecimento a respeito da atenção à saúde mental, pois os colaboradores que vivenciaram o tratamento hospitalar e hoje estão inseridos nos serviços extra-hospitalares, narram suas trajetórias individuais, eventos e processos que, muitas vezes, foram o que culminou no seu adoecimento e na determinação de sua "carreira" como "doente mental", portanto, passível do poder psiquiátrico. Além de que possibilitou retirar das sombras e dar voz ao segmento social da "doença mental", que embora faça parte da História, esteve (ou ainda está) dela marginalizado por muito tempo.

Há que se frisar que as estórias de vida apresentam uma grande quantidade de dados primários, os quais permitem, além de descrições precisas da situação estudada, ilustrar a perspectiva dos 
colaboradores, isto é, as suas maneiras de ver o mundo e suas próprias ações e consequências.

Por isso, pois, refletimos que quando se propõe o fim dos manicômios, não é apenas a "derrubada" de um prédio ou dos seus muros, mas sim na forma como lidamos com as pessoas em desvantagens sociais, que não permite a diferença, afinal, ninguém escolhe ficar "louco"!

\section{Referências}

AMARANTE, P. Saúde mental e atenção psicossocial. Rio de Janeiro: Fiocruz, 2007.

BRASIL. Ministério da Saúde. Secretaria de Atenção à Saúde/DAPE. Saúde mental no SUS: acesso ao tratamento e mudança no modelo de atenção. Relatório de Gestão 2003-2006. Brasília: Ministério da Saúde, 2007.

GEERTZ, C. A. Interpretação das culturas. Rio de Janeiro: Livros Técnicos e Científicos, 1989.

GOFFMAN, E. Manicômios, prisões e conventos. $7^{\circ}$ ed. São Paulo: Perspectiva, 2003.

GUALDA, D. M. R.; BERGAMASCO, R. B. Processo saúde-doença: evolução de um conceito. In: GUALDA, D. M. R.; BERGAMASCO, R. B. (Orgs). Enfermagem, cultura e o processo saúde-doença. São Paulo: Ícone, 2004. p. 25-37.

GUALDA, D. M. R. Eu conheço minha natureza: a expressão cultural do parto. Curitiba: Maio, 2002. 
HEILBORN, M. L. Gênero e condição feminina: uma abordagem antropológica. In: INSTITUTO BRASILEIRO DE ADMINISTRAÇÃO MUNICIPAL. Mulher e políticas públicas. Rio de Janeiro, 1991.

MINAYO, M. C. S. O desafio do conhecimento: pesquisa qualitativa em saúde. 6 Ed. São Paulo: Hucitec, 1999.

SANTOS, A. C. A. Fontes orais: testemunhos, trajetórias de vida e história. Departamento de História Universidade Federal do Pará. Revista Via Atlântica, v. 4, p. 1-10, 2000.

SANTOS JÚNIOR, H. P. O.; SILVEIRA, M. F. A. Práticas de cuidados produzidas no serviço de residências terapêuticas: percorrendo os trilhos de retorno à sociedade. Rev esc enferm USP, v. 43, n. 4, p. 788-795, 2009.

SOARES, S. R. R.; SAEKI, T. O centro de atenção psicossocial sob a ótica dos usuários. Rev Latino-am Enferm, v. 14, n. 6, p. 105-112, 2006. 


\title{
Residências Terapêuticas e Reforma Psiquiátrica em produções discursivas da população
}

\author{
Thelma Maria Grisi Velôso \\ Pedro de Oliveira Filho \\ Élida Dantas do Nascimento \\ Pauleska Asevedo Nóbrega \\ Roseane Barros Pinto
}

\section{Introdução}

As propostas de saúde pública que surgiram no bojo das discussões promovidas, nos anos 70, pelo movimento de transformação da saúde pública nacional, a chamada Reforma Sanitária, convidam à reflexão e à investigação científica. Com esse propósito, pretende-se, neste texto, ampliar a discussão sobre a proposta de Reforma Psiquiátrica no Brasil.

As críticas feitas à Psiquiatria Asilar desembocaram no desmantelamento de uma estrutura que oprimia, controlava, punia, vigiava e segregava os chamados loucos no interior das organizações manicomiais. Nesse sentido, a "desinstitucionalização não se restringe à reestruturação técnica, de serviços, de novas e modernas terapias: torna-se um processo complexo de recolocar o problema, 
de reconstruir saberes e práticas, de estabelecer novas relações" (AMARANTE, 2007).

No Brasil, o movimento de combate à psiquiatria asilar se materializou através da Lei de Reforma Psiquiátrica (Lei 10.216/2001), cujo objetivo fundamental é o resgate da liberdade e do direito à cidadania das pessoas classificadas como loucas. Por essa razão, seguindo, sobretudo, a proposta da Psiquiatria Democrática Italiana, manicômios foram fechados, e novos espaços foram criados - o chamado modelo substitutivo, baseado na criação de centros de saúde mental, serviços abertos e extra-hospitalares na comunidade, e que servem como referenciais nos momentos de crise. Criaram-se também as residências terapêuticas, uma alternativa para aqueles que, com o fechamento dos manicômios, perdem os vínculos com a família e necessitam de condições para reconstruir os laços sociais. Essas residências se localizam no espaço urbano e são habitadas por, no máximo, oito moradores, objetivando promover sua reabilitação psicossocial e inseri-los na comunidade (BRASIL, 2004).

A inserção dos denominados loucos na comunidade é, como vimos, um dos objetivos explícitos das residências terapêuticas. Não é uma tarefa simples, pois se sabe que um dos maiores obstáculos para a plena cidadania dos denominados loucos, no mundo ocidental, são os discursos sobre a loucura, que se reproduzem, há séculos, no cotidiano das sociedades ocidentais. Por essa razão, é extremamente relevante saber se e como esses discursos estão sendo mobilizados na sociedade brasileira, quando as residências terapêuticas começam a fazer parte da nossa paisagem urbana.

Este trabalho procura dar uma pequena, mas significativa contribuição a respeito desse aspecto. Para isso, tenta responder à seguinte questão: Quais os sentidos produzidos pelas pessoas que moram nas proximidades das residências terapêuticas, em Campina Grande-PB, sobre essas residências e as pessoas que nelas habitam? 
Propusemo-nos a estudar a produção de sentidos com base em uma ampla perspectiva teórica da psicologia social, que vem destacando o papel da linguagem na produção da vida social (SPINK; FREZZA, 1999; POTTER, 1998; WETHERELL; POTTER, 1992; POTTER; WETHERELL, 1987; GERGEN, 1985).

$\mathrm{Na}$ história da psicologia social, é notório o papel atribuído à linguagem na constituição dos processos psicossociais. No entanto, ela tem sido vista predominantemente pelos teóricos que fizeram a história dessa disciplina como um meio neutro, cuja única função é expressar pensamentos, sentimentos e outras entidades psicológicas. Mas, nas últimas três décadas, a psicologia social vem dando lugar ao reconhecimento do papel fundamental da linguagem e do discurso na construção do psiquismo humano e das relações sociais. No contexto acadêmico atual, uma consequência desse processo é a existência de um conjunto de abordagens discursivas na psicologia social, que se fundamentam, epistemologicamente, no construcionismo, lutando e se posicionando de maneira crítica em relação às abordagens tradicionais.

Nessa perspectiva, um pressuposto central é a ideia de que usar a linguagem é uma forma de ação como qualquer outra. Assim, quando construímos versões sobre o mundo, quando argumentamos, descrevemos, narramos, explicamos etc, estamos realizando ações (SPINK; FREZZA, 1999).

As abordagens discursivas são marcadamente anticognitivistas, enquanto as abordagens cognitivistas compartilham da noção de representações mentais internas e entendem a cognição como anterior à linguagem e esta última como o meio através do qual a cognição se expressa, as abordagens discursivas procuram destacar o modo como a linguagem constitui formas de experienciar o mundo (AUGOUSTINOS, 1995).

Neste texto, o interesse pela análise dos sentidos produzidos discursivamente sobre as residências terapêuticas e seus habitantes é 
uma decorrência do pressuposto de que tais sentidos constituem a experiência desses sujeitos e de seus interlocutores sobre esses objetos sociais.

Portanto, compreender esses sentidos certamente nos dará indicações sobre as tensões, as contradições e as possíveis resistências que marcam o diálogo desses sujeitos com discursos e instituições ligados à reforma psiquiátrica brasileira.

\section{Metodologia}

Em Campina Grande, o processo de Reforma Psiquiátrica materializa-se, atualmente, na existência de uma Unidade de Referência em Saúde Mental; um Centro de Convivência de Artes e Ofícios; seis residências terapêuticas e cinco Centros de Atenção Psicossocial (CAPS), sendo que um deles, o CAPS ad, atende, exclusivamente, a usuários de álcool e de outras drogas, e outros dois são CAPS-i para atenção infanto-juvenil.

Desenvolvemos uma pesquisa qualitativa e recorremos à metodologia qualitativa da História Oral como estratégia de geração de dados. Para isso, foram obtidos 24 (vinte e quatro) depoimentos orais - onze de entrevistados do sexo masculino e treze do sexo feminino - cujas idades variam de 22 a 78 anos - que moram próximos às residências terapêuticas, três das quais são masculinas (uma localizada no Bairro das Nações, uma, no Cruzeiro, e outra, no Centro), uma mista (localizada no Bairro das Nações), e duas femininas (localizadas no Bairro do Alto Branco), onde moram os usuários egressos do Instituto Campinense de Neuropsiquiatria e Reabilitação Funcional (ICANERF), que foi desativado em 2005.

O número de entrevistados foi delimitado pelos critérios de acessibilidade e do ponto de saturação. Este último indica que já se dispõe de informações suficientes sobre determinado aspecto, pois 
a análise acompanha todo o processo de pesquisa e permite que constatemos, nas entrevistas, uma repetição dos conteúdos, indicando que já podemos encerrar a coleta de dados após a obtenção de mais algumas entrevistas (LANG; CAMPOS; DERMATINI, 2001) e recorremos à técnica de análise do discurso, desenvolvida por psicólogos sociais de orientação discursiva (WETHERELL; POTTER, 1992; POTTER; WETHERELL, 1987).

\section{Os sentidos construídos nos discursos}

Segundo Resende (2000), na realidade, a finalidade social dos hospitais psiquiátricos era a de serem verdadeiros depósitos humanos, que nada tinham de terapêuticos. A fala de David, abaixo, reitera essa ideia, entretanto, transfere essa definição dos hospitais psiquiátricos para as residências terapêuticas:

Eu acho... Penso eu (ênfase) como os familiares não têm condições de ficar, com... eles, em casa, e... como eram... vieram de... de... do hospital que fechou. (...) Eu soube que é uma forma de... de... não sei se, estaria certo meu termo, um depósito de doentes, né? Pra tirar (ênfase) do convívio da família, pra... ficar aí, né? (...) As pessoas que não ficam com ele em casa, porque até mesmo acho que tem certos... certos doentes mentais que não... têm mesmo como conviver em casa mesmo com a família, e são... colocados aí... (David 4, 41 anos; há vinte e oito anos reside no Bairro Alto Branco - vizinho da residência terapêutica)

4 Para garantir o anonimato dos entrevistados e demais pessoas citadas nos discursos, foram utilizados pseudônimos. 
David adota, nas suas palavras, um tom dubitativo, em relação ao modo de qualificar as residências terapêuticas, embora não o comprometa tanto com aquilo que é afirmado, termina por posicioná-lo para o interlocutor como alguém atualizado com certo vocabulário crítico. Se o que ele afirma "soube" de alguém, se ele não está bem certo da adequação do termo "depósito de doentes", é ele, de qualquer forma, que está usando o termo em questão.

Esse discurso indica que, apesar da crescente visibilidade da proposta preconizada pela Reforma Psiquiátrica, com a desospitalização, os termos e as metáforas usados para descrever e interpretar os hospitais psiquiátricos continuam sendo usados e, ironicamente, para descrever uma instituição que o discurso reformista apresenta como a antítese da psiquiatria asilar. Elas aparecem, na sequência discursiva acima, como instituições que substituem os hospitais simplesmente porque eles "fecharam". Nenhuma diferença entre as duas entidades é citada; a residência é descrita como se tivesse as mesmas funções do hospital psiquiátrico.

Em sua fala, David, além de não diferenciar as residências dos hospitais, também justifica a sua suposta função de separar da família e da sociedade "certos doentes mentais" com os quais não se pode "conviver", reproduzindo uma velha compreensão da loucura na qual os loucos, em família, eram considerados um "perigo solto" (PEREIRA, 1983).

Já no discurso de Márcia, a seguir, a residência terapêutica assume sentidos totalmente diferentes do apresentado por David:

A residência? Eu... eu acho que é um asilo de velho.(...) Eu acho que é... assim... eu vim descobrir agora a pouco que era isso, sabe? Porque... passava lá via gritos... essas coisas assim.(...) Aí um dia eu encontrei uma moça que vinha com uma velhinha dali, sabe? E a velhinha, gritando com ela... aí eu disse assim: "Meu Deus o que será aí essa casa?” Todo dia eu passava pra 
levar a menina no colégio e escutava gente... gritando... coisas estranhas...(...) Aí eu falei assim, eu disse assim: "Dona Paula eu acho que isso aqui é um asilo de velho..." aí... quando foi um dia... aí, tem um buraco lá na porta... aí... eu olhei...aí...um monte de velho...aí... ia saindo uma senhora de lá...aí eu disse assim: "Isso aí é o quê??" Aí... ela disse assim: "É um asilo." Eu disse: "É um asilo?" Uma casa assim sem nome e sem nada, né?(...) Ai eu cheguei em casa e falei com a minha patroa. (...) Ai ela disse assim: "É um..." Eu disse assim: "Dona Paula é um asilo, mas como tem um asilo assim sem ter nada?." Aí.. ela disse: "Deve ser clandestino..." Aí a partir desse dia eu vejo carro saindo de lá com um velho da Secretaria da Saúde e... ambulância pra tirar eles daí pra ir pra hospitais... assim o que eu sei é isso... eu acho que é... passa tanto velho ali junto... e é um casarão... e é um casarão como esse, né? Deve ter vários quartos (...) Vem... eu já vi... várias... vem... gente visitar (pausa) eu num sei se é particular também, né? (...) Pode ser até uma casa particular que eles pagam pra ficar, né? num tem? Uma tipo... casa de repouso. (...) uma casa de repouso... eu acho... e muito mal... organizada, né? Não é divulgada. (...) Não. Porque... eu vim morar aqui, eu vim saber que tinha essa casa depois de uns seis meses que eu estava aqui... (...) Como a casa de apoio aí também que tem... que foi... foi uma boa iniciativa também e eu não sabia. (...) são coisas que fazem e não divulgam, né? Até porque se você... tiver que indicar a alguém você nunca vai saber... Se não é divulgado... Se, se... a gente não tom... não tem acesso ao que acontece. (Márcia, 48 anos; há dois anos reside no Bairro Alto Branco - sua residência dista três casas da residência terapêutica) 
Seu discurso, como o de David, denota também um tom de dúvida. No entanto, o objeto de dúvida expresso por Márcia é a expressão a ser usada para qualificar os moradores da residência. Nesse discurso, a natureza da instituição e a identidade dos moradores são incertas: "A residência? Eu... eu acho que é um asilo de velho".

A identidade que ela apresenta para aqueles que habitam as residências se distancia, num primeiro momento, daquilo que eles são nos discursos das instituições psiquiátricas e da sociedade. São "velhos", não são "doentes mentais", "loucos”, ou qualquer termo classificatório de origem psiquiátrica.

Assim, à medida que prossegue seu depoimento, os termos utilizados para descrever as residências terapêuticas vão se alterando. São apagadas as referências aos habitantes da casa ("essa casa", "asilo", "casa de repouso"), que vai se tornando cada vez mais misteriosa; uma casa de funções indefinidas, onde ocorrem "coisas estranhas". Uma casa que se torna estranhamente próxima daquilo que se supõe ser o universo da loucura. Sem citar um só termo do vocabulário psiquiátrico usado para descrever o sofrimento psíquico, Márcia, involuntariamente, descreve a residência de sua comunidade de uma maneira que a deixa estranhamente parecida com a imagem construída no Ocidente para descrever o universo da loucura. A residência é retratada como um lugar enigmático, onde há desespero, confusão, onde ocorrem "coisas estranhas".

A opinião de Márcia, assim como a de outros entrevistados, caracteriza-se, principalmente, pelo fato de indicar que as residências estão segregadas em relação ao próprio espaço no qual estão inseridas, porquanto não se sabe muito bem o que realmente são. Esses discursos apontam para o isolamento da residência terapêutica em relação ao espaço circundante.

O termo “casa de repouso" utilizado por Márcia também é utilizado por Aparecida. Todavia, na entrevista de Márcia, os usuários da 
casa de repouso não são nomeados de maneira inequívoca ao longo de toda a sua fala (no início, são os "velhos", mas depois, podem ser qualquer categoria social). Já para Aparecida, a casa de repouso é inequivocamente um local para "doentes mentais", como podemos constatar nesta sequência discursiva:

Eu acho o seguinte: que essas casas, que são várias não são, né? Uma só, eu acho que eles deviam assim botar ou construir ou arranjar uma casa grande pra botar essas digamos, três quatro residências alugadas, tá uma só e cuidar deles ali como (pausa) como uma casa de repouso, né? Eu acho isso. (...) Sim, e com terapias para eles que são doentes mentais, né? (Aparecida, 60 anos; há cinco anos, reside no Bairro Alto Branco - reside do lado oposto da residência, passando três casas)

Aparecida se distancia explicitamente da concepção de residência terapêutica defendida pela Reforma Psiquiátrica, que ela encontra materializada em seu bairro. A concepção desenhada por ela se aproxima mais do modelo hospitalocêntrico, em que uma grande quantidade de pessoas se encontra internada em um mesmo lugar.

Já no retrato das residências produzido por Henrique, a identidade dos seus habitantes se torna mais heterogênea do que nas falas dos sujeitos supracitados, e diferentes categorias de pessoas são citadas: pessoas que vivem "abandonadas", "pessoas de idade", "doentes mentais":

É um tratamento que cuida das pessoas, deve ser alguém assim abandonado, vive ai (...) é uma casa, assim, que recupera as pessoas né? São pessoas que vivem abandonadas, pessoas de idade, doentes mentais, como um refúgio para eles, assim, porque eu acho que a família 
deve abandonar, colocar eles ai, esquecem, né? Ainda bem que tem gente que toma conta deles ai, né? Não sei quem é que faz isso ai, mas acho que é um projeto bom isso aí. (Henrique, 34 anos; reside, há um ano, no Bairro Alto Branco, vizinho à Residência terapêutica)

Henrique expressa que a residência não é um lugar por meio do qual as pessoas estabelecem novas relações sociais em suas comunidades. É um “refúgio” que vai protegê-las, mas também isolá-las do mundo exterior, um lugar extremamente semelhante à imagem dos hospitais psiquiátricos construída historicamente, para pessoas "abandonadas", "esquecidas", estorvos familiares.

Se o louco é concebido como alguém incapaz de exercer a cidadania, o isolamento, então, é um recurso necessário para retirá-lo de um estado confuso e desordenado, internando-o numa instituição disciplinar, na qual é submetido ao "tratamento" (AMARANTE, 1995).

Assim como Henrique, Alberto também aproxima simbolicamente as residências terapêuticas dos hospitais psiquiátricos ao descrevê-las como um abrigo para pessoas "abandonadas" e com "doenças mentais":

É uma residência que abriga pessoas com doenças mentais, pessoas que foram abandonadas. Pessoas que não tem ninguém (...) Que não tem uma pessoa na sua família, mas sofre de uma doença, muitas vezes não quer tratar, não quer deixar em casa e o que é que faz? Põe numa casa como essa. (...) Antes de eu vir pra aqui ela já existia. É uma casa normal, mas não tem como você olhar assim e dizer: "Ali é uma casa de pessoas com problemas... Normal”. É, a... aparentemente normal, por fora. (Alberto, 22 anos; reside, há três anos, no bairro Cruzeiro do lado oposto da rua, passando três casas) 
Os habitantes das residências, tal como os pacientes psiquiátricos, são rejeitos sociais. Pessoas que as famílias não querem mais e colocam "numa casa como essa". A residência, nesse discurso, é uma casa "aparentemente normal por fora", mas habitada por "pessoas com problemas", pela anormalidade, pela desrazão.

No depoimento de Jéssica, abaixo, a imagem da residência como um espaço da desrazão se acentua mais ainda, e ele se torna cada vez mais um hospital psiquiátrico em miniatura.

É... um... lugar... onde as pessoas, que têm dificuldades mentais (silêncio) ficam e... devem (ênfase) ter assistência... (...) É... a meu ver um abrigo é... esses, é uma proteção tanto pros doentes... mentais, como pra vizinhança (...). Porque se um doente mental ele não fizer um tratamento e não estiver num lugar adequado onde tiver um tratamento, ele... se descontrola... (Jéssica, 48 anos; há um ano, reside no Bairro Alto Branco - a duas casas da residência)

A residência é um "abrigo" que protege tanto a população comum do descontrole do "doente mental" quanto o próprio "doente mental”, de seu próprio descontrole.

Ao longo do depoimento de Jéssica, um sutil deslizamento semântico muda a imagem das residências apresentada acima. Em um tom acusatório, ela afirma que a residência é um "depósito de doentes", onde as pessoas não recebem tratamento adequado, e não, um espaço de isolamento da desrazão:

Pra mim aí não é um abrigo de, de tratamento... de doente mental não. Pra mim aí era uma casa que eles deixavam os doentes, vinha comida e... davam... e pronto! (Jéssica, 48 anos; há um ano, reside no Bairro Alto Branco - a duas casas da residência). 
Em outras opiniões, a residência é concebida como um espaço de tratamento, de apoio e recuperação de pessoas com "deficiência mental", sem que se mencione explicitamente a função de isolamento, de separação da comunidade.

É uma casa de apoio. Tem uma... de apoio, né? Pras pessoas se recuperar... (...) que tá precisando de apoio, né? (...) Pesquisadora: Para pessoas com... Com deficiências mentais, né? (Larissa, 29 anos; há quatro anos, reside no Bairro Cruzeiro - do lado oposto da rua, passando duas casas da residência terapêutica).

Pesquisadora: Uma residência terapêutica é uma casa de...

De recuperação.

Pesquisadora: Uma casa de recuperação. E nessa casa de recuperação...

Entrevistado: Ela é só feminina. (Ronaldo, 58 anos; Há oito anos, reside no Bairro Alto Branco - vizinho da residência terapêutica).

Só um abrigo, né? Pra pessoas que têm deficiência mental. (Pierre, 26 anos; há três anos, reside no Bairro das Nações - em frente à residência terapêutica).

Para Larissa, a residência terapêutica é "uma casa de apoio" para as pessoas com deficiência mental, onde elas podem "se recuperar". O discurso de Ronaldo retoma o viés da fala de Larissa, ao enfatizar também que a residência terapêutica é um local de "recuperação". Já Pierre limita a proposta das residências a ser "só um abrigo" destinado às pessoas portadoras de deficiência mental.

Nas falas de Ana, Sônia e Talita, abaixo, a residência continua a ser apresentada, implicita ou explicitamente, como um espaço de tratamento psicológico e médico, mas novos termos, mais ambíguos, 
indefinidos, "suaves" são usados para nomear os seus residentes: "pessoas com problema", "pessoas que precisam", "pessoas com esse tipo de problema":

Não... (ênfase)... isso não é divulgado. (...) Eu vim tomar conhecimento, porque (ênfase) alguém perguntou... chegou aqui, bateu na minha porta e perguntou: "Onde é a casa... de pessoas com problema?" (...) "eu não sei nem se existe (risos) aqui nessa rua". Quer dizer, é uma coisa que não é divulgada. (Ana, 51anos; há um ano e meio, reside no Centro - do lado oposto da residência terapêutica passando quatro casas)

É uma casa de fazer terapia, né? (...) É a única coisa que eu sei. (...) Eu acho que é uma casa de ajuda pra quem precisa, né? (...) Uma casa de terapia para pessoas que precisam daquele movimento. (Sônia, 78 anos; há quinze anos, reside no Bairro Alto Branco - reside numa rua transversal à rua da residência terapêutica)

É uma residência onde eles acolhem essas pessoas com esse tipo de problema pra fazer um tratamento, um acompanhamento (...) Como tratamento médico, psicológico. Acho que, que engloba tudo (...) um lugar que eles vão ser bem acolhidos, bem tratados... (...) Eu imagino que seja um lugar bom (risos) (...) que a família dessas pessoas não tiveram é... (pausa) como tratar delas, não sabiam como fazer assim... num momento assim... que eles procuraram esse lugar pra ter uma ajuda, pra dá uma ajuda pra essas pessoas, porque eles não sabiam como fazer. (Talita, 25 anos; há sete anos, reside no Bairro Alto Branco - Terceira casa depois da residência) 
A residência é também construída discursivamente como um local destinado a acolher pessoas de baixa renda, "carentes", "necessitadas", "deserdadas":

É como eu tô dizendo, eu acho que do jeito que está essa casa aqui, eu tenho certeza que as outras também tão... não sei lhe dizer quantas casas são... distribuídas aqui na cidade, mas eu sei que aqui no Alto Branco tem uma, e ali em cima tem outra... agora a rua eu não sei dizer, mas sei que são duas casas só no Alto Branco... para atender essas pessoas carentes e necessitadas. (Amanda, 40 anos; há dezessete anos, reside no bairro Alto Branco - vizinha da residência terapêutica)

Olha, pra mim é um acolhimento (...) Essa residência pra mim é um lar, é um abrigo de amparo a essas pessoas deserdadas da sorte (...) A dormida tudo é aí... é como se fosse o lar deles. (José, 67 anos; há dezesseis anos, reside no bairro do Cruzeiro - do lado oposto da residência terapêutica, passando uma casa)

A ideia de abrigo que aparece em outros discursos, como vimos, consolida-se nas falas acima, que ressaltam o caráter de assistência das residências, considerando-as como lugares para pessoas carentes e necessitadas. José enfatiza outro aspecto que merece ser destacado: o fato de que a residência é "um acolhimento", "um lar" "um abrigo de amparo". É "como se fosse o lar deles", e se é "como se fosse", não é o lar deles. A residência, então, seria uma invenção. Algo que tenta reproduzir uma relação familiar, mas que não é capaz de fazê-lo, o que nos remete à questão do tipo de abrigo como "o lar dos velhinhos". 
Numa mudança considerável, em relação às falas anteriores, o termo CAPS é usado em alguns depoimentos para nomear a residência, como expressam os trechos seguintes:

$E$ E, assi... eu... eu... assim, pessoalmente eu não frequento muito (...) Sei que, tem assim essas casas de yoga, essas coisas assim, mais terapêutica assim, mais específicas, não (...) Eu não, realmente eu não... eu sei que existe assim... é... casa de yoga, essas coisas, aqui, aqui tem o quê... tem, o pessoal que faz hidroginástica, esse tipo de coisa né? assim, mas (pausa) qual o tipo de terapia mais específica, porque tem o CAPS ali em baixo também, né? (...) É... assim, de certa maneira o CAPS hoje, veio fazer com que... tivesse... um... uma maior... assim atenção, pra esse tipo de, de, de... pessoal né? que necessita de ajuda, tudo, que antes, não... tinha, tinha que... se (ênfase) a família tivesse condições, fazia isso numa clínica particular, esse tipo de coisa né? (Gabriel, 25 anos; há vinte e cinco anos, reside no bairro Alto Branco - na rua transversal, passando cinco casas da residência terapêutica)

O que eu acho... é uma iniciativa muito boa... do governo federal junto com a prefeitura. É o CAPS no caso, eu acho muito bom, as famílias acham muito bom também, porque esse é um meio que elas tem de manter esse paciente em casa. Eles tem tratamento psicológico, tem tratamento com medicamentos correto. $E$ aí eles tem uma boa alimentação, tem um acompanhamento, tem uma área de lazer que eles participam, tem todo um acompanhamento que eu acho muito bom, essa residência terapêutica. (...) Tinha alguns que estavam ali... onde fechou, no João Ribeiro [refere-se ao 
Instituto Campinense de Neuropsiquiatria e Reabilitação Funcional(ICANERF), que foi desativado na cidade de Campina Grande] aí... foram transferidos para a casa terapêutica. (...) E alguns de doutor Maia também. (...) Não só pra esse aqui, pois tem vários CAPS aqui em Campina. (Andréia, 22 anos; há 20 anos, reside no bairro do Cruzeiro - uma casa depois da residência terapêutica)

Pessoas que convivem, né? No CAPS aí. (...) É (...) Pelo menos aparentemente. No dia que eu fui lá (pausa) é como se fosse uma residência normal. (...) Uma pessoa sentada na mesa... conversando. Os funcionários tratando como se fosse... sei lá... pessoas da família. O que eu pude notar é isso. Não tem, agressão física, violência... não tem... eles não impedem da, dos... do pessoal ir e vir, sair da residência quando eles quiserem. (Júlio, 29 anos; há 15 anos, reside no bairro Alto Branco - reside numa rua transversal à rua da residência terapêutica)

(...) Às vezes a gente passa aí na frente dá pra ver a sala de TV... todas as vezes que eu passo eles estão bem quietinhos assistido televisão (...) São... assim, por ser uma residência, né? Não tem como você escolher uma residência num lugar que não seja um bairro, uma rua, um lugar que tem outras casas, né? Eu acredito que a intenção quando se criou essa história de CAPS, acho era isso... achar uma residência, uma coisa, né? Informal assim e que passe... que tenha pra passar pros enfermos uma qualidade melhor de vida. Eu acredito que... tá tudo correto (pausa) não poderia ser diferente. Acredito. (...) Pelo que me informam é um CAPS, né? (...) Isso aí é o CAPS. (...) Acredito o que qualquer uma pessoa poderia pensar. É um... uma... 
unidade de... de terapia para pessoas com problemas mentais, num é? É... patrocinado pelo... pela prefeitura... (Roberto, 29 anos; há 25 anos, reside no bairro Alto Branco - duas casas depois da residência terapêutica)

Embora Gabriel empregue o termo CAPS, não há qualquer outra aproximação mais clara com o universo discursivo da reforma psiquiátrica. A casa é um local para pessoas que necessitam de "ajuda".

A fala de Andréia, por outro lado, aproxima-se, em termos de conteúdo, do discurso reformista, porquanto enfatiza que o objetivo do "CAPS" é "manter esse paciente em casa". Diferentemente de discursos ouvidos anteriormente, aqui, a ideia de separar o "paciente" da comunidade não só está ausente, mas também é implicitamente combatida na medida em que se elogia a permanência do paciente junto da família.

Gabriel, Júlio e Roberto também usam o termo CAPS para falar da residência terapêutica de seu bairro. Seus discursos, de maneira mais consistente e articulada do que o de Andréia, mobilizam termos do vocabulário da Reforma e combatem o modelo hospitalocêntrico. Esse modelo é combatido sem que seja citado explicitamente.

As características do novo modelo, citadas em seus discursos, são contrárias às do modelo asilar. Nas residências, "não tem agressão física, "violência", as pessoas podem "ir e vir", "sair da residência quando eles quiserem". As "pessoas" (no discurso de Júlio) ou os "doentes mentais" (no discurso de Roberto) são tratados como os outros cidadãos. Como que dialogando com discursos que expressam incômodo pela presença da residência em seu bairro, Roberto afirma que ela é assim "por ser uma residência”. E continua: "Não tem como você escolher uma residência num lugar que não seja um bairro, uma rua, um lugar que tem outras casas, né?" 
Os discursos de Glória, Andréia, Júlio e Roberto mobilizam termos e expressões do discurso reformista e citam, explicitamente e diferente desses últimos, a reforma psiquiátrica ("essa Reforma”).

Eu acho que é a modernização da... da... do tratamento do... das pessoas com... com... enfermidades mentais, que... evoluiu de... de dar choques, né? evoluiu de... de isolar, segregar, é uma evolução muito grande, eu acho que é um ponto extremamente positivo no tratamento dos doentes. (...) achei que foi um avanço da psiquiatria... ou talvez da psicologia, acho que mais da psiquiatria, né? Achei que foi um avanço enorme, enorme no tratamento (pausa) e eu acho acho muito (ênfase) positivo porque eles moram em casa, tem as empregadas, tem o vigia, a família vem sempre (ênfase) aí, eles, eles passeiam, levam eles numa... tem uma combe levam eles pra passear, pra visitar a família, a família vem... tem uns que os pais vêm diariamente dar banho... tudo (...) deve ser essa Reforma, deve ser isso, um tratamento humanizado, e tirar... daquele... onde eles ficavam naquele isolamento, colocar numa residência, dar a ele um... um.... um... um... um aspecto de lar (ênfase)... eles tem aí... é uma casa é um lar (...) é um lar porque tem tudo que você... (...) Porque se você entrar aí você vê olha o que tem... tem televisão...(...) Pra eles tem jogo, eles jogam totó (...) é uma casa, com quarto, com tudo (...)" (Glória, 67 anos; há mais de trinta anos, reside no Bairro das Nações - do lado oposto da residência terapêutica, passando uma casa). 
De maneira mais evidente do que aparece nos discursos de Andréia, nas falas de Júlio e de Roberto, esses termos se misturam com outros do discurso psiquiátrico tradicional.

Para ela, diferentemente do modelo anterior, o modelo implantado pela reforma não isola, não segrega as pessoascom "enfermidades mentais", "doentes". Em outros momentos, no entanto, afirma que é um avanço da "psiquiatria", quando se sabe que se pretende "antipsiquiátrica", e usa a ambígua expressão "tratamento humanizado", expressão incômoda para o discurso reformista, por sua associação com o argumento da psiquiatria tradicional, segundo o qual a instituição hospitalar poderia ser preservada, desde que se tornasse "mais humana".

Assim como José, Glória ressalta, ainda, como já citado, o "aspecto de lar" da residência (os passeios, visitas, etc.), bem como o que existe em seu interior, aquilo que, para ela, faz dela "uma casa", "um lar" (quarto, televisão, jogos).

\section{Considerações finais}

Neste texto, apresentamos parte dos resultados de uma pesquisa que realizamos sobre os sentidos atribuídos às residências terapêuticas pela população dos bairros onde essas residências estão localizadas em Campina Grande/PB. Essa pesquisa se desenvolveu através de uma proposta que privilegia o estudo da produção de sentidos por meio da análise das práticas discursivas.

Com base nas análises dos depoimentos dos entrevistados, podemos referir que diferentes sentidos são construídos para as residências terapêuticas, o que demonstra, em alguns casos, que há um distanciamento da proposta da Reforma Psiquiátrica e, em outros, uma aproximação gradativa dessa proposta. Assim, a residência é concebida como "depósito de doentes", "asilo de velho", "casa de 
apoio/repouso, pessoas com problema, pessoas carentes”, “auxílio psicológico, acolhimento e abrigo de amparo" e como o "CAPS".

O fator doença aparece, sobremaneira, nos discursos como responsável pela impossibilidade de um convívio social, ou seja, como uma "deficiência" que resulta no isolamento desses sujeitos. O caráter assistencial das residências é reiterado em muitos discursos.

No contexto da Reforma Psiquiátrica, deparamo-nos com discursos que, em geral, reproduzem sentidos vinculados às antigas práticas asilares. Isso serve de alerta para os grandes desafios que ainda precisam ser enfrentados no processo de concretização dessa proposta.

\section{Referências}

AMARANTE, P. A (clínica) e a Reforma Psiquiátrica. Curso de Especialização em Saúde Mental e Atenção Psicossocial. Campina Grande: FIOCRUZ/UEPB, 2007.

. Uma aventura no manicômio. História, Ciências, Saúde Manguinhos, v. 2, n. 1, p. 61-77, 1995.

AUGOUSTINOS, M.; WALKER, I. Social Cognition: an integrated introduction. London: Sage Publications, 1995.

BRASIL. Ministério da Saúde. Secretaria de Atenção à Saúde. Residências Terapêuticas: o que são, para que servem. Brasília: Ministério da Saúde, 2004.

GERGEN, K. J. The Social Constructionist Movement in Modern Psychology. American Psychologist, v. 40, n. 3, p. 266-275, 1985. 
LANG, A. B. S. G.; CAMPOS, M. C. S. S.; DERMATINI, Z. B. S. História oral e pesquisa sociológica: a experiência do CERU. $29^{\circ}$ ed. São Paulo: Humanitas, 2001.

PEREIRA, J. F. O que é loucura. 2 a ed. São Paulo: Brasiliense, 1983.

POTTER, J. La representación de la realidad: discurso, retórica y construcción social. Barcelona: Paidós, 1998.

POTTER, J.; WETHERELL, M. Discourse and Social Psychology: beyond attitudes and behavior. London: Sage Publications, 1987.

RESENDE, H. Política de saúde mental no Brasil: uma visão histórica. In: ALMEIDA, S. T.; COSTA, N. (Orgs.). Cidadania e loucura: políticas de saúde mental no Brasil. $6^{\circ}$ ed. Rio de Janeiro: Vozes, 2000.

SPINK, M. J.; FREZZA, R. M. Práticas discursivas e produção de sentidos: a perspectiva da Psicologia Social. In: SPINK, M. J. (Org.). Práticas discursivas e produção de sentidos no cotidiano: aproximações teóricas e metodológicas. São Paulo: Cortez, 1999.

WETHERELL, M.; POTTER, J. Mapping the Language of Racism: discourse and the legitimation of exploitation. London: Harvester Wheat Sheaf, 1992. 



\title{
Vizinhanças: de correntes a redes. Entre fofocas, jardins, compras e outras formas de vizinhar...
}

\author{
Gabriel Binkowski \\ Alan Jorge \\ Lia Braga \\ Rafael Wolski \\ Simone Frichembruder \\ Stelamaris Tinoco \\ Vera Resende
}

Num painel produzido durante uma oficina de artesanato e fuxico por moradores e cuidadores do Residencial Terapêutico Morada São Pedro ${ }^{5}$, em Porto Alegre, vemos, em uma simples figura, a complexa teia de imagens, forças, riscos, excitações,

5 Os Serviços Residenciais Morada São Pedro (SRTs MSP) são serviços da Secretaria de Saúde do Estado do Rio Grande do Sul, localizados na cidade de Porto Alegre e vinculados ao Hospital Psiquiátrico São Pedro (HPSP). Foram inaugurados em 30.12.2002, integrando o Projeto São Pedro Cidadão, ação que incluía a regularização fundiária da Vila São Pedro e a vinda de moradores egressos de internação prolongada no Hospital Psiquiátrico São Pedro. A criação desses serviços faz parte do processo da Reforma Psiquiátrica no Rio Grande do Sul e cumpre o estabelecido na Lei Federal no 10.216/2001, Lei no 10.708/2003, Lei estadual $n^{\circ}$ 11.791/2002, Portarias GM n 52 e 53/2004, Portaria no 106/MS de $11 / 02 / 2000$, Portaria $n^{\circ} 1.220 / 2000$, que os regulamentam. 
fantasias, impedimentos, palavras, enfim, tudo aquilo que vai brotando da vida de um residencial terapêutico para egressos de um monumental hospital psiquiátrico. No caso, a imagem confeccionada nos apresenta uma casa preenchida por flores de fuxico, mais precisamente, rosas multicoloridas - com forte presença do cor-derosa -, circundada por uma corrente amarela cujas pontas, abertas, se dirigem para fora. Pendurados na corrente, podemos ver uma série de bonequinhos, uns presos por durex, outros amarrados pelo pescoço com linha de costura. Ainda, notamos algumas das palavras comumente repetidas no contexto da saúde mental, dentre as quais podemos citar autonomia, respeito, cidadania, casa, tranquilidade, respeito pela vida e outras.

Múltiplos são os fluxos de leitura passíveis de serem seguidos num painel como este. A começar pela corrente: a incansável busca por cuidadores e moradores, por construir uma casa sólida, que fique em pé, protegida, que produza não apenas redes ou relações, mas correntes fortes, vigorosas, captando pessoas, vidas, afetos, serviços, olhares. Uma corrente que poderia servir também de captura, de isolamento, posto que um residencial como esse, sobre o qual falamos, aposta na singularidade possível em uma vida, mas também se faz como um conjunto de casas, de vidas, relações, forças, desejos, esses últimos, aliás, palavras tão ditas, confundidas, alteradas, até esvaziadas. Rosas, como as que preenchem a estrutura da casa, nos levam tanto ao belo, ao cheiroso, ao amor, ao casal e também a um ideal de vida "mar de rosas", de família, de isolamento, algo que nos grita uma imagem daquela família de classe média, com papaimamãe, escola e TV, como numa novela, o que podemos, muitas vezes, insistir em cravar na vida de muitas dessas pessoas egressas de um manicômio. Como nos lembra Foucault em seu seminário $O$ Poder Psiquiátrico (FOUCAULT, 2006), na aula de 28 de novembro de 1973, a família é o ponto de engate entre os diferentes sistemas disciplinares da sociedade e, portanto, funcionaria como uma cavidade dentro da qual teríamos o poder soberano operando (como a função paterna, por exemplo). Não podemos também deixar de 
lado a referência necessária de Foucault ao poder psi, função-psi, que operaria como num esforço de refamiliarizar indivíduos desviantes dessa ordem, necessária, por sua vez, a uma gestão de indivíduos que se manteriam, fariam funcionar e reproduziriam os sistemas disciplinares do resto da sociedade (indo, dessa forma, da família para a escola e, depois, para o trabalho/fábrica ou outros sistemas de reordenação, como o manicômio ou a prisão).

A busca por um ideal de casa limpa com armários organizados, habitada por pessoas que sabem "gastar direito" o seu dinheiro, sujeitos da razão, "incluídos" na cidade, permeia, muitas vezes, os projetos terapêuticos individualizados, na tentativa, às vezes obstinada, de refamiliarização dos usuários em seus Residenciais conforme aborda Foucault (1999). A percepção dessas redes de práticas "substitutivas" ao manicômio, dos mecanismos disciplinares, que atuam nos Residenciais Terapêuticos, tem nos apontado uma possível brecha para algo que chamamos de respeito à diferença, um dos principais pressupostos da Reforma Psiquiátrica.

Ao pensar nesse pressuposto, retomamos a imagem do painel; ainda nem falamos dos próprios bonecos juntos à corrente, ora rede de afetos, ora de serviços que confluam a vida para lá fora, para uma cidade, aquele ideal "Vamos invadir a cidade!" que muitas vezes esquece que alguém pode querer não invadir sua cidade, e sim ficar próximo de seu portão, sentado com uma cuia de chimarrão em mãos, delirando, de fato, sobre o próximo jogo de futebol da dupla Gre-Nal (como na cena entre Jorginho e Cleusa narrada logo abaixo). E nem precisamos citar o risco de "enforcarmos" pessoas numa corrente como essa, como os bonequinhos do painel, com o constante risco do sufocamento e da disciplina, seja a do manicômio, seja a da complicada vida das cidades, com seus imperativos, demandas, produtos. E estar exposto a tais riscos e sufocamentos só se dá para aqueles que habitam uma cidade de um outro jeito, na amplitude de seus trânsitos, e não apenas como morador daquele pedaço da cidade que chamamos de hospital psiquiátrico. 
Habitar a cidade de outros modos, como Belo, morador do Residencial Terapêutico Morada Viamão6, caminhando no centro da cidade, sendo cumprimentado por onde passa. Entra nos estabelecimentos comerciais, pega panfletos de propagandas, ofertas, cartões de visita e redistribui nas ruas aleatoriamente. Às vezes, vai ao centro, inclusive de madrugada, toma um café na funerária e circula em outros poucos pontos abertos. $\mathrm{O}$ plantonista da funerária diz que gosta de recebê-lo, pois "batendo papo, a noite passa mais rápido”. Em seu percurso diário, conversa com algumas pessoas, entra em conflito com outras, mas, de maneira geral, é bem quisto. Uma prova disso é a comunidade no Orkut em sua homenagem, a qual conta com mais de 2.900 integrantes.

Belo experimenta devires no encontro com a rua, com a liberdade, com o caos urbano, que somente um corpo ainda por vir pode experimentar. Corpo que parece viver com toda intensidade possível os encontros que o território da cidade propicia, ultrapassando o possível no encontro entre corpos, produzindo agenciamentosloucos com o corpo-mulher, corpo-criança, corpo-café-oferecido, corpo-som-ofertando, corpo-motorista, corpo-cobrador, corpopanfleto, corpo-diferente, corpo-diferença. Figura física que parece carregar em si toda a fragilidade de um corpo moribundo, de corpo por muitos anos institucionalizado, corpo egresso de manicômio, contudo carrega a potência que só um corpo que fora aprisionado carrega em si.

Entre encontros e desencontros, novas formas de habitar a cidade foram se construindo. Assim como os residenciais, desenhados em riscos traçados por seus moradores, seus cuidadores, verbas, tentativas de captura e, acima de tudo, suas vizinhanças. Mas, os

6 Os Serviços Residenciais Morada Viamão são serviços da Secretaria de Saúde do Estado do Rio Grande do Sul, localizados na cidade de Viamão, região metropolitana de Porto Alegre. Foram reinaugurados em setembro de 2005, onde no local existia o Residencial Morada Dom Bosco. 
residenciais, se possível e permitido, foram tentando deixar tais configurações de residenciais, permanecendo apenas como um tênue desenho que vai ligando pessoas em suas casas, no meio de cidades, com seus prazeres, perigos, feiuras, belezas, belezas misturadas com feiuras, preços baratos e salgados, preços de salgadinhos, drogas, prostitutas, jogos de futebol, pedras arremessadas contra janelas, shoppings. Tudo que envolve a vida das cidades.

Segundo Certeau (1994), “[...] a cidade se vê entregue a movimentos contraditórios que se compensam e se combinam fora do poder panóptico."

A cidade nos traz então diferentes possibilidades, contradições, permitindo escapar das amarras do olhar panóptico, que tudo vê e controla, tornando-se "[...] o tema dominante dos legendários políticos, mas não é mais um campo de operações programadas e controladas" (CERTEAU, 1994).

Mas que cidade é esta que oferecemos aos diferentes? Que promessas ela nos traz?

Para pensarmos nessa questão, abordaremos os residenciais e seus "vizinhos", situando-os no espaço da cidade.

O Residencial Terapêutico Morada São Pedro nasceu num terreno vizinho ao hospital psiquiátrico do qual saíram seus moradores. Além disso, faz borda, e também se mistura com uma vila do município cotidianamente chamada de Vila Cachorro Sentado.

Temos, portanto, para dar sequência a este quase conto ao qual nos propomos, inúmeras possíveis relações de vizinhança. Podemos olhar para o residencial em separado da Vila, ligando-o ao Hospital Psiquiátrico São Pedro, podemos falar de todas as relações de vizinhança que se dão entre os moradores do residencial, entre o residencial e a vila. De forma até mais intensa, é possível apagar a diferença entre o residencial e a vila, comentando sobre a vizinhança 
com o hospital ou ainda todas as conflituosas relações de uma das vilas do município de Porto Alegre.

Isso posto, apresentaremos esses residenciais não apenas como serviços substitutivos, ou, como querem alguns, uma unidade de um hospital psiquiátrico, ou, como pode olhar alguém de fora, as casinhas mais "arrumadinhas" da Vila Cachorro Sentado. Escrevemos sobre as vizinhanças. E o que fica aberto com isso.

Escrever sobre as vizinhanças abre, entre outras possibilidades, um espaço para refletirmos sobre a arquitetura e o urbanismo para além de sua funcionalidade. Como nos diz Baudrillard em $O$ Sistema Dos Objetos (BAUDRILLARD, 2000), que estruturas mentais se misturam a essas estruturas funcionais e as contradizem, sobre que sistema cultural, infra ou transcultural funda-se a sua cotidianidade vivida.

Loucura e pobreza desfilam lado a lado para o estranhamento de nossos olhares etnocêntricos e ainda turvos de uma ótica manicomial. Uma vizinhança possível, com códigos, barganhas, errâncias que deixam nossas matizes mais higienistas incomodadas.

Sob olhares surpresos de habituais consumidores de um shopping vizinho da vila, adentram os loucos no lugar dos "ricos" com sua singularidade debaixo do braço e com poder aquisitivo para consumir. Tal curioso fato se dá pelo direito adquirido desses expacientes de manicômio a serem detentores de benefícios e bolsas de auxílio.

Mas voltamos aos "loucos com poder de compra" e sua relação com os "pobres da vila”. E não precisamos levar estes conceitos até as mais distantes abstrações para enxergarmos sua pregnância na vida de um residencial. No caso a seguir, ocorrido com muito pouco tempo de vida compartilhada entre o Morada São Pedro e a vila, vivíamos numa época de medos mútuos. Enquanto os moradores do residencial temiam seus vizinhos, os riscos de roubos, as chacotas, os moradores da vila olhavam sempre de sobreaviso para seus novos 
vizinhos: teriam eles a capacidade de desligar um fogão, de cuidar de sua casa evitando possíveis problemas e até mesmo uma tragédia?

Nessa relação entre "loucos" e "pobres", estas produções se encontram e se entendem. Às vezes, atrapalhados por atitudes intervencionistas de quem exerce cuidado e tropeça na tutela policialesca, como na cena a seguir:

Num desses dias iniciais de Residencial, Iara mantinha sua casa extremamente chaveada, não apenas por receio, mas também por preconceito e por manter-se sempre reservada - hábito que, diga-se de passagem, mantém até os dias de hoje. No entanto, quando um excesso de fumaça é visto saindo de sua casa, todos na vila já o sabiam: "onde há fumaça, há fogo"! O caminhão de bombeiros já chegara, fazendo todo o estardalhaço possível, vizinhos se aglutinavam de fronte à casa da moradora quando um bombeiro bate apressadamente na porta. Iara, irritada e com pressa, abre e para a surpresa do bombeiro, vai logo respondendo: "mas eu estou fritando um bife. Tu não tens mais o que fazer da vida? Vai trabalhar!”, e termina batendo com a porta na cara do bombeiro, cujo estarrecimento também se fazia presente na cara de todos os vizinhos que se espreitavam para assistir ao possível incêndio.

Resquício de imersões manicomiais que conformam a todos, esses vizinhos ficam mais distanciados. Distância imposta por quem media a conversa e olha a partir de seu locus moral, lente única para ler o mundo, que insiste em determinar destinos e homogeneizar comportamentos, como o que observamos no olhar dos vizinhos ao Residencial onde mora Iara.

Quando os moradores do residencial entram na rede de trocas da vila, temos o risco de que trabalhadores não vejam aí nada mais que exploração, usurpação e perigo. Perde-se o olhar sobre os significados das relações e a constituição de pertencimento ao território onde a troca tem a ver com certa identificação - à existência num espaço psicogeográfico. 
Neste câmbio e ajuste cultural em que essas pessoas estão envolvidas, estabelecer práticas de vizinhança, códigos que organizem a convivência, faz-se por meio de muitas trocas, internas e externas. Troca-se açúcar, erva-mate, serviços, olhares, cuidados, vigilância, tiros, drogas, objetos, favores, lugares e saberes. Troca-se a vida de lugar dentro de si cotidianamente para dar conta do imprevisto. Trocam-se preconceitos.

Ana trabalha com a venda de cosméticos de porta-a-porta, trazidos pelo "baiano", comerciante da cidade. Também vendia pastéis aos taxistas do shopping, porém, ao percorrer a vila e chegar ao local, muitas crianças, instigadas pelos concorrentes, pediam dinheiro e mexiam com ela e sua companheira. Refere que "as pessoas têm muitos preconceitos com quem morou no São Pedro", por isso sempre omite essa informação. Ao mesmo tempo no lugar onde mora, mantém uma relação de distanciamento com os demais moradores, referindo-se a eles como pessoas pobres, culturalmente inferiores, loucos.

Por esse motivo, afirma que não vê a hora de morar em outro lugar, assim como o prédio da PUC (Pontifícia Universidade Católica) onde estudou e "está localizado em um local arejado, lindo, onde circulam pessoas educadas que a deixam calma, tranquila”.

Desde a Nau dos Loucos ao olhar higienista e excludente da medicina sobre a loucura, esta tem se situado no campo dos indesejáveis. Estes mesmos que no contexto que descrevemos se instalam, se misturam esgueirando-se do olhar da saúde pública, quase epidêmico para a absorção de singularidades; uma alteridade por demais estranha, mas que se coloca no urbano.

Trabalhadores e moradores tecem novas relações, experimentam possibilidades diferentes de diálogo com o espaço urbano e com seus espaços subjetivos, trânsitos múltiplos entre o dentro e o fora dos muros, dos muros de concreto e dos muros subjetivos, subjetividades resistentes à erosão do que está instituído. Trabalhadores que 
se encontram também em processo de acomodação/incomodação, acomodam o novo e se incomodam com o estranhamento, com o que se mostra tão diferente. Sobrevivem todos e inventam formas de organização dentro destes territórios, cavando pertencimentos, laços, novas miradas sobre a vida, enfim, participando algumas vezes nesta cena de vizinhança, sendo parte do "vizinhar".

No Residencial Morada Viamão, por exemplo, vive-se um momento diferenciado com alguns moradores que buscam outros locais de moradia, inaugurando novas formas de morar na cidade em diferentes pontos. Tal cenário requer dos trabalhadores a aprendizagem de novos modos de atenção. A necessidade de apoio e cuidado a alguns usuários da saúde mental levou à criação de outras práticas e olhares de atenção em saúde. Assim, os trabalhadores tiverem de desenvolver uma circulação para realizar tais acompanhamentos, para auxiliar na constituição de novas redes.

Edson, um ex-morador desse residencial, é uma das pessoas que inauguram esta nova tendência: a busca de uma nova vizinhança. Optou pela escolha de outro espaço onde reside sozinho, não mais dividindo com outras cinco pessoas como quando vivia no residencial. Vindo do Dom Bosco, onde vivia em uma unidade com mais de 100 pessoas, onde comia na mesma hora, em pratos de plástico e colher, onde suas escolhas eram limitadas, optou por seguir adiante ainda, queria um espaço só dele.

O espaço escolhido: uma peça em um cortiço na Vila Gaúcha, conhecida na cidade pelo tráfico e pela violência. Nas primeiras semanas de Edson em sua nova morada, sua TV é roubada, gerando muita angústia nele e na equipe do Morada Viamão. A primeira hipótese levantada na reunião de equipe foi de Edson retornar ao residencial onde mais pessoas o acompanham, um lugar supostamente mais seguro. Contudo, essa hipótese foi descartada pelo próprio Edson e o mesmo trouxe outra alternativa. Conforme sugestão de uma vizinha, colocar a TV dentro de um suporte gradeado, tal qual esta vizinha tinha em sua casa, era uma forma de prevenir 
o roubo. A dificuldade de pensar outras alternativas para além da tutela e do controle é um desafio que precisa ser exercitado e discutido cotidianamente e como tarefa infindável.

Mas, ao pensarmos na cidade, temos de supor que a arquitetura também ocupa sua função de vizinhança e da configuração do próprio 'vizinhar'.

Ao tratamento da loucura no século XIX, corresponde uma estética e uma iconografia que ainda subsistem nas construções posteriores: a divisão por pavilhões, os espaços internos (átrios) destinados ao "tomar sol", os refeitórios coletivos, os espaços amplos. Os prédios construídos posteriormente conservam a proposta que ensejou a construção do manicômio: a existência de um espaço tranquilo e ordenado, especialmente projetado para abrigar a loucura, retirado da agitação da cidade, provido de vastas sombras e conforme uma expressão da época, construído segundo as "regras da boa arte". Importante esse cuidado ao pensarmos que os ornamentos já foram considerados capazes de produzir uma sensação de plenitude e de repouso ao olhar e à mente. $\mathrm{O}$ manicômio ornamentado revela as boas intenções dos alienistas.

$\mathrm{Na}$ vila Cachorro Sentado, tudo é incerto e fragmentado, como os abrigos que a compõem. O trabalho com fragmentos, presente na experiência diária da maioria dos moradores, estende-se na construção e manutenção de abrigos/casas, que são estruturas sempre em incompletude. A efemeridade dos materiais determina os ciclos de construção, reforma e demolição das casas e a ocupação dos espaços. Nestes, é tênue o limite entre o interior e o exterior. Há uma forte e constante intervenção sobre o espaço público: ultrapassagem de fronteiras, ocupação desenfreada. O morador constrói o abrigo da sua subjetividade.

Entre formas antagônicas (agônicas) de ocupar o espaço, encontramos o Residencial Terapêutico Morada São Pedro, um conjunto de casas construídas conforme modelos arquitetônicos cartesianos, 
estética que corresponde a expectativas de normalização oriundas de um poder externo que pretendeu incidir sobre toda a vila, mas que somente alcançou algum êxito no que concerne às casas do Residencial. Somente os loucos mantêm a estética do projeto inicial, suas casas não sofreram alterações: permanecem amarelas, de um único andar, protegidas por grades padronizadas.

Todavia, tais faltas de alteração não são tão plenas: as mudanças foram se dando meio nas bordas, nos cantinhos. Após receberem suas casas, com um mobiliário de utilidades e de qualidade para as tarefas do cotidiano, as trocas, escambos e comércios foram acontecendo. Se pensarmos a subjetividade como resistência (PALOMBINI, 2007), encontramos o intenso poder de uma vizinhança como a da vila Cachorro Sentado e do comércio da região: jamais deixaram de se dar as trocas de móveis, as compras de usados, compras à prestação no shopping center vizinho ao residencial e, por sua vez, até mesmo os roubos atestam como as trocas jamais cessam de se fazer presentes numa cidade, posto que uma cidade tem por condição para seus moradores os perigos que nela habitam.

O traçado da cidade moderna, presente no projeto arquitetônico do residencial Morada São Pedro assim como em qualquer outro bairro, condomínio, casa residencial ou comercial, principalmente quando com construções destinadas ao uso de extratos populares, tende para a rigidez e ordenação, para o racional e ideal. A presença humana, porém, com suas experiências e relações, transforma os espaços, colorindo de vida e de inesperado as janelas, que antes de receberem cortinas já foram todas iguais, os jardins, que antes de crescerem as roseiras e os maracujazeiros já foram todos iguais. Até mesmo as ruas, onde agora se esparramam moitas de "pingo d'ouro" (plantadas para impedir que os carroceiros construíssem estábulos onde deveria haver uma calçada) se modificaram à força das relações. Foram essas mesmas relações, nem sempre tranquilas, que resultaram na substituição de carcaças de automóveis e outros entulhos por balanços, gangorras e traves para marcar alguns gols, 
ou seja, uma praça. Um espaço de lazer profundamente respeitado, construído em uma das bordas de um espaço de segregação socioeconômica. De forma análoga, os roubos e outras formas de violência também se passavam no hospital psiquiátrico.

Passados alguns anos, os moradores encontram cada vez mais necessidades de compras, mais utilidades e, especialmente, luxos já presentes em todas as classes sociais, como é visto em inúmeras casas, de máquinas de pão passando por aparelhos de DVDs às tão fundamentais (e subjetivamente fundantes) camisas de futebol.

Em algumas residências, a rejeição à estética desviante, interpretada apenas como parte da miséria presente na vila, gera um fenômeno de idealização do interior das casas conforme modelos tradicionais burgueses oriundos do século XIX. Manter a casa impecável sinaliza que seu morador esteve muito tempo no hospital psiquiátrico, mas que ainda é de outra estirpe. Não é um "maloqueiro". O típico interior burguês, composto por móveis (com função mais simbólica do que prática), acumulação e confinamento, é interpretado como atestado de reabilitação psicossocial. Cozinha, sala de estar, dormitórios e banheiro correspondem a diversas funções e remetem a uma concepção de indivíduo como sendo uma reunião equilibrada de faculdades distintas.

Baudrillard (2000) nos fala da casa, da residência, como uma unidade conformada antes por critérios simbólicos do que espaciais. Neste sentido, a casa se faz terapêutica quando proporciona ao sujeito mutilado pela conformação dos ambientes institucionais a possibilidade de buscar suas próprias conformações simbólicas. Semelhantes em muitos aspectos às casas das nossas infâncias, estruturas complexas de interioridade onde os objetos descortinam diante de nossos olhos são uma configuração simbólica chamada residência.

A descontinuidade do projeto de urbanização da vila Cachorro Sentado, retomando o assunto, deu-se tanto no que competiu à vontade política das gestões do estado do Rio Grande do Sul, quanto 
à própria disponibilidade dos moradores que foram contemplados no primeiro lote de construções. Estes optaram por não manter a homogeneidade estética da proposta ao colorirem de "puxadinhos" e montes de entulho o espaço circundante às suas casas.

Ao transformar os becos em ruas arejadas, onde se alinham casas idênticas, percebe-se a valorização da permanência e da rigidez, atributos que, somados aos ornamentos anteriormente citados, acabam por caracterizar as "normas da boa arte" presentes na concepção do manicômio. No Residencial, todavia, essa mesma tendência normalizadora poderia chamar-se, em uma acepção mais aproximada das questões do design nascido no modernismo, "normas da boa forma". De maneira homóloga, o hospício pretendeu criar um ambiente terapêutico ideal, capaz de, por meio de sua organização, solidez e ornamentação, apaziguar a fúria dos loucos.

As formas de organizações arquitetônicas do Residencial Morada São Pedro pretendem interferir sobre estabilidades, que nós chamamos de relativas, mas que são vistas pelo senso comum como inexistentes ou frágeis, de uma forma tão profunda que as reconstituiria identitariamente.

Por fora, as casas são idênticas, mas seus interiores guardam histórias de vida, de morte, de passados ricos e saborosos para a imaginação. Histórias para além da institucionalização. $\mathrm{O}$ manicômio correspondeu à necessidade social de ocultar o diferente; o residencial terapêutico, por sua vez, ao proporcionar a circulação do diferente, o cotidiano do "vizinhar", cria, por meio da partilha de espaços públicos e de áreas comuns, relações tão ricas que rompem com o poder das definições identitárias. Dona Socorro, desautorizada deste vizinhar por décadas na internação psiquiátrica, dá conselhos à vizinha da casa em frente sobre como aquecer a moradia no inverno. Dona Dalva, indisfarçavelmente delirante, é atendida no mercadinho com a saudável e usual indiferença que caracteriza a maioria dos comerciantes. A naturalidade dessas relações é a via de acesso para que inúmeros relatos - breves como o de Dona Dalva 
sobre os meninos que comiam cachorros ou longos e romanceados como as aventuras de Dona Anitinha como prostituta no Paraná circulem no campo social.

A cidade faz-se assim um espaço fértil de trocas. Trocam-se hostilidades, estranhezas. Contudo também se trocam afetos que não passam somente pela via da violência e da tragédia, como querem nos convencer os discursos higienistas. Como podemos presenciar novamente com Edson semanas após o roubo de sua TV. Quando vagou outra peça no mesmo cortiço, esta fora indicada para outro morador que viria do hospital psiquiátrico São Pedro como possibilidade de moradia. No dia em que foram limpar a peça para mudança, um grupo de pessoas do cortiço auxiliava, criando um espaço de acolhimento e possibilidade de novas redes de relações. Além de Edson, do morador que estava prestes a sair do hospital e de um trabalhador da equipe do residencial, também, estava envolvida nesta arrumação uma menina vizinha de Edson. Entre conversas descontraídas, na falta de materiais como vassoura e pá de lixo, a menina prontificou-se a pedir para sua mãe estes instrumentos, o que possibilitou a continuidade da limpeza e da mudança.

Derrida (2003), em sua conferência Da Hospitalidade, coloca em questão a noção de estrangeiro, tão cara e necessária aos dias de hoje. Quando os movimentos de desterritorialização e intenso fluxo de capital se unem a movimentos migratórios infindáveis e violentos, não cessam os cambiamentos incessantes das formas de viver, dobradas e transformadas numa velocidade incrível. Vemos aí o aparecimento de riscos, hostilidades e bolsões de diferença. $\mathrm{O}$ estrangeiro se coloca como aquilo que é encarado como de outra ordem e, por sua vez, evocaria a questão da hospitalidade daquele que recebe, ou não, daquele que induz sempre a uma certa relação de violência, a primeira violência, comenta o filósofo francês, aquela de pedir ao estrangeiro que compreenda, que fale nossa língua.

Por língua, podemos experimentar como Deleuze e Parnet (1998) nos propõem um tal de uso minoritário da língua, qual seja, 
essa gagueira de linguagem, esse mau uso que um estrangeiro faz da língua e, voltando a Derrida, deparamo-nos com o fato de o estrangeiro ter um certo contrato de hospitalidade, uma necessidade de compreensão de uma língua para, a partir disso, responder a determinadas configurações jurídicas de uma sociedade. A partir daí, ele seria um sujeito, sujeito de direito.

Todavia, num residencial, quem é estrangeiro? De forma simplificada - e a simplificação costuma ser a mãe de homogeneizações, de absolutismo, totalitarismo, vide o hospital psiquiátrico -, podemos pensar naquela ideia romântica de loucos habitando uma cidade, carregando um não-dito, a verdade, o manifesto da verdade em sua voz, alethéia. Ainda, vemos a comparação de residenciais com estas caravanas nômades que vêm, habitam, vivem, vão, deixam pedaços, coisas. Não precisamos chegar por estas linhas. No caso do residencial ao qual nos referimos, o estrangeirismo se dá por muitas partes - e o risco de violências e capturas também, melhor, o risco de correntes e enforcamentos.

Capturas e sufocamentos tão intensos que envolvem e encadeiam até mesmo o discurso dos próprios moradores dos residenciais. Numa noite de quarta-feira de decisão de futebol, Cleusa, moradora do Morada São Pedro, ouvia os gritos de um de seus vizinhos, Jorginho, com quem mantém uma velha rixa pessoal - aliás, em que vizinhança ela não existe? Com o histórico de uma vida de passagem por instituições, Cleusa acabou aprendendo a fazer uso de médicos, técnicos ou mesmo de guardar para chegar até seus objetivos. Nessa noite de quarta-feira, Jorginho gritava por horas a fio, na expectativa de que o Sport Club Internacional, seu clube do coração, marcasse um gol nos derradeiros minutos de um jogo pelas quartas-de-final da Copa do Brasil. Gol este aguardado por quase metade do estado, da cidade, e cuja espera fazia Jorginho gritar em mortal desespero a cada lance sem êxito de seu time. Quase no fim da partida, alguns guardas são chamados até a residência de Jorginho e, acompanhados por Cleusa, averiguam o que estaria se passando: "Ele está em surto", 
afirmava a moradora e 'rival' de Jorginho. Este, por sua vez, apenas pode gritar: "Eu tô esperando o gol!".

Jorginho, de tão inserido nos fluxos de existência de seu território existencial, uma cidade-estado-país com fanáticos torcedores de futebol, teve o risco de ser considerado "em surto", justamente por alguém que, como ele, já vivera este estrangeiro que é o estar em surto, estar no fora e ser posto no locus onde o fora deveria ficar: o lugar do perigoso e sem lógica, levado pela polícia.

Essas relações e vida que viemos até aqui traçando, esboçando, acontecem onde a vida tem potência de invenção, de criação de novos territórios existenciais. Exige troca, partilhamento, parceria "[...] por um cuidado com a vida, intersecção entre saúde, educação e movimento social [...]" (FAGUNDES, 2009), germinando sempre em nosso convívio.

Portanto, deparamo-nos com um conjunto de desafios como estar em processo de invenção permanente de si mesmo, usuários e serviços. Assim como a intervenção em dois campos indissociáveis, práticas de saúde e as práticas de gestão que são construídas cotidianamente num residencial terapêutico segundo alguns princípios de trabalho que articulam um certo modo de fazer, de construir roteiros a partir de caminhos encontrados. Não é suficiente, pois, neste território, necessitamos de arranjos permanentes de processos de trabalho.

E, para quem, como os trabalhadores, está em ato frente à intensidade destas produções, a vida não é fácil nestas paragens. Cotidianamente, inventam-se e reinventam-se modos de lidar com a diversidade, com alteridades tão díspares. A necessidade de remexer possibilidades subjetivas de conviver se atualiza constantemente exigindo reflexão, partilha e o alargamento de nosso olhar. A ebulição destes vizinhares e múltiplas caminhadas forja novas formas de existência/resistência que deem conta de acomodar a enorme sensação de estar sempre no olho do furacão, de sentir-se a descoberto. 
Acreditar nesses projetos, como os de nossos residenciais, significa construir o sonho e arriscar-se a inúmeros arranhões, deixar-se sacudir pela vida e ver o que acontece.

Para nos despedirmos destas vizinhanças, faz-se necessário marcar a imprevisibilidade e o movimento incessante das trocas, relações e mutações que configuram o tecido social. Em meio a capturas, há resistências, produção ininterrupta de subjetividade, algo que devemos salientar quando o exercício de desinstitucionalização da Reforma Psiquiátrica se vê ocorrendo na sociedade, especialmente com aqueles ex-pacientes que já circulam por aí, não ficam mais restritos a olhares de controle manicomiais. A vida não deixa de ser sempre outra, trocar, cambiar, expor-se até a outras formas de controle. Como ensaiamos em todo esse escrito, vizinhar.

\section{Referências}

BAUDRILLARD, J. O Sistema dos Objetos. $4^{\text {a }}$ ed. São Paulo: Perspectiva, 2000.

CERTEAU, M. A Invenção do Cotidiano: artes de fazer. Petrópolis: Vozes, 1994.

DELEUZE, G.; PARNET, C. Diálogos. São Paulo: Escuta, 1998.

DERRIDA, J. Anne Dufourmantelle Convida Jacques Derrida a Falar da Hospitalidade. São Paulo: Escuta, 2003.

FAGUNDES, S. Aula Proferida na Residência Integrada e Curso de Especialização em Saúde Mental Coletiva. Porto Alegre, 2009. (Comunicação oral). 
FOUCAUlT, M. O Poder Psiquiátrico: curso dado no Collège de France (1973-4). São Paulo: Martins Fontes, 2006.

Em Defesa da Sociedade: curso no Collège de France (1975-6). São Paulo: Martins Fontes, 1999.

PALOMBINI AL. Vertigens de uma Psicanálise a Céu Aberto: a cidade, contribuições do acompanhamento terapêutico à clínica na reforma psiquiátrica. 2007. 247f. Tese (Doutorado em Medicina Social). Rio de Janeiro: Universidade Estadual do Rio de Janeiro: Instituto de Medicina Social, 2007. Disponível em: <http://bases.bireme.br/cgibin/wxislind.exe/ iah/online/?IsisScript=iah/iah.xis\&src=google\&base=LILACS\&lang=p\&n extAction=lnk\&exprSearch=449190\&indexSearch=ID >. Acessado em: 26 de jun 2009. 


\section{Com a palavra, os profissionais: estudo das representações sociais da autonomia dos moradores da "Casa Azul".}

Jaqueline Queiroz de Macedo

Maria de Fátima de Araújo Silveira

Maria do Carmo Eulálio

\section{Introdução}

A Constituição Federal de 1988 origina o Sistema Único de Saúde (SUS), regulamentado dois anos depois pelas Leis $\mathrm{n}^{\circ}$. 8.080/90 e 8.142/90, dedicando uma seção do capítulo II para tratar exclusivamente da saúde, o qual fundamenta os princípios e diretrizes norteadores dos serviços de saúde, quais sejam a universalidade e hierarquização ao acesso dos serviços, equidade e integralidade da atenção, com o objetivo de modificar a situação de desigualdade assistencial à saúde da população, pautado na descentralização e na municipalização da atenção (BRASIL, 2003).

Em uma breve retrospectiva da situação político-administrativa do Brasil para poder se entender o contexto no qual ocorreram essas modificações, nas décadas de 1970 e 1980 surgiram vários movimentos sociais bastante relacionados à luta pela transição democrática da pós-ditadura. Tal processo, dentre outros avanços, ocasionou a 
redemocratização do país com ampliação das liberdades individuais e introdução dos direitos de cidadania que, anteriormente, não existiam no sistema jurídico brasileiro (GUIMARÃES, et. al., 2001).

Desse modo, adentra-se a década de 1980 com uma sociedade efervescente, após 21 anos de dominação pelas elites ditatoriais, buscando construir uma sociedade justa e cidadã, vindo á tona inúmeras denúncias acerca da psiquiatria, na questão da saúde.

Tal como o SUS, a Reforma Psiquiátrica brasileira apresentou-se como um processo de intensos movimentos político-sociais que modificaram tanto os significados de saúde, como as práticas em saúde mental (ANTUNES, QUEIROZ, 2007).

A Reforma Psiquiátrica no Brasil aparece, de modo mais ativo, no final da década de 70, no contexto da redemocratização, inspirado pelo processo de desinstitucionalização que ocorreu na Itália, através de Franco Basaglia. Nesse período, surge o Movimento de Trabalhadores de Saúde Mental (MTSM) à procura do significado da função social da psiquiatria e o que lhe envolve, ampliando o foco para além do seu papel médico-terapêutico, e assim visualiza a mudança desse modelo a partir do significado de desinstitucionalização. Na busca de transformações na saúde mental, o MTSM envolve familiares, usuários e a sociedade na discussão relacionada à assistência psiquiátrica e, em 1987, realiza a I Conferência Nacional de Saúde Mental, com o lema "Por uma Sociedade sem manicômios" (AMARANTE, 1995; TENÓRIO, 2002).

Nesse contexto, em 1989, o Deputado Federal Paulo Delgado apresenta o Projeto de Lei 3.657/89, baseado na experiência italiana, que propunha a extinção progressiva dos leitos psiquiátricos clássicos, substituindo-os por outras alternativas de assistência e tecnologia de cuidados, o qual, juntamente com a Luta Manicomial, culmina na Reforma Psiquiátrica. Contudo, apenas 11 anos depois, é aprovado com a Lei $\mathrm{n}^{\circ} 10.216$, redirecionando o tratamento psiquiátrico para os programas substitutivos e normatizando a internação compulsória (GUIMARÃES, et. al., 2001). 
O modelo do processo brasileiro de reforma psiquiátrica está fundamentado na desinstitucionalização, processo, não meramente restrito ao campo técnico, administrativo, jurídico, legislativo ou político, mas, e principalmente, ético, de admissão e compreensão de nova práxis, responsável pela apresentação de "novos sujeitos de direito e novos direitos para os sujeitos" (AMARANTE, 1995).

A partir desse significado, pode-se inferir o objetivo fundamental dos serviços substitutivos que vieram a se constituir como alternativa para a hospitalização de sujeitos sofredores psíquicos, marginalizados e isolados historicamente da sociedade, como sujeitos destituídos de razão, e envoltos por um misticismo de medo e exclusão (FOUCAULT, 2005).

Trata-se de uma nova construção de conceitos, de locais alternativos de sociabilidade e possibilidades reais, de inclusão, de cidadania urgente através da presença ativa no trabalho, na família, na vida social, entre amigos, por terem, por tanto tempo, sido retirados os direitos desses personagens em desvantagem social (GUIMARÃES, et. al., 2001).

Desse modo, os serviços substitutivos devem estar fundamentados em uma cidadania e ética diferentes, que ultrapassem o pensamento liberal da cidadania social e ética política, restritas aos direitos e deveres e aliadas à emancipação individual e foquem os variados modos de exclusão social atual (GUIMARÃES, et. al., 2001).

O município de Campina Grande-PB possui uma experiência exitosa no âmbito da Reforma Psiquiátrica, uma vez que conseguiu realizar a desinstitucionalização e reorientação da rede de serviços em saúde mental (BRASIL, 2007). Esse processo teve início em 2005, com o descredenciamento da rede SUS, do Hospital João Ribeiro, responsável, na época, pela internação de grande quantitativo dos usuários psiquiátricos da região, devido à identificação de uma calamitosa situação administrativa, assistencial, financeira e institucional daquele manicômio. 
Com base em um processo de desinstitucionalização e não de desospitalização, os 176 usuários internos foram acompanhados, reencaminhados as suas famílias ou serviços de saúde de suas localidades de origem, havia internos residentes no hospital com longa permanência atingindo até 30 anos de internação (BRASIL, 2007). Tais sofredores psíquicos, algumas vezes, já haviam perdido o elo de ligação familiar e laços sociais e se tornado verdadeiros moradores do hospital psiquiátrico, sendo, nesses casos, encaminhados para as residências terapêuticas.

O Serviço Residencial Terapêutico (SRT) compõe a rede de serviços substitutivos à instituição asilar, previsto na Reforma Psiquiátrica. Encontra-se regulamentado pela Portaria ${ }^{\circ} 106 / 2000$ do Ministério da Saúde, a qual o define como casas inseridas na comunidade, destinadas a egressos de longas internações psiquiátricas que não tenham suporte familiar e social que lhes possibilite a inserção social (BRASIL, 2000).

Tal como a reforma não é um movimento estanque, as residências terapêuticas também não o são. Assim, a depender da condição do usuário e da sua adaptação, ele pode ir morar em outra casa, ou ser criada uma moradia específica para aqueles que apresentam determinada característica, como ocorreu com a 'Casa Azul'. Essa residência foi criada através da observação e do remanejamento dos usuários que faziam parte das outras seis moradias, cujos moradores, segundo discursos dos profissionais do CAPS, desenvolveram uma singularidade, a autonomia (MACEDO, SILVEIRA, 2008).

Inúmeros são os ex-internos desinstitucionalizados em cujos prontuários existiam anotações de que eram alheados, não apresentavam interesse social, com ausência de iniciativa, que foram participantes ativos de uma transformação fundamental. O necessário para que isso ocorra é dá-lhes a oportunidade de participar da desinstitucionalização (AMARANTE, 2007). 
O projeto de desconstrução do hospital psiquiátrico possibilitou a implantação de uma rede de cuidados substitutiva, cuja discussão foi norteada por três princípios, a saber: do confinamento à liberdade; da tutela à autonomia e do trabalho protegido à produção da vida. Princípios esses que nortearam a desinstituição do asilo manicomial, em 2005, na cidade de Campina Grande (CAMPOS, 2005).

Mas, como tratar de Autonomia quando se pensa sobre sujeitos 'sem razão', destituídos de cidadania em sua totalidade, ainda rodeados de (pré)conceitos?

Através do modelo de Reabilitação Psicossocial proposto pela Reforma Psiquiátrica, fornece-se crédito aos sofredores psíquicos, o que lhes possibilita o próprio desenvolvimento.

Devido à importância desse conceito na Reforma Psiquiátrica, questiona-se qual o caráter da autonomia desses moradores? Qual a representação dos profissionais a esse respeito? Qual a dinâmica da casa, bem como, a quem compete a sua administração? Como os moradores estão participando da vida social? Afinal, como os profissionais veem os moradores ex-institucionalizados administrando sua Autonomia? Como eles representam a Autonomia dos moradores da 'Casa Azul'?

O referencial teórico-metodológico utilizado nesta pesquisa baseia-se na perspectiva teórica da Representação Social. A opção por esta vertente deveu-se principalmente à sua capacidade de relacionar o social e o psicológico como ação dinâmica. Essa teoria é bastante utilizada em trabalhos que buscam analisar a compreensão do senso comum sobre a doença mental (JODELET, 1998).

Em sua teoria, Moscovici caracteriza os processos formadores da estrutura das representações em: objetivação, materialização do objeto abstrato; e ancoragem, interpretação do objeto. Assim, as Representações Sociais atuam interpretando a realidade, como um sistema que orienta as relações dos indivíduos com o meio, determinando suas atitudes e prática, sendo um roteiro para as ações e relações na sociedade (SOUZA, 1999). 


\section{Compreensão dos significados dos discursos}

Os profissionais constroem as representações sociais da autonomia dos moradores da 'Casa Azul' em torno dos seguintes núcleos de significado: Capacidade de transitar sozinho; Presença de responsabilidade; Relação com a família; Administração do dinheiro; e Significado da 'Casa Azul'.

Capacidade de transitar sozinho: A Reforma Psiquiátrica apresenta como pressuposto fundamental a reinserção social do sofredor psíquico, através do seu retorno à comunidade, prioriza a atenção de base comunitária nos Centros de Atenção Psicossocial, nos Programas de Saúde da Família com grupos de Saúde Mental, nos Serviços de Residência Terapêutica, nas Emergências psiquiátricas para que os indivíduos não sejam excluídos e internados em asilos psiquiátricos.

A possibilidade de estarem morando na cidade em si, já é uma alternativa terapêutica para aqueles sujeitos provenientes de longas internações psiquiátricas como é o caso dos moradores da 'Casa Azul'.

Quando da criação dessa Residência Terapêutica, um dos critérios utilizados para escolha dos moradores foi, exatamente, a possibilidade de transitar sozinho pela comunidade sem a necessidade de alguém lhe trazer de volta, o que significa a não necessidade dos profissionais vigiarem exaustivamente esses sujeitos.

Sendo visível a importância da possibilidade de fazer as atividades por si só, é relevante a conquista do 'ir e vir', no plano material, como se verifica a seguir:

(...) (Os moradores da Casa Azul) podem muito bem pegar um ônibus só, ir ao comércio só, fazer compras só, vir para o CAPS só. (P1) 
(..) eles sabem que eles podem abrir a porta, $e$ sair mesmo numa boa. (P2)

(...) eles já caminham só, já pegam transporte, fazem cursos (...) fazem curso de computação, fazem pintura. (P3)

A história da loucura é marcada pelo controle e pela vigilância como método de "tratamento". Das classes profissionais, à enfermagem foi dado o poder de controlar, disciplinar e educar o doente mental como forma de disciplina, segundo o estabelecimento do vigiar e confinar como instrumentos fundamentais de assistência (BARROS, EGRY, 1994).

Com o novo paradigma de atenção, o da reabilitação psicossocial, a ideia de um louco perigoso que precisa de controle torna-se ultrapassada, e surge a confiança, um "acreditar" nas possibilidades do sofredor.

Devido às conquistas no plano material, possibilitam-se avanços no plano simbólico. A partir da percepção da consciência que os moradores demonstram, surge a possibilidade do 'ir e vir' no plano simbólico, como apresentam os discursos abaixo:

(...) tem o desejo e a gente próprio vai em busca da realização dessa atividade e da realização desse desejo (P1)

São pessoas mais livres. (P2)

Então a gente tem que deixar correr as coisas, ousar, que é possivel sim fazer as coisas. (P2)

Então assim, eles podem escolher: "eu não quero isso". (P2)

(...) mas, nessa (residência) a gente permite mais. (P2)

Ele ta podendo fazer o que normalmente todo mundo faz, sem precisar de ninguém vigiar. 
Para um sujeito que sempre viu cerceados seus desejos, o que significa a possibilidade de fazer o que quiser? Ou quase tudo, já que estamos inseridos em uma sociedade, temos que obedecer a sua imposição de regras. Afinal, nossas escolhas dependem do estado natural, psíquico, cultural e histórico atual, uma vez que não se trata apenas de desejar algo, mas de fazer algo, pois se é livre para realizar algo, só quando se tem o poder de fazê-lo (CHAUÍ, 2006).

Presença de responsabilidade: A noção psiquiátrica do louco como alguém incapaz, foi o que justificou o surgimento da tutela, no campo jurídico, na qual a família se torna responsável civil e materialmente pelo indivíduo que se entende não ter como cuidar e gerir sua vida (AMARANTE, 2003).

No Brasil, a Reforma Psiquiátrica traz um novo olhar sobre esse sujeito que, embasado na Lei ${ }^{\circ}$. 10.216 de 2001, passa a ser tratado com humanidade (o que é contraditório, afinal, somos todos humanos!), ser livre, protegido, ter direitos, características de um ser cidadão. Todavia, passar da dimensão jurídico-política para a sociocultural, envolve um processo social complexo, pois se faz necessário modificar ações, pensamentos e relações sociais (AMARANTE, 2007).

A possibilidade de ter que desenvolver a noção de responsabilidade reflete o avanço da Saúde Mental. Como foi negado durante o tempo de internamento, com a exclusão social, a estigmatização, o direito a ter direitos e deveres, a fazer escolhas, a pensar, trabalhar, a responsabilizar-se por si, hoje os sofredores psíquicos estão em processo de (re)construção da noção de responsabilidade, por isso dentro dessa categoria surge a subcategoria intitulada "Necessidade de desenvolver a responsabilidade", pois, se os moradores não necessitam de uma vigilância constante, precisam desenvolver a responsabilidade sobre si mesmos e exercitá-la.

(...) a gente ainda precisa fazer alguma intervenção, mas a gente tem que ver que eles têm transtorno mental e uma vez por outra um ainda continua tendo crise. (P1) 
(...) é necessário que a coordenação de cuidadores tenha, ainda, uma intervenção. (P1)

(...) dependendo também de terceiros. (P1)

(...) e a gente vai tentando colocar isso em prática com eles. (P2)

(...) a gente tem que trabalhar isso com muita força, para poder eles sair daquele marasmo. (P2)

Responsabilidade de quê? De cuidar de si, de olhar para si mesmo, de querer escolher, de desenvolver alguma atividade. Os loucos foram envolvidos pelo exílio da ociosidade, como se a "preguiça" tivesse sido uma forma de revolta ao trabalho obrigatório das casas de internamento. Com a abertura das grades dos manicômios, reaparece o trabalho propulsor da liberdade (FOUCAULT, 2005).

A Necessidade de desenvolver a responsabilidade apresenta-se também, no discurso dos profissionais, na dependência que os usuários ainda têm da intervenção de um cuidador quando surge uma crise aguda, pois esse sujeito deve receber, segundo o modelo da reabilitação psicossocial, cuidado e uma atenção que seja integral segundo as suas necessidades (AMARANTE, 2003).

A subcategoria "Exercício da prática da responsabilidade" reafirma essa realidade em construção, de sujeito em sofrimento, mas com direitos e responsabilidades que lhe facultam a possibilidade de conquistar níveis de autonomia e emancipação para direcionar sua vida e é ilustrada pelos discursos a seguir:

(...) eles podem dividir tudo por igual, ter responsabilidade, como a questão das despesas. (P1)

(...) eles têm aquela responsabilidade de fazer alguma coisa por eles. (P3) 
(...)saber da responsabilidade do que eles têm que fazer com aquele salário que eles têm. (P3)

(...) ter a responsabilidade de ficar com o cartão dele do benefício. (P3)

(...) sabem toda a responsabilidade da Casa Azul, do que eles gastam, que tem o dinheiro da medicação (...), tem o pão, o gás, a doméstica, eles sabem da responsabilidade deles. (P3)

Essa subcategoria reafirma essa realidade em construção, como pode ser observado nas palavras podem, sabem/saber, têm.

Surge o louco, o "doente mental" e agora o sujeito de direitos vê-se com a possibilidade de administrar sua vida, através da colaboração das técnicas da residência terapêutica. A atenção psicossocial, paradigma da Reforma Psiquiátrica brasileira, fundamenta-se na participação e construção social, que nesta realidade aparece como o saber e o poder agir na sociedade, a partir da vivência, das necessidades e do exercício da responsabilidade de administrar uma casa, o benefício, sua vida.

Relação com a família: Cada sujeito apresenta uma representação de família que está relacionada às próprias experiências, concepções, sentimentos, expectativas vivenciadas, devido à inconcretude deste conceito. No senso comum, a palavra família refere-se àqueles indivíduos ligados por relações consanguíneas que repartem um mesmo lar, contudo, a depender da cultura e da época, tal estrutura sofre variações.

Para definir família é necessário observar as características culturais, econômicas e geográficas da sociedade em questão, além da complexidade humana, por isso não há uma única definição que esgote as inúmeras possibilidades da estrutura em questão. Assim, ao considerarem-na como "um grupo social composto de indivíduos que se relacionam cotidianamente gerando uma complexa trama de 
emoções" (GOMES; PEREIRA, 2005). Tal definição enquadra-se com a realidade presente na residência terapêutica e possibilita a percepção dos sujeitos lá moradores como constituintes de uma família.

Nesse núcleo de sentido fica evidente a necessidade que os moradores têm de se sentirem integrantes de uma família, vivenciando o conflito de sentirem saudade, mas serem desprezados. Aparece nessa categoria, portanto, duas sub-categorias: Saudade da família e Desprezo por parte da família.

Contudo, a representação que os moradores trazem sobre esse núcleo, na visão dos profissionais, está relacionada com seus familiares consanguíneos, com o afeto construído quando conviviam com estes, ocasionando a saudade da família.

(...) a gente vê aquele que sente muita saudade da família, que chora de saudade da família. (P2)

(...) eles sentem muita saudade e muita falta deles (da família) (...) eles choram, assim, tem uns que pioram. (P2)

(...) ele perguntou assim 'Eu tô me tratando com a psicóloga pra quê? Pra eu ficar bom de tudo? Pra eu voltar pra minha família? (P2)

(...) por que eles queriam tá com família. (P2)

Os familiares, muitas vezes, não aceitam seus filhos, irmãos, pais sofredores psíquicos de volta ao lar, por medo da possível periculosidade, do cuidado que terão que dispender, por sentimentos negativos provenientes das experiências passadas, sendo inúmeras as causas que podem ser fornecidas, motivo pelo qual surge a subcategoria "Desprezo por parte da família". 
Pessoas (...) que perderam o vínculo com a família. $(P 1)$

A família poderia ser muito importante nisso (evolução dos usuários), ela não participa, porque ela não quer nem contato com eles, queria o dinheiro, mas não quer muito contato. (P2)

A família quer o benefício, mas não quer nenhum contato com o usuário, ao contrário, o mais longe possivel. (P2)

(...) principalmente a família não acreditava neles. (P3)

Em estudo etnográfico (DALMOLIN, 2006) foram coletados discursos de familiares de sofredores psíquicos que mostram como o conceito psiquiátrico está intrínseco à vida social, quando alguns parentes afirmam não aceitarem que o sujeito seja "solto" do hospital psiquiátrico, devido ao medo, à insegurança que sentem ao tê-lo por perto. $\mathrm{O}$ internamento, nesta visão, funciona para fornecer certa ordem na célula familiar, apresentando o valor de regra social e norma de razão (FOUCAULT, 2005).

$\mathrm{Na}$ realidade da residência terapêutica, os indivíduos que têm contato com a família não são aceitos por esta, contudo fazem parte de outra família, uma vez que participam do cotidiano e da convivência de outro lar, a Casa Azul. Nesse aspecto, o que precisa ser trabalhado é a convivência familiar e conceitos de família enquanto "viver juntos sob o mesmo teto" (GOMES, PEREIRA, 2005).

Administração do próprio dinheiro: Ao louco, foi negada a cidadania, ao lhe ser proibida a capacidade de escolha, anulando-lhe o direito e a responsabilidade, internando esses sujeitos em hospícios, devido à patologia que apresentavam, mas, principalmente, por não poderem participar da vida econômica e social, através do trabalho e do consumo (MACHADO, 2008). 
O internamento ocorrido a partir do século XVII teve como motivo a crise financeira do Ocidente(6). Após o Renascimento, com o mercantilismo, aqueles que não contribuíssem com o comércio e consumo seriam encarcerados. Assim, como os loucos distinguiam-se pela incapacidade ao trabalho, não tinham como participar da vida econômica, do movimento de produção, foram marginalizados da sociedade (SILVA FILHO, 1990).

No movimento atual, pelo menos na perspectiva jurídico-política, os sofredores psíquicos já têm a possibilidade de envolverem-se nas relações sociais, participando da vida econômica e administrando o próprio dinheiro, pois têm direito ao Benefício de Prestação Continuada garantido pela Lei ${ }^{\circ} 8.742$, de 7 de dezembro de 1993, a qual, no Artigo 20, garante um salário mínimo por mês ao portador de deficiência que não pode se manter e cuja manutenção não pode ser fornecida pela família, e ao Programa de Volta para Casa (PVC), um auxílio no valor de $\mathrm{R} \$ 240,00$ para egressos de longas internações psiquiátricas.

(...) eles mesmos fazem feira, fazem pagamentos, vão ao comércio, contratam doméstica para cuidar deles. (P1)

Tem um que tem até cartão de crédito, ele mesmo foi comprar seus próprios objetos pessoais. (P1)

(...) ter cartão de crédito, ter celular, tão muito consumista também, televisor novo, programa de jogos, (...) microondas. (P2)

(...) eles vão pra feira e fazem a feira deles, vão pra panificadora, compram o pão deles. (P2)

(...) poder ir no banco com o cartão dele, tiraro dinheiro dele. (P3) 
(...) (Os moradores da Casa Azul) vai no banco tirar o dinheiro dele, pagar as coisas que ele tem que pagar. (P3)

Eles (...) sentam com a cuidadora e administram o próprio dinheiro. (P3)

Cidadania e economia são peças fundamentais para o desenvolvimento social, pois enquanto aquela é a finalidade para a obtenção da qualidade de vida, acesso segundo as necessidades e justiça social, esta é o meio necessário para obtê-la.

A necessidade de ações concretas para o surgimento de possibilidades verdadeiras para o sofredor psíquico, no sentido de sua inclusão no mercado de trabalho, aponta que é necessário reorganizar as regras sociais para que aqueles em desvantagem social possam compartilhar esse cenário, pois a real inserção social humana só ocorre através do trabalho. Todavia, o grande desafio para esta prática encontra-se no estigma social (HIRDES, 2009).

Significado da 'Casa Azul': A representação que os profissionais fazem do significado dos moradores da 'Casa Azul' revela ainda a presença do paradigma biomédico arraigado à percepção a respeito da obtenção de autonomia pelos moradores. A ideia de doença mental, medicação e crise referem-se ao monopólio psiquiátrico sobre a loucura.

Para os entrevistados, a autonomia dos moradores significa uma redução dos sintomas da "doença mental" que é comparada àquela obtida pelos moradores das demais residências terapêuticas. Todavia, já se visualiza, pelos profissionais, a noção do desejo, da singularidade dos moradores, da vontade em querer mudar, como apresenta os discursos dos sujeitos:

(...) não são tão crônicos enquanto os que residem nas outras residências, eles não tem tanta crise como aqueles outros. (P1) 
(...) (Os moradores da Casa Azul) foram aqueles usuários que conseguiram mais autonomia do que os demais. (P1)

Eles são doentes mentais como os outros são, tomam medicação tudo direitinho. (P2)

Eu acho que eles estavam na outra casa perdidos. (P3)

Por isso, a reforma psiquiátrica é um “processo social complexo", pois articula diversas dimensões que se complementam: a teórico-conceitual, (re)construção dos conceitos sobre a loucura; técnico-assistencial, referente às estruturas de atenção, tratamento, tipo de atendimento fornecido; jurídica-política, quanto a modificações políticas e legislativas sobre a saúde mental; e, finalmente, a sociocultural, que aparece como resultado das demais dimensões, por envolver a transformação do imaginário social (AMARANTE, 2003).

Trata-se de um processo complexo que envolve as diferentes camadas sociais. Modificar o conceito psiquiátrico que envolve a sociedade, há séculos, não é tarefa fácil, mas é atual. Nesse sentido, fazem-se necessárias práticas dinâmicas para que se busque superar a visão psiquiátrica e assumir o paradigma da reabilitação psicossocial como modelo para condução da Saúde Mental.

\section{Para não concluir...}

A construção dos significados da Representação Social da Autonomia dos moradores da 'Casa Azul', segundo os profissionais encarregados da administração do SRT, surgiu através dos núcleos de sentidos contidos nas categorias de análise Capacidade de transitar sozinho; Presença de responsabilidade; Relação com a família; Administração do dinheiro; e Significado da 'Casa Azul'. 
As considerações levantadas expõem que a autonomia no sentido pragmático não foi obtida em sua totalidade. Contudo, a reinserção social dos usuários da Casa Azul é uma realidade. Desse modo, nos discursos dos participantes da pesquisa, a reinserção social aparece como uma unidade de significação estruturante, tendo o papel de criar e modificar o significado dos demais elementos da representação social.

A inserção desses sujeitos no mercado da troca real, monetária, propicia a integração social, e a constatação das possibilidades dos sofredores psíquicos enquanto cidadãos.

Detentores de uma Cidadania em construção, cidadania esta que não remete apenas a posse de direitos, apresentam a liberdade individual de transitar, no plano material e simbólico. Conquista de grande valor frente à realidade psiquiátrica dos manicômios, única alternativa dos "seres enlouquecidos".

Como possuidores de Cidadania, os moradores, agora, podem usufruir da responsabilidade perante si mesmo e à sociedade, necessitando trabalhá-la, devido ao tempo de internamento e à noção de tutela, que lhes retiravam o direito de escolhas.

É visível o sofrimento dos profissionais ocasionado pela ausência de relações dos moradores com as famílias. Esse sentido negativo decorre de duas vertentes que se articulam: um adoecimento dos moradores devido ao desprezo existente por sua família; não compreensão dos familiares da reabilitação psicossocial propiciada pelos serviços substitutivos.

Os sujeitos entrevistados, em suas experiências com as residências terapêuticas, reconhecem peculiaridades nos moradores da 'Casa Azul', as quais atingem várias dimensões das existências destes, contudo, o foco primordial é a evolução nos aspectos relativos ao adoecimento físico, a doença mental, o que revela uma visão cujo paradigma biomédico ainda é preponderante. 
Muitas são as conquistas que estão sendo efetivadas para a mudança na atenção em Saúde Mental, mas por ser um campo recente, o trabalho para sua efetivação está ainda em construção.

\section{Referências}

AMARANTE, P. Saúde mental e atenção psicossocial. Rio de Janeiro: Fiocruz, 2007.

Conceitos e dimensões da Reforma Psiquiátrica. In: Saúde mental, políticas e instituições: programa de educação à distância. Rio de Janeiro: FIOCRUZ, 2003. p. 57-71.

AMARANTE, P. Novos Sujeitos, Novos Direitos: O Debate em Torno da Reforma Psiquiátrica. Cad Saúde Publica, v. 11, n. 3, p. 491-494, 1995.

ANTUNES, S. M. M. O.; QUEIROZ, M. C. A configuração da reforma psiquiátrica em contexto local no Brasil: uma análise qualitativa. Cad Saúde Pública, v. 23, n. 1, p. 207-215, 2007. Disponível em: <http:// www.scielo.br/scielo.php?pid=S0102-311X2007000100022\&script $=$ sci_ abstract\&tlng=pt.> Acessado em: 11 mai 2007

BARDIN, L. Análise de conteúdo. Lisboa: Edições 70, 2006.

BARROS, S.; EGRY, E. Y. A enfermagem em saúde mental no Brasil: a necessidade de produção de novos conhecimentos. Saúde Soc., v. 3, n. 1, p. 79-94, 1994.

BRASIL. Saúde mental no SUS: acesso ao tratamento e mudança do modelo de atenção. Relatório de gestão 2003-2006. Brasília: Ministério da Saúde, 2007. 
. Conselho Nacional de Secretários de Saúde. Legislação do SUS. Brasília: CONASS, 2003.

. Portaria 106/2000 GM, de 11 fev. 2000. Institui os Serviços Residenciais Terapêuticos. Diário Oficial da República Federativa do Brasil, Poder Executivo. Brasília (DF), 21 fev. 2000.

Resolução 196/1996. Dispõe sobre as diretrizes e normas regulamentadoras de pesquisa envolvendo seres humanos. Diário Oficial da República Federativa do Brasil, Poder Executivo. Brasília (DF), 16 out. 1996.

CAMPOS, F. C. B. Relatório sobre o desenvolvimento e gestão de sistemas de serviços de saúde. Campina Grande: Ministério da Saúde, 2005.

CHAUÍ, M. Convite à Filosofia. 13º ed. São Paulo: Ática, 2006.

DALMOLIN, B. M. Esperança Equilibrista: cartografias de sujeitos em sofrimento psíquico. Rio de janeiro: Fiocruz, 2006.

FOUCAULT, M. História da Loucura na idade clássica. $8^{\circ}$ ed. São Paulo: Perspectiva, 2005.

GOMES, M. A.; PEREIRA, M. L. D. Família em situação de vulnerabilidade social: uma questão de políticas públicas. Ciênc. saúde coletiva, v. 10, n. 2, p. 337-363, 2005.

GUIMARÃES, J. et. al. Desinstitucionalização em Saúde Mental: considerações sobre o paradigma emergente. Saúde Debate, v. 25, n. 28, p. 5-11, 2001.

HIRDES, A. Autonomia e cidadania na reabilitação psicossocial: uma reflexão. Ciênc. Saúde Coletiva, v. 14, n. 1, p. 165-171, 2009. 
JODELET, D. Representações do Contágio e a Aids. In: AIDS e Representações Sociais: à busca de sentidos. Natal: EDUFRN, 1998. p. 17-46.

MACEDO, J. Q.; SILVEIRA, M. F. A. The introductive experience of Half-Way Houses - Quantitative and qualitative analysis $\bigotimes$. Online Braz J Nurs., v. 8, n. 2, 2009. Disponível em: <http://www.objnursing.uff.br// index.php/nursing/article/viewArticle/j.1676-4285.2009.2375.> Acessado em: 26 out. 2009.

MACEDO, J. Q.; SILVEIRA, M. F. A. Uma casa, outro tratamento: Análise do Projeto Terapêutico dos moradores dos Serviços de Residência Terapêutica do município. Relatório Final. Campina Grande: PIBIC/ CNPq/UEPB, 2008.

MACHADO, J. S. A. Loucura e cidadania: um lugar possível? CSOnline, v. 3, n. 2, p. 108-121, 2008.

SILVA FILHO, J. F. A medicina, a psiquiatria e a doença mental. In: TUNDIS, S. A.; COSTA, N. R. Cidadania e Loucura: Políticas de Saúde mental no Brasil. $2^{\circ}$ ed. Petrópolis: Vozes, 1990. p. 75-102.

SOUZA, S. R. E. As representações Sociais no campo do conhecimento. Cad. Psicol., v. 6, n. 8, p. 112-120, 1999.

TENÓRIO, F. A reforma psiquiátrica brasileira, da década de 1980 aos dias atuais: história e conceitos. Hist. Cienc. Saúde - Manguinhos, v. 9, n. 1, p. 25-59, 2002.

VICTORA, C. G.; KNAUTH, D. R.; HANSSEN, M. N. A. A pesquisa qualitativa em saúde. Rio de Janeiro: Tomo Editorial, 2001. 



\title{
Uma casa, uma família: a experiência de moradia e de reconstrução dos "laços de parentesco" na residência terapêutica
}

\author{
Hudson Pires de Oliveira Santos Junior \\ Maria de Fátima de Araújo Silveira \\ Dulce Maria Rosa Gualda
}

\section{Que casa? Que família?}

O nosso desafio neste capítulo é descrever e analisar o processo de organização e reconstrução de laços afetivos e familiares de sofredores psíquicos que habitam uma residência terapêutica. Todavia, antes de adentrarmos no seio desse lar, é de fundamental importância a reflexão sobre o significado de família, pois a ideia de que a família é o contexto social de grande relevância, no que diz respeito à saúde mental, encontra-se presente em variados estudos.

Para fundamentar essa discussão, trazemos o conceito de família como uma unidade cujos membros podem ou não estar relacionados ou viver juntos. Nela, existe um compromisso e um vínculo entre seus membros e as funções de cuidado consistem em "proteção, alimentação e socialização” (BOUSSO, ÂNGELO, 2001). 
Então, entende-se a família como um porto seguro, contudo, as concepções sobre a mesma vêm sofrendo significativa transformação, cujo fundamento contemporâneo não significa, agora, tão-somente laços sanguíneos, não tem a ver com bases materiais, com tecnologia, com fronteiras da terra ou do limite da vida. Contudo, a família, independentemente de ser patriarcal ou monoparental (de mães sozinhas), pobre ou rica, conservadora ou liberal, hétero ou homoparental (regida por homossexuais), tradicional ou pós-moderna, é o pilar que sustenta a sociedade (PACHECO; TRISOTTO, 2006).

Nesse entendimento, outro elemento que sofreu uma significativa transformação foi a casa. Para a família tradicional, a casa era um símbolo muito forte, porque representava a união e a proteção. Inclusive, sabe-se que algumas famílias antigas eram reconhecidas por seu brasão, uma espécie de símbolo dos laços de sangue e da importância dos valores que perduravam por gerações. Antigamente era nela, na casa, que todos se reuniam, que compartilhavam espaços, que se juntavam ao redor da mesa nas refeições, conversavam nas varandas, comemoravam casamentos ou ainda velavam seus mortos. Enfim, a casa, além de ser um elo de ligação dos familiares, era o símbolo sagrado da família. Era o casulo e o limite (PACHECO; TRISOTTO, 2006).

Porém, não se pode desconsiderar a sobrecarga que recai sobre os familiares por terem de acompanhar e cuidar de um membro adoecido mentalmente. Essa sobrecarga advém do medo, da responsabilidade como o cuidado, da culpa, da frustração, enfim, da dificuldade de lidar com a complexidade que envolve a situação (WEYLER, 2006). Tal processo desperta na família os mais variados sentimentos, entre eles, o da penalização, o da insegurança, da impaciência e da necessidade de transferir para outrem - até então, o hospital psiquiátrico - a responsabilidade pelo cuidado do seu parente.

Tais hospitais são marcados como barreira entre os internos e à relação social com o mundo externo, através do evitamento de relacionamentos pessoais satisfatórios, falta de assistência humana 
básica e excessiva medicalização. Foucault (2004) descreveu em seu livro "História da Loucura", que o acontecimento seguinte a internação psiquiátrica é a perda de documentos, objetos pessoais, contato, dignidade, lembranças, laços familiares e sociais, restando, no fim, apenas "o escuro e a solidão".

Por isso, concordamos com a afirmação de que "os manicômios, além de serem miseráveis, são também vazios de relações afetivas" (SARACENO, 1999). Por essa e por outras razões, o motivo declarado da Reforma Psiquiátrica é evitar que o sujeito em sofrimento psíquico seja privado de seus laços afetivos e sociais.

Todavia, fica difícil para a família não trabalhada incorporar essa nova proposta da Reforma, a qual assegura que o sofredor psíquico deve ser atendido no contexto social e familiar e por meios menos invasivos possíveis. Logo, há a premência de se ofertar suporte terapêutico para que os familiares possam cuidar, proteger e aliviar-se da sobrecarga vivida, possibilitando-lhes a construção de novos caminhos para lidar com seus sofredores psíquicos de forma mais livre e autônoma.

É tomando o sentido dessa última frase, que interrogamos: o que é a casa e como é "habitá-la" para os sujeitos que viveram parte (muitas vezes, a maior) de suas vidas internos em instituições psiquiátricas, isolados de sua família? Qual será o sentido de moradia em seu imaginário? O hospital se pronunciava (ou se pronuncia) como o habitar seguro ou como o mundo exterior, adverso e hostil?

Levantar tais questões é um desafio, talvez nunca saibamos, de fato, dar as respostas, mas já é um grande passo refletir sobre a problemática, não apenas do sentido de habitação para sujeitos que passaram por internações psiquiátricas, mas das condições como essas pessoas são (eram?) tratadas nos manicômios, configurando-se como um espaço de mortificação e de cronificação do sujeito social, pois são privados da liberdade de circulação pela comunidade, per- 
dendo a capacidade de escolher sobre sua trajetória de vida, ficando à mercê do saber institucional e psiquiátrico.

Atualmente, muitos sujeitos egressos de instituições psiquiátricas habitam as Residências Terapêuticas ou Moradias, dispositivos para redução de internações manicomiais, configurando-se como alternativas, seja pelo suporte requerido para garantir sua permanência fora dela, seja pela dificuldade de reinserção familiar.

Diante do exposto e levando em consideração que a Organização Mundial de Saúde (OMS) usará a Reforma Psiquiátrica brasileira como modelo internacional para a saúde mental, sendo tal decisão parte do Mental Health Gap Action Program (mhGap) - estratégia global que tem por objetivo melhorar o acesso ao tratamento para transtornos mentais, neurológicos e aqueles relacionados ao consumo prejudicial de drogas (ENSP, 2009).

Entendendo-se que a Reforma Psiquiátrica ousa transformar práticas de saúde com o intuito de construir novos saberes, este estudo teve por objetivo: conhecer como se dá o modo de vida dos moradores da Residência Terapêutica Mista; quais as relações que se estabelecem entre eles no cotidiano; e quais papéis assumem na casa.

\section{Construindo o alicerce para entrar na casa}

O estudo foi realizado na Residência Terapêutica Mista localizada na cidade de Campina Grande, no interior do estado da Paraíba, Brasil. Como colaboradores da investigação estão 07 moradores da Residência Terapêutica Mista e 03 profissionais que atuam/circulam nesta moradia.

No cenário atual, a cidade possui uma rede ampla de serviços substitutivos ao hospital psiquiátrico: 01 Centro de Apoio Psicossocial (CAPS II, atendimento diuturno), 01 CAPS III (atendimento 24 horas), 02 CAPSi (atendimento a crianças e adolescentes), 
01 CAPSad (atenção à saúde de sujeitos alcoolistas e usuários de outras drogas), 01 Unidade de Emergência Psiquiátrica, 01 Centro de Cultura e Lazer, 09 miniequipes de saúde mental nas Unidades Básicas da Estratégia Saúde da Família (ESF), 06 Residências Terapêuticas e 41 usuários credenciados no Programa de Volta para Casa.

Atualmente, as residências terapêuticas se articulam com a rede substitutiva da seguinte forma: no cotidiano, os moradores vão ao Centro de Atenção Psicossocial de referência da sua residência, sendo este definido pelo critério da territorialidade: as residências masculina I (08 moradores), feminina I (08 moradoras) e masculina III (07 moradores) têm como apoio o CAPS II; a residência masculina II (07 moradores), feminina II (07 moradoras) e mista (07 moradores/as) se referenciam com o CAPS III. Nestes centros, duas vezes por semana, participam de oficinas, interagem com outros usuários, desenvolvem trabalhos artísticos, bem como praticam atividades físicas. O Centro de Convivência é um local utilizado pelos moradores das residências, bem como por outros usuários da rede de saúde mental, para o lazer e profissionalização - cursos de computação, artesanato, reciclagem - além de permitir que os mesmos entrem em contato com a comunidade, por ser um espaço aberto ao público.

\section{Preparado o alicerce, adentramos no seio desse lar}

A priori, pode-se afirmar que a atenção aos sofredores psíquicos produzida no âmbito domiciliar, por se tratar de um espaço de moradia, uma "casa", pode ser um dos disparadores da produção de vida e saúde, possibilitando oportunidades de inclusão social e reconstrução de cidadania perdida ou nunca alcançada. Essas novas práticas de saúde, no campo da saúde mental, buscam transcender a psiquiatria tradicional, promovendo uma valorização do sujeito e uma re-elaboração da identidade e de seu espaço social, favorecendo 
a autonomia, os vínculos sociais e familiares e outra percepção de vida (BELINI; HIRDES, 2006).

Contudo, para essa progressiva inclusão social, cada residência terapêutica deve ser considerada única, sendo organizada segundo as necessidades, gostos e hábitos de seus moradores, sempre visando a oferecer vivências enriquecedoras, que promovam maior capacidade para eles enfrentarem os desafios da vida (OLIVEIRA; FORTUNATO, 2003). Pois, como dizem Weyler e Fernandes (2005), os indivíduos que passam a viver em uma casa, como as residências terapêuticas, experimentam uma dupla inserção: 1) são usuários de uma rede extra-hospitalar de atenção à saúde mental pelo enfoque psicossocial, onde também é realizado o acompanhamento terapêutico; 2) e são donos, moradores da casa, onde têm a possibilidade de resgatar as funções fundamentais do morar, de acordo com suas histórias de vida e com as relações que se estabelecem.

Todavia, a história dos moradores das Residências Terapêuticas Mista, foco deste estudo, foi marcada pelas internações em hospitais psiquiátricos, caracterizadas por barreiras à relação social e com o mundo externo: pela ausência de relacionamentos pessoais satisfatórios, falta de assistência humana básica e excessiva medicalização.

Logo, a saída de um sujeito do hospital psiquiátrico e sua ida para a residência terapêutica é o começo de um longo processo de reabilitação, que objetiva buscar a progressiva inclusão social do morador e sua emancipação pessoal; afinal, sua finalidade principal é a moradia, o morar e o viver na cidade, levando-se em consideração que as residências são centradas no modelo humanista.

Bem! Essas pessoas saíram do João Ribeiro [hospital psiquiátrico] por causa de maus tratos e as pessoas quando vem visitar comentam que mudou muita coisa, até em termos assim..., tinha muitos deles que não usavam roupas, eram sempre pelado. Uns nem falavam, como 
tem um que ele nem saia do quarto, depois que ele veio aqui pra Residência ele sai, ele ouve música, assiste televisão. (P1)

A narrativa aponta a desassistência ao sujeito em sofrimento psíquico no modelo asilar, bem como as modificações no modo de vida deles após terem ido morar nas residências, espaços de habitar que atuam como potencializadores da produção de vida e saúde, favorecendo a progressiva inclusão social, através do resgate da autonomia e do processo de reabilitação social.

Essa história de escovar dentes, tomar banho, eles já fazem só, que é um avanço muito grande, porque [quando] eles saíram do hospital, não conseguiam fazer isso de maneira nenhuma. (P3)

Pra ser sincera, eles já melhoraram muito, de sentar, de comer, de tomar água, banho. Eles só tomavam água na torneira, agora já pega um copo e vai à geladeira. (P2)

Diante das narrativas, pode-se dizer que o início do processo na residência é complexo, primeiro devido à cronificação dos moradores, causada pelo processo de segregação na instituição psiquiátrica; segundo, pela resistência da comunidade em aceitar que casas comuns nos bairros estavam sendo alugadas para servir de moradia para "loucos" saídos do manicômio, culminando em alguns movimentos como abaixo-assinados; terceiro, pela própria insegurança dos profissionais de ficar à frente de uma proposta tão ousada quanto às residências terapêuticas.

Esse último fator ficou ainda mais evidente quando surgiu a proposta de montar uma casa para habitar homens e mulheres, sendo chamada de Residência Terapêutica Mista, ficando a equipe técnica insegura pela questão da sexualidade dos moradores e temerosa das 
possíveis consequências dessa convivência, afinal, tais profissionais já vinham marcados pelo imaginário da instituição total (manicômios, prisões e conventos), descrito por Goffman (2003), onde os internos devem ser segregados por sexo, impedindo uma possível relação entre casais.

Em uma residência terapêutica mista, além de todos os desafios já explícitos para a atenção substitutiva ao hospitalocentrismo, tem-se outro desafio: a vivência da sexualidade de homens e mulheres. Não apenas porque convivem em uma mesma casa, mas porque essa foi uma das dimensões humanas mais reprimidas no modelo asilar. A abordagem da sexualidade ainda assusta a equipe, que não está capacitada para tal. Esta lacuna começa a tomar forma na graduação e prossegue nas "capacitações continuadas" ou na sua sucedânea, “educação permanente".

O preconceito evidente sobre a sexualidade do sofredor psíquico é parte de um mascaramento social ou uma negação maior e fora do âmbito dos direitos. Tal negação reproduzida no contexto institucional e profissional representa apenas um fragmento do pensamento da sociedade. Para Foucault (2007), a sexualidade trata-se de um dispositivo histórico de poder, pois normaliza a vida do indivíduo e, consequentemente, de todo o corpo social.

Olhe! Digo a você que quando lançou essa proposta: vamos abrir novas residências, dentre estas vai ter uma mista, fiquei meio insegura. Nossa e aí? Puxa vida! Mista? Como vai ser essa convivência? Homem e mulher? Acho que vai ser super difícil. Será que vai dar certo mesmo? Então, essa coisa normal de insegurança, medo mesmo, e aí como é que vai ser o dia-a-dia? Mas por incrível que pareça, é a casa melhor que tem. (P1) 
Apesar da insegurança, a moradia foi criada e, ao invés de ocorrer o que a maioria temia: os moradores fazendo sexo todo o tempo, em todos os locais da casa, sem nenhum preceito - pois se imagina o "louco" como um sujeito sem controle sobre seu desejo sexual, os fatos não ocorreram como o previsto. Os moradores não estabeleceram relações de casais, não despertaram ou não expuseram nenhum tipo de relação que não fosse a de amizade, de confiança e respeito mútuo necessário para a boa convivência em grupo.

Quando eu vi aquela turminha ali pensei que ia ser mais difícil, mas quando passaram para a convivência da forma deles, eles se entrosam. Isso tem que ser levado em consideração, mas a gente percebe que existe algo maior, que é a amizade entre eles. Eles participam da vida um do outro, eles conversam entre si, a gente percebe que existe uma afinidade entre eles, a gente percebe que eles estão bem, existe uma busca, está em construção. (P2)

Eu gosto do pessoal que mora aqui comigo, me sinto segura, né? Eu cuido deles, a gente conversa, assiste televisão, escuta música no rádio de um dos moradores. É muito bom aqui! (M6)

Tais fatos ganharam sentido no período de observação, no qual notamos que a dinâmica relacional desses sujeitos se assemelha a uma "estrutura de família", onde se encontram presentes relações de afeto, de cuidado um com outro, de proteção e até de conflito, comum em toda casa. Além disso, foi possível observar que os moradores não possuem relacionamento amoroso/sexual. Ao invés, parecem reproduzir o tabu universal do incesto, que é a condenação deste tipo de relacionamento entre familiares.

O incesto é um conjunto de regras, costumes, estipulações e instituições, que condena a relação sexual ou marital entre parentes 
próximos ou alguma forma de restrição sexual dentro de determinada sociedade. É um tabu presente em quase todas as culturas humanas, sendo, por isso, considerado universal. Em alguns casos, é punido como crime; em outros, é considerado pecado (como o é para as religiões históricas do mundo). $\mathrm{Na}$ maior parte dos países, o incesto é legalmente proibido - mesmo que haja consentimento de ambas as partes. A repugnância em relação ao incesto explica-se pelo papel negativo dos hábitos cotidianos sobre a excitabilidade erótica. De fato, o incesto é proibido pela lei e pelos costumes - cultura (LÉVI-STRAUSS, 2008).

Contudo, essa proibição não se prende apenas à exogamia entre parentes próximos, mas, juntamente com eles, um número considerável de indivíduos dentre os quais não é possível estabelecer nenhuma relação de consanguinidade ou de colateralidade. Isso ocorre devido ao que se incorpora no imaginário como sendo parentesco e família (LÉVI-STRAUSS, 2008).

Não quero não! Deus me livre, aqui dessa casa não namoro com ninguém, não. (M4)

As narrativas mostram aversão dos moradores por estabelecerem relacionamento amoroso entre eles, porém não os impedem de gostar e namorar outras pessoas, fato constatado nas suas falas e nas dos profissionais:

Nessa casa aqui, eles não tem relações. Mas, M4 tem namorado, namora com $D$. da outra residência, começou lá na Unidade de Emergência; e M7 com G., agora... entre eles aqui, não, Eles não se agradam muito, não [risadas]. (M3)

Eu tenho D. [usuário de outra RT], aquele bicho gordo, pia [olha] aqui a aliança. Eu namoro com ele. Oie [olhe], eu vou casar! (M4) 
A sexualidade também é expressa através da necessidade de passeios noturnos pelos homens - a ida a casas noturnas, onde podem conhecer e se relacionarem com mulheres, pagando por isso.

Alguns usuários têm passeio noturno. Não são todos, mas alguns fazem. Passeio noturno é o contato com mulheres, então não são todos que tem condição disso e eles pedem, pedem isso. A gente providencia camisinha, esse tipo de coisa! (P1)

Outra expressão da sexualidade é a vivência homossexual:

Sabe de uma coisa? Eu gosto mais de homem do que de mulher, mas eu não gosto de falar isso a todo mundo. (M10)

Para Foucault (2007), na instituição psiquiátrica, a imagem corporal do/a interno/a é desprovida de beleza e vigor físico. Ali, a negação da sexualidade do adoecido mentalmente coaduna-se com a noção de desvio, por ser indicativo de estigma, o qual marca o sujeito; acusa, censura e condena, sendo comumente, reconhecido como capaz de auto e/ou heteroagressão. Para impedir foi/é realizado o controle por via da interdição e da proibição: separando-se os internos em alas masculinas e femininas, e com os cuidados a cargo de profissionais do mesmo sexo de cada ala específica, práticas que, por vezes, é terreno fértil também para a vivência de uma homossexualidade "induzida" pelas circunstâncias.

Devido a esse fato, afirma-se que, de modo geral, a homossexualidade não é percebida como uma estrutura específica dos sofredores psíquicos, mas como um conjunto de práticas ligadas à situação, à separação entre os sexos e à inibição de origem institucional (GIAME, 2004).

Giame (2004), tomando por base a análise de Erving Goffman sobre instituições totais, afirma que o objetivo maior dessa lógica 
"total" é impedir a possibilidade de relações heterossexuais e o estabelecimento de uma vida de casal. Esta lógica tem como efeito secundário o fato de tolerar, ou mesmo favorecer, as relações entre as pessoas do mesmo sexo, a prática da masturbação e o consumo de pornografia, que constituem características da vida sexual institucional.

Porém, apesar do homossexualismo ser uma realidade constante nas relações sociais, ainda se trata de um tema marginalizado, de pouca aceitação pela sociedade e de difícil discussão, devido à resistência em se falar sobre o tema.

Para esclarecer melhor o tema da sexualidade, apresentamos a concepção, a qual afirma que esta dimensão humana não está reduzida ao exercício da sexualidade genital, mas inclui a vida afetiva, o carinho, a alegria, a expressividade e tantas outras formas, permitindo uma apreciação extensa e com as nuances da realidade (GIAME, 2004). A sexualidade, como expressão humana, é uma experiência pessoal, embora universal a todos os seres, pois é fruto de uma construção única de cada ser. Geertz (1989), trabalhando com uma perspectiva cultural, afirma que a sexualidade se apresenta na maneira como pensamos, sentimos e agimos. Ela está relacionada a todos os aspectos de nossa vida, sendo entendida, portanto, como o resultado de uma construção histórica, social e cultural singular, que se integra e se manifesta através da rede de significados do grupo social específico, possibilitando toda a expressão relativa ao sexo.

Voltando para os discursos dos colaboradores deste estudo, não se encontram evidências de relacionamentos sexuais entre eles. Até ao contrário, a repetição de narrativas deixam entrever certa aversão no que tange à possibilidade de relacionarem-se entre si. É importante notar a veemência com que negam ter um relacionamento com outro morador da casa, reproduzindo, assim, o tabu universal do incesto. 
Assim sendo, a importância de tais considerações reside no fato de que, com isso, é possível visibilizar dobras onde podem estar presentes, de forma velada ou expressa, a tentativa ou experiência concreta de estruturação de uma nova "família”. Para tal, é necessário preservar esse tabu, que surge aqui para além da universalidade de uma prática. Isso demanda uma outra discussão, que tem agora como foco a representação de família em si, como um conceito universal utilizado para definir a união de um grupo social em torno do parentesco, o que pode ocorrer nos mais variados arranjos possíveis.

\section{É no interior do lar que se revelam as relações dos seus moradores}

No que diz respeito ao cotidiano da casa, podemos descrever que os moradores assumem papéis diferenciados, apontando representações de gênero na manutenção das atividades domésticas. Tal fato reforça a concepção de relações familiares de Lévi-Strauss (2008), sobre a atuação no espaço público destinada apenas aos homens, enquanto a cultura de determinadas sociedades destina às mulheres a responsabilidade pelo espaço privado. Esta divisão das atividades é fundamental para evidenciar os pontos de atuação por gênero, mas não significa exclusividade e proibição. Portanto, homens e mulheres podem, em algum momento, assumir a mesma tarefa.

Olha só! Eu trabalho aqui, aqui mesmo. Eu varro o quintal, coloco água nas plantas no quintal, eu subo [no telhado] e tiro as folhas. (M4)

Quando precisa, eu vou comprar as coisas no mercadinho, não fica muito longe. No domingo, a gente sempre compra refrigerante para almoçar. (M6) 
Eu lavo o banheiro bem direitinho eu faço bolo, faço lasanha, faço tudo. Lavo os pratos e coloco as roupas para enxugar. (M5)

Na residência mista, os homens encontram-se mais responsáveis pelo cuidado com o ambiente externo a casa, em providenciar os suprimentos que faltam diariamente. Dessa forma, mantêm a divisão sexual do trabalho, pois as suas atividades são extras a casa, ainda que isso signifique trabalhar no jardim ou quintal. As mulheres assumem a responsabilidade em cuidar das tarefas como cozinhar, lavar e passar. Porém, presenciamos alguns dos homens lavando as louças após as refeições. Pode-se afirmar que a organização da casa vem fazendo com que todos assumam atividades cotidianas e sociais necessárias para a vida em comunidade.

Essa divisão encontra-se estampada no acordo que orienta a organização e distribuição de tarefas no cotidiano na moradia, já que é socialmente mais justo que todos contribuam com as atividades. Dessa forma, a reinserção social visa, também, à reconstrução de relações baseadas em outra ética. Uma parte dos relacionamentos estabelecidos na residência pode ser retratada através das narrativas:

Aqui eles são muito amigos. Até agora, eu não vi discussões entre eles. Eles são assim, de dividir as coisas quando tem. Um empresta o outro. Eles são assim, carinhosos um com outro. Eles conversam bastante, brincam, às vezes. Porque ocorre quando eles não tão nos dias bom deles, às vezes, assim... eles cismam. Mas não tem essa coisa de tá brigando, não. (E3)

Já faz mais de 2 anos que estão juntos. Aí, eles tão mais acostumados. Todos os dias, já faz parte, faz parte como uma família, mais do que realmente a família de alguns deles. Quando um sabe fazer uma coisa, ajuda o outro que ainda não sabe. As decisões da casa sempre parte deles. (E2) 
Apoiando-se na concepção de estruturas familiares de LéviStrauss (2008), este estudo segue com o entendimento de família em seu significado mais amplo, fazendo-a presente em todas as possíveis comunidades estudadas. A família existe, o que difere são as suas formas organizativas dentro do grupo de parentesco.

Pois, o termo família amplia-se ou retrai-se em cada sociedade estudada. Pode ser extensa, abarcando as mais diversas figuras da comunidade, como amigos próximos ou compadres, ou restringir-se a pai, mãe e filhos. Ressalte-se que a existência e acomodação do termo família para as mais infinitas comunidades estudadas, sobre a ótica do parentesco, permitem perceber a importância de tal instituição dentro da sociedade.

Importante, portanto, é ter clareza de tal processo, pois quando um grupo de moradores institui a sua família no interior da Residência Terapêutica, faz isso como parte da sua reinserção social, sendo esta uma das metas almejadas pela Reforma Psiquiátrica. Essa ainda parece ser uma luta "intra casa", uma vez que eles/as ainda enfrentam os muros sociais, esses mais profundos, arraigados e de difícil mudança, posto que foram construídos e solidificados no caldo da cultura no qual estão imersos.

Segundo Anderson (2007), a família é um sistema social uno, composto por um grupo de indivíduos, cada um com um papel atribuído e, embora diferenciado, consubstancia o funcionamento do sistema como um todo. O conceito de família, ao ser abordado, evoca obrigatoriamente, os conceitos de papéis e funções, como se têm vindo a verificar nesta pesquisa, onde os homens assumem as atividades no espaço público e que necessitam de maior força, e às mulheres cabem a responsabilidade com o espaço privado, como limpeza, alimentação, dentre tantas.

Por fim, pode-se dizer que se encontram presentes no cotidiano do relacionamento dos moradores da residência as seguintes funções familiares: geradora de afeto; proporcionadora de segurança 
e aceitação pessoal, promovendo um desenvolvimento natural do sujeito; proporcionadora de satisfação e sentimento de utilidade, através das atividades cotidianas de manutenção da casa; asseguradora da continuidade das relações, proporcionando vínculos duradouros de amizade e confiança; proporcionadora de estabilidade e socialização, assegurando o relacionamento na comunidade; impositora da autoridade e do sentimento do que é correto, relacionado com a aprendizagem das regras e normas, direitos e obrigações características das sociedades humanas.

Para além destas funções citadas, acrescenta-se, ainda, uma função relativa à saúde, na medida em que a família protege a saúde dos seus membros, dando apoio e resposta às necessidades em situações de doença. A família, como uma unidade, desenvolve um sistema de valores, crenças e atitudes face à saúde e doença, que são expressas e demonstradas através dos comportamentos de saúde-doença dos seus membros (estado de saúde da família).

Além disso, diz-se que a família tem como função primordial a de proteção, tendo, sobretudo, potencialidades para dar apoio emocional para a resolução de problemas e conflitos, podendo formar uma barreira defensiva contra agressões externas. A família ajuda a manter a saúde física e mental do sujeito, por constituir o maior recurso natural para lidar com situações potencializadoras de estresse associadas à vida na comunidade (STANHOPE, 1999).

Contudo, nem sempre isso foi assim. Na época em que a residência terapêutica foi inaugurada, os profissionais tinham uma visão reducionista dos egressos do hospital. O que foi mais um avanço romper com a visão biomédica, tecnicista e estigmatizante e se abrir aos novos olhares da abordagem holística e psicossocial.

Então eu digo a você que antes eu vislumbrava o louco de uma forma muito reduzida, pequena. Então, hoje a partir do momento que eu convivo mais com eles. Eu enxergo eles como 
ser humano mesmo. Antes não, eu olhava como se fosse uma coisa qualquer. Uma pessoa que não tinha desejo, que não tinha um significado maior e hoje em dia eu percebo que estava enganada. (P3)

Quiçá, essa reconstituição de um ambiente mais afetivo e familiar seja o que os moradores da residência terapêutica mista precisavam para conseguir recursos de vivência necessários para enfrentar a instabilidade psíquica, que marcou sua história de vida.

\section{Então, o lar abriga o devaneio, mas também a realidade}

O estudo nos conduziu a pontos importantes que permeiam o processo de moradia na Residência Terapêutica Mista, sendo a mesma evidenciada como um espaço intermediário para o convívio social e para o estabelecimento de vínculos familiares, perdidos pelos longos anos de internações psiquiátricas. Esse processo vem possibilitando uma ressignificação do morar, de pertencer à comunidade e, ao mesmo tempo, devido a ele, a de (re) construção do parentesco, gerando novas possibilidades anti-hegemônicas de compreender o sofrimento psíquico, favorecendo as vivências necessárias para a manutenção da estabilidade psíquica dos moradores, promovendo, então, a inclusividade e produção de cidadania.

Acreditamos que as particularidades que foram encontradas nesse estudo, poderão contribuir para nortear as atuais políticas, programas e serviços de atenção à saúde, entendidas na visão ampliada, na qual se insere a dimensão mental dos sujeitos sociais. Porém, temos a clareza de que os resultados aqui apresentados não esgotam a possibilidade de estudo sobre as Residências Terapêuticas, mas sim, abrem novos horizontes para os vários signos e significados que rodeiam essa prática de cuidado domiciliar e de vida em uma família possível. 
Então, a reconstrução do parentesco para os moradores da residência - que vem se configurando como um modelo de auxílio terapêutico - é mais uma barreira que eles precisam superar no itinerário das (mais) perdas e (menos) ganhos causados pelo sofrimento psíquico.

\section{Referências}

ANDERSON, K. K. S. Lugar de mulher é em casa? Cotidiano, espaço e tempo entre mulheres de famílias de pescadores. 2007. 124f. Dissertação (Mestrado em Sociologia). Centro de Filosofia e Ciências Humanas Universidade Federal do Pará. Belém: UFPA, 2007.

BELINI, M. G.; HIRDES, A. Projeto morada São Pedro: da institucionalização à desinstitucionalização em saúde mental. Texto Contexto-Enferm., v. 15, n. 4, p. 562-569, 2006.

BOUSSO, S. R.; ÂNGELO, M. Fundamentos da assistência à família em saúde. Manual de Enfermagem - Programa de Saúde da Família. São Paulo: Ministério da Saúde/USP, 2001.

ENSP. Escola Nacional de Saúde Pública Sergio Arouca. OMS convida Brasil para ajudar em reforma psiquiátrica internacional. FIOCRUZ: Informe ENSP; 2009. Disponível em: <http://www.ensp.fiocruz.br/portalensp/noticia/index.php?id=17343>. Acessado em: 30 jul. 2009.

FOUCAULT, M. História da Sexualidade: a vontade do saber. $18^{\circ}$ ed. Rio de Janeiro: Graal, 2007.

FOUCAULT, M. História da loucura. $8^{\circ}$ ed. São Paulo: Graal, 2004.

GEERTZ, C. A. Interpretação das culturas. Rio de Janeiro: Livros Técnicos e Científicos, 1989. 
GIAME, A. O anjo e a fera: sexualidade, deficiência mental, instituição. São Paulo: Casa do Psicólogo: 2004.

GOFFMAN, E. Manicômios, prisões e conventos. $7^{\circ}$ ed. São Paulo: Perspectiva, 2003.

LÉVI-STRAUSS, C. As estruturas elementares do parentesco. $4^{\circ}$ ed. Petrópolis: Vozes, 2008.

OLIVEIRA, F. B.; FORTUNATO, M. L. Saúde Mental: reconstruindo saberes em enfermagem. Rev Bras Enferm., v. 56, n. 1, p. 67-70, 2003.

PACHECO, E.; TRISOTTO, E. A nova casa: arranjos familiares pósmodernos. Revista Eletrônica Uniter.com, v. 20, n. 2, 2006. Disponível em: <http://www.grupouninter.com.br/revista/anteriores/index.php@ edicao_id=20\&menu_id=4\&id=410 >. Acesso em: 28 set. 2009.

SARACENO, B. Libertando identidades. Rio de Janeiro: Te coroa, 1999.

STANHOPE, M. Teorias e Desenvolvimento Familiar. In. STANHOPE, M.; LANCASTER, J. Enfermagem Comunitária: Promoção de Saúde de Grupos, Famílias e Indivíduos. $1^{\circ}$ ed. Lisboa: Lusociência, 1999. p. 492514.

WEYLER, A. R.; FERNANDES, M. I. A. Os caminhos das propostas de moradias para ex-pacientes psiquiátricos. Vínculo, v. 2, n.2, p. 80-88, 2005. 



\section{Uma delicada ponte entre o passado e o presente: percepções do cuidar/cuidado elaboradas pelos moradores das residências terapêuticas}

Mércia Maria de Paiva Gaudêncio Thatianna Lira Silva Claudia Santos Martiniano

Pensar sobre o cuidar se constitui como uma reflexão que incide em nossas vidas - seja no plano pessoal ou profissional - modulando, reformando e instituindo visões do mundo. Do ponto de vista pessoal não é difícil constatar que estamos sempre a "contar" a história dos cuidados que recebemos ou deixamos de receber. De comum nesses relatos, a fundante presença/ausência de um cuidador e/ou de uma cuidadora. Os protagonistas das histórias particulares de cuidados são, normalmente, entes queridos a quem, pelo resto de nossas existências, chamaremos de significativos.

Se nos permitimos pensar sinteticamente o cuidar em nossa história pessoal, podemos, de forma semelhante, tentar traduzir os sentidos que influenciaram nossa escolha profissional. Ao escolhermos a Enfermagem por profissão, assumimos todos os bônus e ônus que a prestação de cuidados determina na existência daqueles que a esse fim se dedicam. 
No entanto, a questão central que guiou a elaboração deste texto, não diz respeito a nossa história pessoal de cuidados, nem aos determinantes de nossa escolha profissional. Preocupamo-nos, enquanto cuidadores profissionais, em compreender os sentidos que os portadores de transtornos mentais atribuem ao cuidar e aos cuidados. Necessário situar que nos dedicamos a investigar os sentidos elaborados por portadores de transtornos mentais que permaneceram, por longo tempo, internos em hospitais psiquiátricos e que hoje, em decorrência da Reforma Psiquiátrica, moram em residências terapêuticas.

Posto o problema que nos motivou a realizar este estudo, objetivamos, primordialmente, apreender as percepções elaboradas pelos moradores das residências terapêuticas acerca do cuidar/cuidado. Para tanto, abordamos a questão qualitativamente, indo a campo explorar e descrever o fenômeno estudado.

A população investigada se constituiu por um total de 45 portadores de transtorno mental severo, que moravam nas seis residências terapêuticas existentes na cidade de Campina Grande, PB. Convém esclarecer que todas as residências integram a rede municipal de assistência à saúde mental, sendo duas destinadas à população feminina, três a população masculina e uma é mista.

A amostra foi constituída por 21 pessoas que atenderam aos critérios estabelecidos para inclusão no estudo, quais sejam: ser morador de uma das residências terapêuticas por um período de tempo superior a seis meses; apresentar capacidade de comunicação preservada, condição mental de compreender perguntas e emitir respostas e dispor-se a participar da pesquisa.

Em acordo com as determinações da resolução CNS 196/96, o projeto de pesquisa foi encaminhado ao Comitê de Ética em Pesquisa da UEPB sendo, após a anuência desse órgão, iniciadas as articulações para a coleta dos dados. 
Os dados foram coletados nas residências mediante a realização de entrevistas previamente agendadas. As entrevistas foram conduzidas através de questões norteadoras, que visaram a contemplar o enunciado do problema e o objetivo proposto. As entrevistas foram gravadas em $m p 3$ e posteriormente transcritas pelas pesquisadoras.

Os discursos foram analisados através dos procedimentos propostos pela análise de conteúdo temática (BARDIN, 2006). Para tanto, os discursos foram recortados em unidades de análise e reorganizados, o que nos possibilitou identificar categorias discursivas que viabilizaram a apreensão dos sentidos coletivamente atribuídos ao cuidar/cuidado.

Para produzir inferências e ancorar a análise do material coletado entendemos ser necessário abordar três perspectivas teóricas que circunscrevem a temática investigada: o cuidar e os cuidados, o sofrimento psíquico e as residências terapêuticas.

\section{Digressões sobre o cuidar/cuidados}

Embora possamos sobre tudo aquilo que nos rodeia, exercitar o cuidar, o objeto em estudo demanda que observemos com atenção o cuidar e os cuidados que se projetam sobre os homens, em particular, quando mentalmente perturbados.

Para tanto, inicialmente, aproximamo-nos das ideias de Bison (2003), quando afirma que o homem é um projeto infinito. Lembranos o autor que o infinito não se enquadra em qualquer lógica, obrigando-nos a refletir sobre nossa condição de sistema aberto, apto a novas incorporações e vivências.

Pensando sobre a condição humana, compreendemos que o homem é o único animal que vive existindo e que age para viver (CAPONI, 1997). No entanto, para existir é necessário cuidar do corpo, alimentar-se, higienizar-se, atender às demandas de nossa 
animalidade. Por estas razões, há que prevalecer no curso da existência uma dimensão voltada para a preservação da vida, ou seja, uma dimensão da qual não podemos nos apartar, pois subtende o "cuidado" essencial para a sobrevivência humana. Cuidar é atuar sobre o poder de existir, é possibilitar a libertação das capacidades de cada ser humano para viver. Nesta perspectiva, o cuidar é entendido como uma forma de promover a vida.

A doença e a as experiências de adoecimento são frequentemente vivenciadas como fenômenos que rompem com a continuidade da vida cotidiana, instalando-se como estranhamentos que, para serem superados, exigem cuidados especiais.

No entanto, o cuidado prestado ao ser humano, mesmo em situação de doença, não pode ser reduzido a uma meta a ser atingida, uma vez que integra a essência da vida. E como tal, tende a descartar falsos valores, determinando que somente seja agente de mudança àquele que ao cuidar transformar a si mesmo. Por este ângulo, o conhecimento sobre o cuidar não é sinônimo de informação, de adesão a uma teoria ou de engajamento a uma corrente filosófica, é antes uma experiência que dá sentido ao mundo.

Para Heidegger (1997), do ponto de vista existencial, o cuidado antecede toda atitude e situação do ser humano, o que significa dizer que o cuidado se manifesta em toda atitude e situação sendo, portanto, um fenômeno ontológico.

Em um outro momento de sua obra (HEIDEGGER, 1989), este autor nos diz que o cuidado é o solo em que se move toda existência humana, é a dimensão que nos permite experimentar o valor daquilo que nos cerca, do que tem importância e que definitivamente conta, ou seja, o valor intrínseco de cada coisa.

Adotando uma perspectiva que não se distancia dessa já apresentada, encontramos afirmações que indicam que o cuidado é parte da natureza e da constituição do ser humano, que é uma dimensão que revela, de maneira concreta, como é o ser humano (6). Neste 
sentido, o cuidar ressoa sobre a existência humana, tomando a forma de amor, da justa medida, da ternura vital, da cordialidade, da convivialidade e da compaixão radical. $\mathrm{O}$ cuidado significa uma relação de amorosidade com o mundo, com tudo aquilo que tem valor e interessa para nós, exigindo comprometimento e envolvimento, despertando preocupação e inquietação.

Assim, o cuidar é entendido como mais que um ato, é uma atitude que abrange atenção, zelo e desvelo. Ao conceber que o cuidar só se manifesta em plenitude nas relações que estabelecemos, é consequente a instalação de atitudes de preocupação, ocupação, responsabilização e envolvimento afetivo com o outro (BOFF, 1999).

Outras concepções semelhantes sobre o cuidar defendem que este é um processo básico que se estabelece entre as pessoas e que, enquanto tal, pode integrar conhecimentos humanísticos e científicos objetivando a satisfação de necessidades (CARVALHO; MELO; MULLER, 2002).

Nessa perspectiva, o cuidar e os cuidados vão assumindo os contornos de práticas profissionais. E as práticas de cuidar/cuidados, no tocante a Enfermagem, são magnificamente apresentados através da Teoria Transcultural do Cuidado (GEORGE; LEININGER, 1993). Considerando outras Teorias de Enfermagem, julgamos que esta se destaca por focalizar o cuidar e os cuidados como ocupação/ preocupação centrais da enfermagem e por postular que sempre existiram diferenças nas manifestações do cuidar e que estas estão associadas à cultura.

O cuidar está implícito em todas as atividades, processos e decisões que permeiam o cotidiano do enfermeiro, e que se manifesta nas habilidades tidas como ideais para assistir pessoas em circunstâncias de necessidade/sofrimento (9). Tais habilidades dizem respeito à capacidade de estabelecer empatia, de fornecer apoio, de demonstrar compaixão, de assumir comportamentos protetores, de prestar socorro, de educar e tantos outros comportamentos que estão em 
associação direta como as necessidades, problemas, valores e metas do indivíduo ou grupo que está necessitando de assistência (WOLFF et al, 1998).

Como fundamento da Enfermagem, o cuidar/cuidado se constitui como uma experiência que se estende para além do atendimento às necessidades básicas do ser humano no momento em que ele está fragilizado. Constitui-se como um compromisso com o cuidado existencial, ou seja, aquele que transpõe as demandas físicas para atingir o autocuidado, a autoestima, a autovalorização, a cidadania do outro e da própria pessoa que cuida (CALDAS, 2000).

Embora não tenhamos abordado todas as dimensões do cuidar, subjazem alguns pontos comuns que identificamos entre os autores trabalhados:

a) O cuidar/cuidados são essenciais e estendem-se a todas as dimensões da existência humana;

b) O cuidar é uma experiência que dá sentido a vida;

c) O cuidar é uma atitude ética, um compromisso, uma responsabilidade para consigo mesmo, para com os outros e para com o mundo;

d) O cuidar se manifesta nas relações que os homens estabelecem entre si e para consigo;

e) O cuidar/cuidados profissionais não podem ser restritos à execução de procedimentos técnicos.

Estes pontos são tomados como pressupostos que fundamentam a análise que empreendemos sobre os discursos dos moradores das residências terapêuticas. 


\section{Digressões acerca do Sofrimento Psíquico}

De início, uma pergunta fácil: o que significa o sofrimento? Respondê-la é empreendimento difícil, uma vez que o vocábulo é polissêmico. Em outras palavras, o sofrimento por ser vivenciado em diferentes circunstâncias da vida podendo assumir sentidos diversos.

Como afirmado anteriormente, as palavras adquirem diversas significações, de acordo com o contexto em que são utilizadas e/ou interpretadas. Caso tomemos isoladamente as palavras "sofrimento" e "psíquico", verificamos que a palavra sofrer é empregada no sentido de padecer, experimentar prejuízos, angustiar-se, amargurar-se e, ainda, resignar-se. Já o vocábulo psíquico designa o conjunto dos fenômenos ou de processos mentais conscientes ou inconscientes de um indivíduo ou de um grupo de indivíduos. Em intensidades diferentes tais processos estão presentes em todos nós e nos possibilitam reconhecer o nosso sofrimento e, o dos outros.

No entanto, há um núcleo comum a todos os sentidos e modos de sofrer (DANTAS; TOBLER, 2003). Se associarmos os sentidos acima explicitados e os aplicar ao sofrimento decorrente dos transtornos mentais, verificaremos que estamos a nos aproximar da dolorosa experiência de ser "diferente".

Verificamos que cada época - com seu específico contexto histórico-político - propõe uma "decomposição" do sofrimento psíquico objetivando compreendê-lo, classificá-lo e tratá-lo. O resultado destas operações vem escrevendo a história das relações que se estabelecem entre a sociedade, o doente e da doença mental. $\mathrm{Na}$ atualidade, essa não é mais uma história oculta, não sendo a este estudo recontá-la. Parece-nos suficiente reconhecer e não esquecer que as atitudes da sociedade para com o portador de sofrimento psíquico são predominantemente marcadas por estigmas e exclusões (CECCARELI, 2005). 
$\mathrm{Na}$ origem do estigma e dos comportamentos excludentes associados ao transtorno mental, parece repousar a concepção de “desvio" em relação a padrões de comportamento socialmente estabelecidos acerca do que seja o "normal". Também não podemos esquecer que as concepções e os sentidos apostos ao sofrimento e ao sofredor psíquico transitam incessantemente entre leigos e cientistas (REINALDO; ROCHA, 2002).

Feita essa observação, julgamos haver esclarecido que a perspectiva a partir da qual abordaremos o sofrimento psíquico não pode ser encontrada em dicionários técnicos. Trata-se de uma forma de refletir sobre as consequências, predominantemente sociais, decorrentes do transtorno mental, que não se restringem apenas à concepção da patologia psíquica, mas que se estendem a uma concepção de "existência-sofrimento". Para considerar o indivíduo como "existência-sofrimento" é necessário rever a clássica relação "problema-solução" proposta pelas ciências médicas para abordagem do transtorno mental. É necessário renunciar as soluções que perseguem a normalidade plenamente estabelecida.

Embora reconhecendo a existência das patologias psíquicas, compreendemos que os limites entre o que seja "normal" e "patológico" são imprecisos na exata medida que não existem demarcadores capazes de definir com exatidão as mudanças de um estado para o outro (GOBBO, 2004).

Mencionar os tratamentos propostos para os transtornos mentais é retornar a um passado, não tão longínquo, no qual a ausência de qualquer projeto constituiu-se como a base terapêutica das intervenções sobre o sofrimento psíquico.

Recuperando, de forma breve, a história da medicina, verificamos que, até o século XIX, os doentes permaneceram sendo exibidos na rua, nas feiras ou simplesmente recolhidos em asilos. Nada era feito no sentido de seu bem-estar ou de sua reabilitação, o que provavelmente decorria do fato de que até o final do século XIX não existia, 
em rigor, um saber sobre o sofrimento psíquico. A preocupação dos grandes psicopatólogos da época centrava-se sobre a sintomatologia. Os interesses centravam-se na classificação das manifestações psíquicas que escapavam às regras definidoras da normalidade.

O transcurso da história nos revela que foi necessário que as ideias humanistas instalassem um "clima" social propício a mudanças, e que Philippe Pinel (1745-1826) fosse influenciado por elas para que ocorresse o histórico episódio da libertação dos loucos (CORDEIRO, 2002).

Considerado um dos precursores da psiquiatria moderna, as reformas introduzidas por Pinel fizeram eco ao ideário da Revolução Francesa e Industrial. As ideias de Pinel podem ser traduzidas em termos de "liberdade" no hospício, "igualdade" entre sãos e doentes e "fraternidade", postas em ação através da filantropia e do esclarecimento. As propostas pinelianas inauguraram uma nova tradição para investigação e prática psiquiátricas: a articulação entre o saber e a técnica (FACCHINETTI, 2008).

Estabelecendo associações entre o passado e o presente, verificamos que, embora de modo diverso, ainda permanecemos lutando por algumas das causas que impulsionaram Pinel: "libertação" dos portadores de transtornos mentais, "tratamentos" menos agressivos, contatos amistosos com os doentes e a realização de "estudos" que nos possibilitem compreender as relações dos doentes com seus familiares.

No entanto, a grande ruptura epistemológica, no tocante ao sofrimento psíquico, concretizou-se através das ideias de Sigmund Freud (1856 - 1939). O pai da Psicanálise postula que o sujeito louco ou não - sempre que fala, fala do, e a partir de seu pathos ${ }^{7}$, que aqui se confunde com a trama discursiva que o constitui.

7 Segundo CANGUILHEM (1982, p. 106), o patológico implica em phatos, entendido como "sentimento direto e concreto de sofrimento e de importância, sentimento de vida contrariada". 
Depois de Freud, o indivíduo em sofrimento psíquico só pode ser pensado pela perspectiva da singularidade e da complexidade, devendo ser, enquanto tal, entendido na sua integralidade. Por conta dessa concepção, o conceito de sofrimento psíquico ultrapassa as barreiras da patologia, passando a ser apreendido como parte de uma existência em sofrimento.

$\mathrm{Na}$ contemporaneidade, para compreender o sofrimento psíquico é necessário que consideremos o indivíduo e seus entornos, ou seja, os aspectos biológicos, sociais e econômicos. É importante saber sobre os padrões de relacionamento com familiares e outras pessoas, a história do desenvolvimento emocional, físico, intelectual, sexual, dentre outros fatores.

Embora consideremos a singularidade dos indivíduos e, consequentemente, sua historicidade, verificamos que, em geral, a vida dos portadores de transtornos mentais é permeada por muitos sofrimentos e que estes são, frequentemente, consequências da própria doença e/ou das terapêuticas empreendidas. Os cuidados têm sido marcados por relações de subordinação tão severas em que o sujeito é "transformado em doente-objeto, não gente, não homem" (SOUZA; SCATENA, 2001), ou "improdutivos que raciocinam com outra lógica” (OLIVEIRA; COLVERO, 2001).

Uma mudança de paradigma emerge na saúde mental e caminha no sentido de delinear uma visão do portador de transtorno mental como sujeito, como cidadão respeitado em sua alteridade. Paulatinamente é abandonada a visão do ser doente como perigoso, anormal, que necessita ser excluído (GUIMARÃES et al, 2001).

Em conformidade com o novo paradigma, o prioritário é promover, em sentido amplo, a saúde do portador de transtorno mental e não apenas se preocupar com a patologia. O cuidar, assim entendido, inclui a redução dos fatores de risco previsíveis. Nesse sentido, o objetivo mais importante de qualquer intervenção é buscar o "melhor funcionamento" possível da pessoa, estando esclarecido que o ponto "ótimo" é absolutamente individual. 
Quando se fala acerca da prestação de cuidados ao portador de transtornos mentais é importante definir o que está sendo conceituado como saúde e doença, uma vez que a relação de cuidar emerge tanto na saúde quanto na doença. No tocante as manifestações severas de sofrimento psíquico, pode ser dito que estão em curso novas concepções sobre a "patologia psíquica", e que em paralelo estão sendo gestadas esperanças no que concerne às formas de tratamento.

\section{Digressões sobre as residências terapêuticas}

Para falar com propriedade acerca das residências terapêuticas é necessário lembrar, mesmo que sumariamente, alguns aspectos da trajetória da reforma que inspirou a atual política de assistência aos portadores de transtornos mentais em nosso país.

Lembramos que o processo denominado Reforma Psiquiátrica brasileira tem início em meados da década de 1970, através de denúncias que apontavam graves limitações terapêuticas e violências praticadas nas instituições psiquiátricas no atendimento de seus usuários.

Necessário recordar que, simultaneamente ocorreram outros movimentos reformistas, tais como os organizados em prol da reforma sanitária e em defesa dos direitos civis e humanos. Em decorrência da associação que se estabeleceu entre esses anseios, a sociedade passa a exigir novas formas de atendimento aos portadores de transtornos mentais (AMARANTE, 1995).

Ao longo do tempo, os anseios ganham a forma de propostas e estas vão se efetivando, nas décadas de 1990 e 2000, através de resoluções, portarias e leis emanadas do Ministério da Saúde. Destaque especial é dado à Lei 10.216 de 2001, que redirecionou o modelo assistencial brasileiro em saúde mental, prevendo cuidados 
integrais aos indivíduos internados por longos anos nos hospitais psiquiátricos e punição para a internação involuntária arbitrária ou desnecessária.

O contexto social e político viabilizam - mesmo com existência de focos de resistência - a implantação de novos serviços de atenção em saúde mental, tais como os Centros de Atenção Psicossocial (CAPS), os Hospitais-Dia e os Lares Abrigados (AMARANTE, 2001), posteriormente designados, mais apropriadamente, de serviços residenciais com função terapêutica (BRASIL, 2004).

O financiamento dos Serviços Residenciais Terapêuticos é tido como uma estratégia decisiva para consolidação da política de saúde mental, bem como para superação do modelo de atenção centrado no hospital psiquiátrico.

Sumarizado o contexto que viabilizou a instalação dos Serviços Residenciais Terapêuticos, também denominados de residências terapêuticas ou simplesmente moradias, podemos deles dizer que são casas localizadas no espaço urbano, que têm por objetivo primordial acolher e reintegrar portadores de transtornos mentais egressos de internação psiquiátrica de longa permanência, que não possuam suporte social e laços familiares ou que apresentem dificuldades de reintegração familiar (PREFEITURA..., 2007).

Dentre outros objetivos, as residências se propõem a resgatar a autonomia perdida após anos de internação e restituir a cidadania aos portadores de transtorno mental (BRASIL, 2005). Os direitos de morar e de circular nos espaços da cidade e da comunidade são, de fato, os mais fundamentais direitos que se reconstituem com a implantação, nos municípios, de Serviços Residenciais Terapêuticos.

Considerando os demais dispositivos substitutivos (NAPS, CAPS, Hospitais-Dia), as residências terapêuticas se destacam como locais nos quais os usuários podem se inserir de forma diferente daquela que é proposta nos serviços diários. Por não serem dotadas das características que tipificam os espaços terapêuticos, 
as residências apresentam-se como espaços nos quais se espera que o usuário possa experimentar e vivenciar redes de relações sociais mais amplas (BRASIL, 2000).

As residências terapêuticas não devem ingenuamente ser entendidas como ilhas paradisíacas para os portadores de transtornos mentais egressos de longos períodos de hospitalização. É necessário ter em mente que é no cotidiano, na trama das relações entrelaçadas ao sabor dos acontecimentos, que as dificuldades se apresentam. Se assim é para nós, homens e mulheres, mentalmente saudáveis e socialmente integrados, o que dizer do cotidiano que precisa ser (re)construído em termos espaciais, afetivos e sociais? Coragem pessoal e institucional - tem sido a arma para enfrentamento dos obstáculos concretos e das dificuldades subjetivas vivenciadas tanto pelos moradores quanto pelos profissionais de saúde mental que abraçaram a causa da reabilitação psicossocial.

Entendemos que as residências terapêuticas representam um dos maiores investimento no potencial dos portadores de transtornos mentais severos, na medida em que apostam na possibilidade de convivência urbana, na recuperação da autonomia e na devolução da cidadania.

No entanto, as residências terapêuticas já nos colocam diante de novos desafios: Como não serem socialmente identificadas como o "novo lugar do doente mental"? Como intervir no imaginário social? Como preparar a comunidade para estar em contato com aqueles que, desde há muito, são vistos como ameaças à integridade física ou moral? Como lidar com a violência suposta como inata?

No cerne das possíveis respostas para essas questões estão envolvidos os protagonistas da exclusão, ou seja, os portadores de transtornos mentais, os profissionais da saúde mental e a sociedade.

De modo breve, descreveremos as residências terapêuticas tendo por guia documentos oficiais. Devemos lembrar que, a inserção de um portador de transtorno mental em uma residência terapêutica é 
o início de longo processo de reabilitação que objetiva a progressiva inclusão social do morador.

O primeiro desafio a ser enfrentado na implantação de uma residência terapêutica é compor uma moradia igual as demais, ou seja, cada casa deve ser considerada como única, devendo respeitar as necessidades, gostos, hábitos e dinâmica de seus moradores (PREFEITURA..., 2007).

A casa não deve ser sinalizada por placas, timbres ou logomarcas, já que não pode se assemelhar a um serviço de saúde em sentido clássico, embora seja referenciada a um Centro de Atenção Psicossocial e opere junto à rede de atenção à saúde dentro da lógica do território (BRASIL, 2000).

O número de usuários pode variar desde um indivíduo até um pequeno grupo de, no máximo, oito pessoas. Estes, por sua vez, devem ser acomodados na proporção de até três por dormitório. A residência deve ser dotada da funcionalidade esperada em uma moradia comum, devendo, para tanto, ser equipada com todos os móveis e eletrodomésticos considerados básicos para proporcionar o conforto diário (BRASIL, 2000).

O suporte técnico prestado aos moradores das residências terapêuticas deve acontecer através dos serviços ofertados por uma equipe multidisciplinar - seja do CAPS de referência ou da atenção básica regida por uma filosofia e intervenções de caráter interdisciplinar.

As intervenções devem considerar a singularidade de cada um dos moradores e não apenas os projetos e as ações baseadas no coletivo. O acompanhamento a um morador deve prosseguir, mesmo que ele mude de endereço ou eventualmente necessite de hospitalização.

Intervenções de caráter social, educacional, ocupacional, comportamental e cognitivo devem ser postas em prática nas residências terapêuticas, visando a melhorar o desempenho funcional dos moradores e consequentemente facilitar a reabilitação psicossocial. 
Nos espaços da residência terapêutica, as atividades comuns relacionadas à vida diária, o funcionamento social, o relacionamento com familiares e amigos, o trabalho, a educação e o lazer devem ser exercitados, como parte do processo de reabilitação, na própria moradia ou em locais nos quais o comportamento é frequentemente realizado. A fala e a escuta dos moradores devem ser incentivadas, objetivando a melhor expressão de desejos, dúvidas, angústias e curiosidades. Do ponto de vista individual, respeitando limitações, os moradores devem ser orientados a lidar com dinheiro. Coletivamente devem participar da elaboração de listas de compras e da definição das prioridades da casa. Através dessas intervenções, busca-se responsabilizar o portador de transtornos mentais por suas atitudes, propiciando-lhe o entendimento das regras de convívio social (VIDAL; BANDEIRA; GONTIJO, 2008).

Não devemos esquecer que as pessoas que habitam uma residência terapêutica o fazem por apresentar necessidades especiais, caso contrário, estariam ocupando outros espaços/casas na cidade. No entanto, também devemos lembrar que a residência terapêutica pode servir como passagem para outro estágio da reaquisição da cidadania. Podemos pensá-la como um espaço no qual o morador faz o exercício de responsabilidade sobre suas atitudes, onde, aos poucos, reaprende a exercitar autonomia.

Associando essas ideias àquelas apresentadas pelos filósofos do cuidar, verificamos que as residências terapêuticas se constituem como espaços nos quais os indivíduos podem expressar sua complexidade. Complexidade que, mesmo marcada pelo sofrimento psíquico, se constitui como amálgama dos sentidos apostos à existência e ao estar no mundo. 


\section{Sobre os moradores das residências terapêuticas}

Para melhor compreender os sentidos atribuídos ao cuidar, investigamos algumas variáveis socioculturais, acompanhadas de dados da história clínica dos moradores das residências terapêuticas.

As variáveis investigadas dizem respeito ao sexo, idade, escolaridade, estado conjugal, paternidade/maternidade, religião e renda. Considerando o repertório das relações interpessoais, buscamos informações sobre a existência de vínculos familiares e se os moradores recebem visitas. Do ponto de vista clínico, identificamos o diagnóstico médico, o tempo de internação em hospital psiquiátrico e de moradia na residência terapêutica. As informações clínicas foram confrontadas com aquelas que constam nos prontuários dos CAPS que referenciam os moradores das residências. A junção dessas informações nos permitiu caracterizar os moradores das residências terapêuticas, como também vislumbrar adversidades já enfrentadas pelos mesmos.

Dos 21 moradores que constituíram a amostra, constatamos que a maioria $(57,8 \%)$ é do gênero masculino e que estão na faixa etária compreendida entre 42 a 51 anos. Destacamos que o mais jovem dos moradores tem 22 anos e o mais idoso 81 anos. No tocante à escolaridade, verificamos que $51,2 \%$ não foram alfabetizados. Daqueles que afirmaram ter frequentado a escola comprovamos que a maioria $(28,9 \%)$ não concluiu o ensino fundamental. O estado conjugal prevalente é o de solteiro $(75,5 \%)$. Junto às informações obtidas sobre o estado conjugal coletamos dados acerca da paternidade/maternidade, quando constatamos que a maioria $(88,9 \%)$ não possui filhos e que, entre os que afirmaram ser pais ou mães $(11,1 \%)$, o número oscila entre um e três filhos.

A maioria $(66,7 \%)$ referiu ter por religião o catolicismo, destacando-se que $20 \%$ não forneceram informações sobre seu credo religioso. 
No tocante à renda, contatamos que nenhum dos entrevistados trabalha, evidenciando a implícita relação que se estabelece entre doença mental e improdutividade. Estimulados a falar, verificamos que a maioria $(44,4 \%)$ dos moradores não soube fornecer informações acerca de sua renda. Dentre aqueles que afirmaram possuir renda, constatamos que a mesma decorre de pensões e de benefícios federais destinados às pessoas portadoras de deficiência que comprovem não ter meios de prover a própria subsistência e não possuam meios de ter a subsistência provida por sua família.

Essas pessoas recebem uma renda equivalente ao valor de 1 (um) salário mínimo, conforme regulamentam a Lei Orgânica da Assistência Social (Lei no ${ }^{\circ}$. 8.742, de 07 de dezembro de 1993) e o Decreto $n^{\circ}$. 1.744/95 (CREVANTI, 2006). Outra fonte de renda é o "Programa de Volta para Casa" (8,89\%) que objetiva contribuir para com o processo de inserção social das pessoas com longa história de internações em hospitais psiquiátricos, através do pagamento mensal de um auxílio-reabilitação. Os beneficiários são autônomos para sacar e movimentar mensalmente esses recursos (WITIUK; SILVA, 2003).

Investigando os vínculos familiares dos moradores, identificamos que $42,2 \%$ não mais possuem vínculos familiares, enquanto que um percentual equivalente a $28,9 \%$ foi encontrado entre os moradores que afirmaram possuir vínculos familiares e aqueles que não informaram. Entre os que afirmaram possuir vínculos este é predominantemente mantido com irmãos, seguido por pai, mãe, cunhado, esposa, tia, sobrinha e empregada da família.

Ao relacionarmos a existência de vínculos familiares ao processo de receber visitas, notamos que os dados são percentualmente idênticos, ou seja, 42,2\% afirmaram não receber visitas enquanto $28,9 \%$ afirmaram receber visitas. Verificamos que os visitantes citados são pessoas que não pertencem ao círculo familiar do morador das residências, sendo nomeados vizinhos da residência familiar e funcionários da rede assistencial. No curso da coleta destes dados, 
um acontecimento destaca-se: a expressa necessidade da visita dos familiares. Tal necessidade se manifestou por diversas vezes e tomou a forma da seguinte indagação:

\section{"Ei, minha mãe vem hoje?" $\left(\mathrm{E}_{18}\right)^{8}$}

Ao refletirmos sobre o conjunto das informações apresentadas, vislumbramos algumas das razões que justificam a presença dos entrevistados nas residências terapêuticas. Parece-nos oportuno destacar que, entre os fatores que determinam à recusa familiar em receber em casa o parente portador de transtorno mental, está o abandono assistencial do Estado. Tal situação traduz a ausência de programas assistenciais que assegurem às famílias a preservação do respeito aos seus direitos. Obedecendo a essa estranha lógica, a família apenas reproduz o processo de abandono e exclusão gerado pela ausência de políticas públicas e programas necessários ao atendimento das necessidades sociais desses cidadãos (VASCONCELOS, 1997).

Possivelmente, associa-se às razões anteriormente elencadas, o fato de a doença mental carrear para a família o estigma que tem acompanhado a pessoa portadora de transtornos mentais.

Destaca-se que - contraditoriamente aos objetivos do movimento de luta antimanicomial - a ameaça do abandono familiar tende a aumentar ao serem ressaltados apenas os aspectos negativos das estruturas asilares, pois desse modo é omitida a dimensão histórica das instituições ao assegurarem o "direito do usuário a local apropriado de refúgio nos períodos de sofrimento psíquico, e do direito da família à co-responsabilidade pública com o cuidado e tratamento de seus membros com problemas mentais" (VASCONCELOS, 1997).

Se os fatores implicados na origem do comportamento de abandono familiar parecem justificá-lo, o que dizer dos sentimentos da

8 Entenda-se: $\mathrm{E}_{18}$ corresponde ao número do entrevistado. 
pessoa que apresenta o transtorno mental? A condição de "doente", mesmo que mentalmente perturbado, parece produzir no indivíduo a sensação de ser um "fardo" para a família. Nossa suposição ganha o status de certeza comprovada através do discurso de um dos entrevistados:

"Não gosto de ser pesada prá ninguém... é por isso que estou aqui [residência terapêutica]..." $\left(\mathrm{E}_{12}\right)$.

Do ponto de vista clínico, verificamos que o diagnóstico mais frequente foi a esquizofrenia $(66,7 \%)$, com destaque para a esquizofrenia residual $(53,3 \%)$, predominante também em outros estudos (SILVA; BARROS, 2006). Segundo o CID-10, esta é um estado crônico da doença esquizofrênica, resultante da progressão de um quadro inicial para um quadro tardio, que se caracteriza pela presença persistente de sintomas negativos tais como: lentidão psicomotora, hipoatividade, embotamento afetivo, passividade e falta de iniciativa, pobreza da quantidade e do conteúdo do discurso, pouca comunicação não-verbal, falta de cuidados pessoais e desempenho social medíocre. Atentamos que esses sintomas não são forçosamente irreversíveis.

A informação sobre o diagnóstico dos moradores das residências se cruzada com a variável "renda", amplia a possibilidade de compreensão acerca da situação de dependência econômica dos portadores de transtorno mental, uma vez que a esquizofrenia é considerada uma doença incapacitante. Por essa razão, não surpreende o alto número de moradores que não trabalham e que dependem de benefícios governamentais.

Prosseguindo na investigação da história clínica, buscamos conhecer a idade em que ocorreram as primeiras internações em hospitais psiquiátricos. Verificamos, então, que a maioria dos moradores $(35,5 \%)$ não recordava com exatidão desse acontecimento, razão pela qual não conseguiam nos informar adequadamente. 
Dentre os que recordavam do momento de ruptura das relações familiares e sociais, a maioria (17,7\%) referiu ter entre 18 e 20 anos de idade. Este dado nos informa não apenas sobre a cronologia do momento no qual o transtorno mental se tornou agudo, como também nos permite vislumbrar o "estrago" social e, na maioria das vezes, existencial, decorrente das perdas advindas de uma hospitalização psiquiátrica: perda do emprego, da convivência familiar, das experiências amorosas, do círculo de amigos, de lazer e, lamentavelmente, da liberdade.

Privar alguém do seu habitat pode produzir uma "amnésia" acerca de suas origens, costumes e crenças; como também pode ter $\mathrm{o}$ sentido de "seqüestro" das experiências cotidianas.

Nos fragmentos de história de vida a que tivemos acesso, o intervalo de tempo vivido sob regime de hospitalização, quando contabilizado em termos de anos, ainda causa espanto: de 2 meses a 31 anos.

Entendemos que a problematização desta informação não reside na apresentação dos percentuais encontrados, mas nas considerações que podem ser feitas em torno do tempo em que esses sujeitos realmente "moraram" em hospitais psiquiátricos.

Atentamos que em nenhuma outra clínica se evidencia um tempo de hospitalização tão longo quanto o vivenciado por esses doentes. Um dos entrevistados, com a experiência resultante dos seus 31 anos de internação, comoveu-nos mediante a seguinte afirmativa:

"É o mesmo que ter nascido lá [hospital psiquiátrico]...” ( $\left.\mathrm{E}_{9}\right)$.

Entendemos que qualquer comentário acerca desta declaração não conseguirá exprimir os sentidos que podem ser apostos a experiência de nascer em um determinado local. Apenas podemos, a partir de nossa experiência pessoal, imaginar os efeitos do "nascer em um hospital psiquiátrico". 
Permanecendo no âmbito da coleta de informações relativas ao tempo, procuramos nos informar sobre o período de moradia dos entrevistados nas residências terapêuticas. Vale destacar que, quando comparado ao tempo das internações psiquiátricas, o intervalo de tempo de moradia nas residências terapêuticas é muito pequeno, ou seja, corresponde a, no máximo, 22 meses. Verificamos que a maioria $(48,9 \%)$ dos entrevistados está nas residências, há 11 meses, seguidos por 33,3\% que ali moram, há 22 meses e $17,8 \%$, há 20 meses. Para a devida apreciação desses dados devemos considerar que os serviços de residências terapêuticas são recentes em nossa cidade.

Esses dados, associados à observação assistemática que empreendemos sobre os moradores, seu comportamento e o ambiente, permitiram-nos inferir que, aparentemente, estão bem adaptados e que conseguem estabelecer interações satisfatórias entre eles e os cuidadores.

Entre as tentativas de restabelecimento de hábitos e a execução de tarefas cotidianas, um comportamento nos chamou atenção: alguns moradores circulam, por longos períodos, em volta da casa. Inferimos que este comportamento se assemelha à "ronda" que era estabelecida durante o tempo em que permaneciam no pátio do hospital psiquiátrico. Depreendemos que os comportamentos ali adquiridos persistem para muito além dos muros concretos do hospital, parecendo subsistir na forma de um "manicômio mental" que persiste e resiste às tentativas de reabilitação psicossocial.

Outra particularidade foi observada, tanto no discurso como no comportamento dos moradores, e diz respeito a não assimilação das residências como suas casas, espaço privilegiado da intimidade. Foram verbalizadas ideias que apontam para a persistência de representações das residências como "serviços que oferecem abrigo".

Assim finalizamos a caracterização dos moradores das residências terapêuticas, lembrando que o conhecimento de algumas 
variáveis, sociais ou clínicas, não nos diz quem é uma pessoa, no entanto, nos permite ter uma noção coletiva do contexto no qual foram gestados os discursos que nos permitiram ter acesso a concepções acerca do cuidar.

\section{Sobre o discurso e as percepções do cuidar elaboradas pelos moradores das residências terapêuticas}

A análise de conteúdo aplicada aos discursos nos possibilitou uma aproximação dos sentidos atribuídos ao cuidar/cuidado. Por esta razão, as categorias identificadas apenas plasmam as percepções e as concepções do cuidar em um determinado momento da existência dos moradores das residências terapêuticas. Necessário lembrar que os sentidos atribuídos ao cuidar não são estanques, modificam-se em conformidade com o ritmo e as experiências vivenciadas, no entanto, ao circularem livremente, possibilitam-nos apreendêlos e com eles aprender.

\section{Cuidar é ...}

Estimulados a falar, os entrevistados nos ofereceram um amplo repertório de associações que colocam o cuidar, ora em termos subjetivos, ora de forma objetiva, pragmática.

Tendo por base o discurso coletivo, aprendemos que o cuidar, em termos subjetivos, é dotado dos seguintes sentidos:

a) Experiência desconhecida e, enquanto tal, impossível de ser definida: eu num sei não, sei não $\left(E_{13}\right)$

b) Expressão de afeto e satisfação: cuidar de pessoas, dar carinho, dar afeto, dar atenção $\left(E_{18}\right)$. 
c) Reflexões existenciais: [cuidar] é viver a vida com uma risada ... é ver, ouvir e se calar $\left(E_{14}\right)$.

d) Relações familiares: cuidar é tomar conta de sua mãe, seu pai, seu filho $\left(E_{19}\right)$.

Já em termos objetivos, o cuidar é relatado através de tarefas executadas no cotidiano, tais como:

a) Trabalho inespecífico: cuidar é ... fazer as coisas... $\left(E_{12}\right)$.

b) Manutenção de hábitos higiênicos (ambientais e corporais): cuidar é lavar banheiro... ( $\left.E_{1}\right)$; cuidar é a pessoa dar banho... $\left(E_{10}\right)$.

c) Alimentação adequada: cuidar numa comida... $\left(E_{9}\right)$.

d) Adequação do comportamento: obedecer às instruções da casa... $\left(E_{4}\right)$.

e) Manutenção de hábitos saudáveis: cuidado no cigarro... $\left(E_{8}\right)$.

Refletindo sobre as categorias, identificamos, nos discursos, que o cuidar se manifesta nas relações que são estabelecidas com outras pessoas e com o mundo (WALDOW, 1998).

Pensado na dimensão que nomeamos de subjetiva, verificamos que ao trabalharmos com essa designação, estamos a adotar o sentido daquilo que se contrapõe ao que é objetivo. Ou seja, o subjetivo e, por deslizamento semântico, a subjetividade são referências ao que se passa no interior do indivíduo, o que podemos chamar de pessoal ou, de forma simplificada, de mundo interno. Já o objetivo e a objetividade são referências ao mundo real, objetivo, material. É o mundo da existência dos objetos, no qual, pragmaticamente, realizamos atos e ações. Essa dicotomia da experiência humana - aqui especificada em relação ao cuidar - não deve ser entendida como uma simplificação, mas como "momentos de estar no mundo" (BOCK, 1988). 
No plano subjetivo, destacamos os relatos nos quais o cuidar e os cuidados são verbalizados enquanto experiência desconhecida e, enquanto tal, impossível de ser definida. Se retomarmos aos pressupostos filosóficos, verificamos que experimentar o cuidar e os cuidados são experiências consideradas vitais e estruturantes. Como, então, interpretar relatos e experiências que são notoriamente marcados pela ausência de cuidados? De quando data a ausência de cuidados? Antecede o adoecimento ou é consequência deste? É marca indelével dos longos períodos de hospitalização? Para ter acesso a subjetividade é necessário cultivar a habilidade da observação. Este é um pressuposto decisivo para o sucesso ou o fracasso de uma relação de cuidar/cuidados, pois é a observação que nos dará subsídios para a construção deste processo. Responder a estas indagações exigiria um mergulho na subjetividade, consistiria na tentativa de descrever o que só pode ser revelado por quem viveu a experiência.

Mesmo considerando que, em parte, o "não saber" acerca do cuidar e dos cuidados pode resultar de limitações decorrentes do transtorno psíquico, é do conhecimento de todos que a ausência de projetos terapêuticos caracterizou os hospitais psiquiátricos que antecederam a reforma psiquiátrica. Com base em uma informação objetiva, inferimos que os entrevistados verbalizam o que viveram: a ausência de cuidados.

A dimensão objetiva do cuidar consiste na execução de atividades que se destinam ao atendimento de necessidades básicas e de adaptação às normas de convívio social. A não execução ou a violação dessas normas e/ou regras podem implicar em sansões que transitam entre a reprovação e segregação social. Em decorrência, o cuidado poder assumir sentidos que norteiam a execução de regras de boas maneiras até a realização de tarefas básicas da vida cotidiana. Manter os cuidados nomeados de objetivos é uma questão de sobrevivência. 


\section{Quem necessita de cuidados é...}

Em meio à conversa sobre o cuidar, estimulamos os moradores a verbalizarem quem, em suas opiniões, necessita de cuidados. Nessas ocasiões, foram verbalizados conteúdos que nos permitiram identificar as seguintes categorias:

a) Outras pessoas: gente de fora [da residência] (E9).

b) Os próprios usuários moradores: nós aqui [da residência], são os daqui (E12).

c) Não sabe informar: eu não sei ... (E2).

Mais uma vez é a filosofia que nos permite compreender os discursos coletados, uma vez que é ela que nos diz que todos, sem exceção, necessitamos de cuidados (CAPONI, 1997; SALES, 1997; HEIDEGGER, 1989).

Os entrevistados, ao identificarem as pessoas que acreditam necessitar de cuidados, permitem-nos inferir que não conseguem se imaginar como agentes de cuidados, embora reconheçam que outras pessoas, além deles mesmos, necessitam de cuidados.

\section{Cuidados anteriores e atualmente recebidos na residência terapêutica}

Para conhecer a perspectiva dos entrevistados acerca de suas experiências com o cuidar, solicitamos que falassem dos cuidados que receberam em tempo anterior à sua morada na residência, como também dos cuidados atualmente recebidos. Organizados os discursos, emergiram duas categorias: 


\section{Cuidados anteriores à residência terapêutica:}

Três subcategorias compõem esta categoria:

a) Nunca recebeu cuidados: de ninguém, não, não $\left(E_{13}\right)$.

b) Não sabe/ Não lembra se recebeu cuidados: eu não sei não $\left(E_{3}\right) ;$ num me lembro não $\left(E_{3}\right)$.

c) Cuidados recebidos de parentes: quem melhor cuidou de mim foi minha mãe... $\left(E_{21}\right)$.

A análise das duas primeiras subcategorias nos permite inferir que o cuidar e os cuidados são percebidos através de sua ausência, daquilo que faltou ou não pode ser recordado. Se lembrarmos que o cuidar e os cuidados nos constituem como pessoas, podemos vislumbrar o dano que a ausência de cuidados produziu nessas pessoas. Mais uma vez, somos convocados a pensar se a ausência de cuidados, ou da memória dos cuidados, está associada ao transtorno mental, ou se as experiências decorrentes do longo tempo de hospitalização apagaram antigas memórias do cuidar, restando-nos ainda a possibilidade de levantar a hipótese que o transtorno mental, associado às precárias condições de tratamento, tenha apagado memórias muito antigas do cuidar/cuidado.

$\mathrm{Na}$ terceira subcategoria, está expressa a força dos laços familiares nas memórias relativas ao cuidar. Nesse caso, nem o transtorno mental, nem a longa hospitalização apagaram as marcas dos cuidados recebidos.

\section{Cuidados atualmente recebidos na residência terapêutica:}

Foram identificadas as seguintes subcategorias:

1) Cuidados materiais: dinheiro, comida... $\left(E_{11}\right)$.

2) Cuidados genéricos: eu recebo cuidado aqui $(R T)\left(E_{4}\right)$. 
3) Recuperação da capacidade de autocuidado: quando é de manhã tomo banho, passo perfume $\left(E_{3}\right)$.

4) Atualmente não recebe cuidados: eu não recebo nada não $\left(E_{6}\right)$.

Os textos oficiais sobre as residências terapêuticas norteiam as inferências que empreendemos sobre as subcategorias identificadas. Evidencia-se que as subcategorias, "Cuidados materiais" e "Cuidados genéricos", são respostas diretas às necessidades básicas dos portadores de transtornos mentais egressos de longas internações psiquiátricas (PREFEITURA..., 2007).

Através da subcategoria "Recuperação da capacidade de auto-cuidado", inferimos que os entrevistados, ao executarem cotidianamente hábitos de higiene, tais como tomar banho, escovar os dentes, perfumar-se, dizem-nos do resgate da capacidade de autocuidarem-se, ou seja, de exercerem autonomia sobre seu próprio corpo. O desaparecimento de comportamentos simplórios - como os executados na higiene corporal -, no caso do transtorno mental, indica que o corpo pode deixar de ser um instrumento apto para o autocuidado em momentos de crise, o que nos leva a recordar que o cuidado é primeiro e fundamentalmente autocuidado (CAPONI, 1997).

Com relação à última subcategoria, denominada "Atualmente não recebe cuidados", tomamos conhecimento que alguns entrevistados afirmam não estarem recebendo cuidados nas residências terapêuticas. 


\section{Quando recebemos cuidados sentimos...}

Para realizar inferências sobre os discursos, recorremos ao pressuposto que afirma que o cuidar/cuidado só acontece com a transmissão de sentimentos (SILVA, et al, 2000). Verificamos que, embora cada indivíduo vivencie sensações e sentimentos de modo singular após receberem cuidados, foi possível identificar quatro categorias:

a) Sentimentos positivos: feliz, com amor, carinho $\left(E_{18}\right)$.

b) Sentimentos negativos: quando eu recebo cuidados eu fico, eu fico... fico estressado $\left(E_{5}\right)$.

c) Sentimentos indefinidos: às vezes eu me sinto bem e ao mesmo tempo não, porque não gosto de ser pesada prá ninguém ... eu nunca fui $\left(E_{17} \cdot\right)$

d) Não sabe/ Não sente nada ao receber cuidados: eu num sinto nada (E3).

Os "sentimentos positivos" prevalecem entre aqueles que foram relatados pelos entrevistados após receberem cuidados. Considerando que o cuidado tende a se manifestar quando são estabelecidas relações, os sentimentos de amor e cuidado - quando presentes - abrem caminho para um novo e profundo tipo de cuidado: o cuidado transpessoal. Uma relação de cuidado quando beneficia quem cuida e quem recebe cuidados estende-se para a natureza e o universo (SILVA, et. al., 2000).

Com relação aos "sentimentos negativos", as verbalizações nos permitem inferir que os cuidados estão repercutindo no indivíduo de forma inadequada, não suprindo necessidades, nem suscitando a real essência do que seja o cuidar. 
Ao analisarmos esses discursos, evidencia-se que não basta apenas conhecer as necessidades da pessoa de que cuidamos, é fundamental reconhecer seus sentimentos, uma vez que essa é uma das formas que conduz à prestação do cuidado real, daquele cuidado que diminui o sofrimento tanto em sua manifestação física quanto psíquica (GEORGE; LEININGER, 1993).

\section{Qualidades de um cuidador}

Os entrevistados nos apontaram qualidades que caracterizariam um bom cuidador. Nessa vertente dos discursos, identificamos três categorias:

a) Possuir condições (Intelectuais e materiais, Habilidades, Saúde): a pessoa deve ter inteligência... $\left(E_{7}\right)$; é ter saúde... ( $\left.E_{19}\right)$; de remédio, comprimido prá tomar... me dá lanche, almoço e janta... $\left(E_{8}\right)$.

b) Exercitar virtudes: deve ter humildade, né, humilde, manso de coração... (E $\left.E_{4}\right)$.

c) Não sabe explicar: eu num sei não, num sei explicar não $\left(E_{3}\right)$.

A primeira categoria, nomeada por "possuir condições", expressa as percepções dos moradores acerca de qualidades apontadas como essenciais para o cuidador, quais sejam: condições intelectuais e materiais, apresentar habilidades e ter saúde.

Ao evocarem o exercício de virtudes como qualidade do cuidador, os entrevistados voltam a fazer referências aos sentimentos positivos anteriormente discutidos. O cuidador deve experimentar os mesmos sentimentos vivenciados por eles ao receberem cuidados, ou seja, o cuidador deve ser espelho de ações que transmitam 
sentimentos positivos, tais como amor, carinho, atenção. É válido ressaltar que, para cuidar, é necessário aceitar a pessoa não somente como ela é, mas também como ela poderá vir a ser (CARVALHO; MELO; MULLER, 2002).

Por último, alguns dos entrevistados dizem não saber explicar que qualidades são importantes para o desempenho das tarefas do cuidar.

\section{Gostaríamos de receber os seguintes cuidados...}

Encerrando a entrevista, buscamos identificar quais os cuidados que os moradores das residências terapêuticas gostariam de receber. Como respostas a essa indagação obtivemos os resultados apresentados em três categorias:

a) Cuidados materiais: o dinheiro, tirar o dinheiro $\left(E_{1}\right)$.

b) Cuidados psíquicos: o amor da minha família $\left(E_{4}\right)$.

c) Não sabe/Não lembra: sei não, não tenho idéia não... ( $\left.E_{7}\right)$.

Consideramos esta como uma das questões mais marcantes em nosso estudo, cuja análise nos remete a uma específica demanda: de que cuidados necessitam os moradores das residências terapêuticas?

Quando declararam que gostariam de receber "cuidados materiais" e "cuidados psíquicos", os entrevistados verbalizaram anseios associados a necessidades e desejos pessoais que são concretamente identificados através da expressão da necessidade de "dinheiro" ou do desejo de "carinho de mãe".

A expressão de necessidades que podem ser supridas através do dinheiro nos revela que os entrevistados desejam bens materiais que 
não fazem parte de seu cotidiano, fato que, contextualizado em suas histórias de vida, é perfeitamente compreensível. Recordamo-nos das dificuldades materiais relatadas como inerentes à história familiar e aquelas vivenciadas em um contexto hospitalar caracterizado pela falta.

A segunda categoria intitulada "Cuidados psíquicos" é uma menção ao que os moradores desejam receber em termos afetivos. À semelhança de todos nós, os moradores das residências terapêuticas desejam receber carinho, amor e atenção daqueles que lhes são significativos.

Por último, deparamo-nos com aqueles discursos que indicam que o entrevistado "não sabe/não lembra" dos cuidados que gostaria de receber. Observamos que essas respostas foram frequentes em vários momentos das entrevistas, o que nos possibilita inferir que podem indicar limitações decorrentes do transtorno mental crônico.

\section{A título de considerações finais}

À guisa de encerramento, apresentamos pontuações que resultam da associação entre os resultados obtidos e as experiências vivenciadas na execução desta investigação. Tais pontuações objetivam conduzir o leitor primeiro a recuperar, de forma sumária, as ideias até aqui expostas e, segundo, possibilitar reflexões capazes de ampliar o entendimento acerca das percepções e dos sentidos atribuídos ao cuidar e aos cuidados pelos portadores de transtorno mental que, atualmente, têm por moradia as residências terapêuticas.

a) Investigar o cuidar e os cuidados recebidos por pessoas portadoras de transtornos mentais nos induz à reflexão sobre a nossa história particular e profissional de cuidados. 
b) Eleger o cuidar e os cuidados como objetos de investigação científica exige um mergulho na Filosofia e nas Teorias que exploram esse fenômeno em suas diversas formas de manifestações.

c) As Teorias consultadas apontam o cuidar e os cuidados como essenciais e extensivos a todas as dimensões da existência humana.

d) O cuidar só se manifesta quando são estabelecidos vínculos, conexões afetivas.

e) O cuidar não pode ser restrito à execução de procedimentos técnicos, pois é uma atitude ética, um compromisso assumido para conosco, para com os outros e para com o mundo.

f) O esclarecimento intelectual, advindo das teorizações sobre o cuidar, tende a ampliar horizontes e possibilitar a apreensão de muitos dos sentidos apostos ao cuidar.

g) A produção de sentidos e a percepção dos mesmos não é privilégio das pessoas ditas "normais", podendo e devendo ser investigadas entre todos aqueles que, estando doentes, encontram-se em situação de fragilidade.

h) O sofrimento psíquico decorrente dos transtornos mentais e dos tratamentos propostos para os mesmos é historicamente marcado pela ausência de cuidados, tanto sociais quanto profissionais.

i) Faz-se necessário divulgar que as residências terapêuticas são novos lócus para atendimento das necessidades dos portadores de transtornos mentais, em especial dos egressos dos hospitais psiquiátricos e, simultaneamente, poderosos recursos de reabilitação psicossocial. 
j) Uma residência, mesmo que revestida de características terapêuticas, é o local, por excelência, para viver a vida privada, para ordenar o cotidiano, para experimentar o aconchego da intimidade. É um lugar para experimentar a segurança.

k) As percepções verbalizadas e os sentidos atribuídos ao cuidar foram e são, constantemente, elaborados e reelaborados tendo por base a história de vida dos portadores de transtornos mentais.

l) Os moradores das residências, ao dividirem conosco suas percepções, permitiram-nos apreender que o cuidar se manifesta objetiva e subjetivamente. No plano subjetivo, destaca-se a falta produzida pela ausência de cuidados que, de tão profunda, chega a impedir a verbalização. Também foi privilegiado o sentido do cuidar que ganha a forma da expressão de afeto usualmente presente nas relações familiares. Ainda foram apreendidos sentidos indicativos que o cuidar conduz a reflexões sobre a existência. Em termos objetivos, foi-nos apontado que o cuidar se manifesta através da execução de tarefas que tipificam a vida cotidiana.

m) Os discursos indicam que a necessidade de cuidados é prioritariamente percebida como necessidade de outros.

n) Ao comparar os cuidados anteriormente recebidos àqueles atualmente prestados nas residências, os moradores indicam ter vivenciado experiências distintas. As experiências do cuidar anteriores à residência terapêutica são, mais uma vez, marcadas pela ausência concreta ou pela ausência de memórias relativas aos cuidados um dia recebidos. Já os cuidados atualmente recebidos são verbalizados em termos concretos ou como possibilidades de recuperação da capacidade de autocuidado. 
o) Os sentimentos experimentados pelos entrevistados, ao se sentirem cuidados, variam entre positivos, negativos e indefinidos. Também constatamos que é possível receber cuidados e não saber expressar o sentimento vivenciado. Maior estranhamento se instaura quando verificamos que é possível não sentir nada ao receber cuidados.

p) O cuidador descrito como dotado de qualidades ideais é aquele que demonstra possuir condições intelectuais, matérias, ter habilidades e humildade ao executar os cuidados demandados.

q) Os cuidados nunca recebidos são expressos através do desejo de posse de dinheiro e de amor, amor que é diretamente associado à família.

Em se considerando tudo que aqui se disse e lembrando que pensar é sinônimo de cuidar, é possível, sim, parafrasear-se Descartes, afirmando: "Cuido, logo existo".

\section{Referências}

AMARANTE, P. Loucos pela vida: a trajetória da reforma psiquiátrica no Brasil. Rio de janeiro: ENSP, 1995.

AMARANTE, P.; TORRE, E. H. G. Constituição de novas práticas no campo da Atenção Psicossocial: análise de dois projetos pioneiros na Reforma Psiquiátrica no Brasil. Saúde em Debate, v. 25, n. 58, p. 26-34, 2001.

BARDIN, L. Análise de Conteúdo. São Paulo: Edições, 2006.

BISON, R. A. P. A percepção do cuidar entre estudantes e profissionais de Enfermagem. 2003. 131f. Tese (Doutorado em Enfermagem). Ribeirão Preto: USP, 2003. 
BOCK, A. M. Psicologias: uma introdução ao estudo de psicologia. São Paulo: Saraiva, 1988.

BOFF, L. Saber cuidar: ética do humano - compaixão pela terra. Petrópolis: Vozes, 1999.

BRASIL. Portaria 106/2000 GM, de 11 fev. 2000. Institui os Serviços Residenciais Terapêuticos. Diário Oficial da República Federativa do Brasil, Poder Executivo. Brasília (DF), 21 fev. 2000.

. Ministério da Saúde. Residências Terapêuticas: o que são, para que servem. Brasília: Ministério da Saúde, 2004.

. Ministério da Saúde. Reforma Psiquiátrica e Política de Saúde Mental no Brasil. Documento apresentado à Conferência de Regional de Reforma dos Serviços de Saúde Mental: 15 anos depois de Caracas. Brasília: OPAS, 2005.

CALDAS, C. P. O sentido do ser cuidando de uma pessoa idosa que vivencia um processo demencial. 2000. Tese (Doutorado em enfermagem). Rio de Janeiro: UFRJ, 2000.

CAPONI, G. Concepção do cuidado e a especificidade da enfermagem geriátrica e gerontológica. Rev. Texto Contexto-Enferm, v. 6, n. 2, p. 51-56, 1997.

CARVALHO, E. C.; MELO, A. S; MULLER, M. O significado do cuidar para enfermeiros oncológicos. In: Brazilian Nursing Communication Symposium, 8, 2002, São Paulo. Proceedings online... São Paulo: EERP-SP. Disponível em: <http://www.proceedings.scielo.br/scielo. php?script=sci_arttext\&pid=MSC0000000052002000200016\&lng=en\&nr $\mathrm{m}=\mathrm{abn}>$. Acessado em: 11 mai. 2007. 
256 | Residências Terapêuticas

CECCARELLI, P. O Sofrimento Psíquico na Perspectiva da Psicopatologia Fundamental. Psicologia em Estudo, v. 10, n. 3, p. 471-477, 2005.

CORDEIRO, J.C.D. Manual de Psiquiatria Clínica. Lisboa: Fundação Calouste Gulbenkian, 2002.

CREVATIN, A. LOAS - Benefício Assistencial, 2006. Disponível em: $<$ www.institutoabrace.com.br/. Acessado em: 27 mai. 2009.

DANTAS, M. A.; TOBLER, V. L. O sofrimento psicológico é a pedra angular sobre a qual repousa a cultura de consumo, 2003. Disponível em: www.psicologia.com.pt./artigos/imprimir.php. Acessado em: 28 set. 2009.

FACCHINETTI, C. Philippe Pinel e os primórdios da medicina mental. Rev. latinoam. psicopatol. fundam., v. 11, n. 3, 2008. Disponível em: http://www.scielo.br/scielo.php?pid=S1415-47142008000300014\&script=sci_arttext. Acessado em: 04 jul. 2009.

GEORGE, J.B.; LEININGER, M. Teorias de Enfermagem: Porto Alegre, 1993.

GOBBO, A.F.F. Conhecimento do familiar da pessoa em sofrimento psíquico acerca da terapêutica medicamentosa a que a mesma está submetida. In: VIII Encontro de Pesquisadores em Saúde Mental. Ribeirão Preto: Maxi Color, 2004. p. 87.

GUIMARÃES, J., et al. Desinstitucionalização em Saúde Mental: considerações sobre o paradigma emergente. Saúde em Debate, v. 25, n. 58, p. 5-11, 2001.

HEIDEGGER, M. Ser e Tempo. 5º ed. Petrópolis: Vozes, 1997.

HEIDEGGER, M. Conferências e escritos filosóficos. São Paulo: Nova Cultural, 1989. 
OLIVEIRA, M.A.F.; COLVERO, L.A. A saúde mental no programa saúde da família. In: BRASIL. Ministério da Saúde. Manual de Enfermagem. Brasília: USP/IDS/MS, 2001.

PREFEITURA Municipal de Campina Grande. Disponível em: $<$ http:// www.portal.pmcg.pb.gov.br?page $=2067 \mathrm{a}=345>$. Acessado em: $04 \mathrm{fev}$. 2007.

REINALDO, M. A. S.; ROCHA, R. M. Visita Domiciliar de Enfermagem em Saúde Mental: idéias para hoje e amanhã. Rev Eletrôn Enferm, v. 4, n. 2, p. 36-41, 2002.

SALES, C. A. O cuidado de enfermagem: uma visão fenomenológica do ser leucêmico. 1997. 114f. Dissertação (Mestrado em Enfermagem). São Paulo: UNIFESP, 1997.

SILVA, J. P. L. et al. Perfil demográfico e socioeconômico da população de internos dos hospitais psiquiátricos do Rio de Janeiro. Cad. Saúde Pública, v. 15, n. 3, p. 505-511, 2000.

SILVA, J. P.; BARROS, S. O farmacodependente e suas percepções sobre a internação psiquiátrica. Ciênc. Cuid. Saúde, v. 5, n. 1, p. 32-40, 2006.

SOUZA, R. C.; SCATENA, M. C. M. Qualidade de vida de pessoas egressas de instituições psiquiátricas: o caso de ilhéus - BA. Saúde em Debate, v. 25, n. 58, p. 90-99, 2001.

VASCONCELOS, E. M. Saúde Mental e Serviço Social - O desafio da subjetividade e da insterdisciplinariedade. São Paulo: Cortez, 1997.

VIDAL, C. E. L.; BANDEIRA, M.; GONTIJO, E. D. Reforma psiquiátrica e serviços residenciais terapêuticos. J. bras. psiquiatr., v. 57, n. 1, p. 70-79, 2008 . 
258 | Residências Terapêuticas

WALDOW, V.R. Cuidado humano: o resgate necessário. Porto Alegre: Sagra Luzzatto, 1998.

WITIUK, I. L.; SILVA, R. C. R. Família do portador de transtorno mental: vítima o vilã? 2003. Disponível em: http://www.cpihts. com/2003_07_06/Ilda_lop.htm. Acessado em: 20 mai. 2009.

WOLFF, L. D. G. et al. Cuidar/cuidado: elementos e dimensões na perspectiva de pessoas internadas em hospital de ensino. Cogitare Enferm, v. 3, n. 1, p. 32-39, 1998. 


\title{
Resgatando vidas e redefinindo sonhos: experiência da Residência Terapêutica de João Pessoa - Paraíba
}

\author{
Ivoneide Lucena Pereira \\ Maria de Fátima Moura Feitosa \\ Cíntia Jaqueline Bezerra Galiza \\ Mércia Maria dos Santos
}

\section{A reforma psiquiátrica no mundo}

O advento da Reforma Psiquiátrica teve como nascedouro na Europa, especificamente Trieste, na Itália, primeiro país a aprovar uma lei antimanicomial, tendo como precursor Franco Basaglia, o qual estabeleceu um marco no movimento da desinstitucionalização da loucura.

Até o século XVIII, na Europa, os hospitais não possuíam a finalidade médica. Eram grandes instituições filantrópicas com o foco em abrigar os indivíduos considerados indesejáveis ou que não eram ativamente produtivos à sociedade: leprosos, sifilíticos, aleijados, mendigos, pobres e loucos. Tal população, na época, era marcada pela exclusão, consequência do poderio dos regimes absolutistas e da ampliação da reforma industrial. 
A criação de um hospital psiquiátrico, neste momento, histórico serviu como apaziguador das paisagens urbanas. Garantir a ordem pública e social implicou, em vários momentos, encaminhar essas pessoas consideradas indigentes para prisões e, mais à frente, para asilos construídos nos antigos leprosários.

Ainda vê-se hoje a relação existente entre os aparelhos policiais, como fortes apoiadores na manutenção da ordem da cidade, e continuam comuns as cenas de policiais transportando para hospitais psiquiátricos os usuários de drogas e/ou loucos.

Franco Basaglia conseguiu influenciar na criação de uma rede internacional de alternativas à Psiquiatria, junto com o movimento italiano com bases sociais para uma reforma com vistas à mudança de um modelo tradicional e crítica à instituição psiquiátrica asilar. O principal foco era a necessidade de redirecionamento da loucura, então reduzida à doença mental pela psiquiatria, tendo como demanda apenas a assistência médica e produzindo uma relação artificial entre a loucura e a sociedade, com base em qualidades morais, periculosidade e marginalidade que justificam a medicalização, a punição e a eliminação social da pessoa considerada doente mental (BARROS, 1994).

Surge, neste momento, o movimento da antipsiquiatria, capitaneado por David Cooper, Ronald Laing e Basaglia, propondo o fechamento dos hospitais psiquiátricos, por entendê-los como espaços de reclusão e exclusão.

Várias foram as tentativas de humanização da situação precária das instituições psiquiátricas. Todas elas fracassaram num ponto: a tentativa de redimensionar um aparelho equivocado por natureza, para o qual qualquer movimento de humanização ainda não o ressignificaria.

Consolida-se um crescente movimento de contestação do modelo com a paralela discussão sobre a urgência de um novo espaço para o adequado tratamento dos portadores de transtorno mental. 
As experiências de maior impacto nesse movimento de rediscussão sobre os novos tratamentos apresentaram vários modelos que incidiam, desde a clínica psiquiátrica propriamente dita, até mesmo uma nova localização espacial onde tal tratamento deveria ser oferecido.

Os desdobramentos mais expressivos desse processo de reorientação da assistência são vistos com as comunidades terapêuticas na Inglaterra e Estados Unidos; Psicoterapia Institucional, na França; Psiquiatria de Setor, na França; Psiquiatria Comunitária ou Preventiva, nos Estados Unidos; Antipsiquiatria, na Inglaterra; e Psiquiatria Democrática, na Itália.

Na década de 1970, o Parlamento Italiano aprova a Lei № 180 ou Lei Basaglia, que reorientava a assistência e implicava, estrategicamente, mudar o lugar da cidadania no tratamento dos transtornos mentais. A Lei 180 estruturou a Reforma Psiquiátrica Italiana, propôs a substituição do modelo asilar/hospitalar por um sistema de atenção psicossocial de base territorial (BARROS, 1994).

\section{A assistência em saúde mental no Brasil}

No Brasil, no mesmo período histórico, ocorriam discussões incipientes.

Antes disso, vários estados e municípios brasileiros anteciparam-se na criação de dispositivos legais de reorientação da assistência em saúde mental. Surgiu uma rede de movimentos sociais que acentuou os debates sobre os direitos humanos dos portadores de transtorno mental. Brotaram daí as associações de usuários e familiares, o movimento organizado da Luta Antimanicomial, experiências-piloto em serviços substitutivos entre outros.

Juntos, esses movimentos sociais construíram o Projeto de Lei no. 3.657/89, de autoria do deputado Paulo Delgado, que propôs a progressiva extinção dos hospitais psiquiátricos e sua substituição 
por outras modalidades de assistência. O projeto foi um grande marco na Reforma Psiquiátrica, possibilitando a ampliação das discussões políticas sobre a loucura.

O movimento da luta antimanicomial, na década de 1970, que se iniciou com o Movimento dos Trabalhadores em Saúde Mental (MTSM), ganhou um grande avanço com um caráter mais teórico e político, provocando transformações na saúde mental. Surgiram, dessa forma, serviços substitutivos em Saúde Mental, à proporção que novas leis foram sendo sancionadas.

Paulatinamente, foram sendo instalados os Serviços, chamados, no início, de Núcleo de Atenção Psicossocial (NAPS), mais adiante, de Centros de Atenção Psicossocial (CAPS), Hospital Dia, Hospital Noite, Leitos de Observação 24 Horas e leitos em hospitais gerais. O Sistema Único de Saúde (SUS) foi de fundamental importância por legislar sobre os direitos dos/as usuários/as, debatendo junto à sociedade os rumos das políticas públicas de saúde mental, concretizando-se a partir da Lei No 10.216, 06 de abril de 2001, que estabelece e regula as internações psiquiátricas.

Em paralelo ao surgimento desses serviços substitutivos, leitos em hospitais psiquiátricos iam sendo desativados, dando lugar a uma assistência psicossocial, que contrariamente ao sistema asilar, abria um leque de possibilidades de reabilitação aos/as portadores/ as de transtorno mental severo e/ou persistentes.

\section{A política de saúde mental na Paraíba}

No município de João Pessoa - Paraíba, o primeiro serviço substitutivo foi implantado no ano de 1998, o Hospital Dia, situado dentro do Complexo Psiquiátrico Colônia Juliano Moreira. Para tanto, foram desativados 30 leitos do citado Complexo. Este serviço existiu por nove anos; posteriormente, os usuários e equipe 
multiprofissional transferidos para os dois CAPS existentes geridos pelo município.

Entretanto, a construção da Política de Saúde Mental, sob a égide da Reforma Psiquiátrica, em João Pessoa, teve início no ano de 2005, com a ampliação e implementação de uma nova rede de serviços substitutivos tendo um avanço considerável. A partir desse período, o município abraçou a causa da Política de Saúde Mental como forte prática de atuação, na efetivação da reorientação da assistência no campo da saúde mental.

A partir do momento que a cidade passou a ter uma gestão que se pretende democrática e popular, esse foi o marco das mudanças estruturantes para a assistência de qualidade e humanizada à população.

A rede de cuidados em saúde mental passou a ser rediscutida com os/as profissionais da rede de atenção básica, o que possibilitou a aproximação da política de saúde mental aos trabalhadores/as de saúde da Estratégia Saúde da Família, tornando-se, assim, tema presente nas rodas de discussão e, consequentemente, nos planejamentos da rede de serviços do município de João Pessoa, nascendo, dessa forma, uma realidade palpável e viva.

O município dispunha, na década de 1990, de 01 CAPSad, sob gerência do estado e de 01 CAPS II, Gutenberg Botelho. No ano de 2006, implantou-se mais um CAPS tipo II. Em 2007, este CAPS passou a funcionar como CAPS tipo III, ou seja, funcionando 24 horas, de segunda a domingo, ficando o município com dois CAPS. No ano de 2007, implantou-se o primeiro serviço residencial terapêutico feminino. Em 2008, foi aberto um pronto atendimento em saúde mental e foi repactuada a forma de atendimento dos casos de urgência de saúde com a rede estadual da cidade, obtendo, através de diálogos coletivos, a re-estruturação da porta de entrada do/a usuário/a com transtorno mental, além de regular as internações psiquiátricas de todos os hospitais psiquiátricos existentes na cidade 
que atendem, muitas vezes, outros munícipes que não apenas o da capital. Ainda em 2008, foi inaugurado um CAPS Infanto-juvenil, atendendo à demanda não só de transtornos mentais graves e persistentes, mas também a crianças e adolescentes com problemáticas ligadas a álcool e outras drogas. Alem desse, ainda da rede estadual, existe um CAPSad, destinado a uma clientela de usuários/as de álcool e outras drogas.

Dessa forma, o cenário da rede de saúde mental conta com o atendimento de urgência, o Pronto Atendimento em Saúde Mental - PASM, no hospital geral do Complexo Hospitalar de Mangabeira, para atendimento dos portadores de transtornos mentais da região metropolitana; e, outro pronto-atendimento no hospital psiquiátrico no Sanatório Clifford, para cobertura dos demais municípios pactuados do estado da Paraíba. Essa iniciativa teve a finalidade de regular as internações psiquiátricas, haja vista, que proporciona uma possibilidade de avaliar nessas portas de entrada, pela equipe de plantão, a necessidade de internação, ou a permanência em leitos de observação até 72 horas.

Esse mecanismo proporcionou uma redução nas internações de longa permanência, pois permite um olhar integral para o/a usuário/a com transtorno mental, como também, a possibilidade de ampliação de oferta de serviços à disposição do mesmo. O PASM foi criado com a missão de ser retaguarda para as redes de saúde mental, em especial para equipamentos de maior complexidade como os CAPS, garantindo cobertura e comunicação médica nos horários em que os serviços de referências necessitarem, onde são auxiliados pelo SAMU no transporte para o pronto atendimento.

Além da ampliação de serviços de saúde mental na rede, a discussão foi saindo dos muros dos serviços e da Coordenação de Saúde Mental e invadindo as Equipes de Saúde da Família, de forma matriciada, utilizando ferramentas como: tecnologias "leves," rodas de conversas, construção de fluxos e encaminhamentos aos /as usuários/as, orientações por parte da equipe aos familiares, construção 
de projetos terapêuticos, leituras de textos e discussão dos mesmos, todo esse processo possibilitou a mudança do cenário na rede de serviços em saúde mental.

Assim o nosso Estado possui, atualmente, 223 municípios com 62 CAPS, sendo que 48, em 2009, estavam cadastrados no Ministério da Saúde e 14 restantes estavam em funcionamento, sem o cadastro, além de alguns outros serviços ambulatoriais gerais que atendem à demanda psiquiátrica.

Hoje, é possível perceber, depois dos últimos 04 anos de construção contínua, a mudança de práticas dos profissionais da saúde, dos gestores municipais e da Secretaria de Saúde e, principalmente, dos atores que estão mais envolvidos no campo da saúde mental. A reorientação do modelo assistencial permite contemplar áreas outrora relegadas ao descuido.

\section{A implantação da Residência Terapêutica na Capital}

No ano de 2005, foram listados, através da Central de Regulação, todos/as os/as usuários/as de longa permanência existentes nos hospitais psiquiátricos de João Pessoa; compostos por quatro instituições; em seguida, criou-se um questionário estruturado amplo e diversificado para ser aplicado aos/às usuários/as que se encontravam internos nos hospitais da cidade.

Essa equipe fez uma pesquisa de caráter qualitativo, onde se abordavam vários aspectos desses pacientes de longa permanência de ambos os sexos, como dados pessoais, história de vida, diagnóstico, atividades desenvolvidas dentro da instituição, vínculos existentes, entre outros. Essa pesquisa trouxe para a equipe reflexões profundas: percebeu-se nos moradores sentimentos de tristeza, medo, insegurança, desconfiança, falta de higiene, autocuidado comprometido, fantasias de que teriam que permanecer ali caso algum parente viesse lhe buscar; os cabelos das mulheres, em sua maioria, sempre 
curtos demais; presença de dermatites, poucas roupas para vestir e/ ou divisão de roupas com as outras; os banheiros abertos, sem porta de privacidade (característica de hospital psiquiátrico), muita dificuldade das internas em expressar opiniões, explicitar sua história de vida, descrever de que forma haviam sido internas ali.

Todos os/as entrevistados/as encontravam-se internos/as nos hospitais psiquiátricos de João Pessoa acima de 02 (dois) anos ininterruptos. Foram catalogados na pesquisa 92 (noventa e dois) destes, incluindo homens e mulheres, os quais, em sua maioria $98 \%$ abandonados por seus familiares.

Ao término das entrevistas, a equipe de saúde mental começou a buscar na comunidade um espaço físico adequado para acolher 07 (sete) ou 08 (oito) mulheres do hospital. Aqui se seguiram dificuldades múltiplas como: encontrar uma casa com tamanho suficiente, preconceito dos proprietários do imóvel para cederem sua casa para pessoas com transtornos mentais morarem - "loucos?" - era o que diziam. Passaram-se mais de 18 (dezoito) meses e a dificuldade continuava presente, quando se conseguia concluir o trâmite contratual da locação do imóvel os proprietários desistiam.

No ano de 2006, no mesmo período do ano anterior, a equipe de saúde mental voltou aos mesmos locais refazendo/reiterando/modificando/acrescentando novas informações de todos/as os/as internos/ as dos hospitais, utilizando como roteiro estruturado o mesmo questionário anterior, mas de forma mais objetiva, considerando a familiaridade com os entrevistados já conhecidos pela equipe.

Observou-se que alguns deles haviam morrido, outros/as estavam mais gordinhos/as e uma tristeza maior no semblante. Encontraram-se duas situações: uns/as usuários/as que não tiveram evolução nenhuma ao longo de 12 (doze) meses e outros/as que regrediram, sejam nos aspectos emocionais, quanto físicos/clínicos. Já no ano de 2007, em igual período, fez-se novo monitoramento e, em seguida, avaliação final para confirmar realmente as pessoas que iriam para a Residência Terapêutica Feminina. 
No mês de novembro de 2007, o prefeito da capital, a secretária de saúde do município, a diretora de atenção à saúde e representante da saúde mental foram ao hospital psiquiátrico convidar, oficialmente, as primeiras moradoras para fazer parte do novo serviço de saúde mental, registrando, assim, um marco histórico para João Pessoa, através dessas atitudes, ações e mudanças significativas para a área da Reforma Psiquiátrica e para a Luta Antimanicomial. A concretização desse ato manifesta uma nova modalidade de cuidado na Saúde Mental. Em outras palavras, solidifica-se um "dispositivo da área de saúde voltado para a reabilitação psicossocial e a promoção da saúde em seu caráter integral” (AMARANTE, 2008).

Segundo Oliveira (2003), para se dar início ao processo de implantação de um novo serviço de saúde, particularmente de saúde mental, e em especial um serviço residencial terapêutico, é interessante construir redes de apoio para dar suporte aos novos serviços que surjam. Logo, para poder abrir a Residência Terapêutica, a equipe de saúde mental da secretaria de saúde do Município e, também, alguns profissionais dos CAPS (psicólogas e assistentes sociais) existentes na época foram envolvidos.

Para fazer parte da equipe que iria cuidar das mulheres na RT, foi feita uma criteriosa escolha dessas cuidadoras, fizemos uma seleção para ocupar quatro vagas, onde através de entrevista realizada pela coordenação de saúde mental do municipal e com a participação de uma psicóloga do CAPS Gutenberg Botelho, deu-se a escolha das referidas cuidadoras.

A primeira Residência Terapêutica de João Pessoa foi inaugurada no dia 20 de Dezembro de 2007, com sete moradoras, oriundas do Complexo Hospitalar Juliano Moreira, onde essas moradoras, em sua maioria, passaram quase toda a sua vida ali morando, num longo processo de internação ininterrupta, com exceção de uma, com descendência marroquina, que contava com aproximadamente 03 anos de internação. 
Para escolher as primeiras candidatas, formou-se uma nova equipe multiprofissional para avaliar a partir dos dados coletados nos últimos três anos quais usuárias estariam mais aptas, num primeiro momento, para irem para a Residência Terapêutica.

A partir dessa catalogação, discutimos e traçamos estratégias de ações para início do processo de preparação dessas usuárias, através de encontros semanais. Dessa forma, em grupos sistemáticos com estas prováveis moradoras da RT, tentávamos uma desconstrução das identidades apostas, sem vínculo social, sem família, sem documentação, sem cidadania, com perspectivas arrancadas pela iatrogenia dos anos de moradia em manicômio. A intenção ia se dando, paulatinamente, até a mudança para a Residência Terapêutica. Após incessante procura, da casa em localização próxima ao CAPS III Gutenberg Botelho, referência da RT, a casa só foi encontrada em um bairro afastado do CAPS, no bairro de Mandacaru. Depois de grande luta para encontrar uma casa para esse tipo de clientela, conseguiu-se um espaço bastante confortável, espaçoso, de fácil localização, para acolher as egresssas que estavam aptas e dispostas para ali morarem, dando início ao processo de resgate de sua autonomia.

Mas a vida não é só ter uma casa para ficar admirando. Lá funcionava antes uma das unidades de saúde da família do Distrito IV, ficando assim a casa disponível para a RT, diversas reuniões aconteceram, todas voltadas à instalação da Residência Terapêutica naquele território, onde as moradoras seriam inclusas na rede de serviços de saúde, agora fazendo parte da área de cobertura de uma Equipe de Saúde da Família do Alto do Céu, diversas reuniões foram feitas com a equipe do Distrito Sanitário IV e com os/as profissionais da ESF, que iriam acompanhar as moradoras na RT, onde teriam o acompanhamento e visitas de uma agente comunitária de saúde e de toda a Equipe de Saúde da Família. Logo após a inauguração da RT, as mulheres foram a cada dia se inserindo e utilizando os serviços de saúde, assim como as atividades de lazer junto à comunidade. 
Ainda no processo de implementação, foram articulados vários segmentos da comunidade onde está inserida a RT, sugerindo-se e pleiteando as parcerias com os mesmos no processo de reabilitação das moradoras. As mulheres da RT conheceram antecipadamente a Unidade Saúde da Família próxima a casa, a praça existente, o grupo de idosos localizado no Centro de Referência do Cidadão, com mais de 40 idosos presentes dando-lhes as boas vindas; apresentação de música instrumental e, no final do encontro, dançaram forró e lancharam. Conheceram também o CAPS que iria ficar dando apoio biopsicossocial. Algumas reconheceram pessoas que lá trabalhavam que eram oriundas do hospital de onde elas estavam saindo e que há muito tempo não as viam. E tanto as moradoras quanto os profissionais se emocionaram muito. No decorrer do reconhecimento dos equipamentos sociais disponíveis na comunidade, elas se mostravam alegres e cantantes.

Não poderíamos deixar de colocar a importância da parceria com as Equipes de Saúde da Família de João Pessoa, hoje com 180 Equipes, onde as equipes do Alto do Céu (não pelo nome que trazem), mas pela responsabilidade, cuidado e acolhimento que tiveram com essas novas moradoras daquele território; tratando-as acima de tudo com responsabilidade e ética.

Para integrar a moradia, foram selecionadas 08 mulheres moradoras de hospitais psiquiátricos, da rede pública e privada, cujos critérios de escolha basearam-se no desejo manifesto, atrelado ao perfil de maior autonomia de cada uma, levando-se em consideração, também, os laços afetivos estreitados pelo tempo de convivência e afinidades. Oriundas de municípios como Pedra Lavrada, Pedras de Fogo, Caaporã e Campina Grande, do estado da Paraíba; Macau, no Rio Grande do Norte e do Marrocos, com idades variáveis entre 54 a 69 anos, sendo seis da Colônia Juliano Moreira e uma do Sanatório Clifford, abandonadas pela família.

Habitavam um pavilhão geriátrico onde era dispensada atenção diferenciada, dado o grau de comprometimento clínico; eram 
assistidas por duas psicólogas, que monitoravam essa assistência, inclusive atividades como confecção de tapetes, fuxico, almofadas, flores. Eram cuidadas dentro da lógica da cultura manicomial, a que eram submetidas, num viés único, sem possibilidades de uma identidade subjetiva; viviam delimitadas pelos muros patológicos, que as impediam de SER SUJEITO de sua própria vida. Sem perspectivas, obedientes ao sistema que lhes foi imposto pelos anos a fio de enclausuramento institucional. Eram amorfas em seu self, apáticas. Porém, o curioso é que eram meigas, mesmo com um olhar perdido no vazio de um porvir sem esperança. Experimentavam, na rotina, uma situação de abandono a que eram coagidas a aceitar pelo imperativo de não terem motivação nem autonomia para suas escolhas. Estavam sem projeto de vida, pois havia se perdido na desqualificação enquanto Sujeito, sem história, apenas lhes sobrava a doença como biografia.

No dia em que as moradoras se mudaram para a casa, alguns profissionais da Secretaria de Saúde, juntamente com as cuidadoras (pessoas contratadas pela prefeitura que organizam a casa e desenvolvem juntas as moradoras o resgate da autonomia e ressocialização), fizeram uma calorosa recepção, providenciaram lanche, mensagens escritas e música.

Na primeira noite, muitas delas não conseguiam dormir, não se sabe se era porque estavam muito eufóricas ou apenas estranhando o espaço físico, ou um misto de ambos. As mulheres escolhidas neste primeiro momento, já que existia um número maior de moradoras de instituições de longa permanência, mudaram-se para uma casa de verdade, onde cada uma teria sua própria cama, seu espaço, sua cozinha, sua sala, seu terraço, sua calçada, sua vida, cozinha, poderiam arrumar seus pertences. Enfim, fazer o que muitos cidadãos fazem todos os dias, e que, não se dão conta o quanto é valioso poder cuidar do próprio lar, da própria vida, do trabalho, do estudo, uma oportunidade única para resgatar a vida social, liberdade, respeito, dignidade, cidadania, autonomia, vida. Direitos fundamentais que regem a Constituição Federal de 1988. 
Nesse sentido, o Projeto Residencial Terapêutico vai muito além de uma simples morada, ele resgata a possibilidade de retomar uma vida que foi deixada para trás por causa das circunstâncias, de pessoas, ou outro motivo qualquer, corresponde a uma chance de poder se relacionar com outros indivíduos, ir à igreja, universidade, passear, praia, andar de ônibus, fazer novas amizades, expressando as novas frustrações, criando vínculos em outros espaços sociais. Os diversos parceiros, trabalhadores da saúde que compõem o corpo de trabalho da secretaria, incluindo os diversos serviços de saúde, mostram-se como atores atuantes na vida dessas pessoas, pois estes podem ajudá-las a melhorar ou piorar, dependendo da situação.

A residência terapêutica tem como diretriz a construção de um espaço aberto e democrático sob um suporte de proteção social e clínico, totalmente diferenciado de tudo que elas já tinham experimentado em detrimento do abandono familiar e do regime segregador em que viviam (BRASIL, 2007).

O maior desafio encontrado na desinstitucionalização, como dizem Delgado et al. (2001), está na "progressiva devolução à comunidade da responsabilidade em relação aos seus/as doentes e aos seus conflitos". Além desse desafio, deparamo-nos com a situação de ansiedade instalada nas moradoras, nas quais identificamos uma intensa dependência institucional, empobrecidas na sua autonomia e ainda com problemas clínicos.

A migração dessas usuárias para a Residência Terapêutica foi um trabalho paulatinamente delicado, tratando-se de todas as variáveis de ansiedade instalada. Nesse processo de desconstrução das sequelas psicológicas, do modelo asilar, de fato houve a necessidade de toda uma reestruturação de acordo com as singularidades de cada uma.

Observou-se que durante a preparação para a mudança, algumas usuárias ainda apresentavam alguma resistência, mesmo manifestando o desejo de ter uma casa. Essa dificuldade despertava um olhar 
mais apurado na representação da estigmatização a qual estavam submetidas. Embora o hospício, representante para nós como um modus vi vendi de insalubridade, ambiente totalmente segregador, estava no imaginário de cada uma como sendo um lugar protetor.

A simbologia desse significado incide na desumanização e alojamento, como se pertencessem a outro mundo. De acordo com Amarante (1995), a ideia do "duplo" torna-se o ponto de partida obrigatório, e esse "duplo" denuncia a função alienante, violenta, iatrogênica da psiquiatria, mas, fundamentalmente, coloca em questão sua função terapêutica.

Dito de outro modo, Basaglia (1985) refere os complexos de danos derivados de uma longa permanência coagida no hospital psiquiátrico, quando a instituição se baseia sobre princípios de autoritarismo e coerção. Tais princípios, donde surgem as regras sob as quais o doente deve submeter-se incondicionalmente, são expressões e determinam nele uma perda de interesse que, através de um processo de regressão e de restrição do EU, o induz a um vazio emocional.

No que tange ao financiamento, o Ministério da Saúde estabeleceu que os recursos de custeio e manutenção das residências terapêuticas são oriundos dos recursos das autorizações de internações (AIHS), dos 08 leitos ocupados por essas mulheres nos hospitais psiquiátricos, após desativação. Tal recurso é revertido para esse fim, desde que seja discutido na Comissão Intergestora Bipartite, instância de negociação dos interesses do estado e município, no ordenamento da política de saúde local (BRASIL, 2004). Além desses recursos, a cada implantação de uma RT, o Ministério repassa uma parcela única no valor de $\mathrm{R} \$ 10.000,00$ (dez mil reais), para fins de adequações na estrutura física da moradia e aquisição de mobiliário e utensílios.

Na implantação dessa moradia foi estabelecido um teto financeiro no valor de $\mathrm{R} \$$ 5.490,00 (cinco mil quatrocentos e noventa 
reais), faturado mensalmente, que expressa, a partir dos procedimentos realizados, o cuidado em saúde dispensado, além de alimentar o Sistema de Informações Ambulatorial - SIA/SUS. Esse recurso foi proveniente do fechamento dos 08 (oito) leitos do Complexo Hospitalar Juliano Moreira, hospital de natureza pública, sob gestão do município e gerência estadual. Salientamos que os custos das internações psiquiátricas dessas usuárias eram em média de R $\$$ $8.129,00$ (oito mil cento e vinte e nove reais) mensais.

É fundamental a observância de que os recursos que eram utilizados para o tratamento dessas mulheres, de forma segregada, eram bem maiores. E sob o ponto de vista de custo/benefício, houve uma redução nos custos da assistência de 33\% e ganhos incomensuráveis, uma vez que se livram do estigma de doentes mentais e passam a ter a possibilidade de viver com dignidade, pela reinserção na sociedade, e a perspectiva do resgate da autonomia, há muito perdida. Reafirmando, mais uma vez, que é possível quebrar paradigmas, instituindo um novo modelo assistencial, com ganhos para o/a usuário/a com sofrimento mental.

Ressaltamos que após alguns meses de abertura da RT, veio somar-se às sete moradoras iniciais uma outra, já com quadro de complicação clínica, e que tinha um forte desejo de morar numa casa. Algum tempo depois, foi acometida de recidiva do seu quadro, vindo a óbito no Hospital Universitário da Cidade. Foi providenciado o velório de forma digna, com a presença das demais moradoras, cuidadoras, profissionais do CAPS, do manicômio de onde procedia, pessoas da comunidade, da unidade de saúde da família de referência, como também o coordenador de saúde mental na ocasião. Esta moradora foi levada para RT em 12/02/08 e em 19/03 do mesmo ano, foi internada no hospital Edson Ramalho e, em seguida, sendo transferida para o HU-UFPB, onde veio á óbito no dia 03/04.

Avaliando o perfil das moradoras, assinala-se que pela própria história de vida, tinham pouca autonomia, eram um tanto dependentes, até porque na sua maioria são portadoras de doenças 
crônico-degenerativas, mas que no processo de reabilitação ao longo do cotidiano, começam a se estruturar em uma nova forma de vida, acontecendo significativas transformações em seu estar no mundo. Essas transformações se deram gradativamente, investindo-se na reeducação de hábitos na rotina de cada uma.

Em paralelo, foram incentivadas a desempenhar tarefas de acordo com interesses e disponibilidade peculiares, introduzindo-as na apropriação do espaço enquanto lar e nas atividades diárias as quais eram sempre estimuladas, como cuidar da casa, arrumar suas roupas e camas; pequenas tarefas que faziam a diferença para a reconquista de suas identidades. O interessante é que elas mesmas foram se apropriando e se organizando de forma que estes objetivos foram alcançados, avanços foram se estabelecendo e, ao final de um ano, já se consolidavam mudanças significativas em seus estilos de vida. Semanalmente eram realizadas rodas de diálogos, com todas, pertinentes aos objetivos propostos, com o CAPS sempre em contato dia a dia na assistência e manutenção da RT. A cada necessidade surgida, efetivavam-se reuniões com as cuidadoras na tentativa de solucionar as dificuldades e encaminhamentos para novas ações, como também, suporte efetivo.

\section{Em estado de considerações...}

Consideramos a RT um dos dispositivos da Reforma Psiquiátrica e que tem sido um dos desafios dentro dessa perspectiva no qual concerne à reabilitação psicossocial. Na primeira residência terapêutica do município de João Pessoa, chamada de "MINHA CASA", nome escolhido pelas próprias moradoras. A principal dificuldade verificada foi a idade avançada das mesmas, com pouca autonomia, em vista dos problemas clínicos apresentados. Todas com trinta a quarenta anos de afastamento sócio-familiar, institucionalizadas com a cristalização de hábitos estigmatizados e estereotipados. 
O desafio apresentado é um trabalho árduo, intensivo e sistemático e requer muita habilidade e capacitação dos que fazem as intervenções nesse processo de reabilitação. Todavia, vêm sendo construídas possibilidades de devolver a cidadania pautada no respeito pela singularidade de cada moradora, o direito de ser e morar em comunidade.

Por fim, diante do contexto sociocultural-histórico que está desenhado em nossa cidade, abrem-se portas num imenso leque de sentidos e possibilidades dadas às moradoras da residência e dos profissionais da saúde, para lidarem com algo novo, mas que se mostra possível e concretizado, a partir da mudança das teorias e práticas vivenciadas pelos múltiplos profissionais no desenrolar do funcionamento da residência terapêutica. É importante lembrar sempre que o dispositivo da Residência Terapêutica compreende fundamentalmente uma concretização de um movimento há vinte anos percorridos - a Reforma Psiquiátrica no Brasil - e que não pode ser esquecido; ao contrário, é preciso ter a atenção e clareza da concepção de que tipo de trabalho encontra-se em amplo desenvolvimento na prática, e da política que está sendo ampliada nos modos de morar dessas pessoas. Caso contrário, a casa pode ser um dispositivo manicomial, também, e não uma nova forma de estratégia para se trabalhar a inclusão das pessoas com sofrimento mental, levando-se em conta o projeto de vida de cada um/a no seu simples habitar. 
276 | Residências Terapêuticas

\section{Referências}

AMARANTE, Paulo. Loucos pela vida: a trajetória da reforma psiquiátrica no Brasil. Rio de Janeiro: INSP, 1995.

. O homem e a serpente: outras histórias para a loucura e a psi-

quiatria. Rio de Janeiro: INSP, 2008.

BASAGLIA, F. A instituição negada: relato de um hospital psiquiátrico. Rio de Janeiro: Graal, 1985.

BARROS, D. D. Jardins de Abel: desconstrução de manicômio de Trieste. São Paulo: EDUSP, 1994.

BRASIL. Ministério da Saúde. Departamento de Ações Programáticas Estratégicas. Residências terapêuticas: o que são, para que servem. Brasília: Ministério da Saúde, 2004. . Ministério da saúde. Departamento de ações programáticas estratégicas. Saúde Mental no SUS: acesso e mudança do modelo de atenção. Relatório de gestão de 2003-2006. Brasília: Ministério da Saúde, 2007.

DELGADO, P. G. G. et al. O Ministério da Saúde e a saúde mental no Brasil: panorama da última década. In: Conferência Nacional De Saúde Mental: Cuidar Sim, Excluir Não, 3., 2001, Brasília, Caderno de Textos. Brasília: Ministério da Saúde, 2001.

OLIVEIRA, A. G. B.; ALESSI, N. P. Cidadania: instrumento e finalidade do processo de trabalho da reforma psiquiátrica. Temas livres: ciência e saúde coletiva, v. 10, n. 1, p. 191-203, 2003. 


\title{
Construindo novos espaços: tecendo uma rede de apoio para os moradores das residências terapêuticas
}

\author{
Chirlaine Cristine Gonçalves \\ Andrea Abreu Calista \\ Ariedney Sâmylla de Souza Vasconcelos \\ Maria Cidney da Silva Soares \\ Stefan Yohansson Gonçalves
}

\section{Introdução}

Ao tentarmos enunciar saúde e doença, devemos estar cientes de que tais concepções possuem características próprias, de acordo com o contexto cultural dos diferentes grupos que compõem a sociedade. Além disso, saúde e doença não são valores abstratos ou condições estáticas. $\mathrm{O}$ entendimento sobre saúde depende da visão que se tem do ser humano e de sua relação com o ambiente, podendo ainda variar de sujeito para sujeito (FOUCAULT, 1995).

Deste modo, podemos afirmar que o conceito de saúde não está apenas restrito aos aspectos biológicos, mas às condições culturais, individuais, políticas, sociais, econômicas, históricas, tornando-se um conceito muito amplo e complexo. Assim, torna-se necessário ressignificar e reconceituar o que seja saúde, vê-la não apenas no campo científico, mas também como um movimento ideológico em aberto. 
Trovão (2003) relata que se torna limitado fazer saúde deixando de lado os aspectos psicológicos do indivíduo, e aponta a necessidade de que seja repensado não só o conceito de saúde, como também o de saúde mental, os quais estão completamente entrelaçados

A saúde mental, no Brasil, assim como no mundo é marcada pelo contexto asilar, onde a doença mental era tida como pressuposto para exclusão, reclusão e asilamento, que visava, sobretudo, a manter a segurança e a moral pública (GONÇALVES, SENA, 2001). Com isso, os portadores de transtornos mentais eram trancafiados e presos em manicômios sendo submetidos a tratamentos críticos e hostis e reclusos a qualquer contato social.

No final da década de 70, iniciam-se movimentos contra a forma de tratamento que as pessoas portadoras de sofrimento psíquico eram submetidas, sendo articulados pela organização do Movimento de Trabalhadores em Saúde Mental (MTSM), onde foram denunciadas corrupção, fraudes e negligência no âmbito da saúde mental. É nesse contexto que surge uma nova forma de ver e tratar a doença mental denominada de Reforma Psiquiátrica Brasileira, que tem seu marco com a crise da Divisão Nacional de Saúde Mental (DINSAN) (VECCHIA, 2006).

O DINSAN era um órgão do Ministério da Saúde responsável pela formulação das políticas de saúde do subsetor saúde mental. Os profissionais das quatro unidades da DINSAN deflagram uma greve em abril de 1978, após a demissão de 260 estagiários e profissionais (AMARANTE, 1996).

A crise foi anunciada a partir da denúncia realizada por estes profissionais, ao exporem as situações irregulares de alguns hospitais, trazendo a público a trágica situação existente. Tal fato repercutiu localmente, acabando por mobilizar profissionais de diversas unidades e recebendo apoio de diversos movimentos. 
Diante disso, a Reforma Psiquiátrica pode ser entendida como um processo político e ao mesmo tempo de âmbito social que tem ocorrido em territórios diversos, entre os quais, destacam-se as universidades, os serviços de saúde, nas associações de pessoas com transtornos mentais e de seus familiares, acoplados ao governo federal, estadual e municipal e que ocorre através da transformação de práticas, saberes, valores culturais e sociais (VECCHIA, 2006), assim, exige, além do esforço político e legal, uma reforma interior de cada indivíduo da sociedade para que padrões e preconceitos sejam revistos e haja uma ruptura dos valores de julgamento empregados aos portadores de transtornos mentais.

Embora a Reforma Psiquiátrica Brasileira tenha iniciado em conjunto com a Reforma Sanitária da década de 1970, aquela tem uma história própria que se baseou nas lutas sociais mundiais em favor ao combate das práticas violentas do modelo assistencial vigente, buscando concretizar os direitos dos cidadãos portadores de transtornos mentais (VECCHIA, 2006).

A evolução desse processo trouxe inovações em relação à assistência psiquiátrica instituindo novos modelos de atenção voltados para a reabilitação social através da ruptura das barreiras da desagregação familiar e social às quais os internos eram submetidos.

A criação de legislação específica para esse processo impulsionou a re-estruturação da atenção psiquiátrica e a trouxe para a pauta dos questionamentos sociais de estudantes e profissionais de saúde, governo, instituições privadas de atenção psiquiátrica, associações de portadores de transtornos mentais, de seus familiares e da sociedade em geral, pois todos se depararam com uma nova necessidade de adequação que já vinha ocorrendo de forma mais lenta.

A Lei Federal 10.216 entrou em vigor, em 2001, com o intuito de redirecionar a assistência em saúde mental, priorizando a oferta de tratamento em serviços de base comunitária, abordando acerca da proteção e dos direitos das pessoas com transtornos mentais (BRASIL, 2001). 
Em 2003, ocorreu a criação do programa do Ministério da Saúde denominado De Volta Para Casa que juntamente com a Lei 10.708 trouxe circunstâncias facilitadoras do processo de inserção social de pacientes com uma longa história de internação em instituição psiquiátrica, através de critérios específicos que devem ser seguidos e que institui um auxílio financeiro a esses pacientes como uma forma de facilitar sua autonomia, garantindo ainda a continuidade de acompanhamento profissional que auxilie na sua integração social (BRASIL, 2003; 2000a).

Nesse novo contexto, a rede de atenção à saúde mental adequada às novas demandas iniciou uma fase de expansão chegando a regiões de grande tradição hospitalar, onde pouco se conhecia acerca da assistência comunitária em saúde mental.

Com a proposta de uma re-estruturação dos hospitais psiquiátricos existentes, a Reforma Psiquiátrica trouxe novos impasses para a vida dos pacientes que se encontravam internados, pois muitos desses hospitais fugiam totalmente a nova proposta terapêtica e tiveram que se adequar às novas regras, sendo que grande parte faliu ou foi perdendo gradativamente seus leitos financiados pelo Sistema Único de Saúde (SUS).

Esse declínio do número de leitos, nos hospitais, ocorre devido ao Programa Nacional de Avaliação dos Serviços Hospitalares (PNASH/Psiquiatria) que tem por estratégia promover a redução dos leitos, conduzido a uma mudança assistencial, garantindo a construção simultânea de alternativas de atenção no modelo comunitário, trazendo à sociedade uma grande quantidade de pacientes que permaneceram por muitos anos sob regime de internação e que se encontravam dependentes de um sistema de assistência à saúde. Outro ponto a ser destacado é que muitos desses pacientes não tinham um ambiente familiar adequado para recebê-los e ainda havia aqueles que se recusavam a regressar para o "lar". Devido a todos os entraves advindos com o movimento da Reforma Psiquiátrica, uma necessidade surgiu: onde e como inserir os portadores de sofrimento psíquico no convívio social? 
Desde o ano 2000, entrou em vigor, em nosso país, a Portaria do Ministério da Saúde $n^{\circ}$. 106, que ressalta as necessidades dos portadores de transtorno mental, no que se refere à forma de atendimento, garantindo-lhes uma assistência integral e humanizada, re-estruturando a atenção em saúde mental com a redução dos leitos de hospitais psiquiátricos e a criação de um novo espaço para tratar o portador de sofrimento psíquico, denominado Serviço Residencial Terapêutico (SRT) (BRASIL, 2000a).

A proposta inicial das Residências Terapêuticas (RT) se constitui em uma moradia inserida preferencialmente na comunidade destinada àqueles pacientes egressos de internações prolongadas em hospitais psiquiátricos que não possuem uma base familiar para seu acolhimento. Esse sistema visa a integrar socialmente os indivíduos, permitindo a construção de sua autonomia através de um cotidiano que permite o morador, de acordo com suas necessidades e capacidades, estudar, trabalhar, realizar atividades domésticas e de lazer, enfim ter uma melhor qualidade de vida interagindo com a comunidade com a qual convive (BRASIL, 2004).

De acordo com a Portaria $n^{\circ} .106$, as RTs se constituem em uma proposta substitutiva aos serviços de hospitais psiquiátricos, com isso a cada transferência de paciente dos hospitais para a residência, serão reduzidas financeiramente as despesas de um leito no hospital que será destinado para o acompanhamento desse paciente no nível comunitário (BRASIL, 2002), a proposta de financiamento dos serviços substitutivos em saúde mental também encontra-se prevista no relatório final da III Conferência Nacional de Saúde Mental que define a necessidade de garantia de uma política de investimentos que reconheça a resolubilidade da rede de serviços de saúde mental substitutivos; a implementação de mecanismos ágeis e para o estabelecimento de convênios com o SUS para implantação, implementação e credenciamento de serviços substitutivos, entre eles os serviços residenciais terapêuticos buscando garantir: transferência de recursos de capital do Ministério da Saúde destinados aos investimentos iniciais de implantação e implementação; a criação de 
mecanismos que garantam a qualidade e eficácia das ações desses serviços; buscar formas de aprimorar os mecanismos de financiamento desses serviços, aumentando os valores até então propostos pelo SUS para os procedimentos desenvolvidos (BRASIL, 2000a).

As mudanças de financiamento ocasionadas podem ser observadas no Quadro 1, composta por dados do Ministério da Saúde referentes aos recursos destinados aos gastos de hospitais psiquiátricos e comparativamente aos dos serviços substitutivos de atenção a saúde mental, nos anos de 2002, 2003, 2004, 2005, 2006, 2007 e 2008.

Tabela 1. Proporção de recursos do SUS destinados aos Hospitais Psiquiátricos e aos Serviços Extra-Hospitalares nos anos de 2002 a 2008 (BRASIL, 2005).

\begin{tabular}{|c|c|c|c|}
\hline $\begin{array}{l}\text { Gastos Programas de } \\
\text { Saúde Mental }\end{array}$ & $\begin{array}{l}\text { Ações e programas } \\
\text { extra-hospitalares }\end{array}$ & $\begin{array}{c}\text { Ações e programas } \\
\text { hospitalares }\end{array}$ & Total \\
\hline 2002 & 153,31 & 465,98 & 619,29 \\
\hline $\begin{array}{l}\text { \% Incremento 2002- } \\
2003\end{array}$ & 47,42 & $-2,8$ & 9,63 \\
\hline 2003 & 226,00 & 452,93 & 678,94 \\
\hline $\begin{array}{l}\text { \% Incremento 2003- } \\
2004\end{array}$ & 27,14 & 2,78 & 10,89 \\
\hline 2004 & 287,35 & 465,51 & 752,85 \\
\hline $\begin{array}{l}\text { \% Incremento 2004- } \\
2005\end{array}$ & 41,34 & $-2,54$ & 14,21 \\
\hline 2005 & 406,13 & 453,68 & 859,81 \\
\hline $\begin{array}{l}\text { \% Incremento 2005- } \\
2006\end{array}$ & 33,45 & $-5,81$ & 12,74 \\
\hline 2006 & 541,99 & 427,32 & 969,31 \\
\hline $\begin{array}{l}\text { \% Incremento 2006- } \\
2007\end{array}$ & 40,31 & 2,94 & 23,84 \\
\hline 2007 & 760,47 & 439,90 & $1.200,37$ \\
\hline $\begin{array}{l}\text { \% Incremento } 2007- \\
2008\end{array}$ & 14,56 & 4,33 & 10,74 \\
\hline 2008 & 871,18 & 458,06 & $1.329,24$ \\
\hline
\end{tabular}


O Gráfico 1 apresenta a diminuição gradativa do número de leitos do SUS em hospitais psiquiátricos a partir do ano de 2002, demonstrando grande queda a partir da efetivação da Lei 10.216/01.

\begin{tabular}{|cc|}
\hline Ano & Leitos HP \\
\hline 2002 & 51.393 \\
2003 & 48.303 \\
2004 & 45.814 \\
2005 & 42.076 \\
2006 & 39.567 \\
2007 & 37.988 \\
2008 & 36.797 \\
$2009^{*}$ & 35.426 \\
\hline
\end{tabular}

*junho de 2009

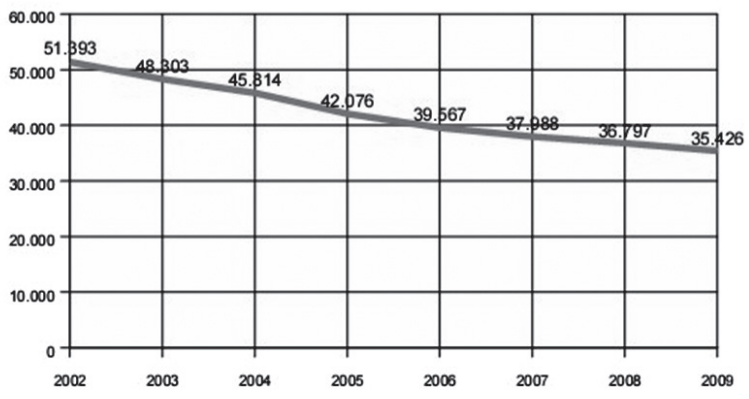

Fontes: Em 2002-2003, SIHySUS, Coordenação Geral de Saúde Mental e Coordenaçōes Estaduais. A partir de 2004, PRH/CNES e Coordenaçōes Estaduais.

Gráfico 1. Declínio no número de leitos psiquiátricos do SUS no período de 2002 a 2009 (BRASIL, 2005).

A evolução da implantação das RTs além de benefícios apontou também algumas necessidades, entre as quais, percebeu-se a necessidade de ampliar a abrangência de acesso dos portadores de transtornos mentais que não eram egressos de internações psiquiátricas de longa permanência ou que não possuíam suporte social e laços familiares que viabilizassem sua inserção social. E foi com o intuito de suprir essa necessidade que a III Conferência Nacional de Saúde Mental estabeleceu que as RTs passassem a não ser destinadas apenas para egressos de longas internações psiquiátricas, devendo ser incluídos além destes, todos os portadores de sofrimento mental, deficientes mentais e autistas que necessitassem deste tipo de assistência (BRASIL, 2002). 
Porém como a maioria dos pacientes beneficiados pelas residências terapêuticas permaneceu por muitos anos dependentes dos serviços psiquiátricos, há, por parte de alguns (a maioria) moradores, dificuldades para desfrutar da nova realidade, não conseguindo garantir inteiramente a sua autonomia, necessitando de um suporte profissional que pudesse auxiliar a travessia dessa fase de mudanças de forma amena e segura.

Em relação a esse fato, a Portaria 106/2000 que regulamenta a criação de RT também inclui a necessidade de garantir o direito dos moradores a uma assistência integral nos diversos níveis de complexidade através dos serviços do SUS, bem como estabelece, primeiramente, o acompanhamento assistencial dos moradores por uma equipe de saúde de serviços ambulatoriais especializados em saúde mental, que preferencialmente deve ser realizado pelo Centro de Atenção Psicossocial (CAPS) ou equipe de saúde da família, desde que supram as necessidades que os residentes apresentem. Essa equipe será responsável por dar assistência aos moradores, devendo ser composta por no mínimo um profissional médico e dois profissionais de nível médio. Cabe a esses profissionais o suporte interdisciplinar, integral e individualizado a cada morador, que deve ser acompanhado mesmo durante internações casuais ou mudança de endereço (BRASIL, 2001).

A equipe responsável por essa assistência necessita desenvolver ações integradas e intersetoriais nos campos da educação, cultura, habitação, assistência social, trabalho e lazer visando a proporcionar a melhoria da qualidade de vida para atingir o objetivo de garantia da integração social e autonomia dos moradores das RTs, o que se encontra previsto desde 2001, quando foi estabelecida, na III Conferência Nacional de Saúde Mental, a necessidade dessa intersetorialidade para o estabelecimento da política de saúde mental baseando-se nos princípios da Reforma Psiquiátrica (BRASIL, 2002). 
Mesmo com toda a sistematização e compromisso dos profissionais, notou-se, com o passar dos tempos, que muitos dos pacientes que possuíam uma estruturação familiar para retornarem, ao reingressarem no ambiente familiar e comunitário, passaram a apresentar dificuldades de manter-se estabilizados e assim muitos retornavam ao serviço residencial terapêutico em busca de acolhimento. A necessidade de mudanças tornou-se, então, evidente e uma alternativa foi lançada: a atuação da Equipe Itinerante.

\section{A equipe itinerante no processo de reinserção social}

O trabalho da Equipe Itinerante visa a uma proposta terapêutica diferenciada, onde o indivíduo é acompanhado diretamente no seu local de moradia de acordo com as peculiaridades de cada caso, a avaliar o processo de reinserção social do indivíduo, e a identificar os empecilhos para que este objetivo possa ser alcançado e as alternativas para reversão dessas dificuldades e/ou adaptação do usuário (LEITE; OLIVEIRA, 2006).

É formada por uma equipe multiprofissional, que trabalha nos serviços de saúde mental do município, esses profissionais têm a missão de trazer para a equipe problemas que acontecem nos serviços, bem como sugestões de ações que possam melhorar o serviço.

Durante todo o processo de desospitalização e de construção de uma rede extra-hospitalar, foram disponibilizados todos os instrumentos administrativos de gestão. O PSF, por ser um serviço mais antigo nas comunidades, foi de fundamental importância na busca de informações dos pacientes, e como apoio na construção dos serviços substitutivos.

Nesse contexto se faz necessário buscar alternativas junto às equipes de Saúde da Família, já que a Estratégia Saúde da Família (ESF) engloba tudo aquilo que possa levar a pessoa a ser mais feliz 
e produtiva, e se propõe a humanizar as práticas de saúde. Desse modo, fica clara a estreita relação existente entre a ESF e as novas práticas em saúde mental (BRASIL, 2000b).

Porém, para que essa articulação aconteça é de fundamental importância que o profissional esteja sensibilizado para a compreensão do modelo de organização familiar do portador de transtorno mental, bem como de seus valores, crenças e procedimentos, para que atue de modo a não julgar o que é melhor ou pior e sim oferecer elementos para a análise da situação (COLVERO; OLIVEIRA, 2001).

Portanto, esse profissional deve ter uma visão sistêmica e integral do indivíduo, família, comunidade, sendo este capaz de atuar com criatividade e senso crítico, mediante uma prática humanizada, competente e resolutiva, que busca envolver ações de promoção, proteção específica, assistencial e de reabilitação. Já que o objetivo da ESF é melhorar a saúde da população, mediante a construção de um modelo assistencial de atenção baseada na prevenção, promoção, proteção, diagnóstico precoce, tratamento e recuperação da saúde, em conformidade com os princípios do SUS e dirigido aos indivíduos, à família e à comunidade (GONÇALVES, 2005).

Vale também salientar que as ações de saúde mental fazem parte da atenção básica, de acordo com o que preconiza a Norma Operacional Básica do Sistema Único de Saúde (NOB/SUS - 96) e a Norma Operacional Básica da Assistência à Saúde (NOAS), como sendo responsabilidade mínima a ser consolidada pelo plano diretor de regionalização. Nesse contexto, essas ações devem ser incorporadas à rede diversificada de serviços realizados pela Estratégia Saúde da Família (PARAÍBA, 2001).

A atenção em saúde mental deve-se basear na comunidade e ao tempo em que a ESF tem apresentado claras tendências de expandir-se e ser adotado como modalidade dominante em todo país, impondo seu envolvimento no processo de discussão da reforma 
psiquiátrica, pois tem a família e a comunidade como unidade de trabalho. Além disso, segundo estimativas, uma em quatro famílias tem pelo menos um membro que apresenta atualmente um transtorno mental ou comportamental (OMS, 2001).

Contudo, a prática comunitária em saúde mental proporciona que a luta pela reversão da exclusão seja levada às bases da sociedade, para que esta seja potencializada. Com esse trabalho junto à atenção básica, o questionamento acerca do conceito de doença mental passa a ser exercido na prática diária, e as ações podem, inclusive, representar uma mudança no modo como são tratados os transtornos mentais e de comportamento, levando a comunidade a redefinir seus conceitos sobre o que é a doença mental. Além disso, a atenção baseada na comunidade tem melhor efeito sobre o resultado e a qualidade de vida das pessoas com transtornos mentais crônicos do que o tratamento asilar. Essa transferência de usuários de hospitais para a comunidade, além de demonstrar uma melhoria na relação custos e benefícios referentes à saúde mental, respeita os direitos humanos (OMS, 2001).

Nessa perspectiva da saúde mental na atenção básica e com a implantação da Estratégia Saúde da Família, podemos visualizar um caminho que poderá dar uma direção para a construção de um processo de emancipação daqueles que se encontram em sofrimento psíquico, uma vez que o programa, como já mencionado, visa a dar uma assistência integral a toda comunidade sob sua responsabilidade. Ademais, estamos passando por um processo de desinstitucionalização, no qual a Atenção Básica é integrada a outras políticas de substituição dos serviços de saúde, e a Estratégia Saúde da Família é fundamental nesse processo de construção, pois conhece sua comunidade e trabalha a integralidade do usuário, sendo, na maioria das vezes, a primeira escolha dos portadores de distúrbios mentais e de comportamentos (GONÇALVES, 2005).

A ESF surgiu como uma ajuda mútua aos serviços substitutivos de saúde mental, e percebe-se várias semelhanças entre esses serviços 
e a ESF, o que permite uma excelência no cuidado à comunidade e principalmente no que diz respeito ao sofredor psíquico.

Portanto, com a saúde mental sendo incorporada a atenção básica, torna-se mais fácil reverter a situação em que o portador de transtorno mental se encontra, pois esta, às vezes, requer apenas a conscientização da família e da vizinhança, ou uma alternativa de ocupação com geração de renda, mas não há como definir ou configurar previamente as intervenções necessárias por parte dos profissionais da equipe, pois sempre será necessária uma avaliação minuciosa da situação para que a reinserção social seja realmente eficaz.

Além disso, uma pesquisa realizada, em 2005, mostrou que já existe uma preocupação dos profissionais da atenção básica, que assumem mesmo uma responsabilidade, quando intetam buscar soluções alternativas para o tratamento dos transtornos mentais e comportamentais. Isto é visível na bem sucedida experiência relacionada à estratégia do atendimento aos portadores de transtorno mental do bairro Pedregal, na Unidade Básica de Saúde da Família (UBSF) Adalberto César, localizada na Rua Nilton Paiva Fernandes $\mathrm{S} / \mathrm{N}$, localizada na cidade de Campina Grande, Paraíba. Este município está situado na Zona Centro-Oriental da Paraíba, no Planalto da Borborema, a $120 \mathrm{~km}$ da capital, equidistante em relação aos principais centros do Nordeste (GONÇALVES, 2005).

As usuárias participam do Grupo de Saúde Mental, há mais de quatro anos, e após essa participação, não houve nenhum registro de internação psiquiátrica; quatro delas não fazem mais uso de medicação; três diminuíram o uso; três utilizam esporadicamente e apenas uma continua fazendo uso de psicotrópicos, porém em doses inferiores às administradas anteriormente à entrada no grupo.

Todas as prescrições de psicotrópicos foram revistas, por meio de consultas com psiquiatras do SUS e marcadas através da Unidade Básica Saúde da Família Adalberto César, sendo cada esquema terapêutico planejado e estruturado individualmente, visando à solução 
dos problemas clínicos de cada usuária. Além do tratamento farmacológico, foram introduzidas as psicoterapias, como relaxamento, terapia de apoio e reabilitações psicossociais. Essas estratégias variam segundo a necessidade de cada usuária e têm como objetivo a promoção da saúde do Grupo de Saúde Mental (GONÇALVES, 2005).

É importante enfatizar que, mesmo sendo escassos esses serviços, a realidade começa a mudar uma vez que o movimento da Reforma Psiquiátrica já se encontra atuante em Campina Grande.

Tudo isso nos mostra que é possível trabalhar saúde mental e como é resolutivo. A implantação do Grupo de Saúde Mental na ESF do bairro Pedregal, mostra isso. É muito gratificante perceber que alguns municípios começam a se preocupar em descobrir quem são esses portadores de sofrimento psíquico, qual a origem familiar deles, criar serviços extra-hospitalares para restabelecer seus laços vitais, para que sua cidadania, seu direito de escolha e seu convívio familiar sejam devolvidos.

Além da Equipe Itinerante e das ESFs, as Residências Terapêuticas necessitam de apoio para lidar com os usuários em crise, com isso se faz necessário ter como base um local de referência e neste cenário entra a Unidade de Emergência Psiquiátrica.

\section{A Unidade de Emergência Psiquiátrica como suporte}

No Brasil, a Lei no 10.216, de 6 de abril de 2001, - que dispõe sobre a proteção e os direitos dos usuários de saúde mental e a mudança do seu modelo de assistência; que dispõe sobre a extinção progressiva sobre os manicômios e sua substituição por outros recursos assistenciais; e regulamenta a internação psiquiátrica compulsória; ou seja, propõe que a assistência à saúde mental, no Brasil, não mais se baseia nos hospitais psiquiátricos, mas em outras estruturas não manicomiais. Também nos garante, através do seu artigo $4^{\circ}$ e $\$ 1^{\circ}$, 
que o tratamento visará, como finalidade permanente, a reinserção social do paciente em seu meio (GONÇALVES; SENA, 2001). Exposto isso, a Emergência Psiquiátrica de Campina Grande, antes conhecida como Unidade de Referência em Saúde Mental, teve sua criação no ano de 2005, durante o processo de Reforma Psiquiátrica que ocorria e continua ocorrendo em todo o Brasil.

O Ministério da Saúde visa com esta Reforma à extinção do modelo manicomial vigente e a reinserção social do indivíduo portador de transtorno mental. No município de Campina Grande, interior do Estado da Paraíba, localizado na região Nordeste do Brasil, ocorreu um processo de intervenção federal na instituição psiquiátrica denominada o Instituto Campinense de Neuropsiquiatria e Reabilitação Funcional (ICANERF), popularmente conhecido como Hospício João Ribeiro. Dos 176 internos, alguns retornaram para seus lares; outros foram encaminhados para os Serviços de Residências Terapêuticas (SRT's); outros, ainda, ficaram sob responsabilidade de seu município de origem; e, alguns outros, considerados moradores do hospital, pelos longos anos de internação, foram encaminhados, ao término da intervenção, para a Unidade de Referência em Saúde Mental para tratamento e acompanhamento dos casos de surto/crise psiquiátricos destes usuários, vista a cronicidade e severidade do transtorno que os acometiam. Contudo, ao longo de dois anos, a estrutura de funcionamento foi gradativamente se modificando para se adequar às diretrizes preconizadas pelo Ministério da Saúde no tocante ao funcionamento de emergências psiquiátricas e, o ponto auge desta metamorfose foi a mudança de espaço físico da então Unidade de Referência em Saúde Mental para o Hospital Geral e Maternidade Dr. Edgley, nesta cidade, e do nome fantasia da Instituição para Emergência Psiquiátrica, especificando claramente o tipo de atendimento por esta prestado.

A Emergência Psiquiátrica de Campina Grande atende a usuários do município de Campina Grande em casos de crise ou surto psiquiátrico, seus atendimentos são prestados diuturnamente, 
funcionando 24 horas por dia. Dispõe, atualmente, de 13 leitos para internações de adultos (07 masculinos e 06 femininos).

O papel da equipe multidisciplinar hoje é o de agente terapêutico, e a base dessa terapia é o relacionamento com o paciente e a compreensão do seu comportamento. O objetivo do "cuidador" não é o diagnóstico clínico ou a intervenção medicamentosa, mas sim o compromisso com a qualidade de vida do portador de distúrbio mental. Nesse sentido, a equipe multidisciplinar deve ser preparada para atuar em novos modelos de atenção, assumindo novas tarefas e adequando-se às mudanças advindas da atual política de saúde mental vigente no país. Os cuidados oferecidos devem respeitar e acolher a diferença do usuário; o qual deve ser percebido como um sujeito humano e não como um sintoma a ser debelado. Os profissionais devem estar cada vez mais atuantes e conscientes de seu novo papel e terem condição de colocar, em práticas, alternativas de atenção ao doente, para que mantenham o exercício de sua autonomia, cidadania e reabilitação; tornando o tratamento mais prazeroso, objetivando a transformação das relações da sociedade com essas pessoas (BRASIL, 2001).

No que concerne aos recursos humanos, a equipe que atua na Emergência Psiquiátrica é multidisciplinar, formada por 07(sete) médicos clínicos gerais e 01(um) médico psiquiatra, 06 (seis) enfermeiros, 18 (dezoito) profissionais de nível médio-técnico (técnicos e auxiliares de enfermagem), 01 (um) assistente social, 01 (um) farmacêutico, 01(um) psicólogo e 14 (quatorze) profissionais de nível elementar (Agentes de Serviços Gerais, Recepcionistas, Porteiros).

No que diz respeito à relação entre a Emergência Psiquiátrica e as residências terapêuticas, é oportuno ressaltar que, durante a crise, esse usuário que está inserido na EP tem todo o suporte na Emergência, seja indo até o serviço ou caso seja necessário, a equipe da Emergência vai até a residência. A EP em contrapartida é a referência para a continuidade do tratamento, visando à reinserção social do usuário. 
Sendo considerada Emergência Psiquiátrica, qualquer alteração de comportamento que não pode passar por um manejo rápido e adequado dos serviços de saúde, sociais ou judiciários que existem na comunidade. Logo esta definição leva-nos a sugerir que as Emergências Psiquiátricas não são consideradas funções exclusivas de determinados serviços de atenção à saúde, pois muitas vezes requerem tratamentos especializados encontrados em serviços específicos, tais como, na unidade de Emergência Psiquiátrica (LEITE; OLIVEIRA, 2006).

Nesse contexto, a Unidade de Emergência Psiquiátrica como preconiza o Ministério da Saúde deve funcionar dentro de um Hospital Geral, contando com uma equipe multiprofissional que lida com os usuários em surto, ou seja, com os casos de emergência.

Com o passar dos anos, os serviços de Emergência Psiquiátrica foram influenciados por mudanças ocorridas nas políticas de saúde mental, como a desinstitucionalização dos manicômios, e o desenvolvimento de serviços psiquiátricos extra-hospitalares, como os CAPS, as Residências Terapêuticas. Essas mudanças ocasionaram a reestruturação das Emergências Psiquiátricas fazendo com que essas se adaptassem as novas demandas e ampliassem suas funções, proporcionando suporte psicossocial, e também a triar os casos de internação intervindos nos quadros agudos, estabilizando ou iniciando o tratamento definitivo em um paciente em crise (DEL-BEM et al, 1999).

Porém independente da necessidade das RTs, torna-se necessário refletir sobre essas pessoas que vivem, há tanto tempo, expulsas da sociedade, sem cidadania, sem direito à escolha, sem identidade; impulsiona-nos a ter a certeza de que podemos trabalhar e mudar a forma como a sociedade vê e trata os portadores de transtorno mental; mostra-nos que é essencial redefinirmos a compreensão dos tratamentos psiquiátricos, lutando contra os medos que a sociedade incutiu na nossa mente. $\mathrm{E}$, finalmente, leva-nos a acreditar que louco é o mundo e loucura é achar que existe normalidade. 


\section{Referências}

AMARANTE, P. O homem e a serpente: outras histórias para loucura e a psiquiatria. Rio de Janeiro: FIOCRUZ, 1996.

BRASIL. Ministério da Saúde. Reforma psiquiátrica e política de saúde mental no Brasil. Documento apresentado à Conferência Regional de Reforma dos Serviços de Saúde Mental: 15 anos depois de Caracas. Brasília: OPAS, 2005.

.. Ministério da Saúde. Residências Terapêuticas: o que são, para que servem? Brasília: Ministério da Saúde, 2004.

.. Lei ${ }^{\circ}$. 10.708, de 31 de Julho de 2003. Institui o auxílio-reabilitação psicossocial para pacientes acometidos de transtornos mentais egressos de internações. Diário Oficial da República Federativa do Brasil, Poder Executivo. Brasília (DF), 01 ago. 2003.

.. Ministério da Saúde. Relatório Final da III Conferência Nacional de Saúde Mental. Brasília: Ministério da Saúde, 2002.

Lei de n. 10.216, de 06 abr. 2001. Dispõe sobre a proteção e os direitos das pessoas portadoras de transtornos mentais e redireciona o modelo assistencial em saúde mental. Diário Oficial da República Federativa do Brasil, Poder Executivo. Brasília (DF), 9 abr. 2001.

Portaria 106/2000 GM, de 11 fev. 2000. Institui os Serviços Residenciais Terapêuticos. Diário Oficial da República Federativa do Brasil, Poder Executivo. Brasília (DF), 21 fev. 2000a.

BRASIL. Ministério da Saúde. Programa Saúde da Família. Rev. Saúde pública, v. 34, n.3, p. 316-319, $2000 \mathrm{~b}$. 
294 | Residências Terapêuticas

COLVERO, L. A.; OLIVEIRA, M. A. F. A saúde mental no programa de saúde da família. In: Manual de enfermagem - Programa de saúde da família. São Paulo: USP, 2001.

DEL-BEM, C. M. et al. Políticas de saúde mental e mudanças na demanda de serviços de emergência. Rev. Saúde Pública, v. 33, n. 5, p. 470-476, 1999.

FOUCAULT, M. A História da Loucura. São Paulo: Editora Universitária, 1995.

GONÇALVES, A. M.; SENA, R. R. A reforma psiquiátrica no Brasil: contextualização e reflexos sobre o cuidado com o doente mental na família. Rev. Latino-Am. Enferm, v. 9, n. 2, p. 48-55, 2001. Disponível em: <http://www.revistasusp.sibi.usp.br/scielo.php?script=sci_ arttext\&pid=S0104-11692001000200007\&lng=pt $>$. Acessado em: 09 jun. 2009.

GONÇALVES, C. C. O Grito das Mulheres foi Ouvido: a experiência do grupo de saúde mental da equipe amarela do bairro do Pedregal Campina Grande, PB. 2005. Dissertação (Mestrado em Saúde Coletiva). Centro de Pós-Graduação - Universidade Estadual da Paraíba. Campina Grande, 2005.

LEITE, L. S.; OLIVEIRA, M. A. P. O trabalho da Equipe Itinerante nos processos de inclusão social de portadores de sofrimento psíquico. Divug. Saúde Debate, v. 36, p. 53-60, 2006.

OMS. Relatório sobre a Saúde no Mundo. Saúde Mental: nova concepção, nova esperança. Lisboa: OPA, 2001.

PARAÍBA. Norma Operacional de Assistência a saúde - NOAS SUS. Instrução normativa $n^{\circ} 1 / 2001$. Instrução normativa $n^{\circ} 2 / 2001$. João Pessoa: Núcleo técnico de planejamento, 2001. 
TROVÃO, A. L. C. "É como se fosse uma caverna escura”: representações sociais sobre saúde mental elaboradas por profissionais do PSF, Boqueirão - PB. 2003. Dissertação (Mestrado em Saúde Coletiva). Centro de Pós-Graduação - Universidade Estadual da Paraíba. Campina Grande, 2003.

VECCHIA, M. D. A saúde mental no programa de saúde da família: estudo sobre práticas e significações de uma equipe. 2006. 107f. Dissertação (Mestrado em Saúde Coletiva). Faculdade de Medicina de Botucatu - Universidade Estadual Paulista. Botucatu, 2006. 



\title{
Casa, uma casa, minha casa: cartografia afetiva do morar
}

\author{
Mahayana Nava de Paiva Gaudêncio \\ Edmundo de Oliveira Gaudêncio
}

\section{Introdução}

A casa representada numa estampa suscita facilmente o desejo de habitá-la. Sentimos que gostaríamos de lá viver, entre os próprios traços do desenho bem impresso. A quimera que nos impele a viver nos cantos nasce também, às vezes, pelo encanto de um simples desenho (BACHELARD, 1978).

Este trabalho, na verdade uma "bricollage" de imagens afetivas, resulta do cruzamento dos olhares de uma estudante de Arquitetura e um estudioso de Sociologia, enquanto obedece ao modelo de uma "poética do espaço", tal como proposto por Gaston Bachelard, que tomamos como fio de prumo.

Diz ele:

Os conceitos são gavetas que servem para classificar os conhecimentos; os conceitos são termos de confecção que desindividualizam 
os conhecimentos vividos. Para cada conceito há uma gaveta no móvel das categorias. O conceito é um pensamento morto, já que ele é, por definição, pensamento classificado (BACHELARD, 1978).

Afirma ainda: "só as imagens podem recolocar os verbos em movimento" e "pelos poemas, talvez mais do que pelas lembranças, tocamos o fundo poético do espaço da casa" (BACHELARD, 1978).

Daí a forma deste trabalho, mais afetiva que racional, mais imagética que conceitual, na verdade recortes, flashes, mas também mosaico, fractal, rizoma. Em suma, uma leitura bachelardiana sobre o imaginário despertado pelas emoções derivadas das imagens afetivas e mnésticas geradas pela casa. Objetivando cartografar a morada do ser humano, tomemos o percurso que nos é sugerido pelo conceito de "casa", em seguida, tomemos a noção de "uma casa", e por fim, tomemos a ideia de "minha casa".

De saída, essas três concepções nos apontam que uma casa é uma casa, mas uma casa é sempre diferente: não há no mundo duas casas idênticas e até a mesma casa todos os dias é sempre uma casa nova, porque sempre novos, sempre outros, a cada dia, são os seus velhos habitantes.

Mas, casa, em linhas gerais, é moradia, habitação, morada, residência. Casa é também casebre, choça, choupana, palhoça, mansão, apê, palácio. Casa é toca, ninho, concha, covil, exemplos da diversidade do que seja casa, abrigo, guarida, acolhimento, recolhimento, cumprindo com tudo isso a mesma função de proteção contra a natureza. Com a palavra, Bachelard (1978): "se nos perguntassem qual o benefício mais precioso da casa, diríamos: a casa abriga o devaneio, a casa protege o sonhador, a casa nos permite sonhar em paz". E prossegue, na mesma página: “A casa, na vida do homem, afasta contingências, multiplica seus conselhos de continuidade. Sem ela, o homem seria um ser disperso. Ela mantém o homem através das 
tempestades do céu e das tempestades da vida. Ela é corpo e alma. É o primeiro mundo do ser humano. Antes de ser 'atirado ao mundo', como o professam os metafísicos apressados, o homem é colocado no berço da casa. E sempre, em nossos devaneios, a casa é um grande berço. (...) A vida começa bem; começa fechada, protegida, agasalhada no seio da casa". Mas, se tudo isso é casa, o que é casa para o animal humano?

Para quem nasceu na língua portuguesa, são diversos os sinônimos de casa. Perseguimos o conceito disso, na trama que os vocábulos costuram no dicionário: Segundo Houaiss e Villar (2001), morada é "1. Casa ou lugar em que se habita; moradia, moradio. 2. Período em que se permanece domiciliado em algum local; permanência.3. $O$ endereço de residência. 4. Local onde se encontra habitualmente determinada coisa. Última morada, 1. O cemitério. 2. O túmulo, a sepultura."

Por outro lado, estabelecendo interfaces com morada, moradia é "1. Morada ('Casa'). 2. Tença concedida a fidalgos e a funcionários públicos para suprir despesas com habitação. 3 - Licença concedida a um religioso para que obtivesse sustento também fora do seu convento." De outra forma, residência é "1. Hospedaria mais luxuosa que a pensão, mas menos aparelhada que o hotel. 3. Morada habitual em determinado lugar. 4. Permanência obrigatória no lugar em que se exerce uma função. 5. Casa de habitação, domicílio, lar, morada. 6. Local onde alguém fixa sua habitação durante determinado período." Casa, por fim, é "1. Edifício de formatos e tamanhos variados, geralmente de um ou dois andares, quase sempre destinado à habitação. 2. Cada uma das dependências em que é dividida uma habitação. 3. Família; lar. 7. O conjunto de negócios e assuntos domésticos. 8. Mobiliário, roupas, louças e demais objetos que são necessários a uma residência. 9. Lugar destinado a encontros, a reuniões ou à moradia de certas categorias de pessoas, cujos interesses, origens e culturas por vezes representa ou expressa. 10. Estabelecimento ou firma comercial" (HOUAISS; VILLAR, 2001). 
Nessa trama conceitual, cabe a pergunta: o que compõe uma casa?

Casa é aquilo de que é feita uma casa. De taipa, de adobe, de tijolo, de pedra, de concreto, de aço, de gelo, de vidro, de galhos, de madeira, de papelão - o que não é casa, ainda assim pode vir a servir de arremedo de moradia. Diógenes, aliás, não transformou um grande odre de barro em residência?

Uma casa é também a soma dos componentes arquitetônicos que geralmente estruturam uma casa mediana: Jardins, varandas, terraço, sala-de-visitas, sala-de-estar, sala-de-jantar, quartos, banheiros, cozinha, quintal, às vezes porão e sótão - os quais, quando presentes, atestam melhor que ninguém a "verticalidade do ser da casa", verticalidade que é assegurada pela polaridade do porão e do sótão: "No sótão, a experiência do dia que pode sempre apagar os medos da noite. No porão há escuridão dia e noite. Mesmo com uma vela na mão, o homem vê as sombras dançarem na muralha negra do porão" (BACHELARD, 1978).

Evidentemente, uma casa típica é também portões, portas, janelas - e não disse Bachelard (1978) "a lâmpada à janela é o olho da casa."? E não falou, ainda, que "Há casas claras onde mora, em todas as estações do ano, o verão. São só de janelas"?. Entretanto quer seja a casa rural, seja a casa urbana; seja a casa construída em série, seja a casa artesanal dos ladrilhos do piso, passando pelos tijolos das paredes, às telhas do teto, esse o espaço da casa, apesar de que frequentes vezes a casa se reduz a um cômodo de palha ou de adobe, da qual dizem as muitas pessoas que a dividem: "Esta é minha casa. Seja bem-vindo...!"

Além disso, a casa é espaço privado recortado do espaço público: a casa e a rua; o dentro e o fora; o interno, o privado, o íntimo. Uma casa é ponto de referência espacial: imobilidade em meio aos deslocamentos do sair de ou do voltar para casa. Casa é ponto de referência afetivo: estar e ficar em si mesmo exatamente por poder 
estar e ficar em casa. Casa é lugar de pertença, presença, às vezes nascença e morte. Diz Bachelard (1978), citando Supervielle, que à "vertigem do exterior" se contrapõe uma "imensidão interior", vez que, como ele havia dito, "a casa é nosso canto no mundo". Casa é ponto de referência para a cidadania: não ter endereço fixo é condição impeditiva para o habeas corpus, para o "tenhas o corpo" que é garantia do direito de ir e vir.

$\mathrm{Na}$ caracterização da casa, adiciona-se a tudo isso a história vez que a casa é a história que o tempo conta sobre o que foi, o que é, o que será uma casa. Assim, a cada tempo e cada lugar, cada casa de cada um que se expressa nos estilos arquitetônicos e no estilo pessoal de seus habitantes. Diz-me como é a casa e te direi como são os seus habitantes, uma vez que a identidade da casa é - ou deve ser - um reflexo da identidade de seus donos, tomando, a fisionomia da casa, a fisionomia de seus proprietários.

Descrever a fisionomia da casa típica ou da casa que tipifica a morada do homem ao longo da história implica em ter que contar que as casas gregas, assim como nas demais civilizações, foram erguidas mediante os princípios da segregação econômica - exceto aquelas construídas na primeira metade do século $\mathrm{V}$, como afirma Maffre (1989): “As habitações privadas daqueles que estavam então no poder (...) eram tão modestas... que a casa de um Címon, de um Aristide, e em geral, dos homens ilustres daquele tempo, parece, a cada um de vós que a conhece, em nada mais suntuosa que a casa do nosso vizinho". Posterior a essa época, comenta Maffre: “Em cidades grandes e antigas, como Atenas, há todo o tipo de casas, de acordo com os bairros e o grau de fortuna dos ocupantes”. Assim sendo, era comum construir na Grécia Clássica, com madeira, pedra, tijolo cru, adobe, barro ou "com uma massa de palha e lama, segundo a expressão de Aristóteles” (MAFFRE, 1989). A qualidade dos cômodos assim como a quantidade, também, advêm das condições socioeconômicas: "nos bairros populares amontoam-se casinhas que se limitam raramente a um cômodo, mas têm dois ou três no 
térreo, com às vezes, um ou dois quartos minúsculos no andar, aos quais dá acesso uma escada exterior de madeira que acaba em uma sacada que sobressai da parede, dando para a rua" (MAFFRE, 1989). Sobre as casas mais suntuosas, continua o autor: "O térreo das casas maiores compreendem, além das salas de estar, o pátio e o vestíbulo, uma sala de recepção reservada aos homens, o andrôn, e cômodos de serviço: cozinha, despensa, e às vezes banheiro, oficina, loja, que se abrem para a rua independentemente. Os aposentos das mulheres (gineceu) e os quartos da criadagem estão no andar" (MAFFRE, 1989).

Características ligadas ao contexto socioeconômico também são observadas na Idade Média, no tocante à divisão/locação territorial das classes sociais. Os raros edifícios públicos dividiam o mesmo espaço com fortalezas, castelos, residências de nobres, ricos burgueses e clérigos com as residências particulares. No entanto, todas essas tipologias da diferente forma de habitar resumem o sentimento e a necessidade de toda uma época: a proteção. $\mathrm{O}$ urbanismo medieval nasce exatamente dessa necessidade de proteção e defesa, assim como afirma Giordani (GIORDANI, 1983): "quando as necessidades de defesa levaram à fundação de cidades em locais que facilitassem repelir ataques ou enfrentar assédios (colinas, ilhas, confluências de rios etc.), a fisionomia urbana refletia a topografia irregular a que estavam sujeitos os traçados das ruas." Giordani continua, a mesma página: "Na Idade Média predomina a cidade irregular, o que se explica por seu crescimento orgânico e natural. Irregular aqui não significa existência de caos".

É dentro desse contexto de irregularidade e necessidade de proteção que a vida cotidiana acontece e nos apresenta seu melhor objeto: o lar. As diferentes classes sociais existentes nos permitem observar as casas sob tipologias diversas. Sobre as casas rurais, Giordani (1983) diz: "Esta compunha-se, geralmente, de uma única sala onde se desenrolavam todas as atividades do lar: Aí se comia e convivia, aí repousavam mulheres e crianças, já que aos homens bastava o 
palheiro instalado por cima dos estábulos. É claro que esta 'casa' podia comportar maior número de divisões, consoante a abastança do proprietário". O autor, acerca da casa urbana e seus cômodos, descreve: "ao lado do edifício residencial existiam, conforme a situação econômica do proprietário, outras edificações: a adega para o vinho, o celeiro, os abrigos para os veículos, os estábulos etc." Em contraponto a vida simples dos camponeses, Giordani (1983) faz a descrição de um castelo dizendo que

as muralhas dos castelos abrigavam armazéns, estábulos, padaria, alojamento para serviçais e também uma capela. (...) O pavimento inferior funcionava como depósito e calabouço. (...) No segundo pavimento ficava o salão principal, que servia de corte de justiça ao barão e de sala de jantar, de estar e quarto de dormir para a maior parte da família. (GIORDANI 1983).

Na Idade Média, a matéria prima das construções diverge também de acordo com as condições econômicas. Sobre isso, relata Giordani (1983) ainda: "Durante muito tempo as casas das cidades parecem ter sido construídas de madeira ou terra socada. Por volta do início do século XII aparece a casa de pedra." - e se fôssemos contar a história da casa de tijolo teríamos toda uma enorme obra pela frente, só para contar a história do tijolo, só para falar do tijolo na História, o que, evidentemente, não cabe nos limites deste trabalho.

Por outro lado, com o advento da modernidade, novas concepções para a casa, uma vez que a cidade se torna objetivo de vida, sofrendo, a cidade, constantes mutações oriundas desse novo ser urbano, a ponto de Baudelaire dizer que "a forma de uma cidade muda mais rápido, infelizmente, do que o coração de um mortal.” Na cidade moderna, o barro, o adobe, a pedra ficam restritos às classes mais pobres, quando não são descartados por completo. Sobre isso comenta Benévolo (1976): “As moradias tornam-se mais higiênicas 
graças à substituição da madeira e da palha por materiais mais duráveis, e ainda mais pela separação ente casa e oficina". De fato, esse rompimento com o tradicional mostrou-se necessário quando analisado sob a ótica da qualidade de vida. A modernidade dita a moda, que muitas vezes é entendida como o ápice da construção, sendo por vezes ignorados os aspectos de conforto, cultura e história de uma localidade e sua civilização. Mas, dessas construções bem ou mal sucedidas é que resultam hoje as nossas casas de ferro, de aço, de vidro, de formas e texturas que permitem uma melhor representação de quem as habita. Dessa modernidade, é que também surgem as diversas variações do lar: o albergue, o flat, as casas terapêuticas, formas que permitem o ser e o estar de um indivíduo, como afirma Botton (2007): "Em troca, tendemos a honrar aqueles lugares cuja perspectiva combina com a nossa e a legitimiza chamando-os de 'lar'. Nossos lares não precisam nos oferecer abrigo permanente ou guardar as nossas roupas para que mereçam esse nome. Falar em lar com relação a uma construção é simplesmente reconhecer a sua harmonia com a nossa própria canção interior preferida. Lar pode ser um aeroporto ou uma biblioteca, um jardim ou um trailer de comida na beira da estrada.".

$\mathrm{Na}$ atualidade, a casa é verticalizada, os espaços são em geral reduzidos, mas a casa continua presente, constante e fundamental: "Precisamos de um lar no sentido psicológico tanto quanto no físico: para compensar uma vulnerabilidade. Precisamos de um refúgio para proteger nossos estados mentais, porque o mundo em grande parte se opõe às nossas convicções" (BOTTON, 2007).

Como fica evidente, a cada tempo e lugar, os condicionantes históricos, econômicos, sociais, políticos, culturais, estéticos da casa e dos estilos de morar, como se pode depreender de Certeau (1996). Em cada época e em cada estilo, a pessoalidade do estar morando, do habitar e do habitat, vez que as casas, em geral, arrumam-se sob a forma de ruas, uma casa interagindo com outras tantas casas, no melhor sentido do vocábulo Ecologia. 
Mas se isso se pode dizer sobre o que seja o conceito de "casa", a que corresponde a noção de "uma casa"? Falar do conceito impessoal de casa não significa apreender a noção individualizada de "uma casa". E o que faz "uma casa"? O que faz uma casa, uma determinada casa, não é apenas piso, paredes, teto. O que faz uma casa é a dinâmica da casa, é a circulação de pessoas e coisas e bens e valores: o ir e vir de passadas e passados, a chegada de visitas, a partida de parentes, o dia a dia das presenças e gestos que vão preenchendo as salas, os quartos, todos os cômodos da casa. Pensar "uma casa" significa pensar a casa no tempo e os tempos da casa, significa pensar a casa de ausências e presenças. Falar sobre uma casa no tempo significa ter que dizer dos estilos de morar, sempre diferentes, a cada tempo, compare-se, por exemplo, o morar moderno em apartamentos com o morar dos gregos e romanos, os quais passavam a maior parte do dia fora de casa.

De outro modo, sobre os tempos de uma casa, havemos que referir o contraste entre uma casa nova, cheirando a tinta fresca e ainda sem história e a casa natal, casa a que prototipicamente retornamos, toda a vez em que voltamos para casa, o que leva Bachelard a dizer: "Habitar oniricamente a casa natal é mais que habitá-la pela lembrança, é viver na casa desaparecida como nós sonhamos" (BACHELARD, 1978).

Pensar uma casa, porém, implica também em pensar uma casa no espaço e nos espaços de uma casa. Sobre tal questão, afirma Bachelard (1978): "a casa é um corpo de imagens que dão ao homem razões ou ilusões de estabilidade. Reimaginamos constantemente sua realidade: distinguir todas as imagens seria revelar a alma da casa; seria desenvolver uma verdadeira psicologia da casa", casa que é imaginada como um "ser vertical" e "como um ser concentrado", esse ser concentrado que localizamos no espaço através do que se denomina endereço, o que, para Houaiss e Villar (2001), é 1. Conjunto de dados (nome de rua, número de casa, prédio ou terreno, etc.) que torna possível a localização de um imóvel e/ou designam 
o próprio imóvel. 2. Inscrição do nome e residência em sobrecarta, bilhete etc.; sobrescrito. Dito de forma figurada, endereço, em suma, é a nomeação pública de nosso lugar, ponto em que, na trama anônima da cidade, podemos ser localizados, nosso canto.

No tocante aos espaços de uma casa, uma obviedade: à casa se contrapõe a rua. A rua é o espaço público, e público, dizem Houaiss e Villar (2001), é aquilo que é 1. Relativo ou pertencente a um povo, a uma coletividade. 2. Relativo ou pertencente ao governo de um país, estado, cidade, etc. 3. Que pertence a todos; comum. 4. Que é aberto a quaisquer pessoas. Ou seja, enquanto espaço público, a rua é um lugar de todo mundo, porquanto a casa é um lugar privativo, o canto de cada um. Afirmam Houaiss e Villar (2001), sobre o que é coisa privada, quanto aos sinônimos que nos interessam: 3. Que pertence a um indivíduo particular. 4. Restrito, reservado a quem de direito; confidencial. 5. Que é pessoal e não expresso em público. 7. Afastado do conhecimento público; secreto. 9. Sem presenças alheias; só, solitário, isolado. 11. Pertencente a cada individuo; particular, próprio, individual.

Assim, fora da casa é o imprevisto, o acaso, a desproteção, o desvalimento. Dentro da casa, é o aconchego, a fraternidade, a união - pelo menos como ideal, vez que a casa é o ninho do homem.

A esses dois usos sociais do espaço, o público e o privado (HALL, 2005), este último sendo melhor inventado a partir dos séculos XVII-XVIII, soma-se um terceiro, visibilizado a partir do conceito de intimidade.

O íntimo, dizem Houaiss e Villar (2001) é 1. Relativo a quem constitui a essência, o cerne de algo. 2. Quem tem origem ou que existe no âmago de uma pessoa. 3. Que diz respeito ao que se passa nos recônditos da mente, do espírito. 4. A quem se é estreitamente ligado por laços de afeição e amizade. 9. Que trata de assuntos extremamente pessoais e confidenciais; particular, privado. 11. Cujo ambiente é propício a que se tenha privacidade, tranquilidade e aconchego. 
O espaço íntimo, bem se percebe, é um recorte mais pessoal na privacidade do que é privativo. Exemplos de espaços íntimos, na casa, em nome do pudor e do decoro, como aponta Bologne (1990), são a alcova e sobretudo a privada - que de um certo modo era pública, quando até finais do século XVIII.

Esse espaço da mais total privacidade se diz respeito aos segredos sexuais do cálamo e da internidade das vísceras, diz respeito, também, à projeção do dono da intimidade para as coisas da casa onde guarde seus segredos, o cofre, a bolsa, a carteira, mas também as gavetas, os guarda-roupas, as agendas e objetos de uso pessoal. E somente a casa pode possibilitar, de forma duradoura, essa intimidade, cuja máxima expressão é a fechadura, da qual afirma Bachelard (1978): “que umbral psicológico é uma fechadura!"

Por outro lado, descrever os cômodos da casa é coisa simples, embora, como salienta Bachelard (1978), "as coisas simples são muitas vezes psicologicamente complexas." Sumariamente podemos dizer que salas, quartos, cozinhas, banheiros, são esses, geralmente, os cantos da casa, as partes que dão sentido ao todo que é uma casa.

Mas se uma casa é o sentido da casa, uma casa é também uma casa para os sentidos, sobretudo a visão, a escuta, o olfato. De um lado, existem os claros e escuros de uma casa, vez que se há de convir que uma coisa é casa vestida de luz, para as festas, outra é uma casa à luz de velas ou uma casa às escuras, embora a luz e a escuridão sejam ambos constituintes inequívocas de uma casa, sobretudo se considerando o porão sempre à sombra, dentro da terra, o sótão que se abre para a luz, projetando-se para as nuvens.

Se assim o é para a visão, depois é barulho de festa, são risos, murmúrios, cochichos, gemidos que ecoam do piso, do teto, das paredes, os quais melhor percebemos quando, por exemplo, uma vez adultos, voltamos à casa da infância e só então nos damos conta do eco do tempo nos retratos dos parentes mortos a nos espiarem, em silêncio, das paredes onde se acham dependurados por um fio 
desde sempre, a casa contida no tempo se confundido com o tempo contido na casa, contados os silêncios de uma casa na casa cantada pelo tempo da memória. Afirma Bachelard (1978): "para quem sabe escutar a casa do passado, não será ela uma geometria de ecos? (...) As vozes, a voz do passado ressoa de forma diferente num cômodo grande e num pequeno quarto". Mas, evidentemente, os silêncios de uma casa tanto dizem de uma casa em silêncio quanto falam de uma casa silenciada. O que, evidentemente, não é uma mesma coisa. Uma casa em silêncio quase sempre é uma casa em paz, uma casa que repousa. Uma casa silenciada, casa onde não se fala e muito menos se canta, é casa amordaçada - e sabe lá quem adiante dela passa qual seja o motivo de tanto silêncio...!

Mas se isso se dá ou não se dá aos ouvidos, o que dizer dos cheiros de uma casa? O cheiro de uma casa é sempre único. Cada casa tem aroma próprio, cada cômodo seu odor apropriado. O cheiro de pão, na cozinha; o cheiro de visitantes, na sala de visitas; o cheiro de hospitalidade, na sala de estar; nos quartos de dormir, o cheiro de cumplicidade, de prazer, de sofrimento ou solidão, ou, quem sabe, o cheiro de doença e o cheiro de morte.

Ocorre, entretanto, que dizer da noção de uma casa não significa falar da ideia de "minha casa". Falar "minha casa" é diferente de dizer "uma casa" - o que difere, por sua vez, do conceito de "casa". Proferir a sentença "minha casa" tanto remete à casa própria quanto à própria casa, no que ela difere entre moradia e lar, coisas afetivamente diferentes, pois moradia é o lugar onde se mora, apenas, enquanto lar é o lugar em que geralmente se vive com a família, núcleo da coabitação afetiva e efetiva. Sobre lar, dizem Houaiss e Villar (2001): 2. A casa de habitação; domicílio familiar. 3. Grupo de pessoas vivendo sob o mesmo teto; família. 4. A pátria, a terra natal. 6. Ninho de aves ou covil de animal. 7. Entre os etruscos e os antigos romanos, deuses domésticos, protetores da família e da casa.

Talvez o lar seja melhor caracterizado quando se tem em mente a casa da infância. Sobre ela, conta Bachelard (1978): "Tudo o que 
devo dizer da casa da minha infância é justamente o que me é necessário para me colocar numa situação de onirismo, para me colocar no bojo de um devaneio em que vou repousar no meu passado". Afirma ele, ainda, mais adiante: "A casa natal, mais que um protótipo de casa, é um corpo de sonhos”

Lar é casa natal, seja uma choupana, seja um castelo. Aliás, diz Bachelard (1978), citando George Sand, diz que "se podem classificar os homens segundo queiram viver numa choupana ou num palácio. Mas a questão é mais complexa: quem tem um palácio sonha com uma choupana, quem tem uma choupana sonha com um palácio. Melhor, cada um de nós tem suas horas de choupana e suas horas de palácio."

Em um caso e noutro, o que interessa é que a moradia, para ser lar, tem que ser como mãe que acolhe, tem que existir, na casa, uma casa de braços abertos, pois não nos fala Bachelard (1978) da "maternidade da casa"?

Pois bem, a casa própria é sonho: possuir um teto que nos projeta, ser proprietário do chão em que se pisa, poder deixar por herança todo o tempo de uma existência transcorrido entre paredes. Mas se a casa própria é sonho, a própria casa pode ser motivo de devaneio, quando, por exemplo, pensamos nas entranhas de nossa casa, em seus intestinos de canos hidráulicos, em suas fiações elétrico-nervosas, em seu esqueleto de ferro, em suas carnes de tijolos e em sua pele de argamassa. E só nós sabemos das doenças de nossa casa: cupins, moscas, baratas, ratos, teias de aranha, uma torneira que pinga, uma lâmpada que não acende, males, aliás, de que padecem os melhores lares.

Por isso tudo, a casa da infância é o ninho primordial e o ninho, para Bachelard (1978), "o ninho é um ramo de folhas que canta", sendo "o mundo o ninho do homem".

Mas como ninhos, os lares às vezes se desfazem, quando os laços afetivos se rompem, quando as relações cotidianas se esgarçam. Em tal situação, as pessoas se perdem de casa e a casa se perde 
enquanto ponto de referência. Aliás, toda a vez em que uma casa se perde, seja essa perda consequência de intempérie, seja por motivo de exílio, por exemplo, toda a vez que uma casa se perde, repetimos, não só nos perdemos na casa, somos nós que nós perdemos de nós mesmos. Por isso, o que dizer desses que são sem-teto, esses que, "fora do ser da casa, [enfrentam a] circunstância em que [se] acumulam a hostilidade dos homens e a hostilidade do universo"? (BACHELARD, 1978).

Por outro lado, se o lar pode ser entediante para quem, por doença ou por determinação legal, não pode sair de casa, quanto prazer é poder construir uma moradia, quanta alegria é poder voltar à morada, quanta felicidade é poder ser aceito como morador, seja de um albergue, de uma pousada, de uma residência terapêutica, isso que tem por função dar um endereço, permitindo a cidadania; possibilitar um centro, um canto a uma pessoa sem família, permitindo abrigo e aconchego. Afinal, é a hospitalidade que transforma o inimigo (hostis) em hóspede (hospis), como se pode deduzir a partir da ideia proposta por Derrida (2003) e confirmada em Houaiss e Villar (2001). Tudo isso porque um sujeito sem casa é um sujeito sem centro - e um sujeito sem centro será um sujeito?

Entretanto, somente porque temos um teto, quase sempre nos esquecemos de reverenciar os lares, fazendo-lhes votos e lhes acendendo velas. E nos pomos em dilema: se dentro do lar é segurança contra o mundo, é o mundo e seus perigos lá fora nos chamando... Ir ou não ir? Ficar ou partir? Poder, querer, dever ficar; dever, querer, poder partir; querer, poder, dever voltar. Querer ficar, mas ter de partir. Não poder partir, ter de ficar. Dever ou não dever, quer ficar, quer partir, quer voltar, são muitos os dilemas colocados entre a minha casa no mundo e o mundo da minha casa. Nisso tudo, no que tange à minha morada, a quantos metros, para baixo, os muros de minha casa se projetam? Ou seja, quanto se projeta, terra a dentro, o meu direito de posse sobre o terreno em que se ergue minha casa? E quanto do céu acima me pertence, se sou dono da terra onde 
edifiquei minha morada, cujos muros para o alto se arremetem? Com isso concorda Bachelard (1978), dizendo de sua casa: "Suas paredes se condensam e expandem segundo meu desejo. Às vezes aperto-as contra mim, como uma armadura de isolamento... mas, às vezes, deixo as paredes de minha casa se expandirem em seu próprio espaço, que é de extensibilidade infinita". Pensamos nisso, enquanto a casa embala nossos sonhos noite adentro e somente sabemos, em todo caso, que, quando em viagem, partimos de casa, mas é para o lar que voltamos. Quando partimos, é sempre saudade de casa; quando voltamos, é sempre e sempre a velha casa que é sempre a mesma, sendo sempre uma casa nova, diferente, pois ninguém entra o mesmo duas vezes numa mesma casa.

\section{Referências}

BACHELARD, G. A poética do espaço. São Paulo: Abril Cultural, 1978.

BENEVOLO, L. História da arquitetura moderna. São Paulo:

Perspectiva, 1976.

BOLOGNE, J. C. História do pudor. Rio de Janeiro: Elfos, 1990.

BOTTON, A. A arquitetura da felicidade. Rio de Janeiro: Rocco, 2007.

CERTEAU, M. A invenção do cotidiano. Petrópolis: Vozes, 1996.

DERRIDA, J. Anne Dufourmantelle Convida Jacques Derrida a Falar da Hospitalidade. São Paulo: Escuta, 2003.

GIORDANI, M. C. História do mundo feudal. Vol. II. Petrópolis: Vozes, 1983. 
312 | Residências Terapêuticas

HALL, E.T. A dimensão oculta. São Paulo: Martins Fontes, 2005.

HOUAISS, A.; VILLAR, M.S. Dicionário Houaiss da Língua Portuguesa. Rio de Janeiro: Objetiva, 2001.

MAFFRE, J. J. A vida na Grécia clássica. Rio de Janeiro: Jorge Zahar, 1989. 


\section{Organizadores}

\section{Maria de Fátima de Araújo Silveira}

Enfermeira. Doutora em Enfermagem, USP. Professora Titular do Departamento de Enfermagem da Universidade Estadual da Paraíba/UEPB.

\section{Hudson Pires de Oliveira Santos Junior}

Enfermeiro. Doutorando. Discente do Programa Interunidades de Doutoramento em Enfermagem da Escola de Enfermagem da Universidade de São Paulo/EE-USP. Bolsista FAPESP. 


\section{Colaboradores}

\section{Alan Jorge}

Enfermeiro. Residência Integrada em Saúde Mental Coletiva EDUCASAÚDE-FACED-UFRGS.

\section{Ana Angélica Pereira Souza}

Graduanda do curso de Psicologia da Universidade Estadual da Paraíba/UEPB. Bolsista PIBIC/CNPq.

\section{Andrea Abreu Calista}

Graduanda do curso de enfermagem da Faculdade de Ciências Médicas de Campina Grande.

\section{Ariedney Sâmylla de Souza Vasconcelos}

Enfermeira assistencial da Emergência Psiquiátrica de Campina Grande-PB.

\section{Chirlaine Cristine Gonçalves}

Enfermeira. Mestra em Saúde Coletiva, UEPB. Professora da Faculdade de Ciências Médicas de Campina Grande.

\section{Cínthia Jaqueline Rodrigues Bezerra Galiza}

Psicóloga. Assessora Técnica da Coordenação de Saúde Mental da Secretaria Municipal de Saúde de João Pessoa. 


\section{Cláudia Santos Martiniano}

Enfermeira. Mestra em Saúde Coletiva, UEPB. Professora Titular do Departamento de Enfermagem da Universidade Estadual da Paraíba/UEPB.

\section{Dulce Maria Rosa Gualda}

Obstetriz. Livre-Docente. Professora Titular do Departamento materno-infantil da Escola de Enfermagem da Universidade de São Paulo/EE-USP.

\section{Edmundo de Oliveira Gaudêncio}

Médico-psiquiatra. Doutor em Sociologia. Professor Titular da Universidade Federal de Campina Grande e da Universidade Estadual da Paraíba.

\section{Élida Dantas do Nascimento}

Graduanda do curso de Psicologia da Universidade Estadual da Paraíba/UEPB.

\section{Florianita Coelho Braga-Campos}

Professora Adjunta, Universidade Federal de São Paulo, Campus Baixada Santista. Membro do Grupo de pesquisa LAPS.

\section{Gabriel Binkowski}

Psicólogo. Residência Integrada em Saúde Mental Coletiva EDUCASAÚDE-FACED-UFRGS.

\section{Ivoneide Lucena Pereira}

Psicóloga e Gerente Administrativa Clínica-Escola/FCM. 


\section{Jaqueline Queiroz de Macedo}

Enfermeira. Mestranda do Programa de Pós-Graduação da Universidade Federal do Ceará/UFC.

\section{Juarez Pereira Furtado}

Professor Adjunto, Universidade Federal de São Paulo, Campus Baixada Santista. Doutor em Saúde Coletiva, Unicamp/ Umontreal.

\section{Lia Braga}

Artista Plástica. Residência Integrada em Saúde Mental Coletiva EDUCASAÚDE-FACED-UFRGS.

\section{Mahayana Nava de Paiva Gaudêncio}

Graduanda do Curso de Arquitetura da Faculdade de Ciências Sociais Aplicadas, Campina Grande, PB.

\section{Maria Cidney da Silva Soares}

Enfermeira. Mestranda do Programa de Pós-Graduação da Universidade Federal da Paraíba/UFPB.

\section{Maria de Fátima Moura Feitosa}

Psicóloga do CAPS Gutemberg Botelho do Município de João Pessoa.

\section{Maria do Carmo Eulálio}

Psicóloga. Doutorado em Psicopatologia Clínica, Université Paul Valéry, França. Professora Titular do Departamento de Psicologia da Universidade Estadual da Paraíba/UEPB. 


\section{Mércia Maria de Paiva Gaudêncio}

Enfermeira. Psicóloga. Mestra em Saúde Coletiva. Professora Titular do Departamento de Enfermagem da Universidade Estadual da Paraíba/UEPB.

\section{Mércia Maria dos Santos}

Psicóloga e Diretora de Regulação da Secretaria Municipal de Saúde de João Pessoa.

\section{Nádia Geisa de Souza}

Professora Programa de Pós Graduação Faculdade de Educação UFRGS.

\section{Natália Regina Salim}

Obstetriz. Doutoranda. Discente do Programa Interunidades de Doutoramento em Enfermagem da Escola de Enfermagem da Universidade de São Paulo/EE-USP.

\section{Pauleska Asevedo Nóbrega}

Graduanda do Curso de Graduação em Psicologia da Universidade Estadual da Paraíba/UEPB.

\section{Pedro de Oliveira Filho}

Professor do Departamento de Psicologia e Orientação Educacionais da Universidade Federal de Pernambuco/UFPE.

\section{Rafael Wolski}

Psicólogo. Especialista em Psicologia Social e InstitucionalUFRGS. Coordenador do Residencial Terapêutico Morada Viamão. 


\section{Roseane Barros Pinto}

Graduanda do Curso de Graduação em Psicologia da Universidade Estadual da Paraíba/UEPB.

\section{Simone Chandler Frichembruder}

Psicóloga. Doutorado em Educação, UFRGS. Coordenação Colegiada do Programa de Residência Integrada em Saúde Mental Coletiva Faculdade de Educação.

\section{Stefan Yohansson Gonçalves}

Graduando do curso de medicina da Universidade Federal de Campina Grande. Estagiário da Emergência Psiquiátrica de Campina Grande-PB.

\section{Stelamaris Tinoco}

Fisioterapeuta. Coordenadora do Residencial Terapêutico Morada São Pedro.

\section{Thatianna Lira Silva}

Enfermeira. Graduada pela Universidade Estadual da Paraíba.

\section{Thelma Maria Grisi Velôso}

Psicóloga. Doutora em Sociologia. Professora Titular do Departamento de Psicologia da Universidade Estadual da Paraíba/UEPB.

\section{Vera Resende}

Educadora Física Sanitarista. Coordenadora do Residencial Terapêutico Morada São Pedro. 


\section{Sobre o livro}

Este livro foi impresso na Gráfica Universitária da UEPB.

Formato: $15 \times 21 \mathrm{~cm}$.

Mancha Gráfica: 10,5 x $16 \mathrm{~cm}$.

Tipologias utilizadas: Minion Pro 11/12

Papel: Apergaminhado $75 \mathrm{~g} / \mathrm{m}^{2}$ (miolo) e Cartão Supremo 250g/m² (capa). 